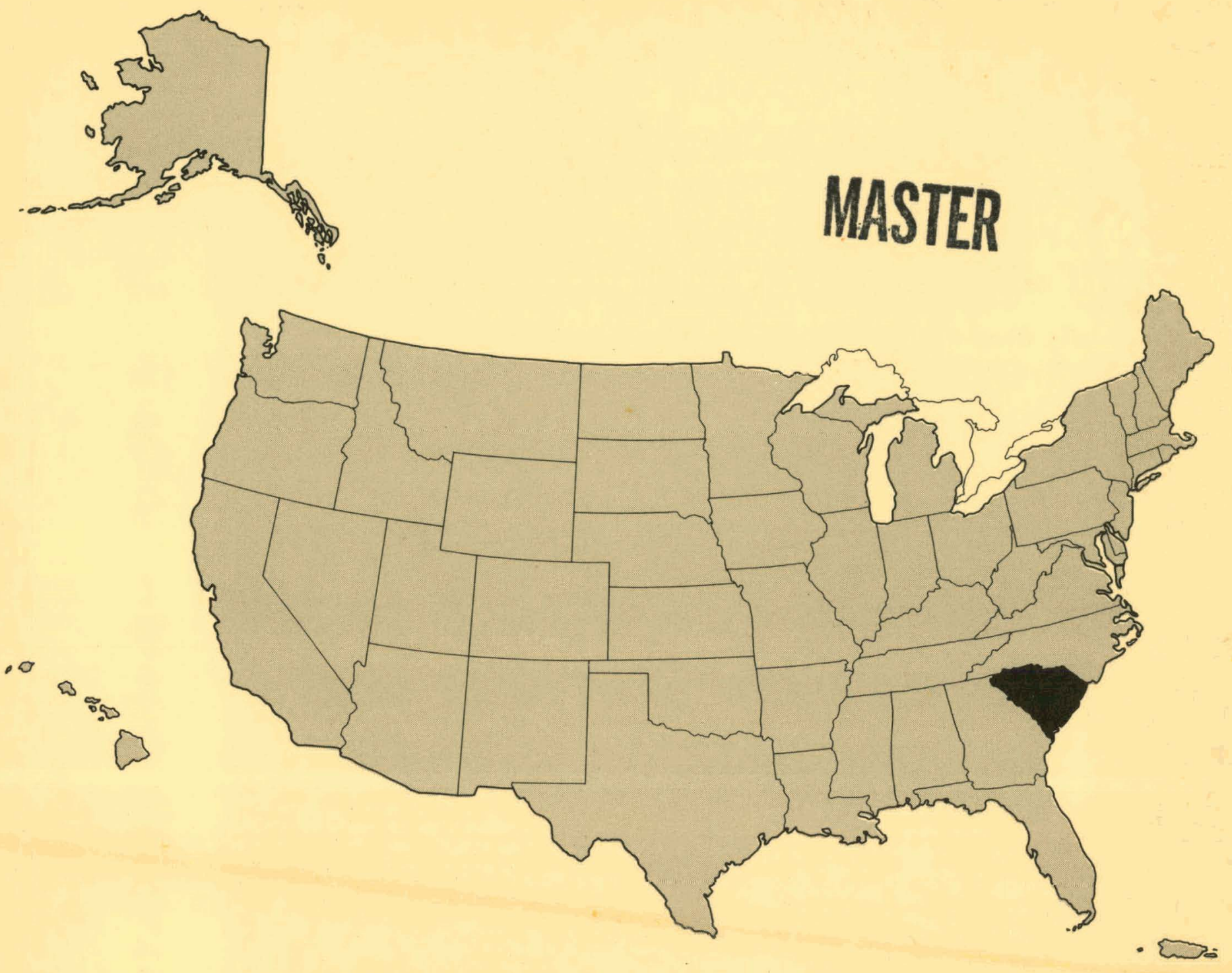

\title{
South Carolina State Briefing Book for Low-Level Radioactive Waste Management
}




\section{DISCLAIMER}

This report was prepared as an account of work sponsored by an agency of the United States Government. Neither the United States Government nor any agency Thereof, nor any of their employees, makes any warranty, express or implied, or assumes any legal liability or responsibility for the accuracy, completeness, or usefulness of any information, apparatus, product, or process disclosed, or represents that its use would not infringe privately owned rights. Reference herein to any specific commercial product, process, or service by trade name, trademark, manufacturer, or otherwise does not necessarily constitute or imply its endorsement, recommendation, or favoring by the United States Government or any agency thereof. The views and opinions of authors expressed herein do not necessarily state or reflect those of the United States Government or any agency thereof. 


\section{DISCLAIMER}

Portions of this document may be illegible in electronic image products. Images are produced from the best available original document. 


\section{The following pages are an exact representation of what is in the original document folder.}




\title{
DOE/ID/01570-.T51
}

\author{
SOUTH CAROLINA STATE BRIEFING BOOK \\ $\rightarrow$ \\ FOR \\ LOW-LEVEL RADIOACTIVELWASTE : MANAGEMENT
}

DOE/ID/01570--T51

DE82 015278

Prepared for

EG\&G Idaho, Inc.

under

Subcontract No. K-1917

Prepared by

Southern States Energy. Board

One Exchange Place, Suite 1230

Atlanta, Ceorgia 30338

August 1981

\section{NOTICE}

I PORTIONS OF THIS REPORT ARE ILLEGIBLE. T\% has been reproduced from the best available copy to permit the broadest possible availability.
This book was prepared as an account of work sponsored by an agency of the United States Government. Neithes the United Stules Government nor any agency thereof. nor any of their emplovees, makes any warranty, express or implied, of assumes any legal hobriv, product, or process disclosed, of completeness, of usefulness of any ihr privety owned rights Reference herein 10 any specific

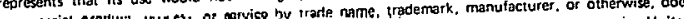
comm Ser the vosoly and opinions of authors expiressed heroin do mot States Government or any agency the United Siates Government or any agency thereol. 
This report was prepared as an account of work sponsored by the United States Government. Neither the United States nor the Department of Energy, nor any of their employees, nor any of their contractors, subcontractors, or their employees, makes any warranty, express or implied," or assumes any legal liability or responsibility for the accuracy, completeness, or usefulness of any information; apparatus, product, or process disclosed or represents that its use would not infringe privately owned rights. 
List of Figures................................

List of Tables............................... vi

L1st of Maps............................... v11

\section{Section}

1. Introduction.............................. 1-1

2. Overview of Low-Level Radloactive Waste

Management Practices......................... 2-1

3. Demography ............................... 3-1

3.1 Population and Location.................... 3-4

3.2 Agrtculture........................... $3-16$

3.3 Health.............................. $3-18$

3.4 Higher Education........................ 3-20

3.5 Government............................. 3-22

3.6 Economy.............................. 3-26

4. Governmental and Public Aspects.................. 4-1

4.1 Major Political Parties..................... 4-1

4.2 South Carolina Delegation.................. 4-1

4.3 State Government........................ 4-3

4.3.1 Execut1ve Branch................... 4-4

4.3 .2 Legislative Branch.................... 4-11

4.3 .3 Judlclal Bínch..................... 4-17

4.3.4 Relevant Statutes and Regulations........ 4-19

4.4 Federal Activities........................ 4-21

4.5 Interest Groups........................... 4-21

4.6 Newspapers............................... 4. 4.24

5. Survey Methodology .......................... 5-1

6. Use of Commercial Low-Level Wásté

Disposal Fac1lities......................... 6-1 
Appendices
A. Annotated B1bllography
B. General Bibllography
C. Selected Newspaper Articles
D. Counties in the State Economic Areas of South Carolina
E. Waste Transportation and Disposal Act
F. Regulations for Radioactive Materials.
G. Interim Regulations for the Transportation of Radioactive Waste Into or Within South Carolina 
3.1.1 Population Data, SEA 1, South Carolina Blue Ridge - Piedmont Transistion....................

3.1.2 Population Data, SEA 2, Northwestern South Carolina Piedmont.............................

3.1.3 Population Data, SEA 3, North Central South Carolina Piedmont...........................6

3.1.4 Population Data, SEA 4, South Carolina Lower Piedmont......3-6

3.1.5 Population Data, SEA 5, South Carolina Sand Hills.........3-7

3.1.6 Population Data, SEA 6, South Carolina Upper Coastal Plain................................

3.1.7 Population Data, SEA 7, Pee Dee River................

3.1.8 Population Data, SEA 8, South Carolina Coast............ 3-8

3.1.A Population Data, SEA A, Columbia SMSA..................

3.1.B Population Data, SEA B, Augusta SMSA (S.C.part)...........

3.1.C Population Data, SEA C, Charleston SMSA................10

3.1.D Population Data, SEA D, Greenville SMSA.............. 3-10

3.1.13 Population Data, State of South Carolina.................11

3.1 Low-level Radioacrlve Waste Survey Form.............5-5

5.2 Vachon, Nix and Associates Survey Letter............

5.3 State of South Carolina Survey Letters...............

5.4 Vachon, Nix and Associates Letter to South Carolina Bureau of Radiological Health................... 5-13

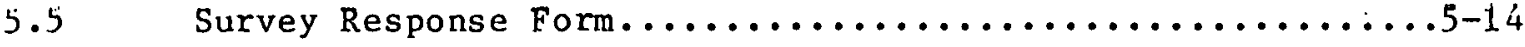




\section{LIST OF TABLES}

Table

$\underline{\text { Page }}$

3.1 Demographic Growth and Density Information for the State of South Carolina and its State Economic Areas.......3-13

3.2 Agricultural Data for the State of South Carolina and its State Economic Areas, 1974 and 1978...............17

3.3 Health Information for the State of South Carolina and its State Economic Areas, 1975......................19

3.4 Information on Institutions of Higher Education for the State of South Carolina and its State Economic Areas:

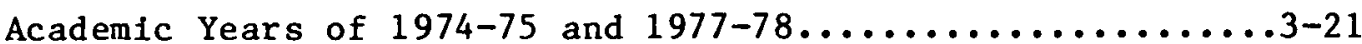

3.5 Government Employment and Payroll Data for the State of South Carolina and its State Economic Areas.......3-23

3.6 Government Finance Data for the State of South Carolina and its State Economic Areas.........................24

3.7 Economic Data for the State of South Carolina............. 3-27

6.1 Respondents Reporting Nuclear Wastes..................6-5

6.2 Respondents Reporting Use of Sealed Sources Not Producing Nuclear Wastes....................6-7

6.3 Respondents Reporting No Waste......................6-9

6.4 Sealed Sources Produc1ng Sh1pped Nuclear Waste............6-11

6.5 Millicuries of Nuclear Waste Shlpped by Facility Type.......6-15

6.6 Cubic Meters of Solid Nuclear Waste Shipped..............6-19

6.7 Liters of Liquid Nuclear Waste Shipped by Facility Type.....6-23

6.8 Percent Responses to the Survey......................6-26

6.9 Nuclear Waste Shipped in Millicuries..................6-28

6.10 Nuclear Waste Shipped Classified by Hazard...............6-32

6.11 Nuclear Waste Shipped Classified by Container Type Form......6-34

6.12 Nuclear Waste Shipped Classified by Physical Form.........6-36

6.13 Nuclear Waste Shipped Classified by Reduction Process Used...6-38 
3.1 The State Economic Areas of South Carolina...............

3.2 Rates of Population Change Between 1970 and 1975 for the State Economic Areas of South Carolina.....................14

3.3 Population Density (Persons Per Square Mile) for the State Economic Areas of South Carolina.........................

4.1 The Congressional Districts of South Carolina.............4-2

4.2 Senatorial Districts of South Carolina..................4-12

4.3 House of Representatives Districts...................4-14 
This South Carolina State Briefing book for Low-Level Radioactive Waste Management has been prepared to assist in the orderly planning and implementation of safe, adequate low-level radioactive waste disposal facilities. The book is one of a series of briefing books being prepared that will provide background information on waste management practices in all states.

Of six commercial low-level radioactive waste disposal sites that have operated within the United States, only three are currently accepting additional wastes. Of these, two have been closed intermittently because or various irregulatities in disposal and shipping operations. In 1979, approximately 80 percent of the wastes were shipped to the South Carolina site.

Projections of total national low-level radioactive waste generation and capacity of existing commercial disposal facilities indicate that if no change in present practices or trends occurs, the current disposal sites could be filled by the mid-1990s. Recent proposed limitations of yearly burial quantities to be accepted by disposal sites in the states of South Carolina and Washington will reduce avallability of burial space. South Carolina's limit on waste recelpts will be reduced to 100,000 cubic feet per month by October 1981, and Washington will likely restrict use of the Richland site after 1982. It is possible that by the mid-1980s there could be more waste volume generated per year than could be buried.

Section 2 of this Briefing Book presents an overview of past and present low-level radioactive waste management practices within the state of South Carolina. Section 3 identifies those demographic and economic factors and trends that affect or can be related to the quantity and nature of low-level 
radioactive wastes within the state. Section 4 presents an overview of South Carolina's state government and identifles government institutions and agencies with statutory or other responsiblities affecting the generation, handing, and disposal of radioactive wastes within the state. The identities of state officials and other organizations concerned with on this issue are presented in the text. Section 5 presents the methodology employed for conducting a direct mail survey of radioactive material licensees within the state to obtain basic information on disposal practices. The results of this survey are presented in Section 6. 
There are approximately 365 radioactive material licensees in the state of South Carolina. These licensees generated approximately 4,940 cubic meters of low-level radioactive waste in 1978.1 South Carolina's commercial power reactors accounted for 62 percent of the total waste generated within the state. 2 Industrial wastes accounted for 30 percent, while institutional, government, and military wastes accounted for the remaining 8 percent. ${ }^{3}$

\section{Current Disposal Practices}

In 19798,089 cubic meters of low-level radioactive waste generated by South Carolina licensees was disposed of at commercial burial facilities. Over 99 percent of the waste was shipped intrastate to the Barnwell disposal site, the remainder to Richland, Washington. 4 Thirty percent of the waste disposed of at commercial burial facilities was generated by commercia $i$ power reactors. 5 The remaining 70 percent was generated by industrial. institutional, government, and military factlities. 6

\section{Regulatory Enforcement}

The U.S. Atomic Energy Commssion (AEC) was the tirst agency to develop regulations for the control of low-level radioactive wastes. The U.S. Energy Research and Development Agency, Department of Energy, Nuclear Regulatory Commission, Environmental Protection Agency, and Department of Transportation have all promulgated regulations affecting radioactive waste management. In 1969, South Carolina was designated as an "Agreement State:" with specific regulatory authority to control and regulate low-level radioactive material. 
South Carolina and the states of Nevada and Washington have regulations covering the packaging and shipping of low-level radioactive wastes. Shipments of level wastes that are improperly packaged or are in violation of NRC regulations may be rejected at the disposal site. 
Introduction

- This demographic study for South Carolina is designed to analyze various demographic factors, data, and trends that could be related to the quantity, nature, and potential management options of low-level radioactive wastes within the state and its political subunits.

\section{State Economic Areas:}

The study covers the State of South Carolina as a whole and its subunits, namely, its State Economic Areas (SEAs). State Economic Areas'are frequently used in demographic studies of states because states are generally heterogeneous in terms of urban-rural distributions, climate, industry, topography, population size and growth, and economic activity that it is infeasible to investigate these phenomena strictly at the state level. It is necessary to reduce the state's geography into smaller units, but not so small that their number becomes too cumbersome for analysis, as might be the situation if one were to break the state down into counties. The State Economic Area is an appropriate unit for the subject in this study, midway between the state and the county.

State Economic Areas are relatively homogeneous subdivisions of $a$ state, consisting of single counties or groups of counties that have similar economic and social characteristics. The boundaries of these areas have been drawn in such a way that each state is subdivided into relatively few parts, with each part having significant characteristics that distinguish it from adjoining areas. 
In the establishment of State Economic Areas, factors in addition to industrial and commercial activities were taken into account. Demographic, climatic, physiographic, and cultural factors, as well as factors pertaining more directly to the production and exchange of agricultural and non-agricultural goods, were examined.

State Economic Areas that contain the counties of the larger Standard Metropolitan Statistical Areas (SMSAs), metropolitan areas that in 1960 had central cities of 50,000 or more and total populations of 100,000 or more, are recognized as metropolitan SEAs and are designated by the name of the respective metropolitan areas. The bulk of the SEAs, however, are nonmetropolitan and have names that reflect either their locations in their states, their particular economic activities, or both. The nonmetropolitan SEAs are identified numerically, the metropolitan SEAs with letters.

. The State of South Carolina is divided into 12 State Economic Areas, eight of which are nonmetropolitan: SEA 1: South Carolina Blue Ridge - Piedmont Transition; SEA 2: Northwestern South Carolina

Piedmont; SEA 3: North Central South Carolina Piedmont; SEA 4: South Carolina Lower Piedmont; SEA 5: South Carolina Sand Hills; SEA 6: South Carolina Upper Coastal Plain; SEA 7: Pee Dee River; and SEA 8: South Carolina Coast. The remaining four SEAs are metropolitan: SEA A: Columbia SMSA; SEA B: Augusta SMSA (South Carolina part); SEA C: Charleston SMSA; and SEA D: Greenville SMSA. These SEAs are outlined and identified, along with major cities in the state, in Map 3.1. The counties in each SEA are listed in the appendices. 
Map 3.1 The State Economic Areas of South Carolina

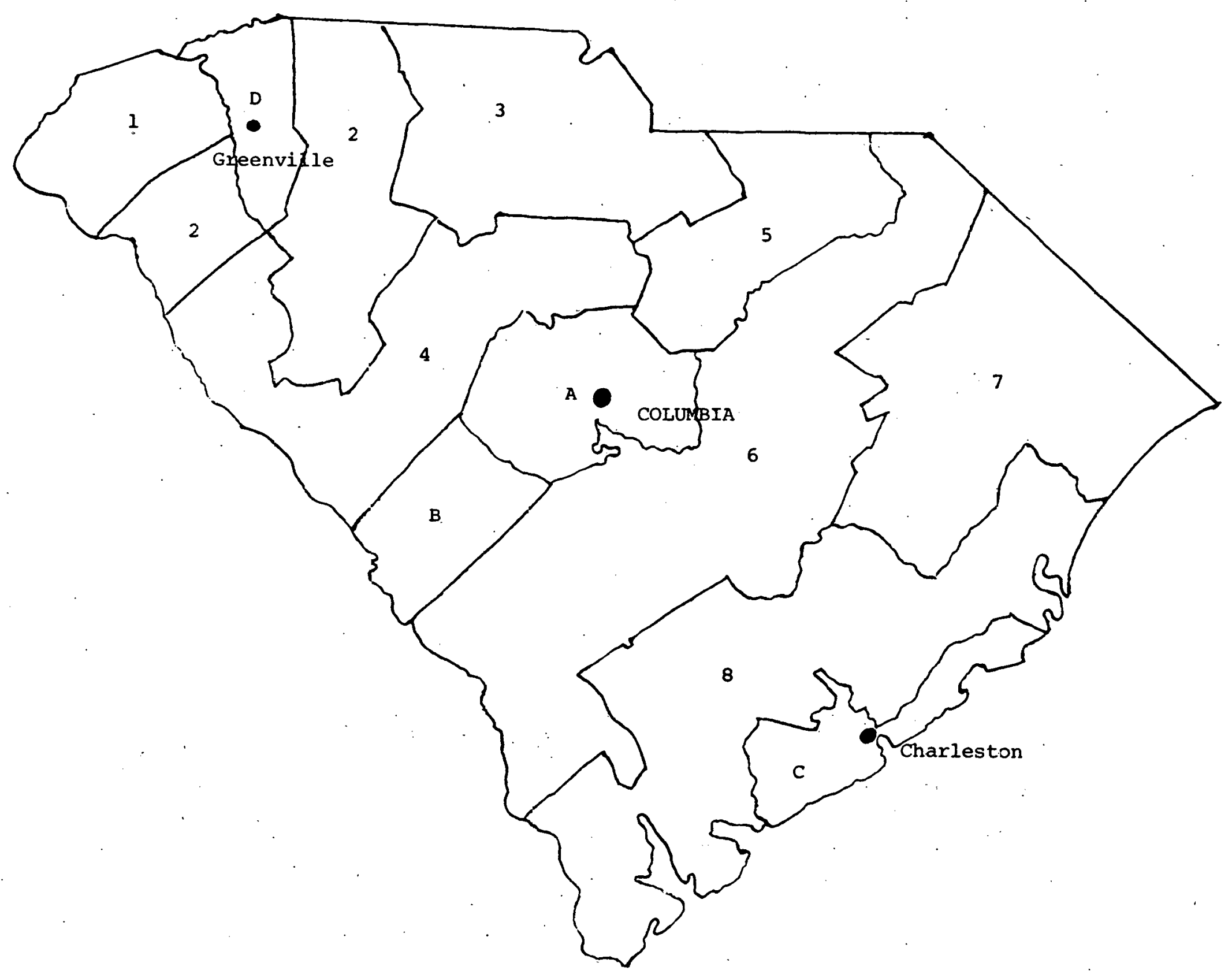




\subsection{Population and Location}

Population data is presented because the use of certain radioactive materials can be related to population and age structure. The population of South Carolina on April 1, 1980 was 3,119,208, according to a final count of the returns of the 1980 Census of Population. This figure is an increase of some 528,000 , or over 20 percent, from the $2,590,713$ inhabitants counted in the 1970 Census. In this section the population of the state and its SEAs is described in terms of their age composition in 1978, 1980, and 1990. The data for 1980 and 1990 are based on population projections and the data for 1978 on population estimates developed by the Bureau of the Census. At the time of this writing, age and sex data from the 1980 Census have not yet been released.

Population bar graphs have been developed for the state and each SEA that depict age compositions. Figures 3.1 .1 through $3.1 . \mathrm{V}$ are for the SEAs and Figure 3.1.13 for the state as a whole.

These graphs show that the metropolitan SEAs (Figures 3.1.A through $3.1 . D)$ are largely characterized by concentrations of young men and women in the late teens through the mid-to-late $20 \mathrm{~s}$, a distribution generally observed in most metropolitan areas. Compared to the nonmetropolitan SEAs (Figures 3.1.1 through 3.1.8), the metropolitan SEAs have slightly fewer persons in the younger ages proportionately.

Table 3.1 presents population projection data for the SEAs and the state for 1980 and 1990. Nineteen-eighty 1980 data are provided on the basis of projections based on assumptions generally governing demographic conditions of fertility, mortality, and migration as they existed in the 

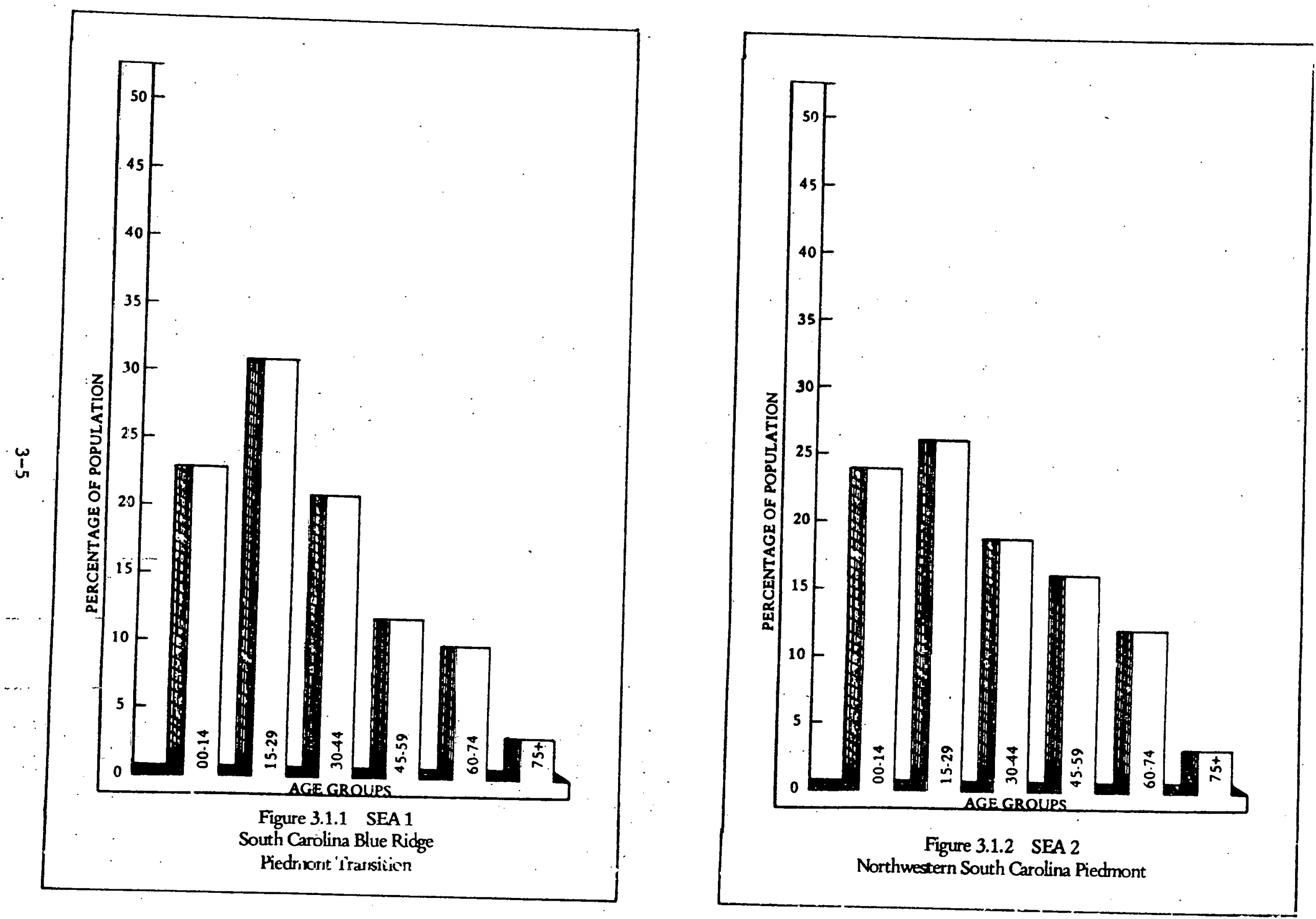

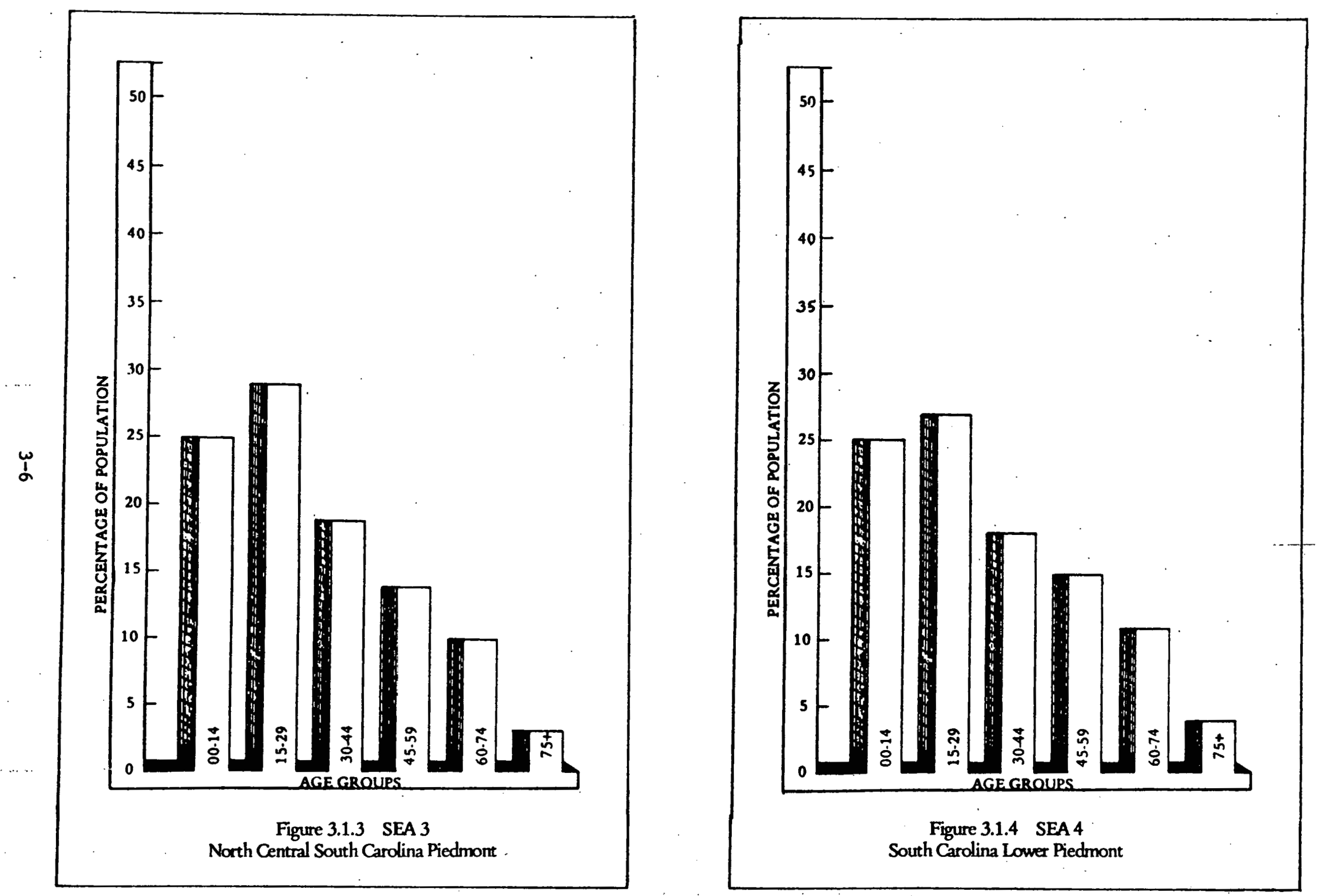

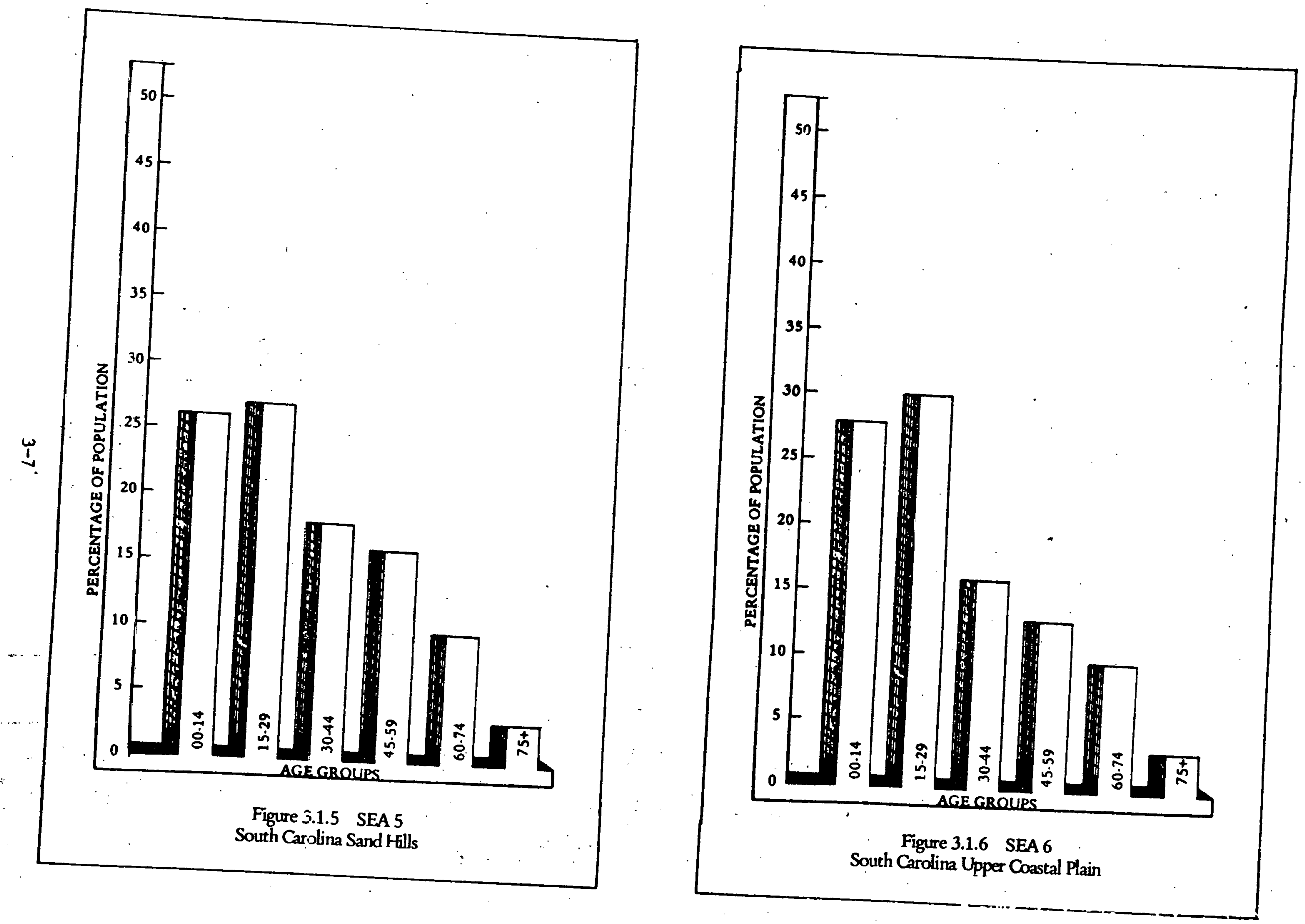

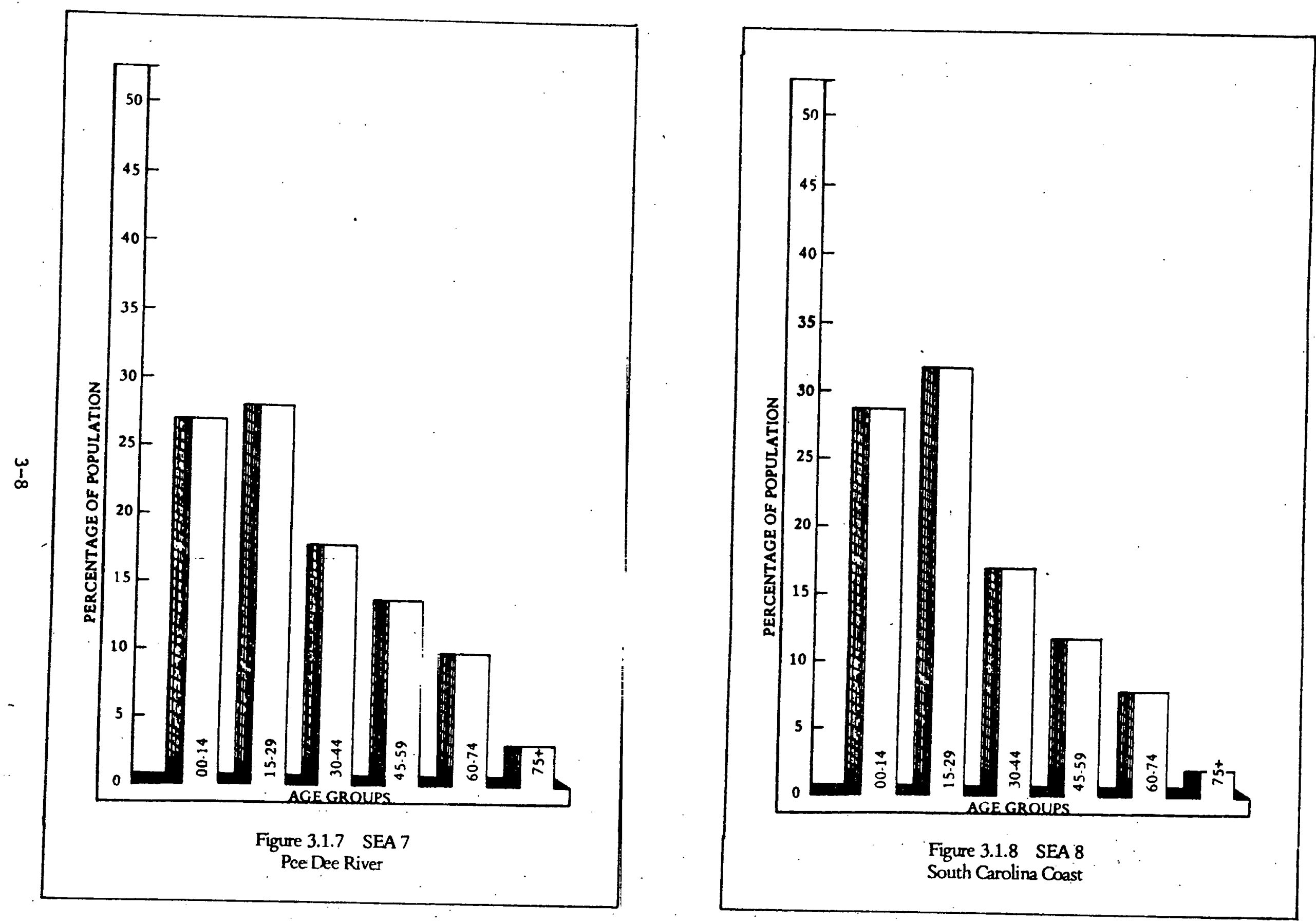

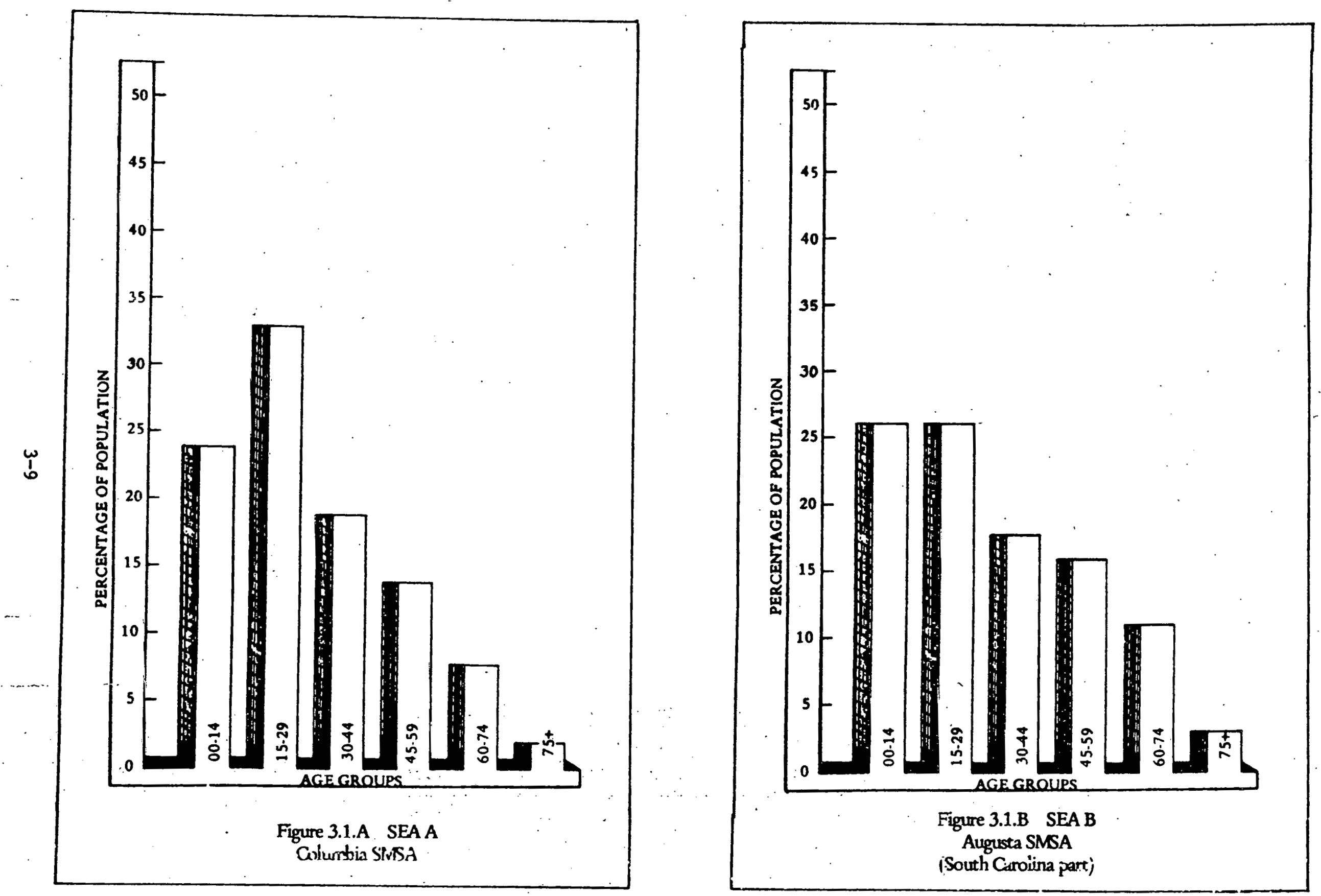

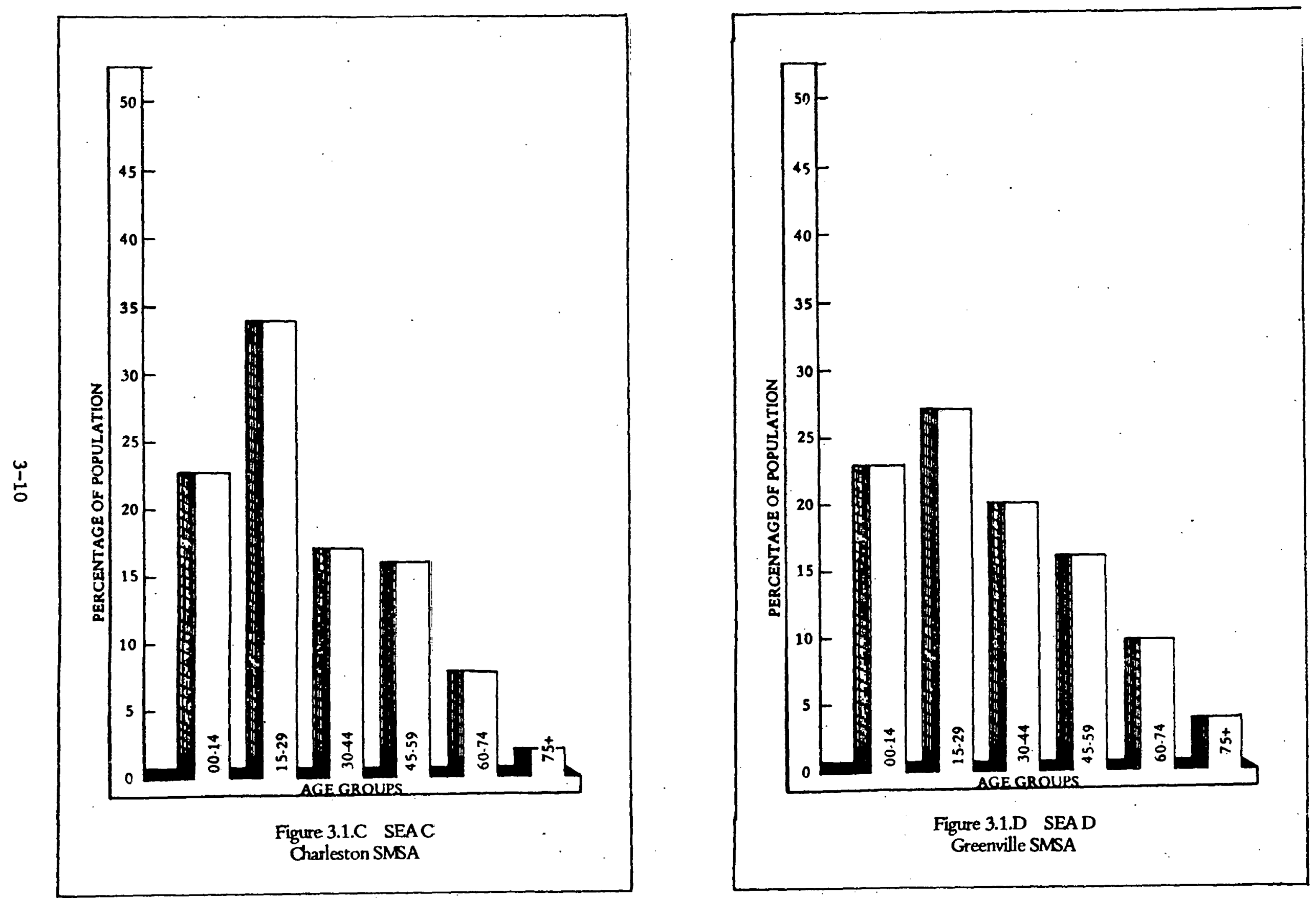


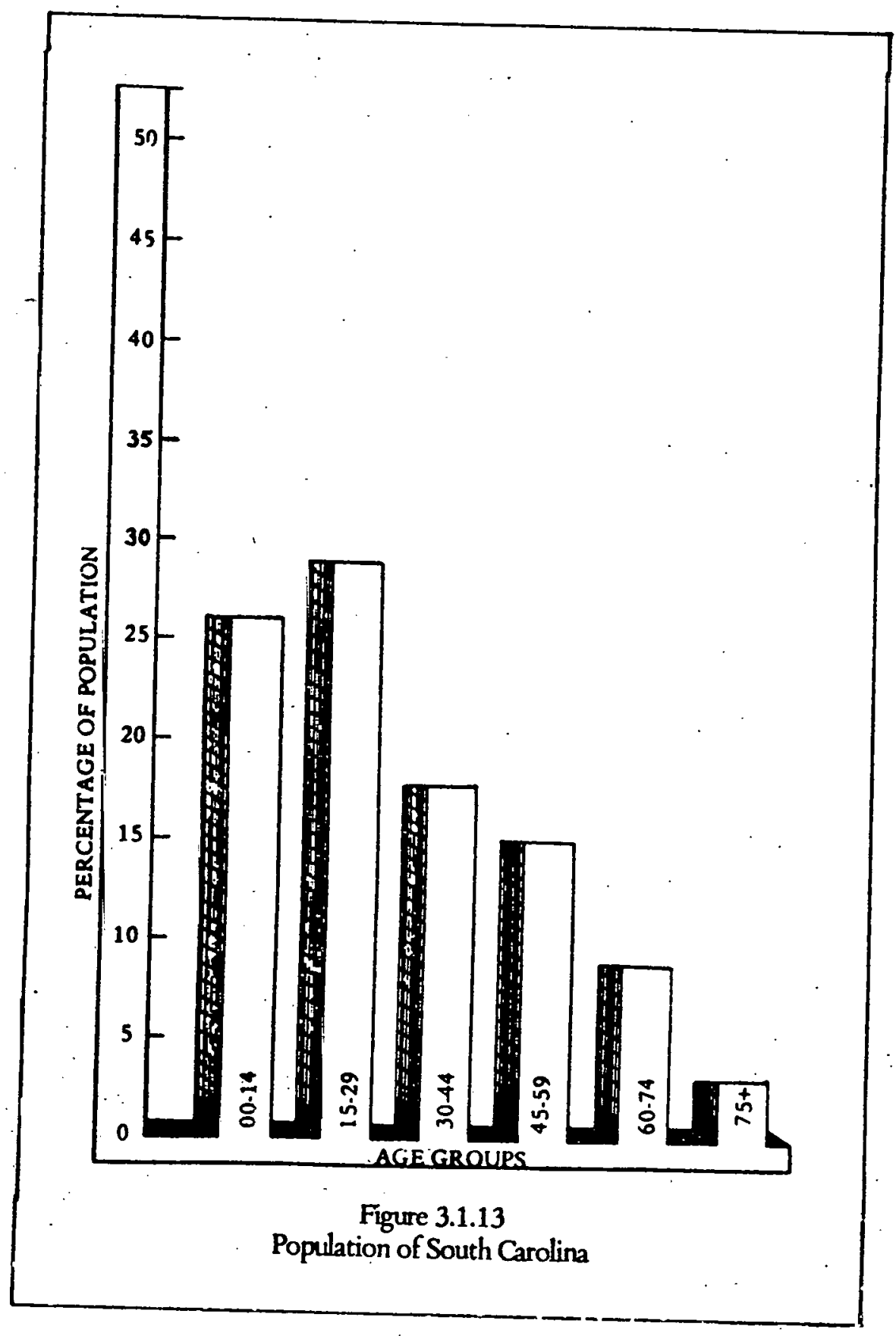


Table 3.1 Demographic Growth and Density Information for the State of South Carolina and its State Economic Areas

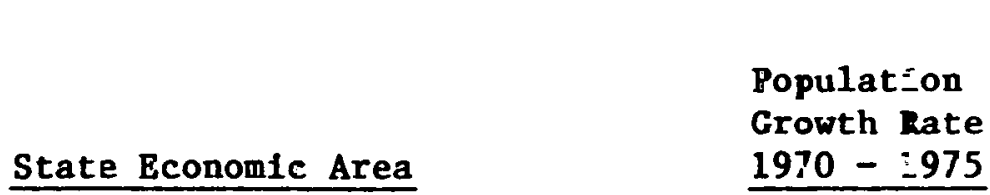

SEA 1 SC Blue Ridge-Pledmont Trans.

SEA 2 Northwestern SC. Pledmont

SEA 3 North Central SC Piedmont

SEA 4 SC Lower Pledmont

SEA 5 SC Sand Hills

SEA 6 SC Upper Coastal Plain

SEA 7 Pee Dee River

SEA 8 South Carolina Coast

SEA A Columbia SMSA

SEA B Augusta SMSA ( SC part)

SEA C Charleston SMSA

SEA D Greenvi11e SMSA

state of South Carolina
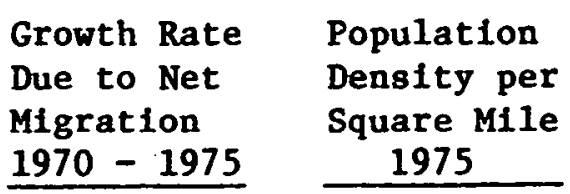
Population
Projection
1980

Population

Projection

1990

\begin{tabular}{rrrrr}
$12.0 \%$ & $7.7 \%$ & 97 & 130,332 & 157,762 \\
$8.1 \%$ & $4.3 \%$ & 149 & 447,702 & 522,642 \\
$6.4 \%$ & $1.5 \%$ & 89 & 259,787 & 289,793 \\
$2.3 \%$ & $-1.7 \%$ & 35 & 115,359 & 114,659 \\
\hline $4.0 \%$ & $-1.2 \%$ & 45 & 76,416 & 81,272 \\
\hline $5.4 \%$ & $-0.1 \%$ & 59 & 370,620 & 405,908 \\
$10.5 \%$ & $4.4 \%$ & 73 & 314,439 & 373,955 \\
$15.2 \%$ & $6.1 \%$ & 51 & 285,989 & 364,674 \\
$13.0 \%$ & $8.8 \%$ & 249 & 431,796 & 549,729 \\
$4.6 \%$ & $-0.7 \%$ & 87 & 103,251 & 112,563 \\
$5.1 \%$ & $-0.4 \%$ & 277 & 281,179 & 315,802 \\
$10.2 \%$ & $5.5 \%$ & 335 & 302,528 & 363,248 \\
$8.6 \%$ & $3.3 \%$ & 93 & $3,119,398$ & $3,652,225$
\end{tabular}


last half of the 1960s and the early 1970s. In the case of migration, trends in the state and its SEAs through 1978 were used to generate 1980 projections.

The 1980 data in Table 3.1 show the continued prominence of three SEAs in total population: SEA 2: Northwestern South Carolina Piedmont; SEA 6: South Carolina Upper Coastal Plain; and SEA A: Columbia SMSA. The data presented for 1990 in Table 3.1 suggest the continued predominance of these. SEAs as the major population focal points in the state.

Demographic growth and density information for South Carolina and its SEAs is also presented in Table 3.1. Rates of population growth between 1970-75 are included, along with growth rates due to net migration. Data on population density (number of persons per square mile) are also presented. These data are of interest because a population with a positive rate of growth over a five-year period, particularly one with a positive rate due to net migration, would imply increasing isotope use and waste generation. The Greenville, Charleston, and Columbia SEAs are the mosi densely populated, with 335, 277, and 249 persons per square mile.

Another way of viewing demographic patterns and changes in South Carolina and its SEAs is through maps. Maps reflecting rates of overall population growth for South Carolina SEAs (Map 3.2) and patterns of population density per square mile for the SEAs according to three categories of density (Map 3.3) are included. 


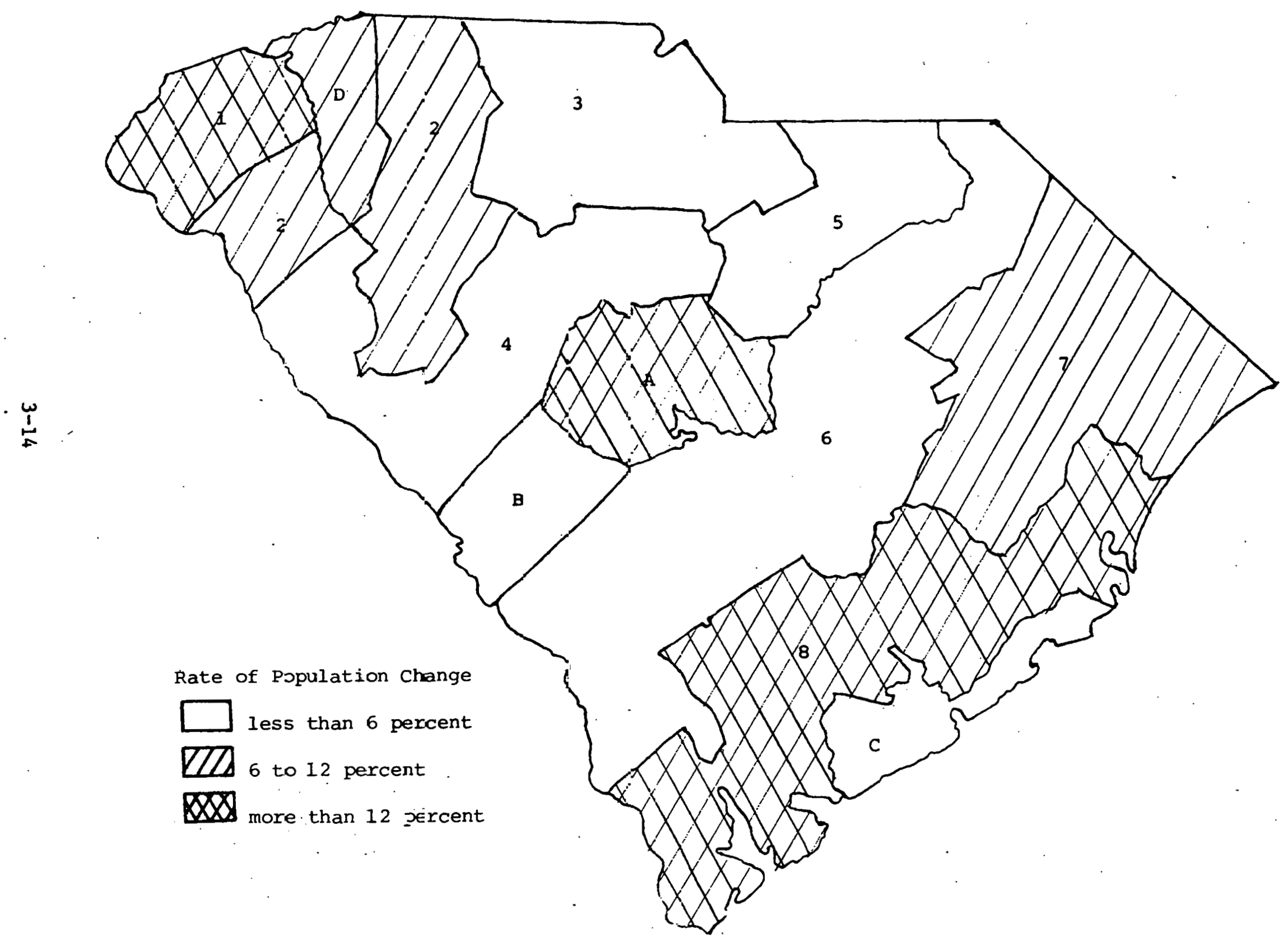


Map 3.3 Population Density (Persons per Square Mile) for the State Economic Areas of South Carolina

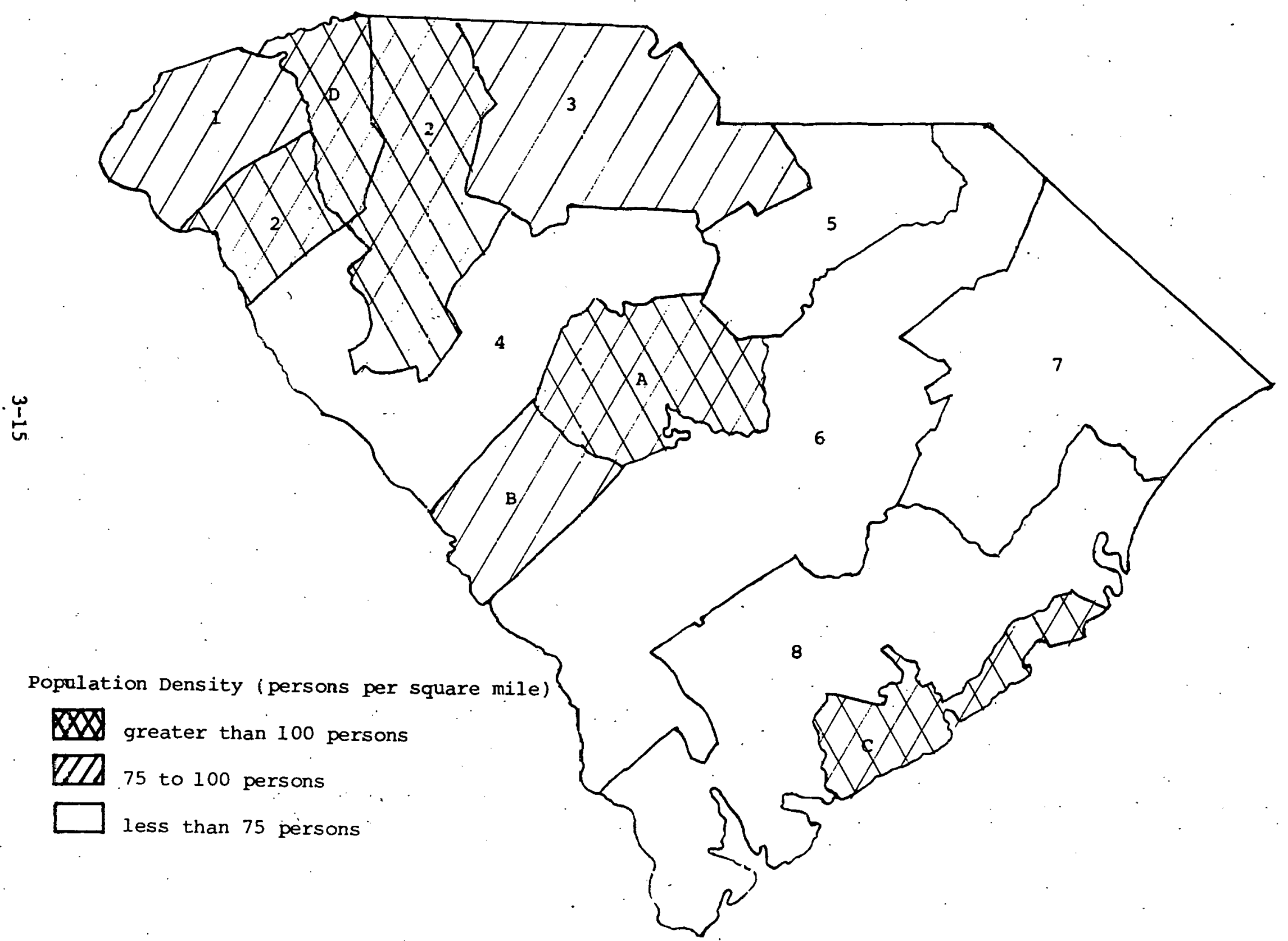




\subsection{Agriculture}

Demographic data on agriculture for South Carolina and its SEAs indicate those areas within the state heavily engaged in agricultural pursuits. Data of this type could be influential in determining which areas within the state could be candidates for facilities for low-level radioactive waste inanagement, and which areas should not be.

Table 3.2 presents information for the state and its SEAs on the total amount of land in farms (expressed in thousands of acres) in 1974 and 1978, the percent of al1 land devoted to farming in 1974 and 1978, and the average value of land and buildings per farm (in thousands of dollars) in 1974 and 1978.

Acreage designated as "land in farms" consists primarily of agricultural land used for crops, pasture, or grazing. It also includes woodland and wasteland not actually under cultivation or used for pasture or grazing, provided it was part of the farmer's total operation. Large acreages of woodland or wasteland held for nonagricultural purposes were deleted from individual reports during the census processing procedures. Except for open range and grazing land used under government permits, all grazing land was included as "land in farms," provided the place was part of a farn or ranch.

The State Economic Area in South Carolina with the greatest number of acres devoted to farming in 1978 was SEA 6: South Carolina Upper Coastal Plain, with over 1.9 million acres, a slight increase over the acreage devoted to farming in 1974. The Charleston SMSA (SEA C) had the fewest acres devoted to farming in 1978. In the total amount of land in the area 
Table 3.2 Agricultural Data for the State of South Carolina and 1ts State Economic Areas, 1974 and 1978

\section{State Economic Area}

SEA 1 SC Blue Ridge-Pledmont Transition

SEA 2 Northwestern SC Pledmont

SEA 3 North Central SC Pledmont

SEA 4 SC Lower Pledmont

SEA 5 SC Sand Hills.

SEA 6 SC Upper Coastal Plain

SEA 7 Pee Dee River

SEA 8 South Carolina Coast

SEA A Columbia SMSA

SEA B Augusta SMSA (SC part)

SEA C Charleston SMSA.

SEA D Greenville SMSA

State of South Carolina

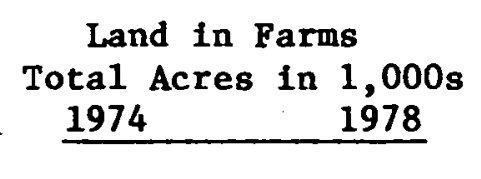

148

594

120

585

509

582

264

1849

999

669

231

173

75

87

6177

\begin{abstract}
Average Value of Land and Butldings per Farm in $\$ 1,000$ s 1974 1978
\end{abstract}

\begin{tabular}{|c|c|}
\hline 88 & 101 \\
\hline 87 & 140 \\
\hline 94 & 131 \\
\hline 97 & 147 \\
\hline 88 & 143 \\
\hline 117 & 225 \\
\hline 84 & 182 \\
\hline 99 & 174 \\
\hline 130 & 162 \\
\hline 91 & 146 \\
\hline 159 & 226 \\
\hline 92 & 130 \\
\hline 99 & 146 \\
\hline
\end{tabular}

Percent of Land Devoted to Farming 1974 1978

\begin{tabular}{ll}
20.1 & 16.3 \\
33.9 & 33.6 \\
29.6 & 27.8 \\
28.9 & 27.2 \\
26.2 & 24.9 \\
47.2 & 49.0 \\
41.2 & 41.0 \\
21.9 & 20.0 \\
24.6 & 22.1 \\
24.8 & 23.1 \\
12.4 & 10.6 \\
17.1 & 18.3 \\
31.9 & 32.6 \\
\hline
\end{tabular}


devoted to farming, the South Carolina Upper Coastal Plain (SEA 6) had the highest percentage in 1978, with about 49 percent of its land devoted to agriculture. As expected, the Charleston SMSA had the smallest portion of its land devoted to this purpose.

The Charleston SMSA had the highest average value of land and buildings per farm in 1978. After adjusting for inflation, this 1978 value represents an approximate 8 percent increase over the average value in 1974. The SEA with the largest acreage and the greatest proportion of land devoted to farming, the South Carolina Upper Coastal Plain, had the second highest average value of land and buildings per farm in 1978. This figure represents a 46 percent increase over its 1974 value, after adjusting for inflation. The average value of land and buildings per farm in South Carolina in 1978 was $\$ 146,000$, an adjusted increase of some 12 percent over its 1974 value.

\subsection{Health}

This section analyzes health data for the State of South Carolina and its State Economic Areas. This information is provided because of the importance of radioactlve materials at many health care facilities. Table 3.3 provides the following information for 1975: number of hospitals, number of hospital beds, hospital beds per 100,000 population, and physicians per 100,000 population. The data on hospitals and beds were collected by the American Hospital Association for all hospitals accepted for registration by the Association. The data on physicians were collected by the American Medical Association and refer to professionally active non-federal physicians.

In absolute numbers of hospitals and beds, Columbia (SEA A) and Charleston (SEA C) lead. The distribution of hospital beds and physicians 
Table 3.3 Health Information for the State of South Carolina and its State Economic Areas, 1975

\section{State Economic Area}

SEA 1 SC Blue RIdge-Piedmont Transition SEA 2 Northwestern SC Pledmont

SEA 3 North Central SC Pledmont

SEA 4 SC Lower Pledmont

SEA 5 SC Sand H111s

SEA 6 SC Upper Coastal Plain

SEA 7 Pee Dee RIver

SEA 8 South Carolina Coast

SEA A Columbia SMSA

SEA B Augusta SMSA (SC part)

SEA C Charleston SMSA

SEA D Greenville SMSA

State of South Carolina

\begin{tabular}{cc}
$\begin{array}{c}\text { Number of } \\
\text { Hospital } \\
\text { Beds }\end{array}$ & $\begin{array}{c}\text { Hospital Beds } \\
\text { per 100,000 } \\
\text { Population }\end{array}$ \\
\hline
\end{tabular}

Physictans

Number of Hospitals

Population

per 100,000

Population

363

325

60

8

1777

434

113

8

1104

462

56

6

243

219

49

2

278

391

61

13

1260

348

62

13

1323

473

83

6

569

232

57

11

7237

1982

154

1

138

145

70

8

2057

790

287

1349

507

143

88

17698

629 
calculated on a per population basis is more even than when calculated as absolute counts. It would appear that these urban SEAs are the major sites for radionuclide use in a hospital/ medical context in South Carolina.

\subsection{Higher Education}

Colleges and universities are major users of radionuclides. Table 3.4 provides information on higher education in South Carolina and its SEAs for the academic years 1974-75. and 1977-78. In the year ending In 1975, there were 53 colleges and universities in South Carolina with a student enrollment of over 100,000. Three years later the number of institutions had increased to 61 , and the student enrollment had increased to more than 130,000 .

The geographical distribution of institutions of higher education and student enrollments in South Carolina is uneven, with three SEAs containing over 59 percent of institutions and over 53 percent of student enrollments: Northwestern South Carolina Piedmont (SEA 2), Columbia (SEA $A)$, and Charleston (SEA C). The largest, university in the state, the University of South Carolina (Columbia) is located in SEA A. The second largest university, clemson, is located in SEA 1: South Carolina Blue Ridge - Piedmont Transition.

Consideration of isotope use and management should focus mainly on the Northwestern South Carolina Piedmont SEA, the Columbia and Charleston SEAs, and on SEA 1, South Carolina Blue Ridge - Piedmont Transition. These SEAs contain the bulk of student enrollments in the state. 
Table 3.4 Information on Institutions of Higher Education for the State of South Carolina and Its State Economic Areas: Academic Years 1974-75 and 1977-78

\section{State Economic Area}

SEA 1 SC Blue Ridge-Piedmort Transition

SEA 2 Northwestern SC Pledmont

SEA 3 North Central SC Pledmont

SEA 4 SC Lower Pledmont

$\stackrel{\omega}{N}$
Number of Post-Secondary Schools

\begin{tabular}{ll}
$1974-75 \quad 1977-78$ \\
\hline
\end{tabular}

$\begin{array}{rr}2 & 2 \\ 10 & 12 \\ 6 & 7 \\ 2 & 2 \\ 1 & 1 \\ 8 & 10 \\ 4 & 5 \\ 1 & 2 \\ 7 & 8 \\ 2 & 2 \\ 6 & 6 \\ 4 & 4 \\ 53 & 61\end{array}$

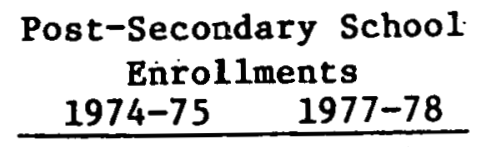

Enrollments

1974-75 1977-78

$\begin{array}{rr}9,777 & 11,878 \\ 11,630 & 16,445 \\ 6,734 & 8,497 \\ 1,554 & 1,539 \\ 372 & 579 \\ 8,230 & 11,338 \\ 7,017 & 8,462 \\ 320 & 1,377 \\ 29,157 & 34,750 \\ 1,238 & 2,642 \\ 13,559 & 18,412 \\ 10,846 & 14,449 \\ 100,434 & 130,368\end{array}$

SEA 6 SC Upper Coastal Plain

SEA 7 Pee Dee River

SEA 8 South Carolina Coast

SEA A Columbia SMSA

SEA B Augusta SMSA (SC part)

SEA C Charleston SMSA

SEA D Greenville SMSA

State of South Carolina 


\subsection{Government}

Demographic data on government employment and revenues in South Carolina and its SEAs provide information on the scope of local, state, and federal government activities and the extent to which they have changed in magnitude in recent years.

Data on government employment and payrolls are provided on Table 3.5 . The SEA with the greatest amount of government employees is the Columbia SMSA, with more than 13,000 ful1-time equivalent government employees in 1977. The Northwestern South Carolina Piedmont SEA and the South Carolina Upper Coastal Plain SEA run a close second and third, having almost 13,000 government employees in 1977. The State of South Carolina as a whole had the equivalent of more than 93,000 full-time government employees in the same year, an Increase of about 21 percent over 1972 levels.

As expected, the Columbia SMSA also has the most extensive local government payro11 in the state. In terms of 1972 dollars, the payroll in the Columbia SMSA increased by 47 percent between 1972 and 1977, for a total of over $\$ 10$ million. In the state as a whole, payrolls increased by about 27 percent in the same five year period.

Table 3.6 presents general revenue data, total intergovernmental revenue data, and the amount of intergovernmental revenue from the federal government for 1972 and 1977. The Northwestern South Carolina Piedmont SEA had the largest amount of general governmental revenue in 1977 in the state, more than $\$ 226$ million. This amount constitutes a gain between 1972 and 1977 of about 35 percent in terms of adjusted 1977 dollars. The Columbia SMSA had the largest rate of increase in revenue received from 
Table 3.5 Government Employment and Payroll Data for the

\section{State of South Carolina and its State Economic Areas}

\section{State Economic Area}

SEA 1 SC Blue Ridge-Piedmont Trans.

SEA 2 Northwestern SC Piedmont

SEA 3 North Central SC Piedmont

SEA 4 SC Lower Pledmont

SEA 5 SC Sand Hills

$\stackrel{\omega}{\omega}$

SEA 6 SC Upper Coastal Pla1n

SEA 7 Pee Dee River

SEA 8 South Carolina Coast

SEA A Columbia SMSA

SEA B Augusta SMSA (SC part)

SEA C Charleston SMSA

SEA D Greenville SMSA

State of South Carolina
Government Employment ${ }^{1}$

$\begin{array}{lll} & \text { ratio } \\ 1972 & 1977 & 1977 / 72\end{array}$

$2,462 \quad 3,003$

1.21

1.17

11,308

13,311

7,067

8,188

3,303

3,680

1.15

1.11

2,543

2,880

1.13

10,554

12,114

7,771

9,351

1.14

1.20

6,560

8,229

1.25

13,350

1.36

2,773

2,912

1.05

6,661

8,918

1.34

6,343

7,786

1.23

77,144

93,722

1.21
Local Government Payro11 2

Oct. oct. adj. ratio $^{3}$

$1972 \quad 1977 \quad 1977 / 72$

$\begin{array}{lrl}1.7 & 2.9 & 1.29 \\ 6.4 & 10.5 & 1.25 \\ 3.8 & 6.1 & 1.23 \\ 1.6 & 2.5 & 1.18 \\ 1.3 & 2.1 & 1.20 \\ 5.7 & 9.1 & 1.22 \\ 4.2 & 7.0 & 1.28 \\ 3.4 & 5.9 & 1.33 \\ 5.6 & 10.8 & 1.47 \\ 1.6 & 2.1 & 1.00 \\ 4.1 & 6.7 & 1.25 \\ 3.9 & 6.4 & 1.25 \\ 43.3 & 72.2 & 1.27\end{array}$

1 Government employment is expressed in terms of full-time equivalents.

2 Iocal government payrolls are expressed in millions of dollars.

3 As a control for inflation, the adjusted ratio of 1977 to 1972 payroll was cumritad after converting the 1.977 payroll dollars into their equivalent on the basis of 1972 do1lars. 
Table 3.6 Government Finance Data for the State of South Carolina and its State Economic Areas

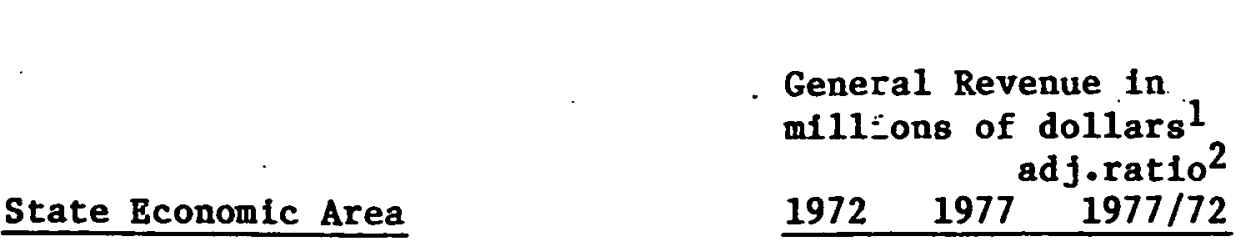

SEA 1 SC Blue Ridge-Pledmont Trans.

SEA 2 Northwestern SC Piedmont

SEA 3 North Cen \pm ral SC Piedmont

SEA 4 SC Lower Pledmont

SEA 5 SC Sand HAlls

SEA 6 SC Upper Coastal Pla1n

SEA 7 Pee Dee Ṙ̃er

SEA 8 South Carolina Coast

SEA A Columbia SMSA

SEA B Augusta SMSA (SC part)

SEA C Charleston SMSA

SEA D Greenville SMSA

State of South Carolina

$\begin{array}{rrrrrr}20.7 & 38.0 & 1.39 & 10.4 & 19.8 & 1.45 \\ 127.7 & 226.0 & 1.35 & 50.9 & 93.3 & 1.39 \\ 63.1 & 109.9 & 1.32 & 28.1 & 50.7 & 1.37 \\ 25.5 & 42.7 & 1.27 & 15.8 & 27.4 & 1.32 \\ 21.4 & 36.4 & 1.29 & 9.6 & 16.9 & 1.34 \\ 84.1 & 145.1 & 1.31 & 50.9 & 91.0 & 1.36 \\ 76.8 & 138.9 & 1.38 & 44.1 & 82.7 & 1.43 \\ 52.3 & 98.6 & 1.43 & 31.7 & 61.9 & 1.49 \\ 97.2 & 209.8 & 1.65 & 37.8 & 78.0 & 1.58 \\ 24.4 & 30.6 & .96 & 12.6 & 18.5 & 1.12 \\ 69.9 & 122.7 & 1.34 & 31.3 & 57.0 & 1.39 \\ 69.8 & 131.8 & 1.44 & 28.0 & 63.7 & 1.74 \\ 733.0 & 1330.7 & 1.39 & 351.2 & 661.3 & 1.44\end{array}$

Total Intergovernmental Revenue in millions of

\begin{tabular}{rr} 
millions of dollars & \\
adj.ratio & \\
$1972 \quad 1977 \quad 1977 / 72$ \\
\hline
\end{tabular}

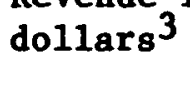

197

\section{adj. $\operatorname{ratio}{ }^{2}$} $1977 / 72$

$1972 \quad 1977-1977 / 72$

Intergovernment: Revenue from the Federal Govern (percentage)

1972

1977

2.5

3.9

13.0

20.4

10.1

15.9

17.1

26.9

5.8

9.1

5.8

9.1

9.3

30.3

17.2

27.0

11.3

23.8

10.0

12.4

16.5

24.9

7.1

28.6

$\begin{array}{lll}733.0 & 1330.7 & 1.39\end{array}$

1.44

12.1

21.3

1 General revence data are exclusive of interlocal revenue and are for the fiscal year which closed at various dates for each government during the 12 months ending June 30 of the particular year.

2 As a control for inflation, the adjusted ratio of 1977 to 1972 payroll was computed after converting the 1977 payroli dollars into their equivalent on the basis of 1972 dollars.

3 Intergovernmertal revenue data are exclusive of interlocal revenue. 
the federal government between 1972 and 1977, about 65 percent, and a general governmental revenue in 1977 nearly equal to that of the Northwestern South Carolina Piedmont, almost $\$ 210$ million. The State of South Carolina had total revenues in 1977 of over $\$ 1.3$ billion, an adjusted increase of about 39 percent over 1972 revenues.

In total intergovernmental revenue in 1977 , the Northwestern. South Carolina Piedmont SEA again was the most prominent State Economic Area in South Carolina, with over $\$ 93$ million. The state as a whole had over $\$ 661$ million in intergovernmental revenue in 1977. The Northwestern South Carolina Piedmont SEA received over 20 percent of its intergovernmental revenue from the federal government and the State of South Carolina more than 21 percent. 


\subsection{Economy}

This section describes the economy and distribution of economic activities in South Carolina in 1974 and 1978. Table 3.7 presents nine industrial categories and indicates the number of employees, annual payroll, and growth of payrolls between 1974 and 1978 for each category. The data reported pertain mainly to employment covered by the Federal Insurance Contributions Act (FICA). The data thus cover all workers except government and railroad employees, self-employed persons, and a small number of others.

The information describing industrial activities for South Carolina was taken from statistics provided in County Business Patterns, a source developed and published through the U.S. Bureau of the Census. County Business Patterns provides an annual report on the economic activities of a.l1 counties in the United States. In the following analysis, county data were aggregated into state data.

The manufacturing industry provided the major economic base for the state. In 1974 there were 380,584 manufacturing employees with an annual payroll of almost $\$ 3$ billion. In 1978 the state continued to exhibit the same general type of industrial concentration and distribution. The manufacturing industry group payrolls experienced an increase of 9 percent between 1974 and 1978, after adjusting for inflation, to an annual payroll total of over $\$ 4.2$ billion. Increases also occurred in most of the other industrial activities. For example, 1978 payrolls in the contract construction, retail trade, and services industry groups were all over $\$ 1$ million annually. The contract construction industry group experienced the greatest growth between 1974 and 1978 with a 52 percent increase in annual payroll over the period. 
Table 3.7 Economic Data ${ }^{1}$ for the State of South Carolina

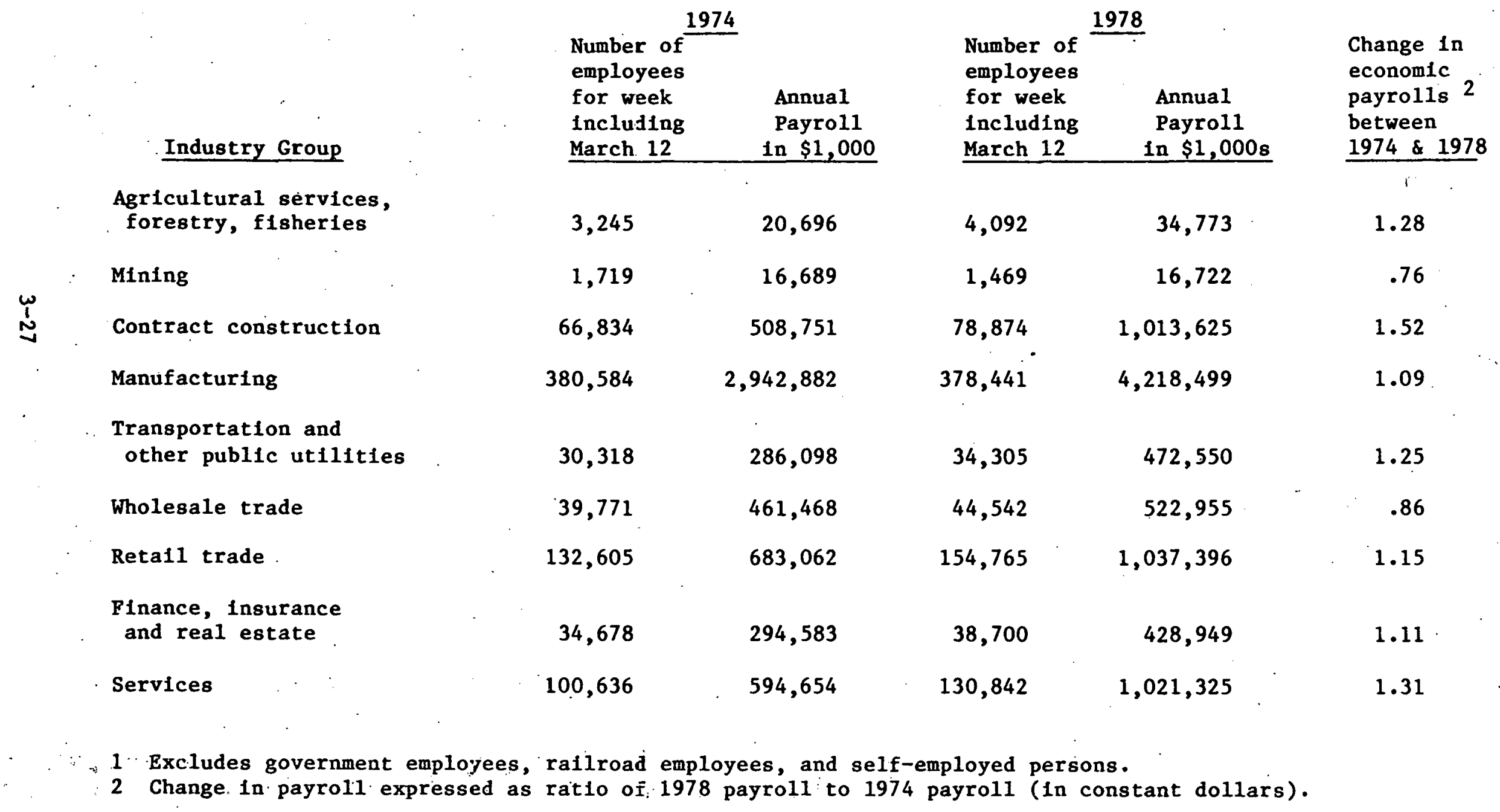




\section{References}

Poston, Dudley L., Jr. and Ervin, Delbert, A Technique for Estimating AgeSpecific Net Migration for Short Term Projections of County Populations; paper read at the annual meetings of the Population Association of America, Washington, D.C., March 1981.

Shryock, Henry S. and Siegel, Jacob S., The Methods and Materials of Demography; Volume 2, Chapter 24, U.S. Government Printing office, Washington, D.C.: April 1981.

U.S. Bureau of the Census, 1980 Census of Population and Housing, Final Population and Housing Unit Counts, PHC80-V-1; U.S. Government Printing Office, Washington, D.C.: April 1981.

U.S. Bureau of the Census, County Business Patterns, 19/4, and Lounty Business Patterns, 1978 ; Washington, D.C.; machine readable data files.

U.S. Bureau of the Census, County and C1ty Data Book, 1972; Washington, D.C.; magnetic tape version.

U.S. Bureau of the Census, Census of Governments, 1977; Washington, D.C.; machine readable data files. 
This section describes the structure and jurisdiction of South Carolina's executive, legislative, and judicial branches. A summary of state statutes and regulations relevant to low-level radioactive waste management and $a$ discussion of public interest groups that either have expressed or may have an interest in radioactive waste management is also included:.

\subsection{Major Political Parties}

The Democratic party has been the majority party in South Carolina since the Reconstruction Period. Democrats control 41 of the 46 seats in the South Carolina Senate and 107 of the 124 seats in the South Carolina House of Representatives. Governor Riley is also a Democrat.

\subsection{South Carolina Delegation}

South Carolina's United States Senators and Congressmen are:

\section{Senators}

Strom Thurmond (R)

209 Russell Senate Office Bullding Washington, D.C. 20510

(202) 224-5972

Ernest F. Hollings (D)

115 Russell Senate office Building Washington, D.C. 20510

(202) 224-6121
Senator Thurmond began service in the U.S. Senate in 1956. He is Chairman of the Judiciary Committee and a member of the Armed Services and Veteran's Affairs Committees.

Senator Hollings began service in the U.S. Senate in 1966. He is the ranking minority member of the Budget Committee and a member of the Appropriations and Commerce, Science, and Transportation Committees.

Congressman Harnett was first elected to the U.S. House of Representatives in 1980. He is a member of the Armed Services Committee. 


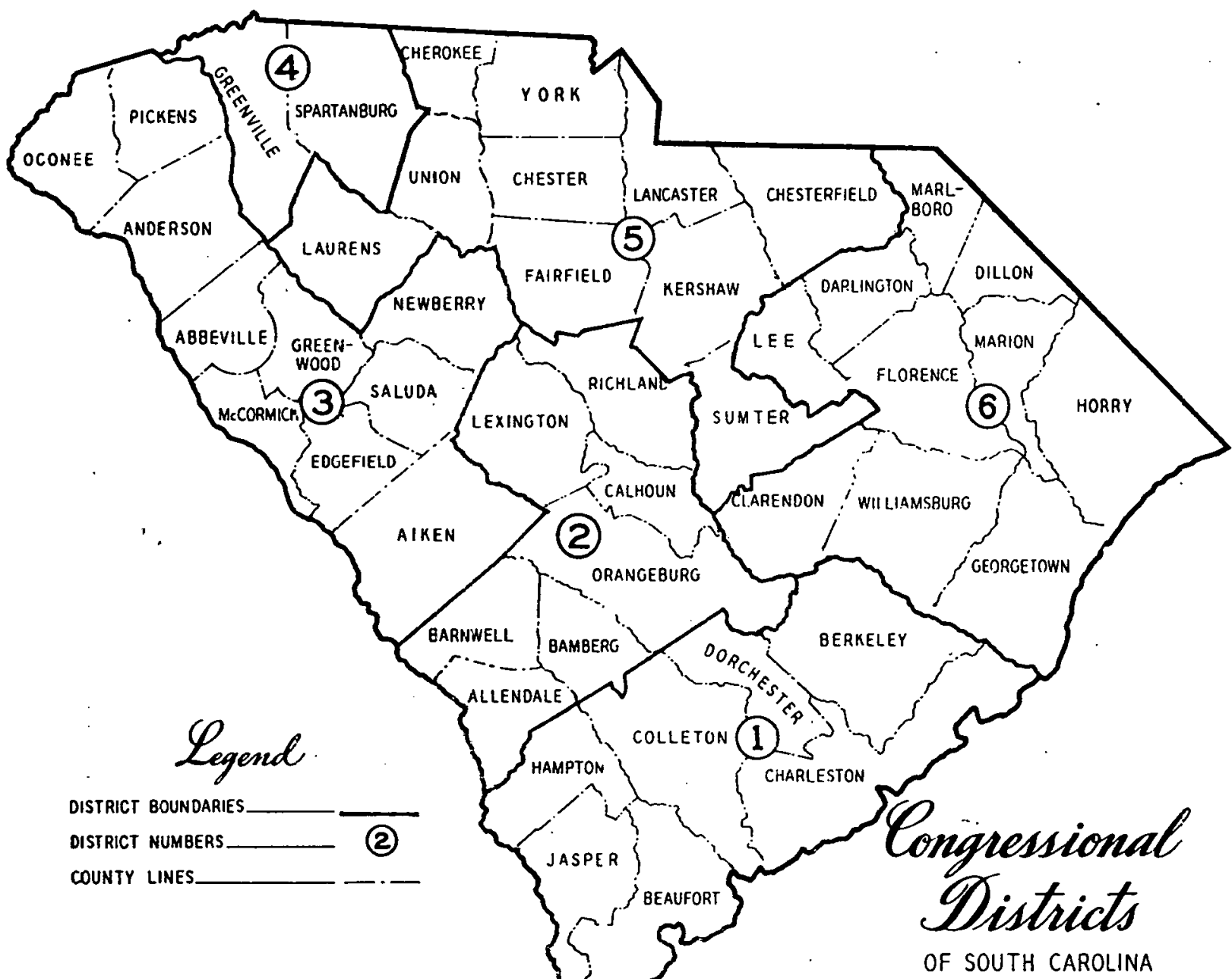


Representatives (cont.)

Floyd Spence (R)

2427 Rayburn House office Bullding Washington, D.C. 20515

(202) 225-2452

(2nd. District)

Butler Derrick (D)

133 Cannon House Office Building

Washington, D.C. 20515

(202) 225-5301

(3rd District)

Carrol1 A. Campbe11, Jr. (R)

408 Cannon House Office Bullding

Washington, D.C. 20515

(202) 225-6030

(4th District)

Ken Holland (D)

2431 Rayburn House Office Building Washington, D.C. 20515

(202) 225-5501

(5th District)

John L1ght Napier ( $R$ )

1631 Longworth House Office Bullding Washington, D.C. 20515

(202) 225-3315

(6th District)
Congressman Spence was first elected to the U.S. House of Representatives in 1970. He is the ranking minority member of the Standards of official Conduct Committee and a nember of the Armed Services Committee.

Congressman Derrick began service in the U.S. House of Representatives in 1974 . He is a member of the Rules and Aging Committees.

Congressman Campbell was first elected to the U.S. House of Representatives in 1978. He is a member of the Appropriations Committee.

Congressman Holland was first elected to the U.S. House of Representatives in 1974 . He is a member of the Ways and Means and Standards of official Conduct Committees.

Congressman Napier was first elected to the U.S. House of Representatives in 1980; . He is the Assistant Republican Whip and a member of the Agriculture Committee:

\subsection{State Government}

The Constitution of South Carolina establishes three branches within the state government: executive, leglslative, and judicial, which "shall be forever separate and distinct from each other" (Article I; Section 8). The following text describes the structure and jurisdiction of South Carolina's government. 


\subsubsection{Executive Branch}

South Carolina's executive branch comprises 23 departments and elected officers: Governor, Lieutenant Governor, Secretary of State, Adjutant General, Comptroller General, Department of Agriculture, Department of Archives and History, Department of Consumer Affairs, Department of Corrections, Department of Education, Department of Health and Environmental Control, Department of Highways and Public Transportation, Department of Insurance, Department of Juvenile Placement and Aftercare, Labor Department, Department of Mental Health, Department of Mental Retardation, Department of Parks, Recreation and Tourism, Department of Social Services, Department of Veteran's Affárs, Vucaliunal Rehabilitation Department, and Wildlife and Marine Resources Department.

\section{Office of the Governor}

The Governor of South Carolina is Richard Wilson Riley, a Democrat from Greenville. South Carolina's Governor is elected to a four-year term and may serve no more than two consecutive terms in office. The supreme executive authority of the state is vested in the Governor. He is empowered to recommend legislation to the General Assembly, convene the General Assembly, issue reports to the General Assembly, grant reprieves and commutations, appoint the members of boards and commissions, and exercise both the full and item veto. He may also require information in writing from the head of any agency or department pertaining to the duties of his/her office. The Governor serves as Chairman of the Budget and Control Board. Governor kiley also serves as Chairman of the State Planning Councll on Radioactive Waste Management. The Governor's address, his principal staff members, and his Washington office address follow. Governor Richard Riley

State House P.0. Box 11450 Columbia, South Carolina 29211 (803) $758-3208$ 
Governor's principal staff members:

Executive Assistant: Donald R. Hinson (758-3208)

Executive Assistant, Legislative Affairs: Dwight Drake (758-7115)

Deputy Assistant, Legislative Affairs: Willie E. DeLoach (758-711.5)

Executive Assistant, Legal Affairs: Dorothy A. Manigault (758-7115)

Executive Assistant, Education, Health and Human Services:

Milton Kimpson (758-7115)

Executive Assistant, Management and Finance: Katherine M. Clarke

Executive Assistant, Energy, Natural Resources and Economic

$(758-3208)$

Development: David Reed (758-7115)

Press Secretary: William Russell McKinney (758-7911)

Appointments Secretary: Gail Silver (758-3208)

Washington office:

South Carolina State. Office

444 N. Capital Street

Washington, D.C.

(202) 624-5300

Director - Steve B. Farber

Department of Health and Environmental Control

The Department of Health and Environmental Control comprises five offices: The Office of Environmental Quality administers programs pertalning to wastewater and stream quality control, solid waste management, air quality control, facilities evaluation, and environmental monitoring. The office of Health Protection contains the Bureau of Radiological Health. The Commissioner of the Department is:

Robert S. Jackson, M.D.

2600 Bull Street

Columbia, South Carolina 29201

(803) 758-5443

Bureau of Radiological Health. Contained within the Department of Health and Environmental Quality's Office of Health Protection is the Bureau of Radiolougical Health. Most state authority governing the installation, use, handling, transportation, and storage of radioactive materials has been concentrated within the Bureau. 
The Bureau is empowered to:

o Develop and conduct programs for the evaluation of radiation sources;

- Develop programs for the control, regulation, and surveillance of radiation sources;

- Adopt, promulgate, repeal, and amend regulations pertaining to the control of sources of radiation;

- Advise and consult with the Governor, General Assembly, and federal, state and interstate agencies regarding radiation control;

- Encourage, participate in, and conduct studies, research, and investigations pertaining to radiation control;

- Collect and disseminate information pertaining to radiation control; and

o Adopt and promulgate rules and regulations governing the transportation of radioactive materials within South Carolina.

The Chief of the Bureau of Radiological Health is:

Heyward G. Shealy

2600 Bull Street

Columbia, South Carolina 29201

(803) 758-5548

Technical Advisory Radiation Control Council

The Technical Advisory Kadiation Conliol Council comprises six members appointed by the Governor for terms of three years. The Councll advises the Department of Health and Environmental Control on matters pertaining to ionizing radiation. No standards, rules, or regulations may be promulgated, adopted, modified, or repealed by the Department unless they have been approved by the Counc11. The Chairman is:

U. Hoyt Bodle, M.D. 2600 Bull Street Columbia, South Carolina 29201 (803) $758-5.548$ 
Board of Health and Environmental Control

The Board of Health and Environmental Control comprises seven members appointed by the Governor, with the advice and consent of the Senate, to four-ytar terms. The Board supervises the administration of the Department of Health and Environmental Control. It also serves in an advisory capacity to municipal and county health authorities. The Chairman is:

William M. Wilson

2600 Bul1 Street

Columbia, South Carolina 29201

(803) $758-5443$

Governor's Nuclear Advisory Council

The Governor's Nuclear Advisory Council was created in 19.80. It provides advise to the Governor on issues involving the use, handling, management, transportation, storage, or disposal of nuclear materials within South Carolina. It also advises the Governor on federal programs relating to the establishment of a National Radioactive Waste Management Plan and the applicability of South Caroilna statutes and regulations to such planning. The Counc1l comprises five members appointed by the Governor. The Chairman is:

Brown Johnson

P.0. Box 1865

Florence, South Carolina 29503

\section{State Development Board}

The State Development Board comprises 19 members appointed by the Governor, with the advise and consent of the Senate, to five-year termis. The Board is responsible for promoting and developing atomic energy resources in South Caro11na. It is empowered to:

- Promote the establishment of private atomic energy facilities such as reprocessing plants, disposal sites, and transportation facilities;

- Advise the Governor and General Assembly on the development and promotion of atomic energy resources; 
o Coordinate atomic energy development within the state;

- Serve as a liaison between South Carolina and industry, the federal government, and other states;

- Consult and cooperate with South Carolina's university system for the promotion of atomic energy development.

The Chairman is:

Max Heller

1301 Gervais Street

Box 927

Columbia, South Carolina 29202

(80.3) 758-3145

\section{State Budget and Control Board}

The State Budget and Control Board comprises five ex officto members: the Governor, who serves as Chairman, State Treasurer, Comptroller General, Chairman of the Senate Finance Committee, and Chairman of the House Ways and Means Committee. The Board has custody over all state property and is empowered to:

- Expend state funds to acquire and develop land and facilities the Board believes will foster the development of the state's economic potential in the energy field;

- Lease, sublease, or sell real or personal property to publle ur pílvate interests; and

- Enter into agreements with the federal government to assume perpetual maintenance of lands donated, leased, or purchased from the federal government and used for the development of atomic energy resources or as a custodial site for radioactive materials.

The Boạd may be contacted at:

Office of the Governor

State House

P.O. Box 11450

Columbia, South Carolina 29211

(803) 758-3208 
Office of Energy Resources

The Office of Energy Resources implements and administers state and federal conservation programs, acts as a state clearinghouse for energy programs and actions affecting energy sources, implements educational programs on energy use, and encourages energy research. The Director is:

B. Kelly Smith

1122 Lady Street

Suite 1130

Columbia,. South Carolina 29201

(803) 758-7502

\section{South Carolina Water Resources Commission}

The South Carolina Water Resources Commission comprises 18 members. The Commission is empowered to:

- Advise and assist the Governor and the General Assembly on the formulation of a comprehensive water resources policy for the state;

o Develop and establish policies for water resource use and contrcl;

- Review the actions and policies of state agencies with water resourse responsibility; and

n Review fedcral prograws affecting the use or control of South Carolina's waters.

The Executive Director is:

Clair B. Guess, Jr.

Box 4515

3830 Forest Drive

Columbia, South Carolina 29240

(803) $758-2514$

\section{South Carolina Coastal Council}

The South Carolina Coastal Council was established to develop and implement a comprehensive coastal zone management program. It comprises 18 membe:s. The Chairman is:

Sen. James M. Waddell, Jr. 1116 Bankers Trust Tower Culumb1a, South Carolina 29201 (803) 758-8442 
State Land Resources Conservation Commission

The State Land Resources Conservation Commission comprises five members appointed by the Governor to terms of four years. It provides technical assistance to South Carolina's 46 conservation districts. The Executive Director is :

John W. Parris 2221 Devine Street Suite 222

Columbia, South Carolina 29205

(803) $758-2823$

\section{Southern States Energy Board}

The Southern States Energy Board was founded in 1961 as the Southern Interstate Nuclear Board. It serves the states of Texas, Georgia, South Carolina, Louisiana, Tennessee, North Carolina, Oklahoma, Alabama, Arkansas, Kentucky, Florida, Mississippi, West Virginia, Virginia, Maryland, Missouri, and the Commonwealth of Puerto Rice with technical assistance, program development, policy analysis, and research support. The activities of the Board staff are supervised by a Board of Directors composed of one member per state appointed by the Governor. In addition, the Suullitin 3tatca Encrgy Board has a Tiegislative Policy Advisory Council which consists of those state legislators serving on the Southern Legislative Conference Energy Committee. South Carolina's seat on the Board of Directors is held by:

B. Kelly Smith

Office of Energy Resources

1 L22 Lädy Streel

Suite 1130

Columbia, South Carolina 29201

(803) 758-7502 


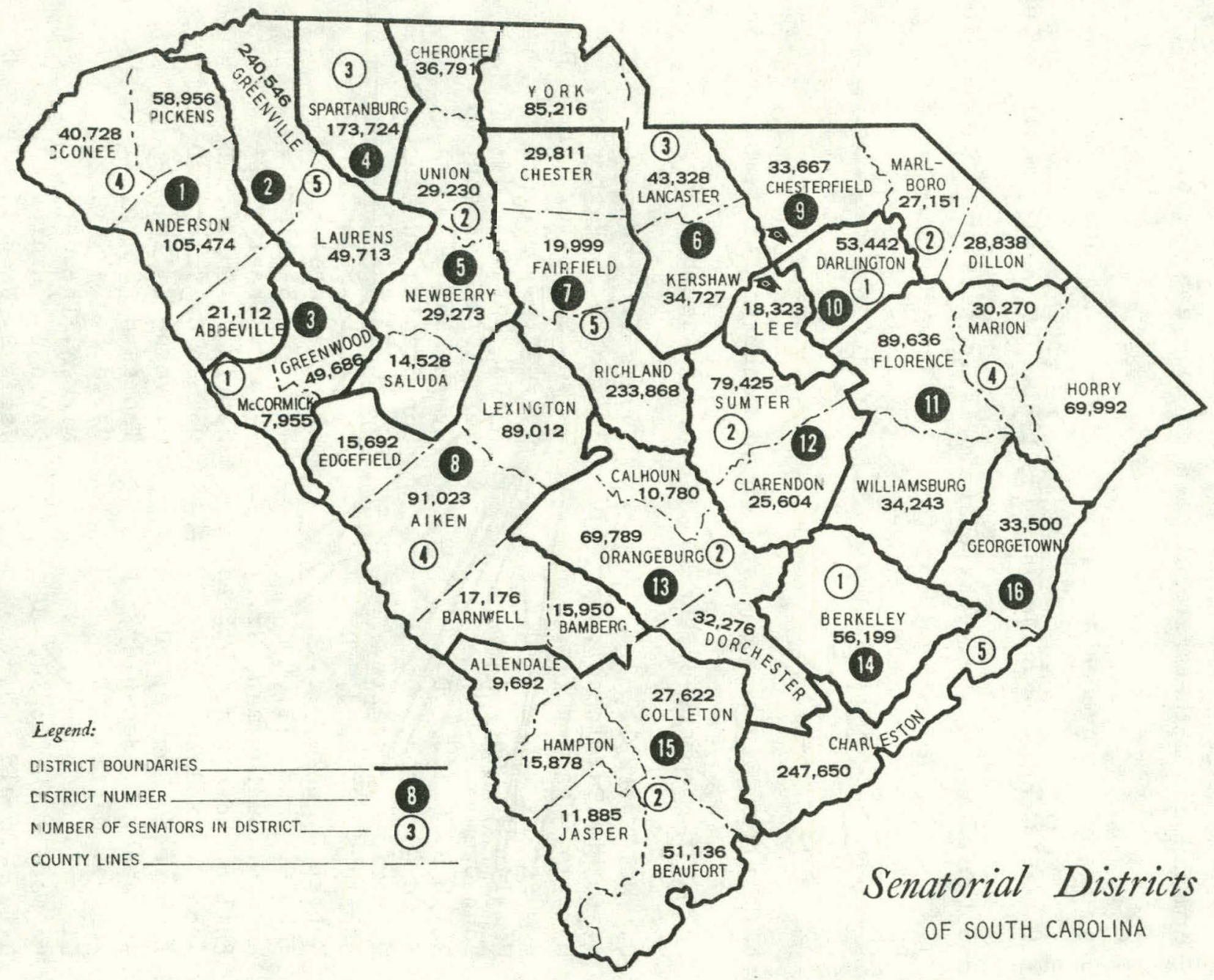


cast no vote except upon equal division of the House. In the absence of the President, the President pro Tempore presides over the Senate. He is elected by the members of the Senate. The officers of the Senate are:

President: Nancy Stevenson (Lieutenant Governor)

President pro Tempore: L. Marion Gressette (D, St. Matthews)

Majority Leader: L. Marion Gressette (D, St. Matthews)

Minority Leader: Jeff Richardson, Jr. (R, Greenville)

Committee Structure. There are 15 Senate Standing Committees in the 104th General Assembly of South Carolina. Committee Chairmen and members are elected by the Senate. Relevant Standing Committees are:

Agriculture and Natural Resources

Chairman: T. Ed Garrison (D, Anderson)

Finance

Chairman: Rembert C. Dennis (D, Moncks Corner)

$\underline{\text { Interstate Cooperation }}$

Chairman: L. Marion Gressette (D, St. Matthews)

Transportation

Chairman: John C. Lindsay (D, Bennettsville)

House of Representatives

The South Carolina House of Representatives consists of 124 members, 107 Democrats and 17 Republicans. The House members of the 104 th General Assenbly of South Carolina are:

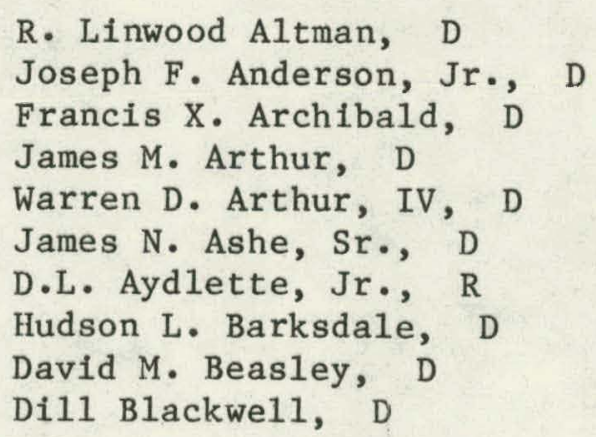

W. Sterling Anderson, D William E. Applegate, D Robert L. Helmly, D B.L. Hendricks, Jr., D Lloyd I. Hendricks, D Caldwe11 T. Hinson, D Charles E. Hodges, D D.N. Holt, Jr., D Ben F. Hornsby, D S. Hunter Howard, Jr., D 
$\frac{3}{1}$
$\stackrel{0}{0}$
$\stackrel{0}{\omega}$

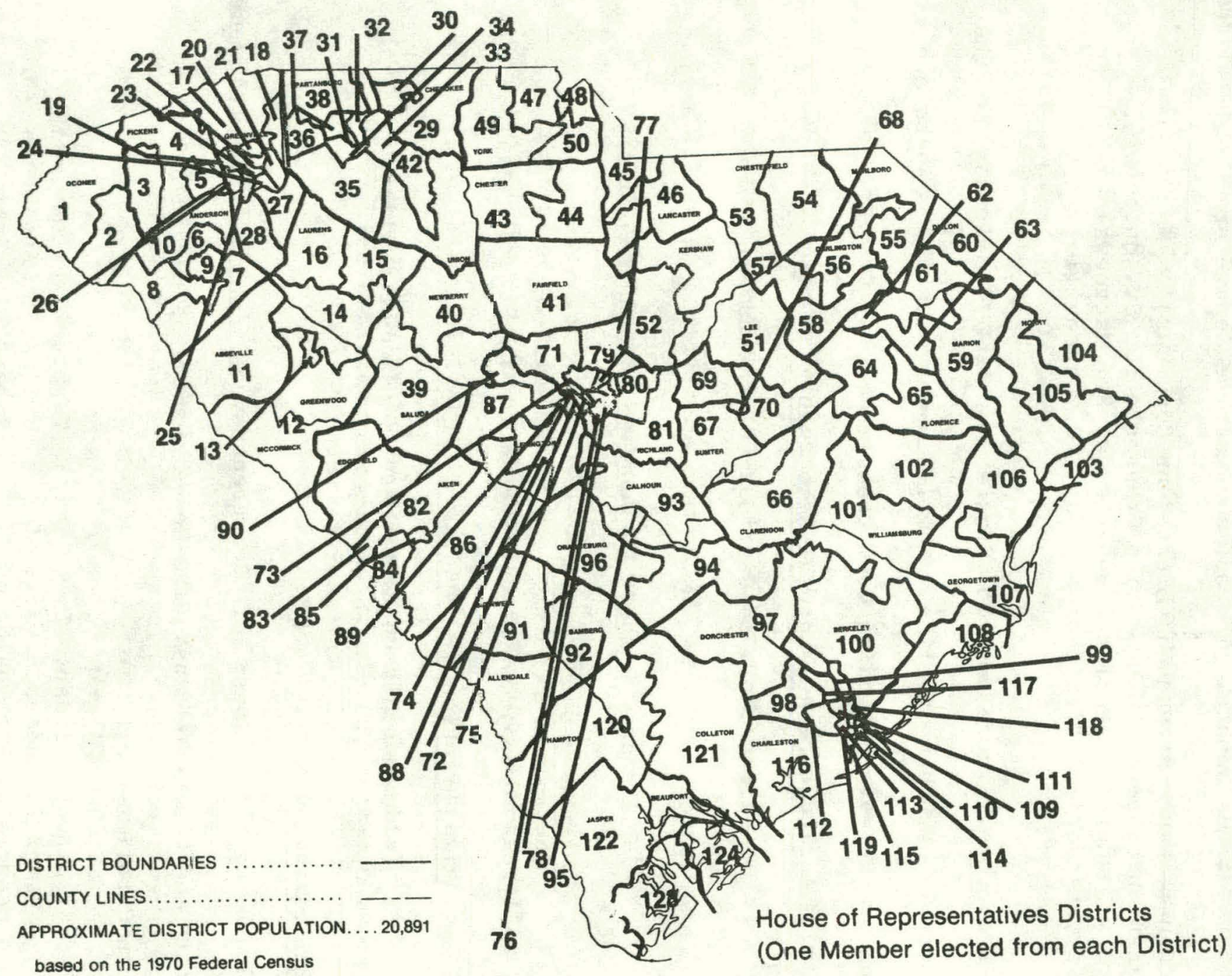




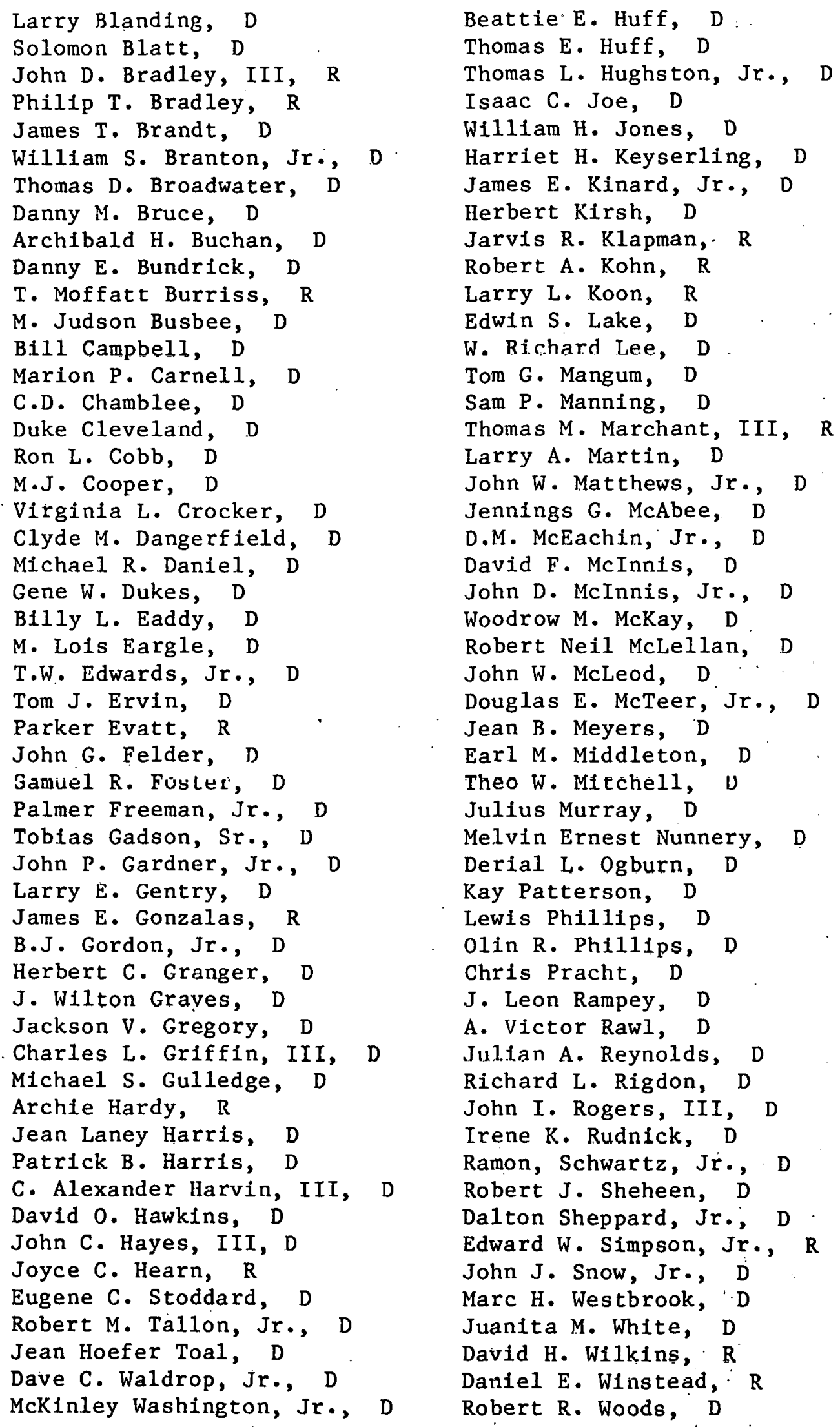

Beattie'E. Huff, D

Thomas E. Huff, D

Thomas L. Hughston, Jr., D

Isaac C. Joe, D

William H. Jones, D

Harriet H. Keyserling, D

James E. Kinard, Jr., D

Herbert Kirsh, D

Jarvis R. Klapman, R

Robert A. Kohn, $R$

Larry L. Koon, R

Edwin S. Lake, D

W. Ri.chard Lee, D

Tom G. Mangum, D

Sam P. Manning, D

Thomas M. Marchant, III, R

Larry A. Martin, D

John W. Matthews, Jr., D

Jennings G. McAbee, D

D.M. McEachin, Jr., D

David F. McInnis, D

John D. McInnis, Jr., D

Woodrow M. McKay, D

Robert Neil McLellan, D

John W. McLeod, D

Douglas E. McTeer, Jr., D

Jean B. Meyers, D

Ear1 M. Middleton, D

Theo W. Mitchell, $v$

Julius Murray, D

Melvin Ernest Nunnery, D

Derial L. Ogburn, D

Kay Patterson, D

Lewis Phillips, D

olin R. Phillips, D

Chris Pracht, D

J Leon Rampey, D

A. Victor Rawl, D

Julian A. Reynolds, D

Richard L. Rigdon, D

John I. Rogers, III, D

Irene K. Rudnick, D

Ramon, Schwartz, Jr., D

Robert J. Sheheen, D

Dalton Sheppard, Jr.; D

Edward W. Simpson, Jr., R

John J. Snow, Jr., D

Marc H. Westbrook, 'D

Juanita M. White, D

David H. Wilkins, R

Daniel E. Winstead, : R

Robert R. Woods, D 
House Leadership. The presiding of ficer of the House is the Speaker, who is elected by the members of the House. He appoints all committee members and may vote on all matters before the House. In the Speaker's absence, the Speaker Pro Tempore presides over the House. The officers of the House of Representatives are:

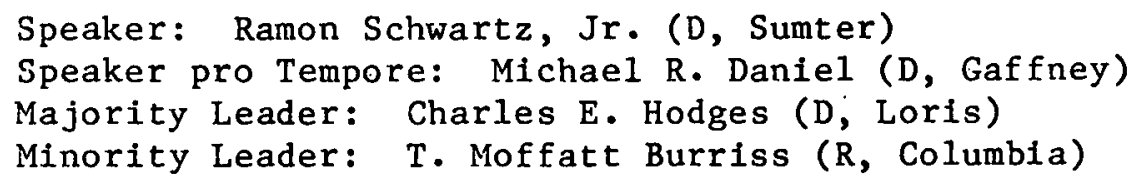

Committee Structure. There are 10 House standing committees in the 104 th General Assembly of South Carolina. Committee members are appointed by the Speaker and chairmen are elected by the members of each respective committee. Relevant House Standing Committees are:

\section{Agriculture and Natural Resources}

Chairman: John J. Snow, Jr. (D, Hem1ngway)

V1ce Chalrmen: Larry L. Koon (R, Lexington)

Wuudiuw W. MeKáy (D, Timmonsville)

Judicial, Military, Public and Municipal Affairs

Chairman: B.L. Hendricks, Jr. (D, Columbia)

Vice Chairmen: Robert L. Helmly (D, Moncks Corner)

Parker Evatt ( $R$, Columbia)

Jean B. Meyers ( $D$, Myrtle Beach)

Ways and Means

Chairman: Tom G. Mangum (D, Lancaster)

Vice Chairmen: T.W. Edwards, Jr. (D, Spartanburg)

Marion P. Carnel1 (D, Ware Shoals)

Patrick B. Harris (D, Anderson)

\section{Legislative Council}

The Legislative Council consists of the President of the Senate, Speaker of the House, Secretary of State, Chairman of the Senate Judiclary Committee, and Chairman of the House Judiciary Committee. The Council is responsible for the organization and operation of research, reference, and bill drafting services. 


\subsubsection{Judicial Branch}

South Carolina's judiclal power is vested in "a unified judicial system, which shall include a Supreme Court, a Circuit Court, and such other courts of uniform jurisdiction as may be provided for by general law" (Article V, Section I):

\section{Supreme Court}

South Carolina's Supreme Court is the highest court of the state. It comprises a Chief Justice and four Associate Justices, who are elected by the Ger:eral Assembly to 10-year terms. The Supreme Court hears appeals from the state Circuit and Family Courts.

\section{Circuit Court}

The Circuit Court is the general trial court in South Carolina. There are 16 judicial circuits within the state and each circuit has one or more judgas elected by the General Assembly to six-year terms. The Circuit Court has original jurisdiction over all criminal and civil cases. When necessary, the General Assembly may provide for additional Circuit Court Judges to be administered by the Chief Justice of the Supreme Court.

\section{Family Courts}

The Family Court system was established in 1976 and consists of one court in each of South Carolina's 16 judicial circuits. Family Court Judges are elected by the General Assembly to terms of four years. The Court has exclusive jurisdiction over all domestic relations and juvenile matters. The Chief Justice of the Supreme Court designates one judge from each circuit as Chief Fanily Court Judge. All appeals from the Family Courts are heard by the Supreme Court. 
$\underline{\text { Probate Courts }}$

Each county in South Carolina maintains a Probate Court. Probate Courts have original jurisdiction in all matters pertaining to wills and the administration of estates and in all cases of mental incompetency. Probate Court Judges are elected by popular vote to four-year terms.

\section{Municipal Courts}

Cities with a population of 1,000 or more may establish a Municipal Court. Municipal Courts have jurisdiction in criminal. matters that involve offenses against inunicipal ordinances. The Courts are presided over by Recorders who are elected by the Mayor and the Board of Aldermen.

\section{Magistrates Courts}

There are approximately 330 Magistrates Courts in South Carolina. Each Magistrate is appointed by the Governor for a term of two to four years, depending upon the county in which the court is located. The territorial, criminal, and civil jurisdiction of the Magistrates Courts vary from county to county and within counties. 


\subsubsection{Relevant Statutes and Regulations}

This section summarizes South Carolina statutes and regulations that may be relevant to low-level radioactive waste management. The full text or pertinent sections of all statutes and regulations cited in this section is conttained in the appendices.

\section{Atomic Energy and Radiation Control Act}

The Atomic Energy and Radiation Control Act designated the Department of Health and Environmental Control as the state agency with primary responsibility for the regulation and control of radiation sources. It also outlined the powers and duties of the State Development Board and the Budget and Control Board with respect to the atomic energy field. Furthermore, the Act established the. Technical Advisory Radiation Control Council and authorized the Governor "to enter into agreements with the Federal Government providing for discontinuance of certain of the Federal Government's activities with respect to radiation sources and the assumption thereof by the state toward the end of instituting and maintaining a regulatory program compatible with the standards and regulatory programs of the Federal Government and consonant insofar as possible with those of other states."

\section{South Carolina Radioactive Waste Transportation and Disposal Act. .}

The South Carolina Radioactive Waste Transportation and Disposal Act amended the Atomic Energy and Radiation Protection Act by providing for control of the transportation of radioactive waste into and within the state of Sonth Carolina. 
Regulations for Radioactive Materlals

The South Carolina Department of Health and Environmental Control has promulgated regulations for radfoactive materials pursuant to the provisions of the South Carolina Atomic Energy and Radiation Control Act. These regulations apply to all persons who receive, possess, use, transfer, or acquire radioactive materials and who are not subject to regulation by the U.S Nuclear Regulatory Commission. Contained within the regulations are standards for protection against radiation, requirements for the licensing of radioactive materials, requirements for industrial radiographic operations, and standards for the use of sealed sources of radiation in the health professions.

\section{Interim Regulations for the Transportation of Radioactive Materials} Into or Within South Carolina

Interin regulations for the transportation of radioactive materials into or within South Carolina were approved by the Board of Health and Environmental Control on May 26, 1980. These regulations apply to all persons who ship or transport radioactive waste into or within the state. They contain provisions for bonds and permits, routes, prior notification, and certification.

\section{Hazardous Waste Management Regulations}

The South Carolina Department of Health and Environmental Control has promulgated regulations for hazardous waste management. Radioactive materials, however, do not fall under the jurisdiction of these regulations. 


\subsection{Federal Activities}

There are two operating commercial power reactors in South Carolina, Duke Power and Carolina Power and Light. Both of these facilities are licensed by the U.S. Nuclear Regulatory Commission. The U.S. Department of Energy (DOE) operates four research and development and field facilities within the state: Savannah River Operations Office, Savannah River Ecology Laboratory, Savannah River Laboratory, and Savannah River Plant. The Savannah River Operations Office is a major installation in DOE's nuclear materials production anì research program. The Savannah River Laboratory, operated by E. I. DuPont de Nemours and Company, provides developmental and technical assistance in àj. facets of the nuclear fuel cycle. The Savannah River Plant, also operated by E. I. DuPont de Nemours and Company, conducts research on fuel and target fabrication, isotope production in nuclear reactors, chemical separations, waste management, and heavy-water extraction. The Savannah River Ecology Laboratory is a research facility dedicated to studying thermal energy, mineral cycling, the radioecology of transuranics, and basic and theoretical ecology

\subsection{Interest Groups}

This section identifies those parties that either have expressed or may have an interest in issues surrounding low-level radioactive waste managemert. Included are the names, special concerns, and descriptions of interesied parties within South Carolina.

\section{Palmetto Alliance}

Palmetto Alliance is a nonprofit organization that promotes the use of safe, renewable, non-nuclear energy forms. The Alliance has been involved in a continuing program to educate and organize against the nuclear industry. It 
maintains nine chapters in South Carolina. The Director is Michael Lowe.

Palmetto Alliance

$21351 / 2$ Devine Street

Columbia, South Carolina 29205

(803) 254-8132

South Carolina Environmental Coalition

The South Carolina Environmental Coalition is composed of both individual and organizational members. It is concerned with environmental issues affecting South Carolina. The Coalition publishes a quarterly journal, Coalition. The Executive Director is William Frye.

South Carolina Environmental Coalition

P.O. Box 5761

Columbia, South Carolina 29250

(803) 799-0321

\section{League of Women Voters of South Carolina}

The League of Women Voters is a membership organization involved in both energy and environmental quality programs. The concerns of the League reydiding radioactive waste are outlined in the League's "Criteria for Evaluating Suitability of Storage and Disposal Sites for Hazardous and Nuclear (Including LowLevel Radioactive) Waste." The criteria proposes a decision making process which allows for public participation, participation and review by all government levels, and procedures for mediation of intergovernmental conflict. It also states that storage or disposal of radioactive waste should not occur on or near drinking water supply sources, fraglle land areas, areas with significant renewable resource value or areas where there are rare or valuable ecosystems or geological formations.

The League's Energy Chal rwomen is:

Dr. Mary Kelly

2838 Devine Street

Columbia, South Carolina 29205

(803) 771-0063 
Environmentalists Inc.

Environmentalists Inc, is an organization composed of professionals, suct. as physicists and engineers, who are concerned with the protection of the environment, problems associated with energy use, and potential hazards of: radiation. It maintains one of the largest collections of nuclear-related documents in the country.

Envi ronmentalist, Inc.

C/o Ruth Thomas

1339 Sinkler Road

Columbia, South Carolina 29205

(803) $182-3000$

\section{Sierra Club}

The Sierra club is an environmental organization concerned with the protertion of natural resources and the maintenance of a clean environment. The $\mathrm{Di}-$ rector of the South Carolina Chapter is:

Edmund J. Scott

139 Sylvan Way

Greenville, South Carolina 29605

(803) 235-3377

\section{Audubon Society}

The Southeast Regional office of the National Audubon Society is located 1.:1 Charleston, South Carolina. All Inquiries or information concerning the Audution Society in South Carolina should be directed to this office. The Director is Carlyle Blakeney.

Southeast Regional office National Audoboin Suclety

P.0. Box 1268

Charleston, South Carolina 29402

(803) 723-6171 
Aiken Environmental Coalition

P.0. Box 1415

Aiken, South Carolina 29801

(803) 648-9806

Municipal Association of South Carolina 1213 Lady Street

P.O. Box 11558

Columbia, South Carolina 29211

(803) 799-9574

People for a Clean Environment 522 Isaqueena Trail

Clemson, South Carolina 29631

South Carolina Association of Counties 1817 Hampton Street

Columbia, South Carolina 29201

(803) 252-7255

American Civil Liberties Union

C/o Tom McAbby

Clear Towers, Apartment $\mathrm{K}$

Columbia, South Carolina

(803) 799-6309

Midlands Natural Food Growers

C/o Kenneth Kamis

3005 Blos som Street

Columbia, South Carolina 29205
Friends United For Safe Energy

C/o Acorn Natural Foods

3715 East North Street

Greenville, South Carolina 29615

(803) 244-3709

Fairfield Association

C/o Robert Guild

1314 Pall Mall Street

Columbia, South Carolina 29201

(803) 252-0929

Dr. Richard Keamy

University of South Carolina

Columbla, South Carolina 29208

(803) 777-6801

Dr. Ronald P. Wilder

University of South Carolina

Columbia, South Carolina 29208

(803) 777-6955

Richard Schartz

909 King Street

Columbia, South Carolina

(803) 799-1589

W. Elmer $\Lambda 11$ ison

Route 4, P.0. Box 391

Columbia, South Carolina 29204

(803) $776-8890$

Fairlawn Community Association

C/o Mrs. Idora K. Brown

Route 5, Box 182

Coon Store Road

Columbia, South Carolina 29203

4.6 Printed Media

A selection of newspaper articles relevant to low-level radioactive waste

management that have been published in South Carolina's newspapers during the past several years is in the appendices. 
A survey package was developed to solicit data and information necessary to characterize generally the low-level radioactive waste management practices in the State of South Carolina. The package included a questionnaire and appropriate letters encouraging licensees to participate in the survey. Administration of the survey was carefully planned to allow licensees adequate response time and included procedures for handling inquiries concerning the data requested and for performing selected follow-up telephone calls. The following sections provide specific information relative to.the survey form and administration of the survey.

\section{$\underline{5.1}$ Survey Form}

The survey form was designed to present the data requested in a concise, easily understood, yet comprehensive format. The intent was to request sufficient data to ascertain both the qualitative and quantitative nature of low-level radioactive waste management practices. The Form was designed to allow "check-off" answers wherever possible and to minimize the effort required by respondents in supplying the requested data.

The survey form proper consists of six $14 \times 81 / 2$ inch typeset printed sheets (three sheets, front and back), as shown in Figure 5.1. Licensees were informed that the data would be treated as CONFIDENTIAL and would be ANONYMOUSLY reported in consensus and statistical form. Each licensee was assigned a number, stamped on each sheet of the questionnaire." The first two digits identify the state and the last four the 1icensee. These identifying numbers were used during data processing for control purposes. 
Sheet One of the questionnaire contains introductory statements consisting of a Rationale for Study and General Guidelines for completing the form. The first four sections, also a part of sheet one, request the following information:

\subsection{Organization and Facility Data \\ 2.0 Type of Facility \\ 3.0 License Information \\ 4.0 Radioactive Waste Information}

Section 4.0 asks a simple yes or no question about whether the facility generated and/or received radioactive waste during 1978, 1979 and/or 1980. Respondents answering No for each year were informed that they had completed the questionnaire and were asked to return it.

Sheet Two consists of Section 5.0, Use Classificatinn for Unsoalod Radioactive Sources, and Yearly Data Sheet Instructions. The instructions require the use of a key for completing the yearly data sheets. The key contains multiple answers to certain questions and the respondent had only to select the appropriate corresponding number.

The Yearly Data Sheets for 1978, 1979, and 1980 comprise sheets Three through Five. These sheets solicit data in matrix format of radionuclides versus characteristic and quantitative data in six (6) general categories. The categories are the same for each Yearly Data Sheet, except they were sequentially numbered from 6.0 through 23.0 for processing purposes. The categories are:

$6.0,12.0,18.0$ Radionuclides Received/Produced

$7.0,13.0,19.0$ Radioactive Waste Generated 


$$
\begin{aligned}
& 8.0,14.0,20.0 \text { Radioactive Waste Received } \\
& 9.0,15.0,21.0 \text { Radioactive Waste Processed/Reduced } \\
& 10.0,16.0,22.0 \text { Radioactive Waste Shipped } \\
& 11.0,17.0,23.0 . \text { On Site Waste Disposal }
\end{aligned}
$$

Sheet Six contains Sections 24.0 and 25.0 , which inquire about the source(s) of radionuclide production and facility(ies) from which radioactive waste was received, and a comments and remarks section. This section allows the recipient of the survey to make suggestions or indicate any difficulties encountered that may have effected a particular response.

Some requests for information are included as part of the questionnaire for the sole purpose of determining the validity of other data collected. For example, the type of monitoring instrumentation that a- repondent uses to collect activity data reveals the accuracy with which the data was obtained.

\subsection{Survey Administration}

Mailout packages were prepared that included a questionnaire, a self-addressed prepaid return envelope, a letter from Vachon, Nix and Associates, and a letter from Mr. Heyward G. Shealy, Chief, Bureau of Radiological Health, South Carolina Department of Health and Environmental Control. The Vachon, Nix and Associates letter and state letter included in the packages are presented as Figures 5.2 and 5.3 .

Names and addresses of those licensed to handle radioactive material in the State of South Carolina were obtained from EG\&G Idaho, Inc. EG\&G provided a list of U.S. Nuclear Regulatory Cominission licensees. No attempt was made to differentiate between those licensees believed not to 
generate radioactive waste and those known to generate waste. Survey packages were mailed to every nane provided.

Large $71 / 2 \times 101 / 2$ inch envelopes were specifically used for the mailout so that the package would not be easily misplaced by recipients. Two special notices were printed on the envelopes: 1) DATED MATERIAL: Southern States Energy Board Radioactive Waste Management Survey, and 2) ATTN: Radioactive Material Control officer.

The packages were mailed first class on April 23, 1981, and a sample package was subsequently mailed to Mr. Shealy. Figure 5.4 is the letter of transmittal to him. After approximately two weeks had elapsed, follow-up telephone calls were made to selected licensees. Figure 5.51 s a copy of a standard form that was developed to record inquiries from licensees as well as follow-up contacts.

June 15 th was established as a cut-off date for processing questionnaires. Questionnaires received after that date were monitored for the purpose of sorting out significant "waste generators." The results of the survey are presented in Chapter 6 . 
Figure 5.1

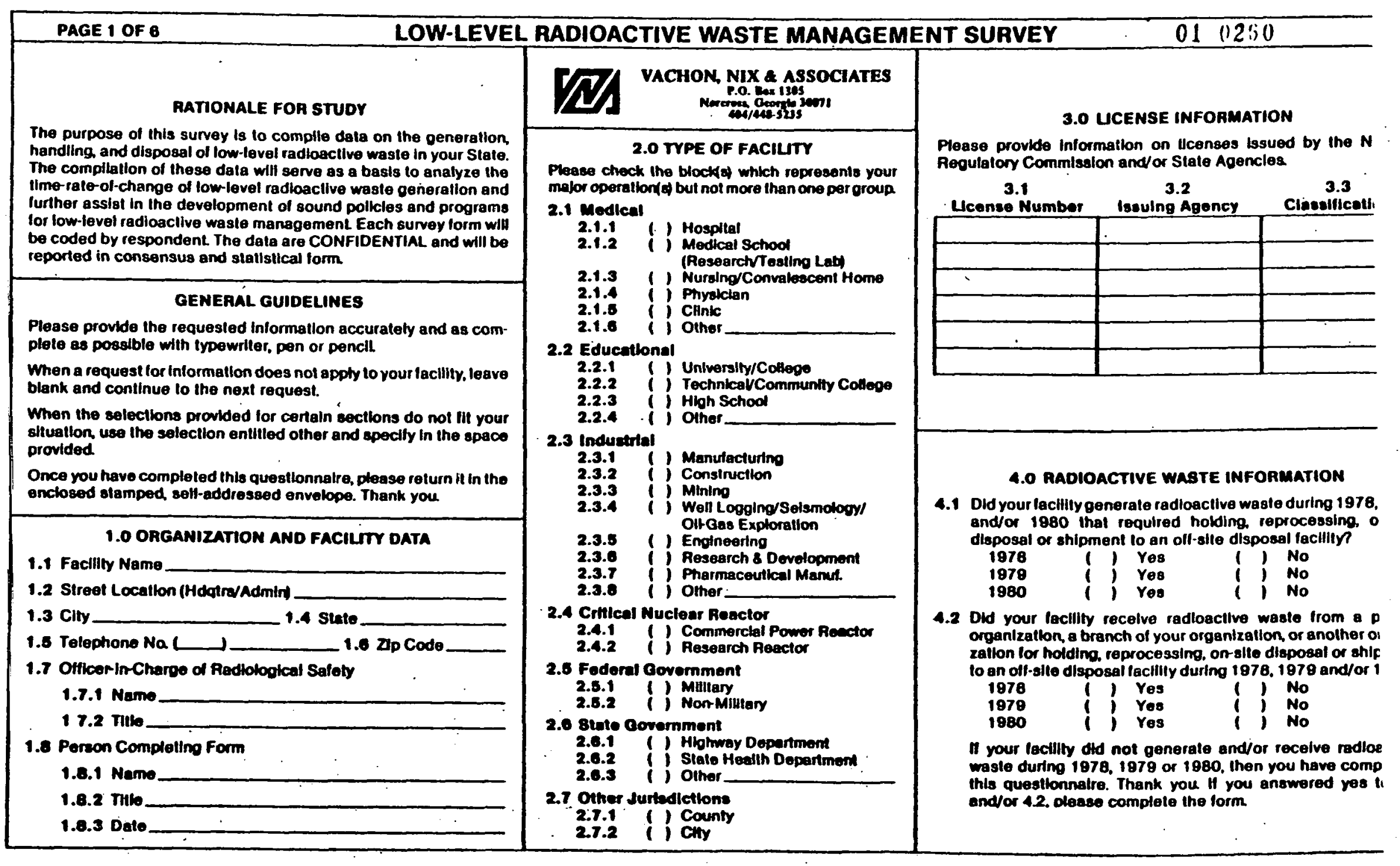




\subsection{USE CLASSIFICATION FOR UNSEALED RADIOACTIVE BOURCES}

Please Indicale the percentage of total volisme of unsealed radloaclive matertal used for each calegory below Total of all calegorles should equal 100\% E.t Human
5.1 .1
() Diagnostic
Son-Dlagnostte
() Resenich
5.2.1 ( ) Dlagnostic
5.2.2
6.2.3 if Research
5.3 Goneral Reseorch

5.3.1 () Physical
5.3.2 () Chemical
5.3.3 () Englneering
5.3.4 () Other

8.2 Antmal
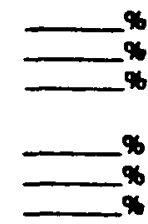

Total of 5.1, $5.2 \& 5.3$

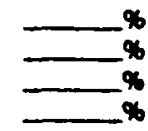

$100 \%$ (Spectiy)

VEARLY OATA SHEET INSTRUCTIONS

The following data shests request Information on radionuclides (tsotopeditrecelved andvor produced and radbectlve wasle gerierated, recelved, processed shloped and dtaposedi of onstite for calendar years 1878, 1979 \& 1880

The shoets are identical in format. As a comentence, a list of common redtonucildes has boen provided Please report data as requested for all radlonuctides hendied by your factity. All quantlialive date should be laken directly from lectilty recorde records ere not avallabta, please estimate answers as accurately as posslbte.

reconds are not avallabta, please estimate answers as accurately as posaltib. materlals to be used at your lacilty. The term" 12.0818 .0 refers to radioactive emitling materiais to bo used at your lacilty. The term "Weoto" as used in Sections P. O-11.0, 13.0 17.0 2 18.0-23.0 refors to ali radioectro omiling materlals that have no further wes at your factily and muat be ehther disposed of on-site or transported to another lacility. "Waste Generated" In Sectlons 7.J, 13.08 18.0 relers to that genereted at your facility while "Weste Fecerved" in Sections 8.0, 14.0820 .0 refers lo waste recetved from other fecilitios. In Sections 8.0, 16.0 \& 21.0 entitiod "Waste Procesend/Aeduced", the column labeled "ap" refers to percent reduction from the ortoinal volume to the reduced votume. The columns labeled A thru H on ezch sheet requite the use of the key provided on this pege for completion Please salect the aporoarice answer irom this koy and insert the comesponding number s in the space providod lor each radionuclide.

To insure eccurate compllation pleses report data in accordance wth the units Mated Thank you very much for your cooperalion space for addilional comments is provlded on page six

KEY FOA COMPLETING

YEARLY DATA SHEETS

\section{SECTIONS 9.0,15.08 21.0}

(A) REDUCTION PROCESS

1 = Compaction

2 = Solldification

3 = Evaporation

4 = Adsorption (Ion Exchange)

$5=$ Absorplion

$8=$ Incineration

$7=$ Other

SECTIONS 10.0,11.0, 15.0, 17.0,22.0823.0

[B] WASTE FOAM

$$
\begin{aligned}
& 1 \text { = Dny Sollo(s) } \\
& 2 \text { = Solld Llquid(s) } \\
& 3=\text { Nonsolld Llquidist } \\
& \text { = Scinilitation Vlals } \\
& 6=\text { Blological } \\
& 6 \text { = Gaseous } \\
& 7 \text { = Sealed Source } \\
& 8=\text { Other }
\end{aligned}
$$

SECTIONS 10.0, 18.08 22.0

[C] SHIPPING CONTAINEA

$$
\begin{aligned}
& 1=\text { Kraft Container } \\
& 2=55 \text { Gallon Drum } \\
& 3=30 \text { Gallon Drum within } \\
& 55 \text { Gallon Drum }
\end{aligned}
$$$$
4=\text { Other }
$$

SECTIONS 10.0, 16.0822 .0

(D) ADDITIONAL HAZARD POTENTIALS

$$
\begin{aligned}
& 1=\text { Corrostve } \\
& 2=\text { Toxtc } \\
& 3=\text { Flammable } \\
& 4=\text { Votatlie } \\
& 5=\text { Explosive } \\
& B=\text { Olher }
\end{aligned}
$$

\section{SECTIONS 10.0, 16.0 22.0}

[E] DESTINATION

IA = Barnwet, Soulh Carolina $18=$ Beally, Nevide

1C = Richland (Hanford), Washim $\mathrm{ID}=$ OIher

$2=$ Distribution In Product Forn

3 = Relum to Vendor

$4=$ Olher

\section{SECTIONS 10.0, 16.08 22.0}

[F] TRANSPORT METHOD

1 = Facilily Truck

2 = Molor Express

$3=$ Alr

$=$ Rail

$5=$ Other

SECTIONS $11.0,17.0823 .0$

[O] METHOD

$1=$ Relesese 10 Sewer

$2=$ Combine with Common Refur

$3=$ Incinerate to Atmosphere

4 = Evaporate or DistilI

5 = Vent to Almosphero

$6=$ Bury On Site

$7=$ Redisistbule to Facility Users

in Orbinal form

8 = Other

(H) MONITORING INSTRUMENTATIO 1 = Ion Chamber

$2=$ Thermoluminescent Dostmett $3=$ End Window $>1.4 \mathrm{mgm} / \mathrm{cm}^{2}$ Gelger-Muetder

$4=$ Thin Window $<0.5 \mathrm{mgm} / \mathrm{cm}^{\prime}$ Gelger-Muelder

5 = Gas Proportional Counter

$6=$ Ltauld Sctnitiation Spectrom

$7=$ Eloctron Caplure

$8=$ Other 


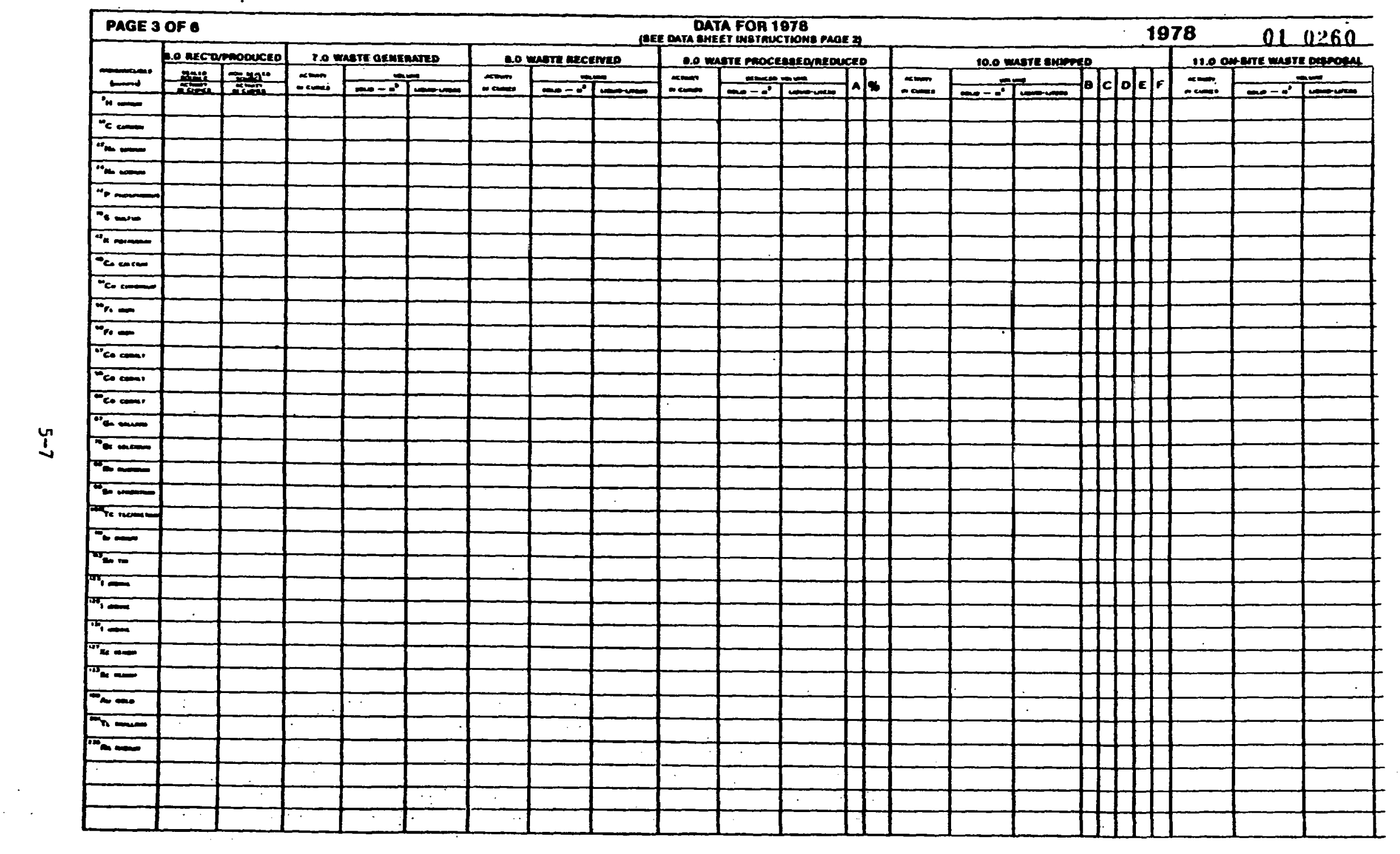




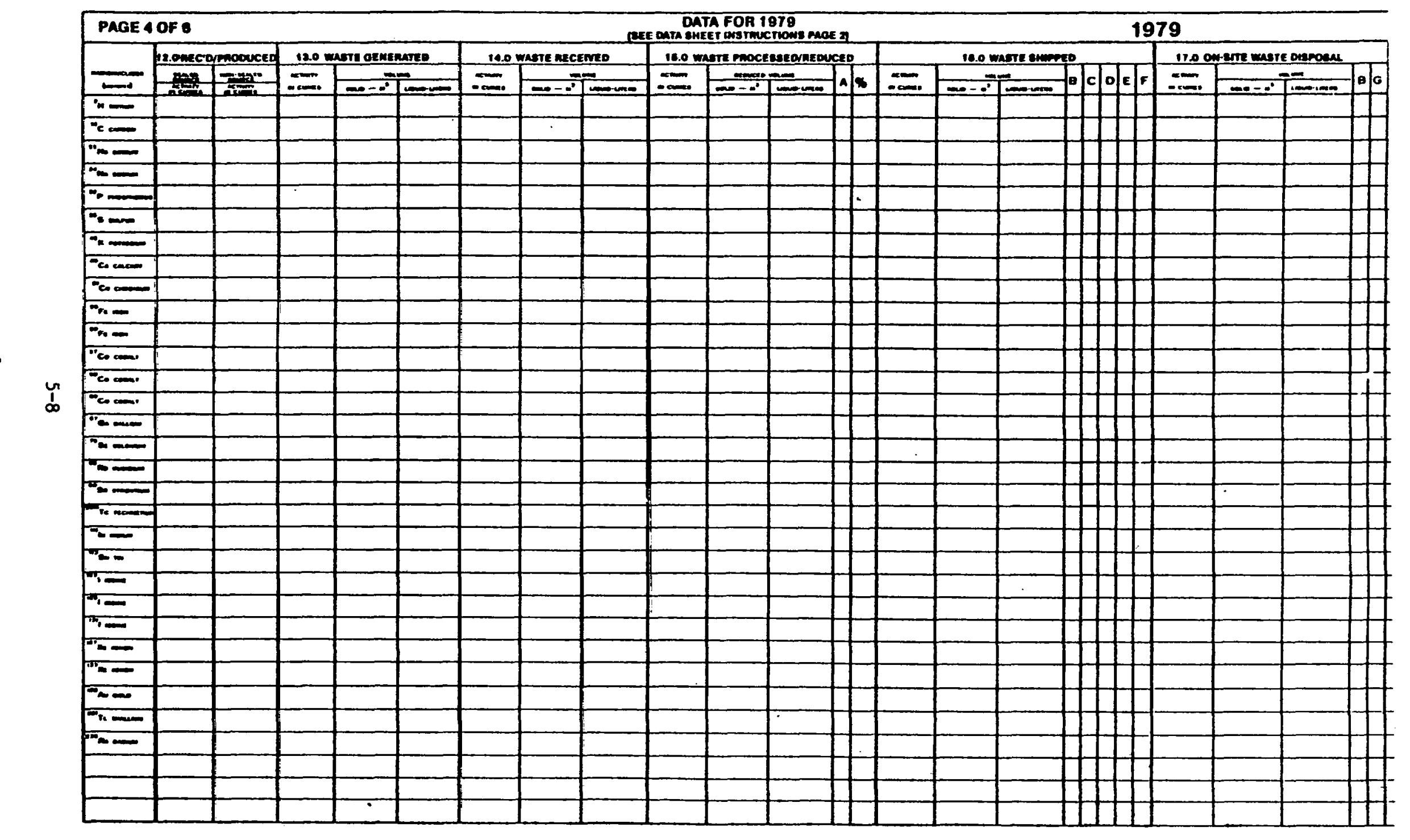




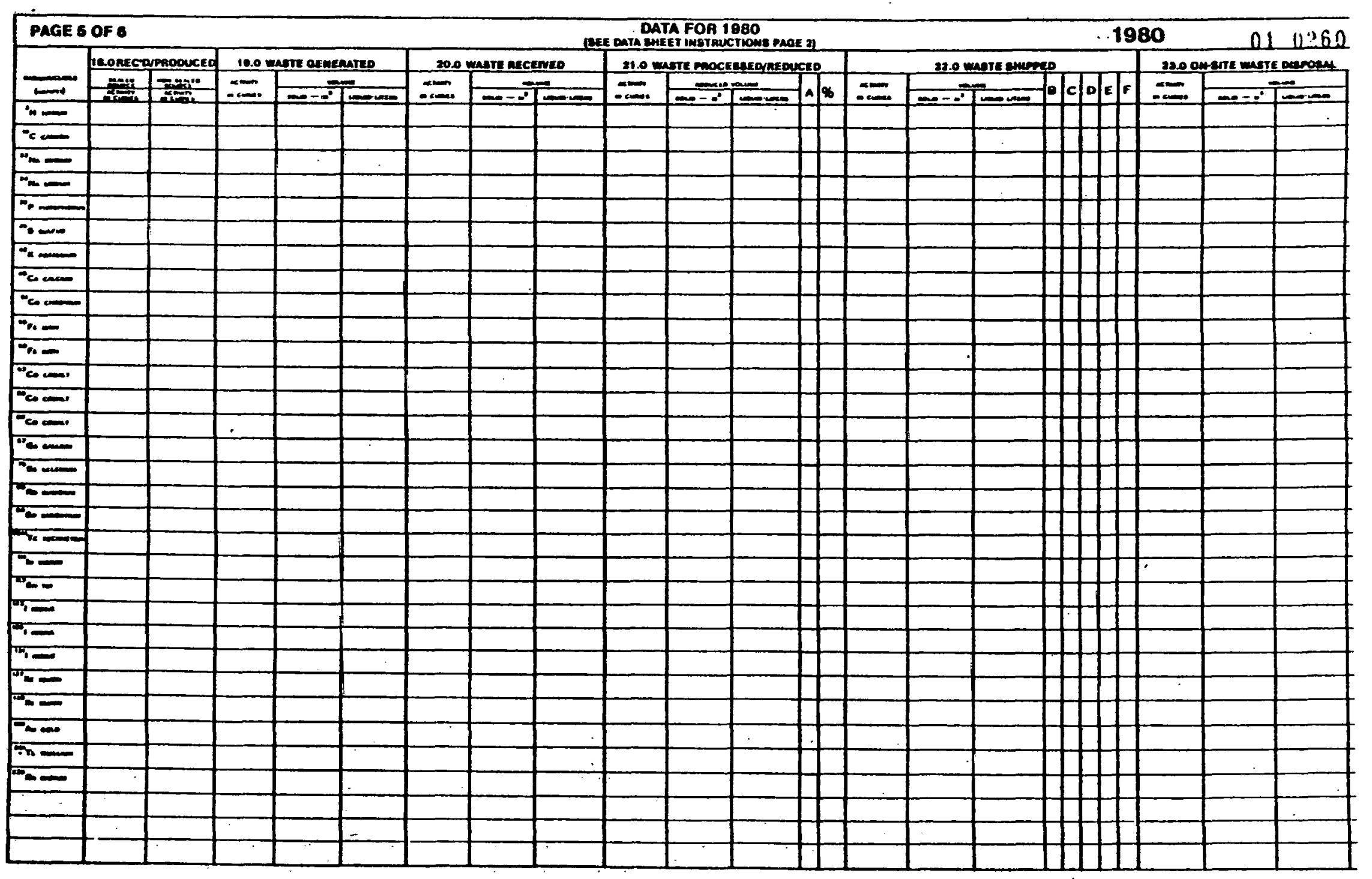


PAOE G OF .

24.1 8ubcritical Rosctor

24.2 Critient Reactor

24.3 Power Reactor

24.4 Crelotron

24.5 Unear Accelorator

24.8 Meutron Genormtor

24.7 Bynchrotion

24.8 Van de Oranft Conerntor

24.9 other

24.10 Other

24.11 Other

\section{LOW-LEVEL RADIOACTIVE WASTE MANAGEMENT SURVEY}

24.0 SOURCE(S) OF RADIONUCUDE PRODUCTION

\begin{tabular}{|c|c|c|c|c|}
\hline $\begin{array}{l}\text { POWERYIUX } \\
\text { LEVEL }\end{array}$ & $\begin{array}{l}\text { PNOLONCTIVE } \\
\text { SOURCE }\end{array}$ & $\begin{array}{c}\text { ACTMITY } \\
\text { IN CUAIES }\end{array}$ & MODERATOA & MNNUFACTURER \\
\hline & & & & \\
\hline & & & & \\
\hline & & & & \\
\hline & & & & \\
\hline & & & & \\
\hline & & & & \\
\hline & & & & \\
\hline & & & & \\
\hline & & & & \\
\hline & & & & \\
\hline & & & & \\
\hline
\end{tabular}

25.0 FACIUTY(8) FROM WHICH RADIOACTIVE WASTE WAS RECENED

26.1

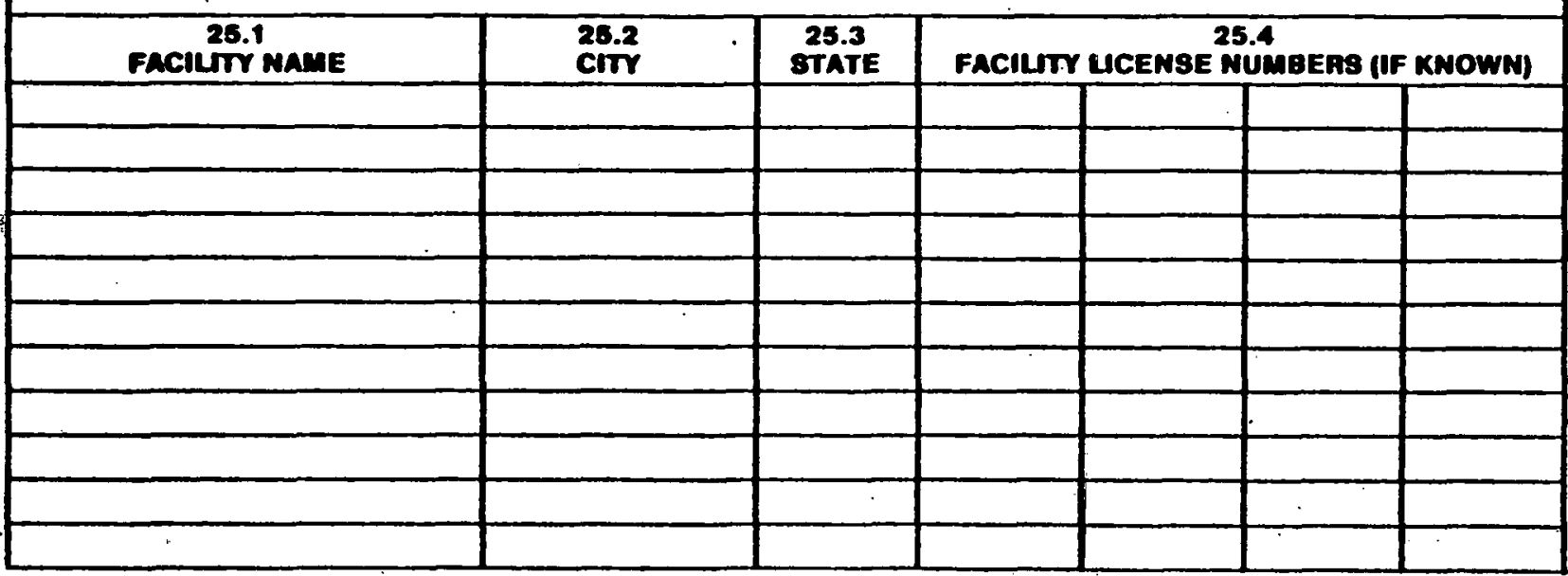

Commonts \& Romarke by Reepondent: 
SUBJECT: Loiv-Level Radioactive Waste Managenent Survey

Dear Licensee:

VACHON, NIX AND ASSOCIATES and the SOUTHERN STATES ENERGY BOARD, under a U.S. Department of Energy Contract, are developing State Brfefing Books on Low-Level Radfoactive Waste Management Issues. This project is being conducted with the encouragement of your State Radiologtcal Control Officer as Indicated by the attached letter. We need your help to ensure that your State issues are presented correctly. Thus, we ask you to provide us with data on the generation, handling and disposal of lowlevel radioactive wastes relative to your factifity.

The enclosed questionnatre and return envelope are designed to help you provide these data. Please complete the form and mall to us within seven (7) days. I am sure you share ny dislike for filling out forms. However, in this case we will be working together to ensure the safe and continued use of radioactive materials.

As soon as the project is completed for the twelve-state area of our survey, we will send the results to each of the states. Your State Radiological Agency will share the results with you.

Your facility will remain anonymous and data provided will be CONFIDENTIAL and reported in consensus and statistical form.

Thank you for your time and interest. Please call us at (404)448-5235 if you need assistance with the questionnaire, wish to ask questions or make specific comments relative to the project.

Cordially,

VACHON, MIX \& ASSOCIATES

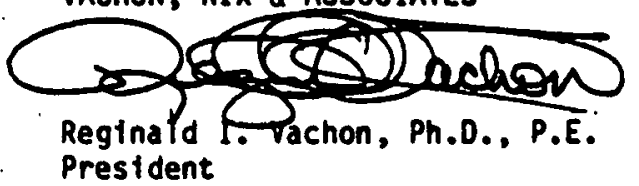

RIV/caw 


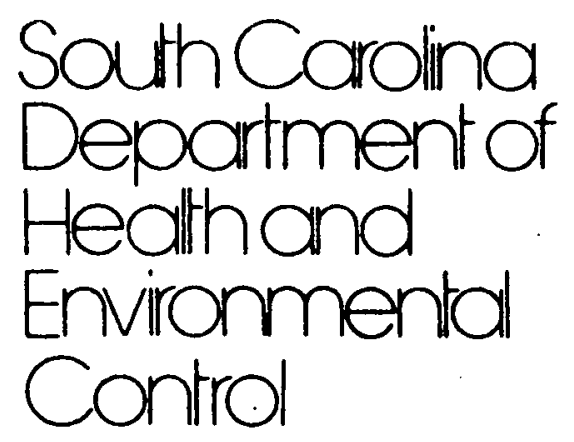

BOARD

Willam M. Wilson, Chairman

J. Lorin Mason. Jr., M.D., Vko-Chairman Leonard W. Douglas, M.D., Secretary Moses H. Clarkson, Jr. George G. Graham, D.D.S. Barbara P. Nuessle

COMMISSIONER

Robert S. Jackson, M.D.

2600 Bull Street Columbia, S.C. 29201

Apri1 21, 1981

\section{MEMORANDUM}

T0: Al1 Radioactive Material Ljcengees

FROM: Heyward G/fhichly, thief fecty

Bureau of Radiological Health

SUBJECT: Low-Leve1 Radioactive Waste Management Survey

The U.S. Department of Energy is conducting a survey of all radioactive material 1 icensees in South Carolina. The purpose of this survey is to determine the amount and types of low-level radioactive waste generated in South Carolina and the current storage and disposal practices in connection therewith.

This survey will provide information for DOE's National Low-level Radioactive Waste Management Program. Your participation in this survey is strictly voluntary, and is not a requirement of the Department. However, your cooperation in this endeavor will be gratefully appreciated.

If you have any questions concerning this survey, please contact the persons designated in the accompanying instruction letter.

HGS:kn

Figure 5.3 


\section{VACHON, NIX \& ASSOCIATES}

April 28, 1981

Mr. Heyward G. Shealy

Cheif

Bureau of Radiological Health

Dept. of Heal th \& Environmental Control

2600 Buil st.

Columbia, South Carolina 29201

Dear Mr. Shealy:

VACHON, NIX \& ASSOCIATES and the SOUTHERN STATES ENERGY BOARD appreciate your assistance to our project of developing a Briefing Book on Low-Level Radioactive Waste Management Issues for ithe state of South Carolina.

I have enclosed a copy of the survey package which is being mailed to all South Carolina Licensees today. This package includes your letter, a letter from VNA and the Low-Level Radioactive Waste Management Survey Form. After an elasped period of eleven (11) days, follow-up phone calls will be made to selected non-respondents. Afterwards, twelve (12) days will be allowed for final response. Responses received after May 20 may not be included in data processing due to contractural time restraints.

Thanks again for your cooperation. If I can answer any questions, please call me at (404) 448-5235.

Cordially,

VACHON, NIX \& ASSOCIATES

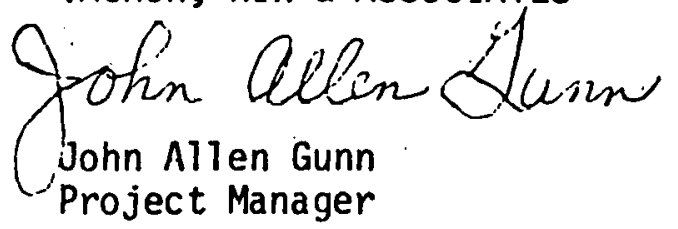

JAG/caw

Enclosure 
STATE CODE :

SERIAL NO:

DATE FORM MAILED:

DATE FORM RECEIVED:

DID FACILITY GENERATE AND/OR RECEIVE RADIOACTIVE WASTE DURING 1978, 1979 AND/OR 1980?

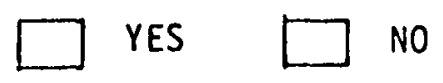

Inquiry From:

Date:

Received By:

Phone \#:

Type of Inquiry:

Letter

Phone

Questions:

Answers:

Action Items: Action Taken By:

Date:

Telecon Follow-Up By:

Date:

Telecon With (Name):

Phone \#:

Questions:

Answers:

Action Items: Action Taken By:

Date:

Figure 5.5 
The purpose of this study was to compile data on the generation, handling, and disposal of low-level radioactive waste in the state of South Carolina. A total of 365 licensees were Identified as producers or users of radioactive materlals in the state. The licensees range from an individual physiclan to a nuclear power generating plant. Each licensee was sent via the U.S. Postal Service a packet containing the "Low-Level Radioactive Waste Management Survey" and other Information as explained in Chapter 5.0. Figure 5 is a copy of the survey.

Compilation of the data generated by the survey is reported in Tables 6.1 through 6.13. Respondents to the survey were Identified by one of the following seven broad categories: (1) Medical, (2) Educational, (3) Industrial, (4) Critical Nuclear Reactor, (5) Federal Government, (6) State Government, and (7) Other Jurisdictions (political subdivisions). Data in each of the above tables are presented for each category. A large number of respondents chose to identify multiple operations within a category. Thus, it is impossible to correlate between tables. Error analysis programs corrected for this problem wherever and whenever possible, but data presented in each table should be treated independent1y.

Two basic types of tables are presented, one revealing qualitative and quantitative data and the other revealing only qualitative data. The first table presents information on quantity of waste shipped by category and 1ndividual 1sotope. The latter presents information on type of container used for shipping, frequency of shipments containing hazardous materials, and techniques for volume and activity reduction. 
hazardous materials, and techniques for volume and activity reduction. Table 6.14 provides a forecast for low-level radloactive waste based on the IImited Information produced by this study. Additional studles covering a minimum of 10 years and a higher response rate would be necessary to add the desirable credibility to the forecast. 


\subsection{Summary}

of the 365 licensees, 96 (26.30 percent) responded to the survey. of the 96 responding, 65 percent reported no waste generated and 35 percent reported both generation and shipment of low-level radioactive waste.

The total millicuries of low-level radioactive waste reported shipped during 1978, 1979, and 1980 was $34,176,19,428$, and 117 .

The major limitation of this study is the large number of licensees who falled to return the survey. Another IImltation is the small percentage of licensees who indicated that they generated and/or received waste but considered the information proprietary and did not report data for their facility. A final limitation of this study is the failure to respond of licensees who are known to manufacture and/or fabricate devices or iteiús cuntalning radioactive materials or devices capable of producing lonizing radiation that could generate nuclear waste. 
Table 6.1 Respondents Reporting Nuclear Waste

Table 6.1 represents only those respondents to the survey who reported shipping nuclear waste in one or more years of the study period (1978, 1979, and 1980). The categories of facilities are the same. The numbers reported in the Total Column represent the total number of licensees reporting shipping nuclear waste. Percentages were computed for each category to equal 100 percent. When a specific category was not reported by any licensee, a 0 is shown for that particular category. 
TAELE 6.I RESFONDENTS REFORTING NUCLEAR WASTES IN SOUTH CAROIINA

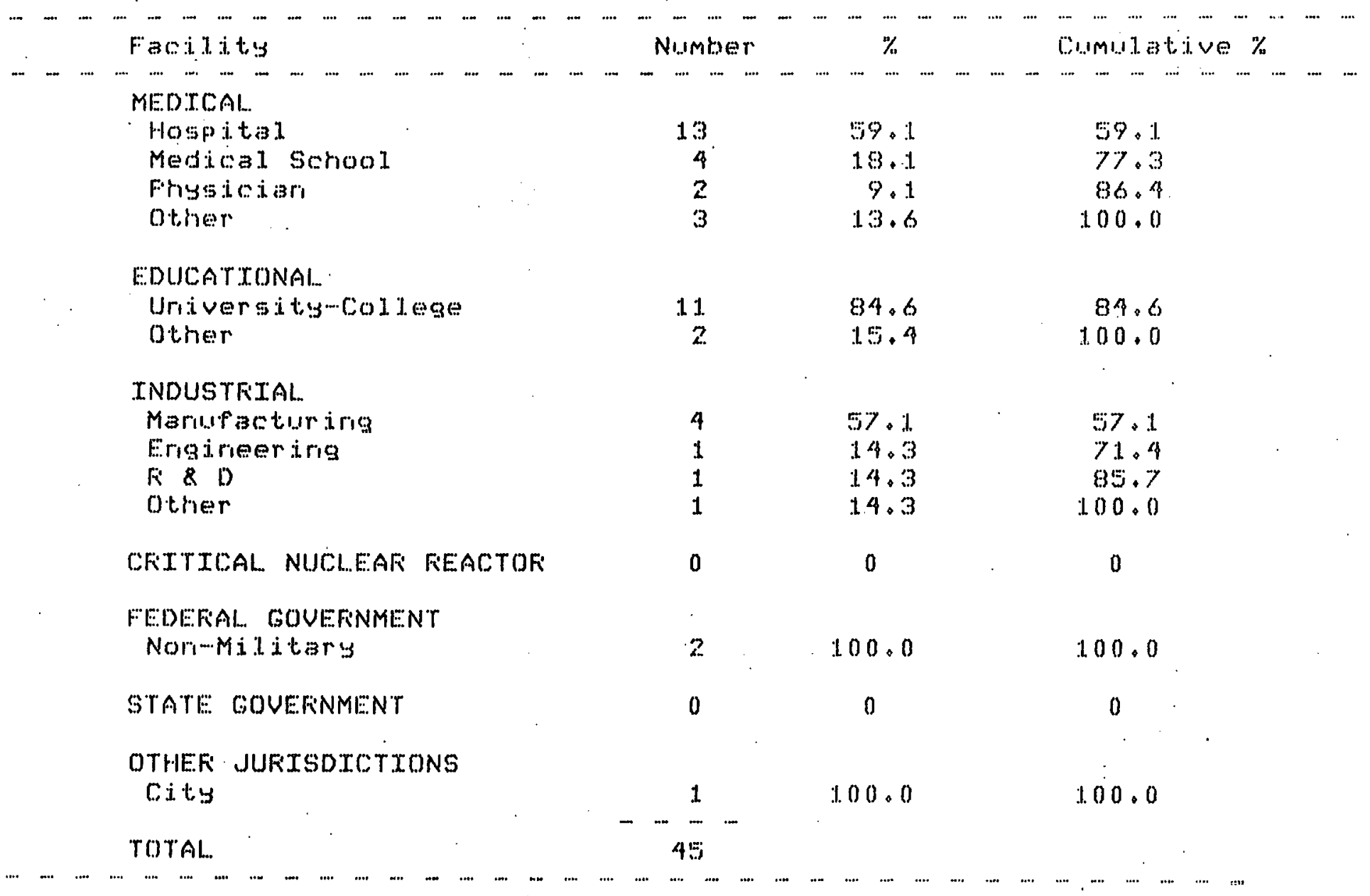


Table 6.2 Respondents Reporting Use of Sealed Sources Not Producing Nuclear Wastes

Table 6.2 represents those 11 censees using nuclear materials in the form of sealed sources who reported not shipping nuclear waste during one or more years of the study perlod (1978, 1979, and 1980). The categorles of factlities are the same. The numbers reported in the Total Column represent the number of licensees reporting not shipping nuclear waste. Percentages were computed for each category to equal 100 percent. When a specific category was not reported by any licensee, a 0 is shown for that particular category. Examples of Sealed Source devices were Strontium-90 eye applicators (Physicians); Radium-226 needles (Phys1clans); Irridium-192 (Manufacturing; Well-Logging and State Governments); Cobalt-60 (Manufacturing); and Cesium-137 (Manufacturing). 
TARLE 6.2 FESFONDENTS REFOFTING USE OF SEALED SOURCES NOT FFODUCTNG NUCLEAR WASTES FFOM SOUTH CAFIOLINA

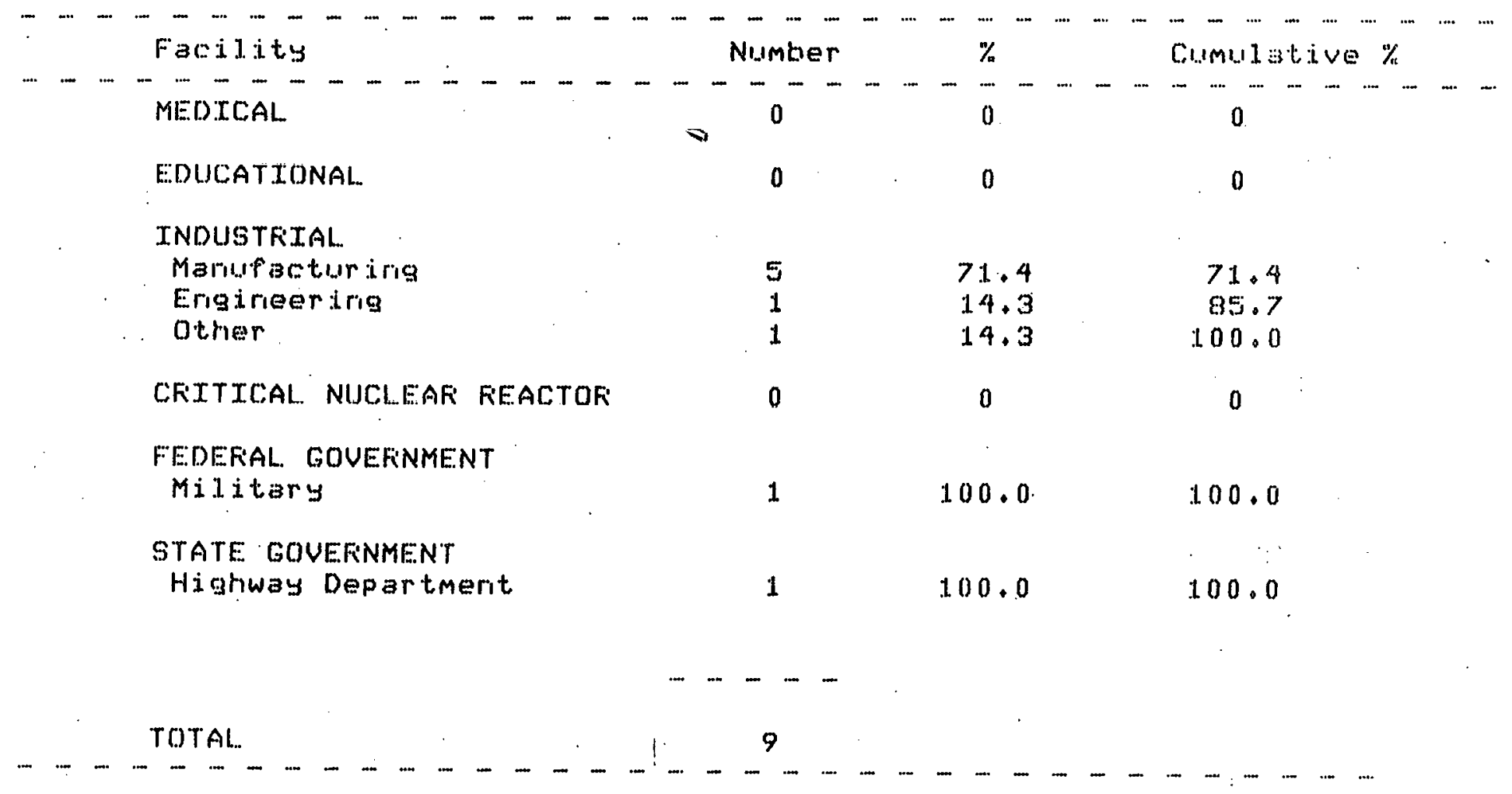


Table 6.3 Respondents Reporting No Waste

Table 6.3 represents those 1icensees using nuclear materials who reported not shipping nuclear waste during one or more years of the study period (1978, 1979, and 1980). The categorles of facillties are the same. The numbers reported in the Total Column represent the number of Ilcensees reporting not shipping nuclear waste. Percentages were computed for each category to equal 100 percent. When a specific category was not reported by any licensee, a 0 is shown for that particular category. The numbers reported in this table represented all licensees from all categorles. 
TAELE 6.3 FEESFONDENTS FEFOFTING NO WASTE IN SOUTH CAFOL INA

Facilitity

MEITICAAL.

Mospitial.

Merical School

Fhysicion

other

EDUCATIONAL.

Uiviversitis/Colloge

Techrical/

Comm. College

otiner

INDUSTRIAL.

Manusacturing

Construction

Mirijig

Well logging/

Seismology/

oil-gas exploriation.

Engirieeririg

Fi \& D

other

CFITITCAL -NUCLEAF FEACTOF

Commerciaj. Fower fieacotor

FEDERAL COUIFENENT

Non...Mi ilitiary

STATE GOVEFINMENT

Hi. griway Departmerit

Health Departimerit.

other

DTHEF JUFISDTCTIONS

compitis

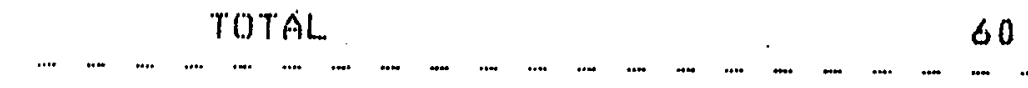

\section{Nimber}

\section{6}

1

3

3

3

1

2

12

1

1

1

4

2

6

1

2

1

3

5

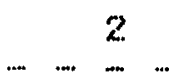

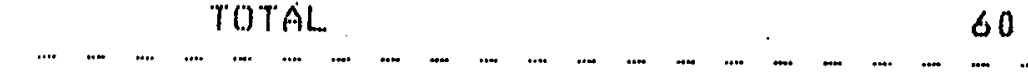

$\begin{array}{rr}46.1 & 46.1 \\ 7.7 & 53.8 \\ 23.1 & 76.9 \\ 23.1 & 100.0\end{array}$

50.0

50.0

$66+7$

100.0
44.4

48.1

51.8

3.7

3.7

3.7

14.8

7.4

$2.2 \cdot 2$

50.6

70.4

77.8

100.0

100.0

(1) 0.0

100.0

100.0

1.1. 1

1. I. . I

33.3

59.5

44.4

100.0 
Table 6.4 Sealed Sources Producing Sh1pped Nuclear Waste

Table 6.4 represents those respondents to the survey who reported using nuclear materlals as sealed sources and produced nuclear waste that was shipped during one or more years of the study period (1978, 1979, and 1980). The categorles of facllities are the same. The numbers reported in the Total Column represent the number of 11censees reporting shipping nuclear waste. Percentages were computed for each category to equal 100 percent. When a spectfic category was not reported by any licensee, a 0 is shown for that particular category. The respondents represented in this table were from the Medical and Industrial categories. Devices using Irridium-192 or combinations with other 1sotopes were used at the 11censee's site unt1l a marked specific nuclear activity dropped. This usually took place between six months and a year. When the activity was sufficlently low to interface with the device, the licensee shipped it to the original manufacturer-fabricator for a new sealed source in accordance with the 11censee's author1zed specific nuclear activity. The survey indicates that several users of these types of devices repeated the proress of packing and ohipping the source for another after decay as many as four times in the threeyear perlod covered by this study. Those who responded by answering the appropriate questions on the survey form Indicated that the sources were sent to manufacturer-fabricators in Loulsiana and North Carolina. others responding did not indicate the location of the manufacturerfabricator. Other sealed sources Included Cobalt-60 and Radium-226 which were shipped for disposal. 
TAEIE 6. 4 SEALED SOUFCES FFODUCING SHTFFED NUCLEAE WASTE FOR SOUTH CAOLINA, LIY7\%

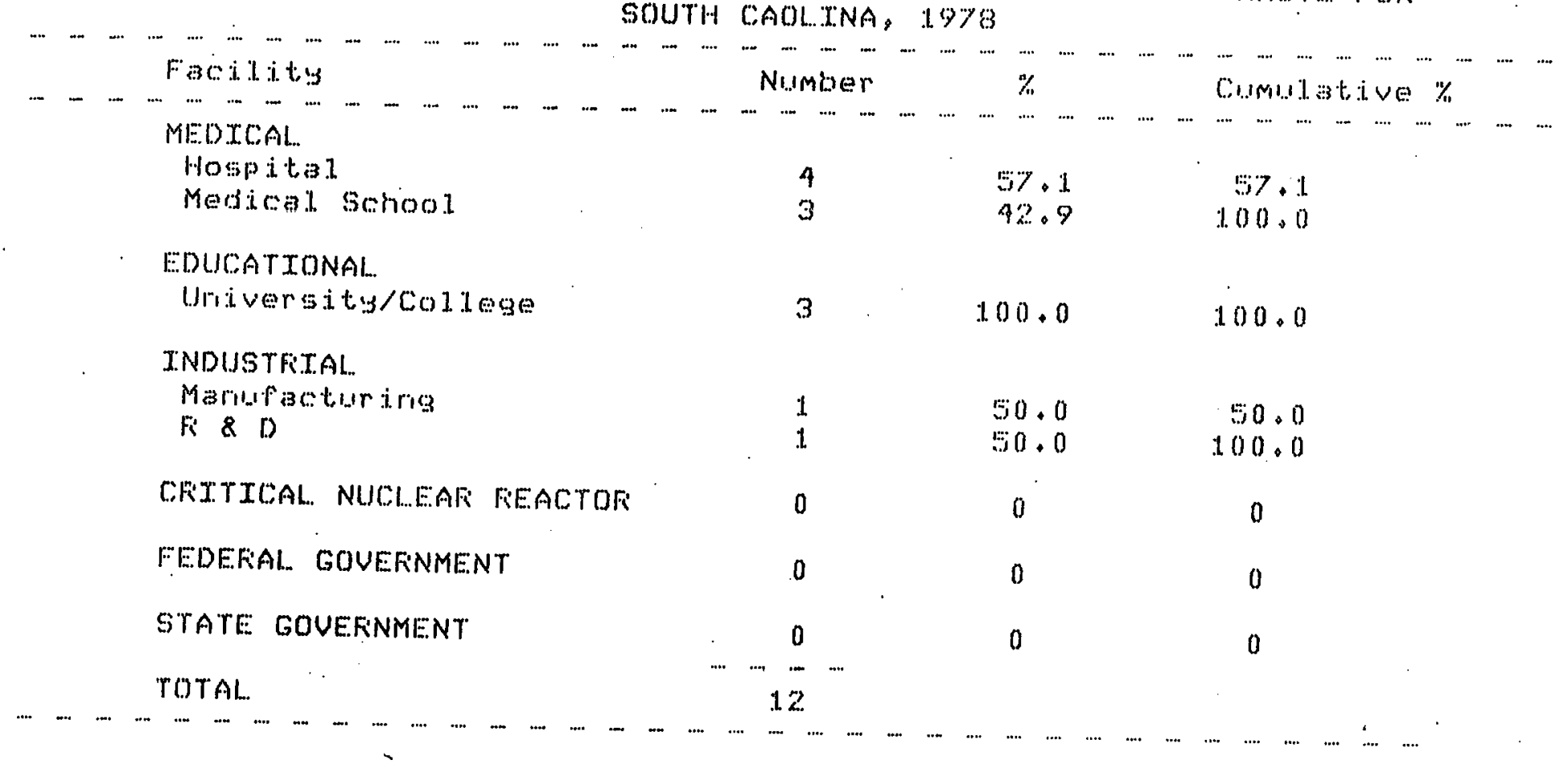


TAELE: 6.4 SEALED SOUFCES FRODUCRNG SHTFFED NUCLEAR WASTE FOR SOUTH CAFELLNA, 1979

Fasilitis MEDTCAL. Hosp it t.:3. 1. Medical School

EEDUCATTONAI..

Uriversitis/colitege

INDUSTHXAL.

CFTYTCALI. NUCIEEAF REACTOF

FEDEEFAI... COUEFNMENT

STARE COUEFINMENT

TOTAL.. Number 4

3

$57 \cdot 1$

42.9

57.1

100.0

3

100.0

100.0

0

0

0

0

0

0

0

0

0

0 .

-...

10 
TAELE 6.4 SEALED SOUFCES FFODUCING SWTWED NUCIEAF WASTE FOR SOUTH CAROLINA, 1980

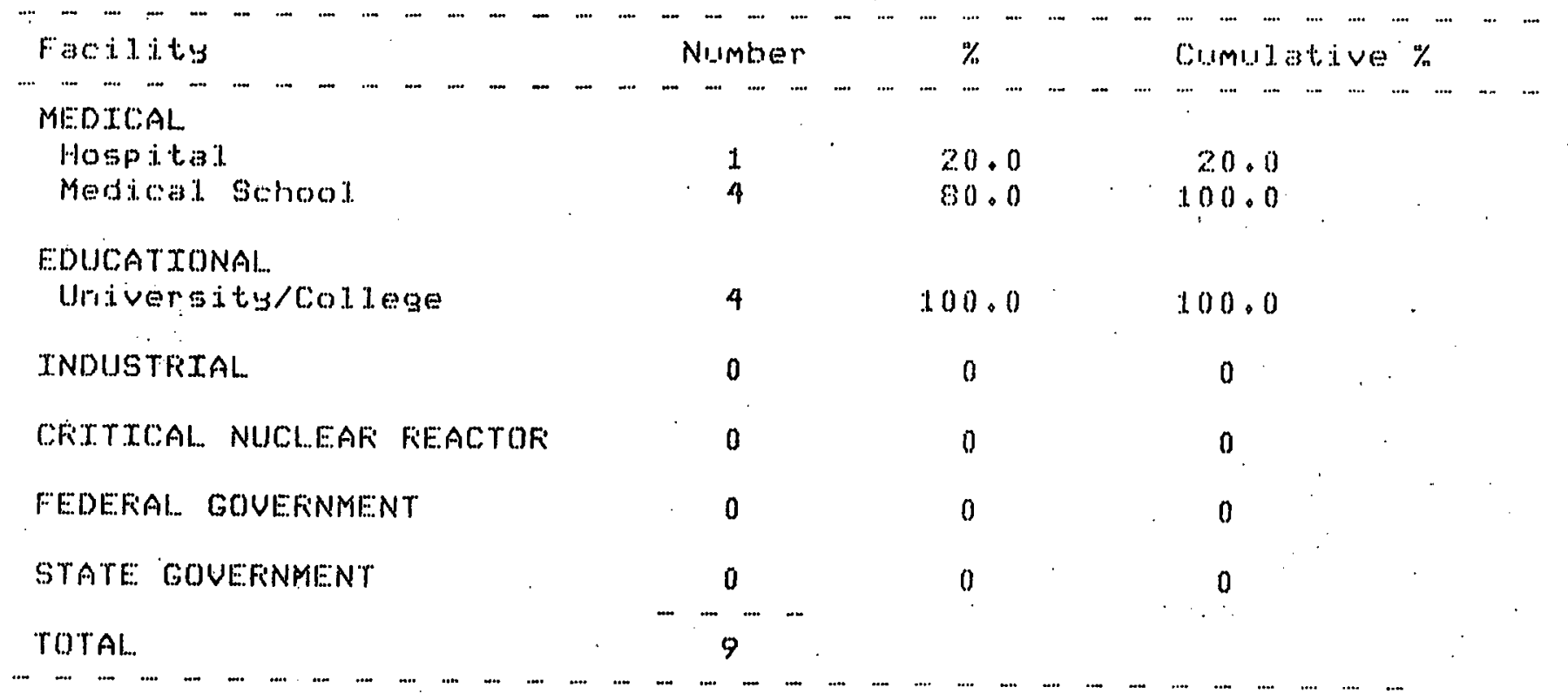


Table 6.5 Millicurles of Nuclear Waste Sh1pped by Facility Type

Table 6.5 represents those respondents to the survey who reported shipping nuclear waste produced from all sources and categorles during one or more years of the study perlod $(1978,1979$, and 1980). The categorles of faclifties are the same. The numbers reported in the Total Column represent the number of millicuries reported shipped. When a specific category was not reported by any licensee, a 0 is shown for that particular category. Each 1sotope reported on pages 3, 4, and 5 of the survey was included in this table. Isotopes and totals for the three years are shown in mililcurles. By using a validation program, multiple reporting of the same 1sotope and quantity has been corrected In the totals; $1 . e .$, respondents were found to report duplicated data. In both the Medical category and Educational categories. 
TAELE 6.5 MILLTCUFIES OF NUCLEAF: WASTE SHIFFED FFOM SOUTH CAFIOLINA. FOF 1978. EY FACILITY TYFE:

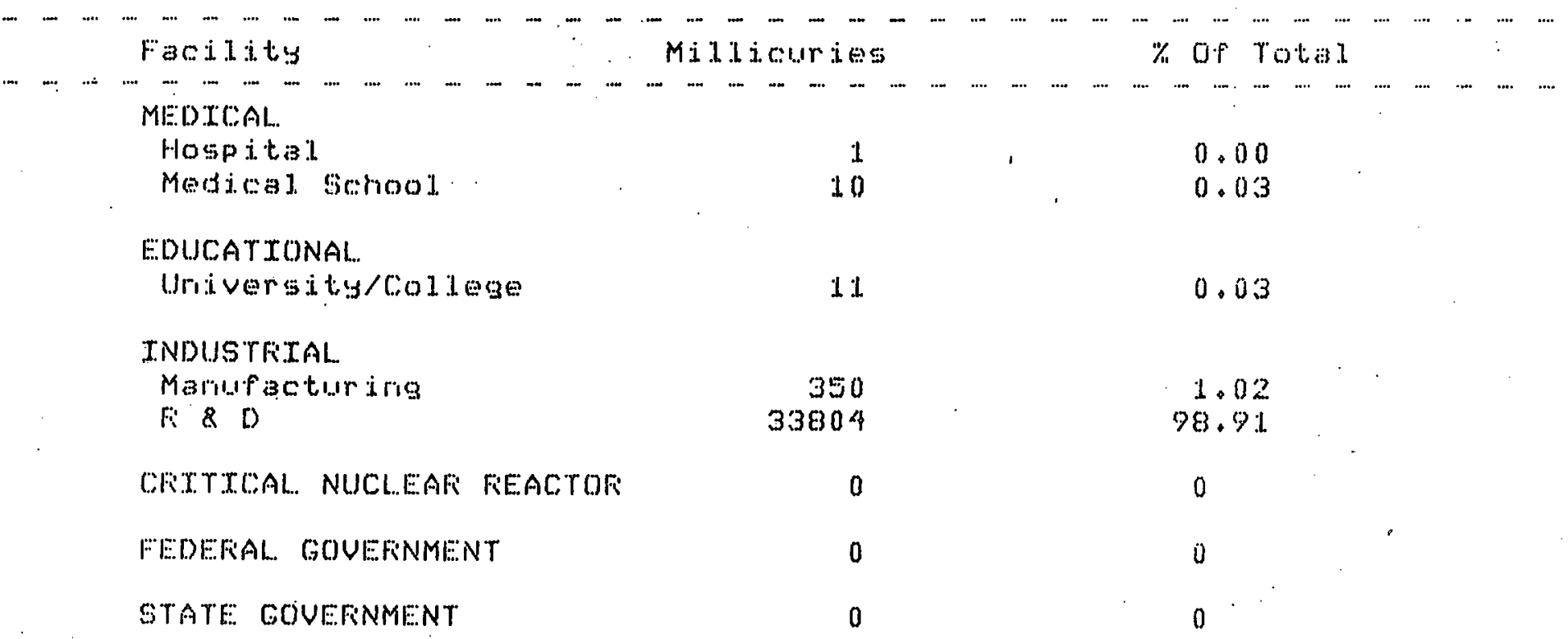


TABLE 6.5 MILLICURIES OF NUCLEAR WASTE SHIFFED FFOM SOUTH CAFOLINA FOF 1979 EY FACILITY TYFE:

Facilitis Militicuries \% of Total

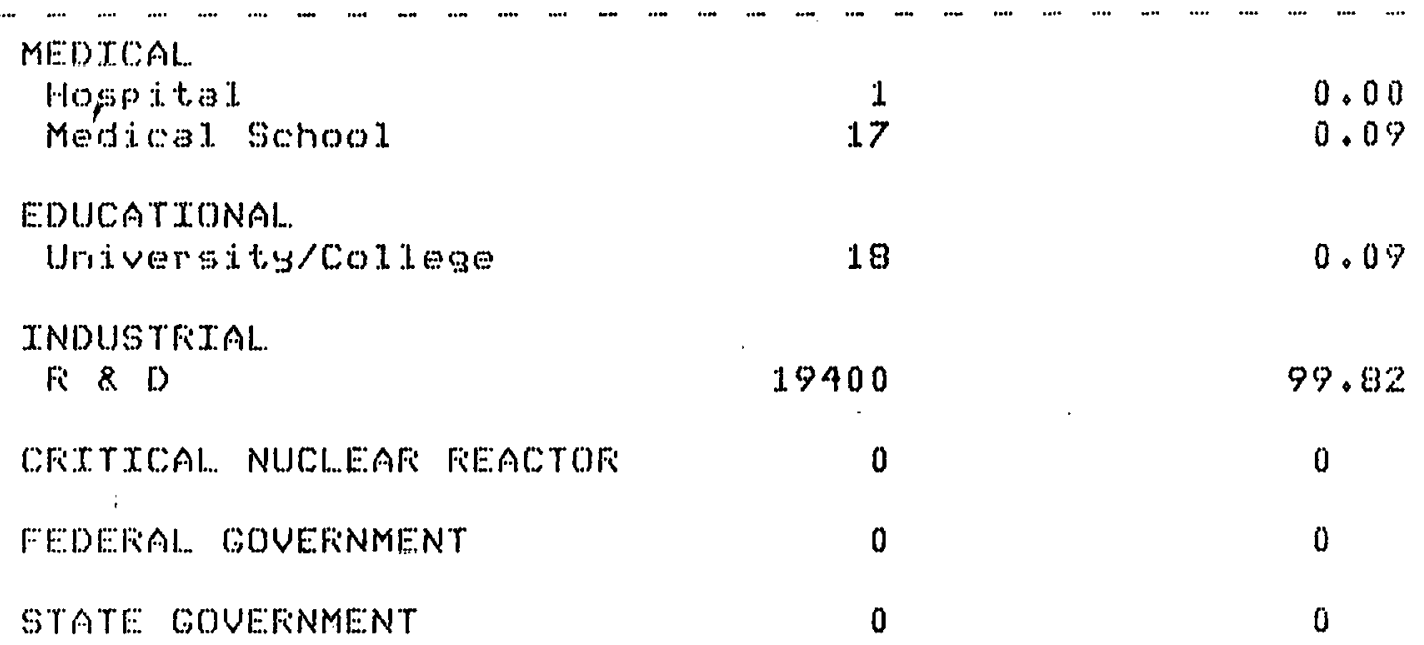


TAELE 6.5 MILLICURIES OF NUCLEAR WASTE SHIFFED FFOM GOUTH OAROLINA FOF 1980 EY FACILITY TYFE

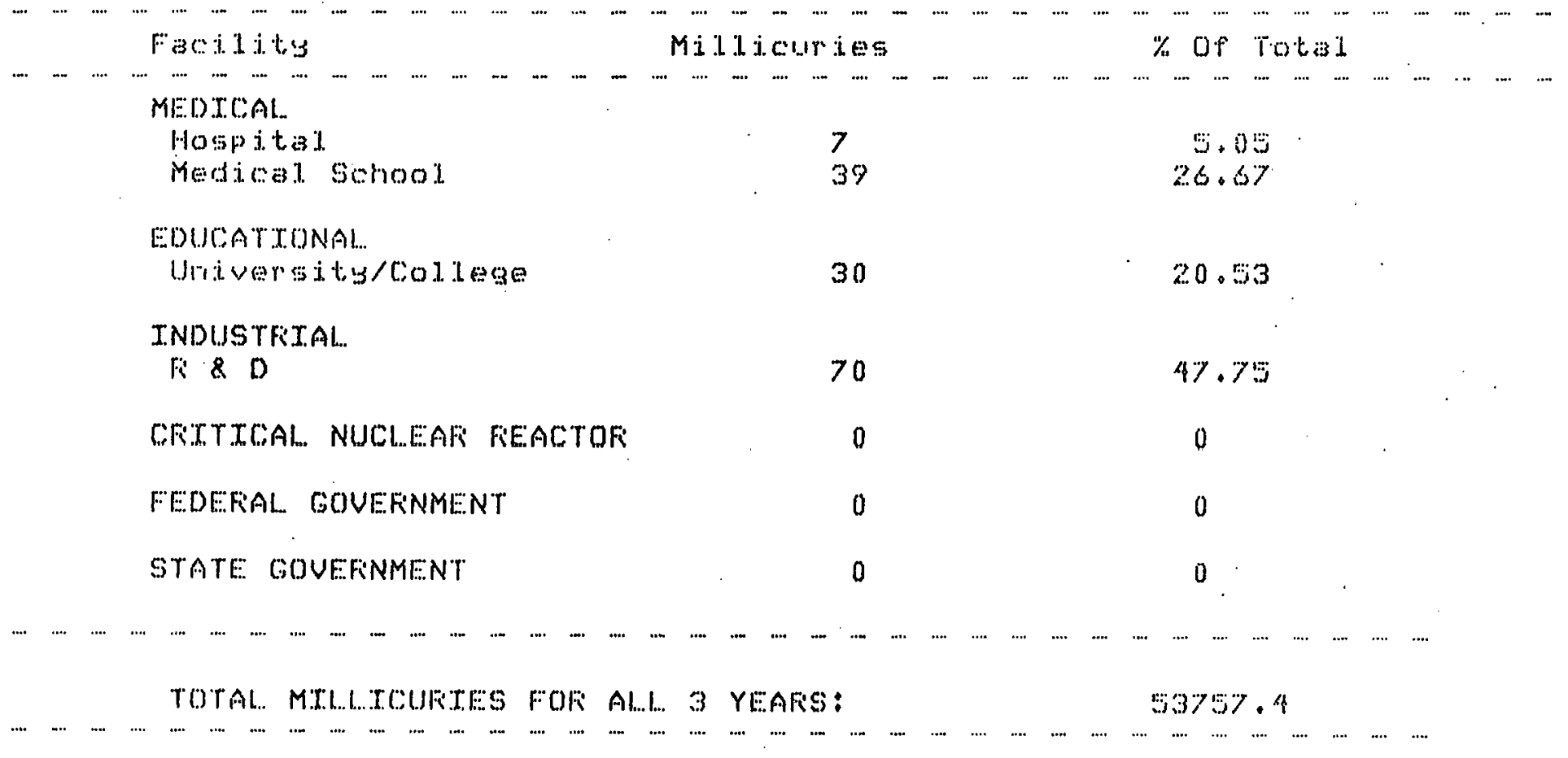


Table 6.6 Cublc Meters of Solid Nuclear Waste Shipped by Facility Type

Table 6.6 represents those respondents to the survey who reported shippling nuclear waste produced from all sources and categorles during one or more years of the study period (1978, 1979, and 1980). The categorles of facilities are the same. The numbers reported in the Total Column represent the number of cublc meters reported shipped. When a specific category was not reported by any licensee, a 0 is shown for that particular category. Each isotope reported on pages 3, 4, and 5 of the survey was included in this table. Isotopes and totals for the three years are shown in millicurles. By using a validation program, multiple reporting of the same lsotope and quantity has been corrected in the totals; $1 . e .$, respondents were found to report duplicated data in both the Medical category and Educational categories. 
TAELE 6.6 CUEIC METEFS OF SOLID NUCLEAF WASTE SHIFFED FFOM SOUTH CAFOL.ZNA FOR 1978 EY FACIILITY TYFE

\begin{tabular}{|c|c|c|}
\hline Medical School & 2.00 & 1.04 \\
\hline $\begin{array}{l}\text { EDUCATTONAL. } \\
\text { Uriversity/college }\end{array}$ & 4.00 & 2.09 \\
\hline $\begin{array}{l}\text { INDUSTFIAL } \\
\text { Mariufatint iris } \\
\text { R \& D }\end{array}$ & $\begin{array}{r}0.45 \\
187.00\end{array}$ & $\begin{array}{r}0.34 \\
97.68\end{array}$ \\
\hline CFITICAL.. NUCLEAF FEEACTOK & 0 & 0 \\
\hline FEDEFAL, GOVEFNMENT & 0 & 0 \\
\hline STATE COVERNMENT & 0 & 0 \\
\hline
\end{tabular}


TAEILE 6.6 CUETC METEFS OF SOLTD NUCLEAR WASTE SWIFFED FFOM SOUTH CAROLINA FOF 1979 EY FACILITY TYFE

Facidit.s

MEDICAAL

Medical School

8.00

3.35

EDUCATTONAL...

Uriversity/Coldege

10.00

$4 \cdot 28$

INDUSTFEAL.

E \&

229.00

95.82

CFITTCALI. NUCLEAR FEACTOF

0

0

FEDERALI.. DOUEFNMENT

0

0

STATE: GOUERNMENT

0

0 
TAELE 6.6 CUETC METEFS OF SOLID NUCLEAF WASTE SHTFED FFOM SOUTH CAFOLINA FOF 1980 EIY FAC.TLITY TYFE

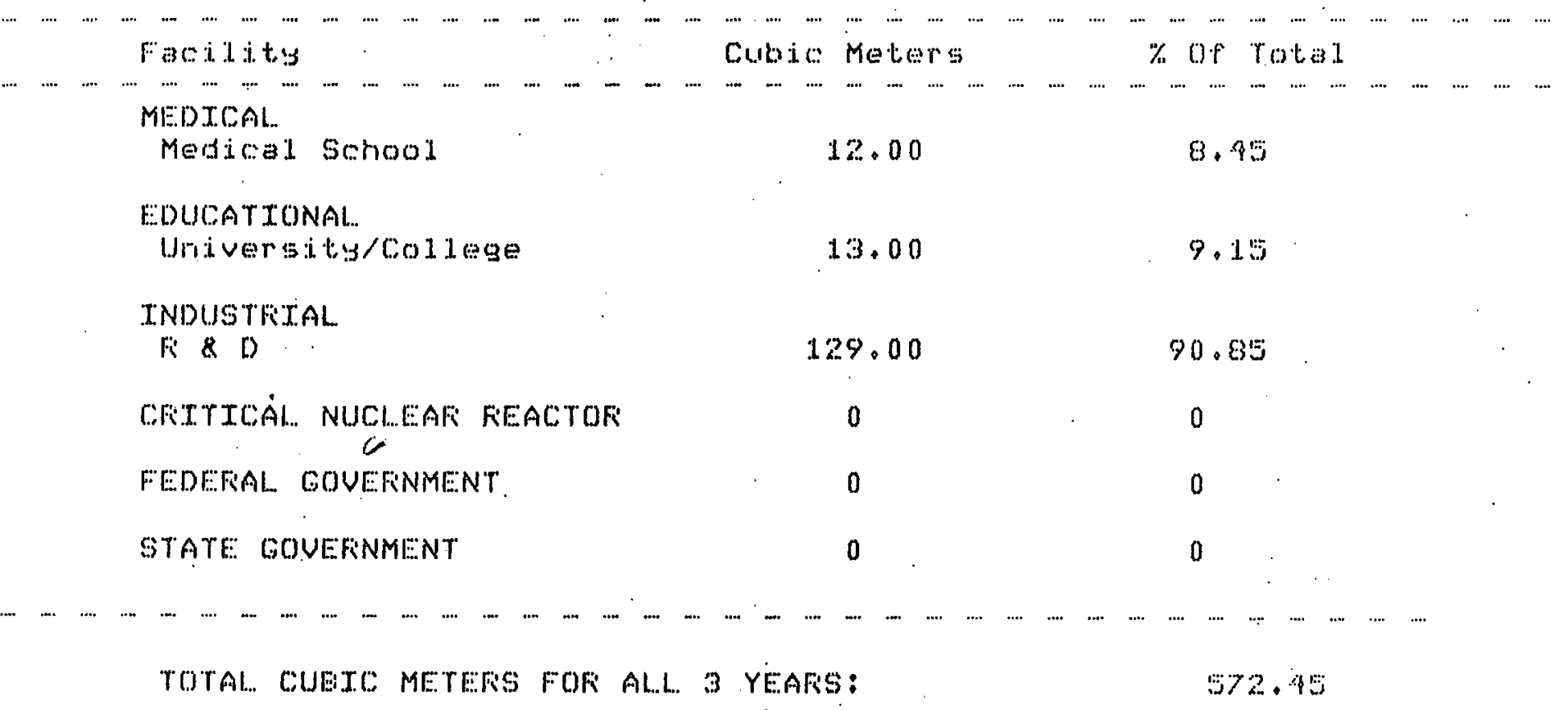


Table 6.7 Liters of Liquid Nuclear Waste Shlpped by Facility Type

Table 6.7 represents those respondents to the survey who reported shippling nuclear waste produced from all sources and categories during one or more years of the study period $(1978,1979$, and 1980). The categorles of facilities are the same. The numbers reported in the Total Column represent the number of 11 ters reported shipped. When a spectflc category was not reported by any licensee, a 0 is shown for that particular category. Each 1sotope reported on pages 3, 4, and 5 of the survey was included in this table. Isotopes and totals for the three years are shown in 1iters. By using a validation program, multiple reporting of the same 1sotope and quantity has been corrected in the totals; 1.e., respondents were found to report duplicated data in both the Medical category and Educational categorles. 
TAEIEE 6.7 LITEFS OF LIRUTD NUCLEAF WASTE SWTWED FFOM SOUTH CAROLINA FOF 1978 EY FACILITY TYFE:

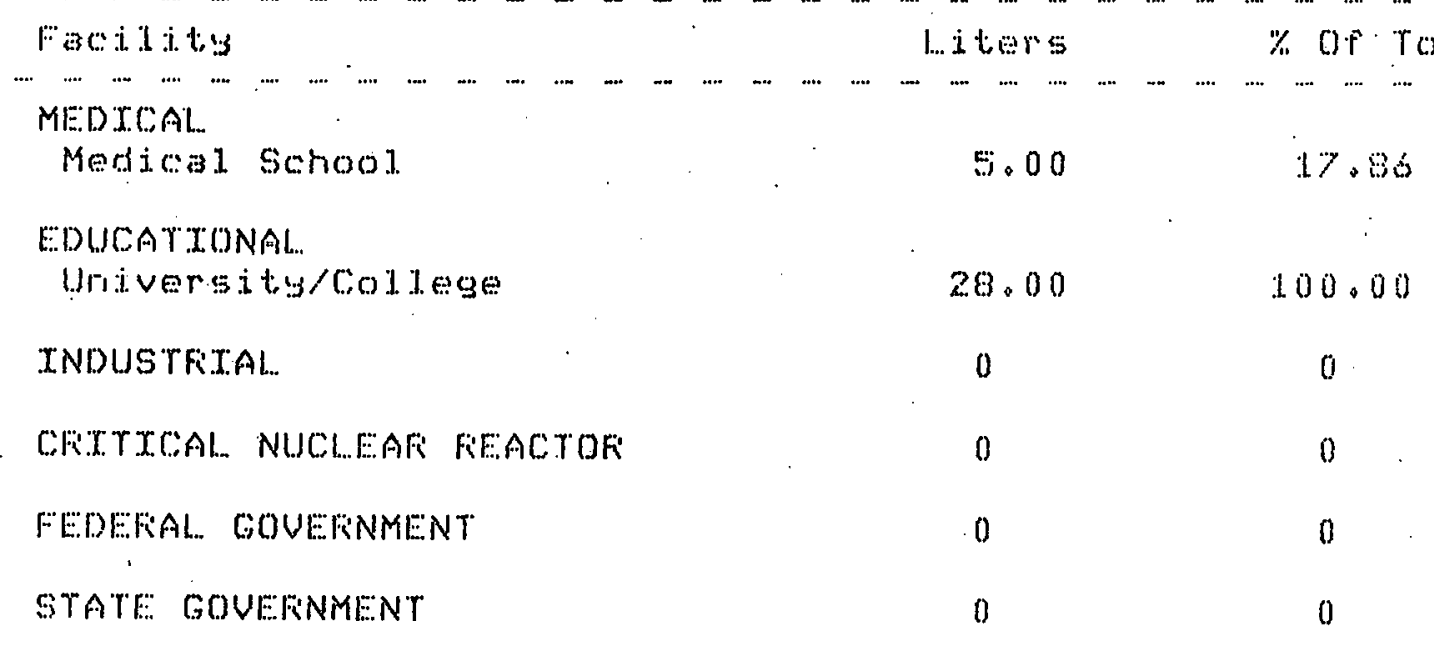


TAELE 6.7 LXTEFS OF LTRUT NUCLEAR WASTE SWIFED FFOM SOUTH CAFOLINA FOF 1.979 BY FACIILITY TYFE:

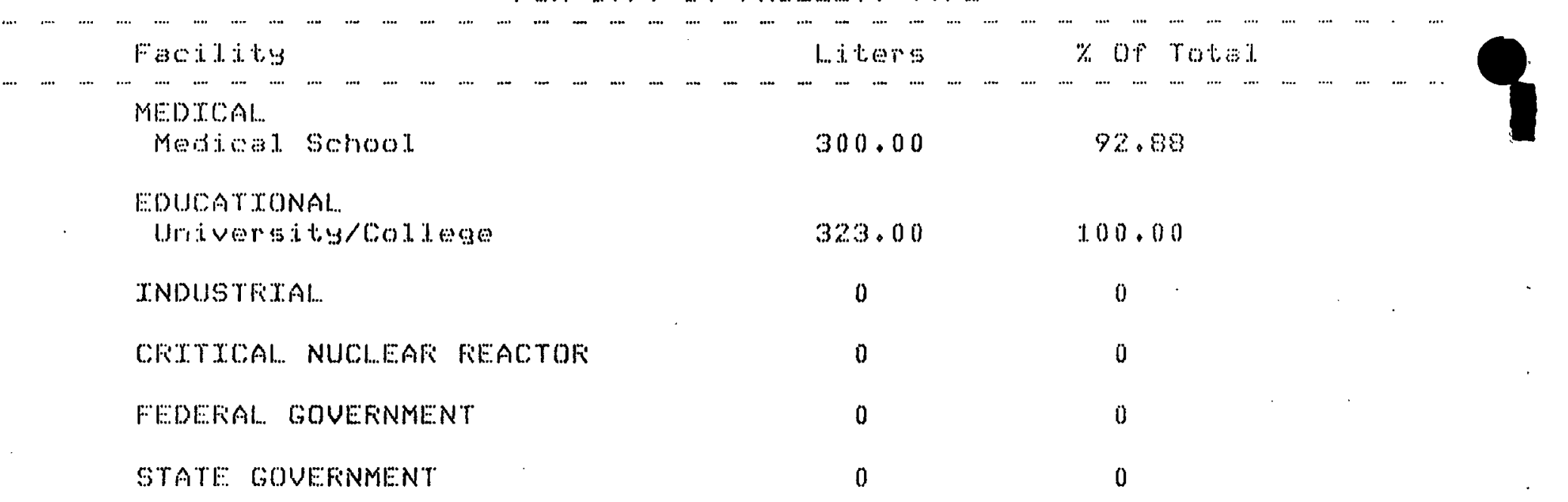


TAEILE G.7 LXTEKS OF LIQUID NUCLEAF WASTE SHIFFED FFOM SOUTH CAFOLINA FOR 1980 EY FACILITY TYFE
Fi: 3 i. i. i. i.:s
1... i. ti, in:
MEDXCAL..
other
Hospitis
1.61
0.14 .4
0.16
0.01
EDUCATTONAL..
Uriversitis/College
High Schood
other
0.14
0.00
0.00
0.0 .1
0.0 .1
2.11
INDUSTEIAL.
Pharmaceltical Mrg.
other
874.00
20.144
91.53
2. + I. L
CFITICAL. NUCLEAR FEACTOF
Noli...Mi I. I. tar.s
STATE COUEFNMENT
other
FEDEFFAL GOUEFINMENT
31.00
$3 \cdot 25$
$2 \dot{8} .00$
2.93

$\%$ or Totail.

TOTAL. LITERS FOK ALL. 3 YEARS:

1.92 .975 
Table 6.8 Percent Responses to the Survey

Table 6.8 represents all licensees responding to the survey. When a respondent reported no waste shipped during the three years of the study pertod (1978., 1979, and 1980), the respondent's survey was divided into one of two major separations in the computer processing. This table 1llustrates the two groups: no waste generated and waste generated.

\begin{tabular}{lccc}
\hline STATE & $\begin{array}{c}\text { NO WASTE } \\
\text { GE NERATED }\end{array}$ & $\begin{array}{c}\text { WASTE } \\
\text { GENERATED }\end{array}$ & $\begin{array}{c}\text { CUMULATIVE } \\
\text { FIGURE }\end{array}$ \\
\hline South Carolina & 65.0 & 35.0 & 96
\end{tabular}


Table 6.9 Nuclear Waste Shipped In Millicurles Isotopes

Table 6.9 represents those respondents to the survey who reported shippling nuclear waste produced from all sources and categorles during one or more years of the study perlod (1978, 1979, and 1980). The categorles of facilities are the same. The numbers reported in the Total Column represent the number of millicurles reported shipped. When a specific category was not reported by any licensee, a 0 is shown for that particular category. Each l'sotope reported on pages 3, 4, and 5 of the suryey was included in this table. Isotopes and totals for the three years are shown in millicuries. By using a validation program, multiple reporting of the same lsotope and quantity has been corrected In the totals; $1 . e .$, respondents were found to report duplicated data 1.1 both the Medical category and Educational categories. 


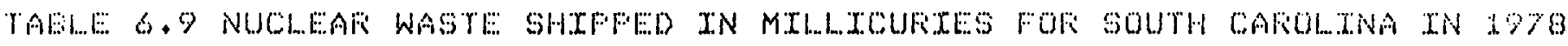

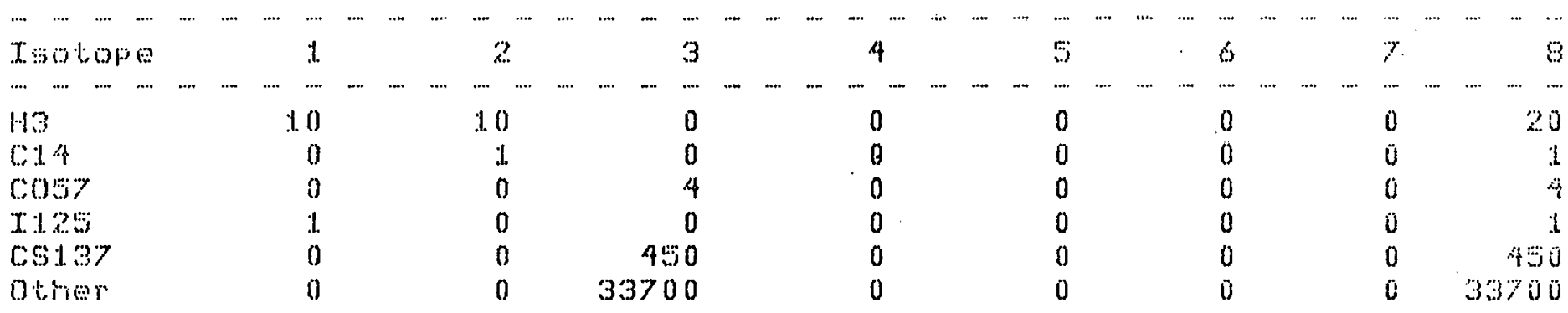

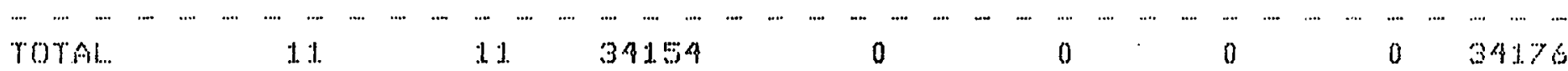

MOTE: SOME RESFONDENTS REFOFTED XN MORE THAN ONE CATEGOFY, THE CUMULATIUE

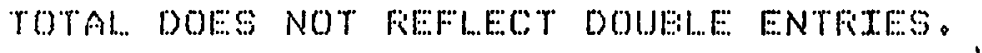

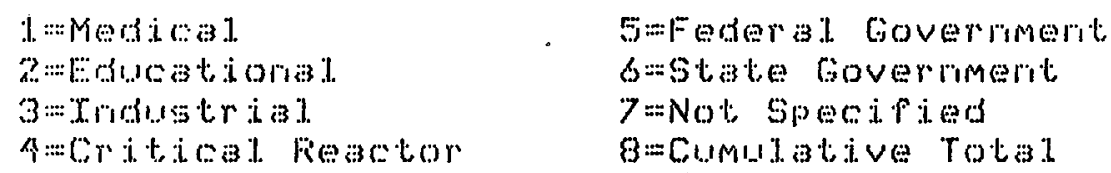


TAELLE 6.9 NUCLEAR WASTE SHIFFED IN MILLICUFIES FOF SOUYH CAROLINA IN 1979

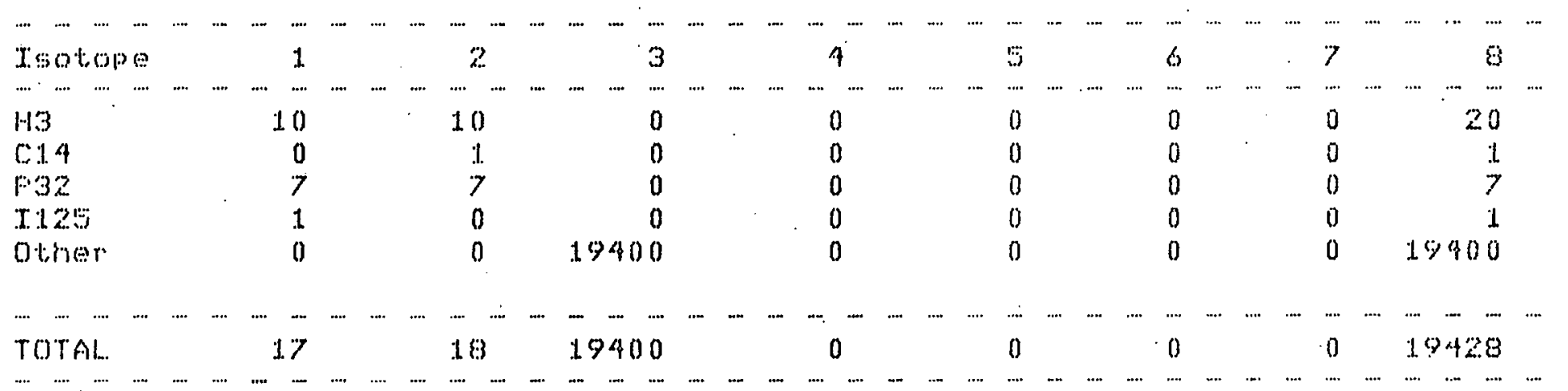

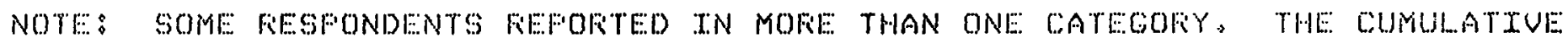
TOTAL DOFS NOT FEFLEECT DOUELEE ENTFIES.
1 : Medicas
2: Explucational.
5in finer a covernment

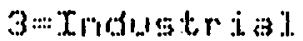
$b=S t a t e$ Coverliment
A Cortition Feactor
$7=$ Not Spenditid
$8=C$ Cumind


TAELE G.9 NUCLEAR WASTE SHIFFED IN MILLICURTES FOR SOUTH CABOLINA IN 1980

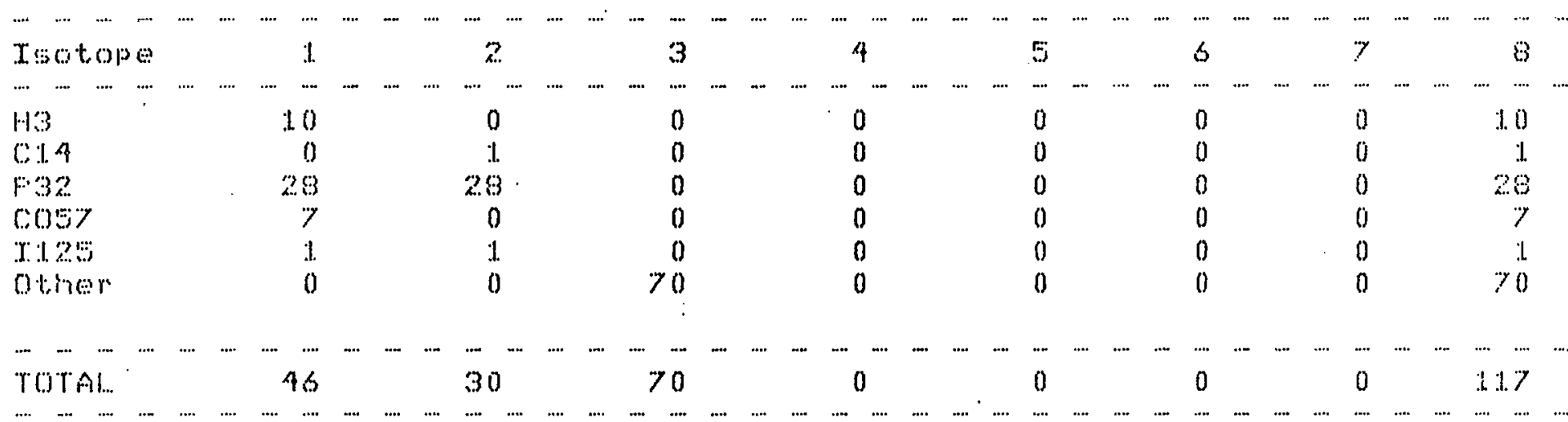

NOTE: SOME: FESFONDENTS FEFOFTED IN MOFE THAN ONE CATEGOFY THE CUMULATIVE TOTAL. DOES NOT FEFLECT DOUELLE ENTFIES.

\begin{tabular}{|c|c|}
\hline 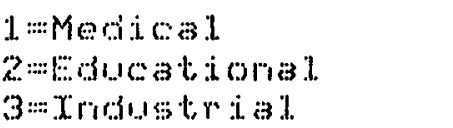 & $\begin{array}{l}5=F e d e r a t \text { Government } \\
6=5 t a t e \text { Government } \\
7=\text { Not snocified }\end{array}$ \\
\hline A cor it tical Reacotor & $8=C$ Commitititive Totis $t$ \\
\hline
\end{tabular}


Table 6.10 Nuclear Waste Shipped Classified by Hazard

Table 6.10 represents those Ilcensees reporting the use of nuclear materials in all forms who reported shipping hazardous forms of nuclear waste dur1ng one or more years of the study period (1978, 1979, and 1980). The categories of facilities are the same. The numbers reported in the Total Column represent the number of licensees reporting shipping nuclear waste. Percentages were computed for each category to equal 100 percent. When a specific category was not reported by any 11censee, a 0 is shown for that particular category. The number of times a shipment took place is represented in this table. Each hazardous classification reported in Sections 10, 16, and 22 of the survey are reported in this table... Po- tentlally hazardous materlals such as corrosive, toxic, flammable, volat1le, and explosive materials are reported. 


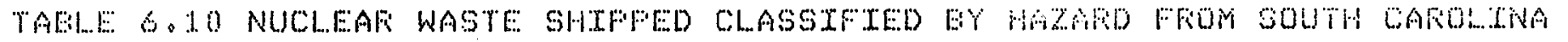
Fis i. i. it. HAZARD CLASS

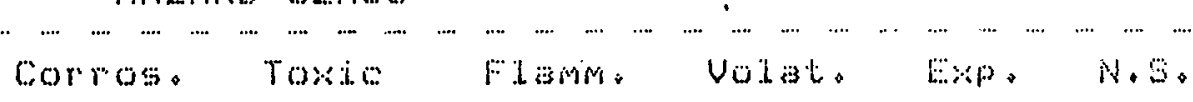

MEDXCAL...

Hosp it to: 1

Otimen

0

0

$0 \quad 0$

$0 \quad 0 \quad 000$

EDUOATrONAL...

other

0

0

0

()

0.3

XNDISTRTAL.

otimer

0

0

0

$0 \quad 0 \quad 3$

ORTYTCAL. NUCIEAF REACTOK

0

0

0

0

0

0

FFEFEAL OOUEFNMENT

Nom.... i. i. i. tary

U

STATE GOULFNMENT

0

0

0

$0 \quad 0$

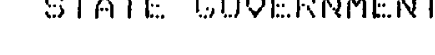

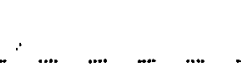

TOTALLS

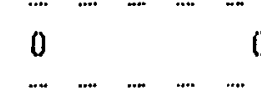

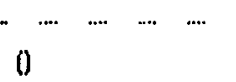

() 0000

Corros + corrosive

Toxil on Toxio

Volat a volatide

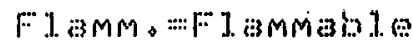

Exp , . : Exp I Cisive

N.S. =Not Spedried

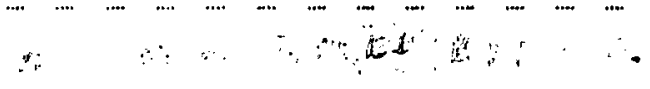


Table 6.11 Nuclear Waste Sh1pped Classified by Container Type

Table 6.11 represents those licensees using nuclear materials who reported the types of shlpping contalners used for transporting nuclear waste during one or more years of the study perfod (1978, 1979, and 1980). The categorles of facilities are the same. The numbers reported In the Total Column represent the number of licensees reporting shipplng nuclear waste. Percentages were computed for each category to equal 100 percent. When a specific category was not reported by any 1 icensee, a 0 is shown for that particular category. The number of times a shipment took place 18 represented in this table. Each contalner type classification reported in Sections 10, 16, and 22 of the survey are reported in this table. Shipplng contalner types Include Kraft containers, 55 gallon drums, 30 gallon drums within 55 gallon drums, and types not specified. 


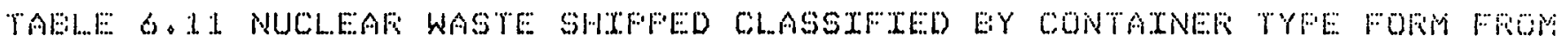
GOUTH CIAROLIXNA

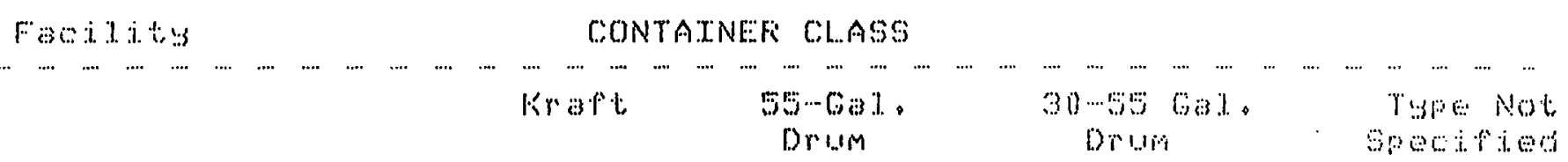

FEUCATXONAI...

otiner

TNDUSTRxil..

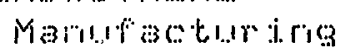

Fis $\quad$ D

other

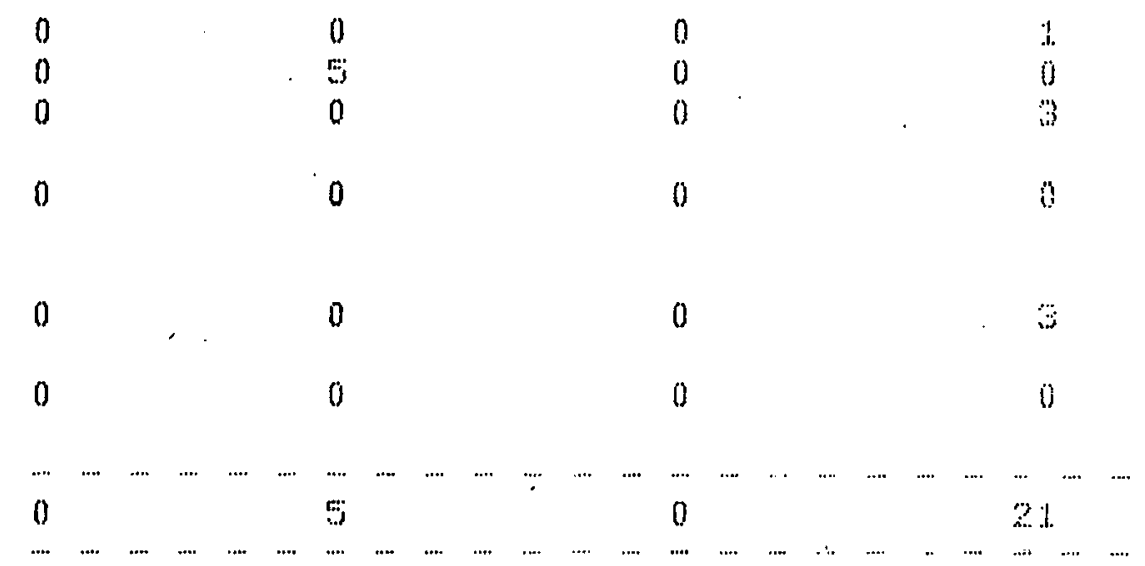

curros. morrosive

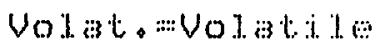

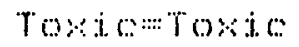

Exp。: Exp ] osi. ive

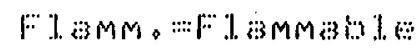

N.S. NNot Spedrited 
Table 6.12 Nuclear Waste Shipped Classifled by Physical Form

Table 6.12 represents those licensees reporting the use of nuclear materials who reported the specific forms of the waste which was shipped durfing one or more years of the study period (1978, 1979 and 1980). The categortes of facilities are the same. The numbers reported in the Total Column represent the number of licensees reporting shipping nuclear wiastê. Pèrêntages were computed for each category to equal 100 percent. When a specific category was not reported by any licensee, a zero is shỡ fôn that particular category. The number of times a shipment

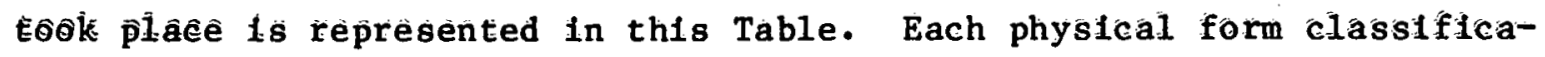

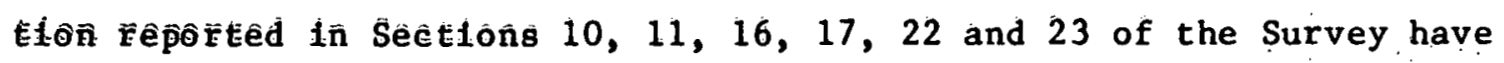
Beên Eâbiliated ln this Table. The waste forms reported were dry solids,

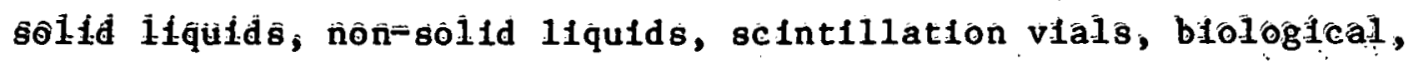
gàtệ̀is and seâled sources. 


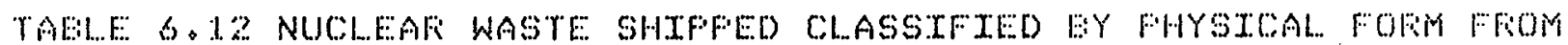
SOUTH CAAROLINA

F...... i. i. i. li:3

FHYSICAL CILASS

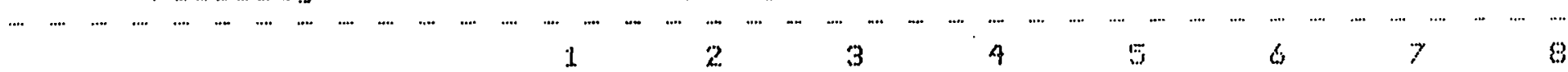

MIEIC:

Hosis itis

Cil. initio:

$\begin{array}{llllllll}0 & 5 & 0 & 0 & 0 & 0 & 3 & 0 \\ 0 & 0 & 0 & 0 & 0 & 0 & 3 & 0\end{array}$

EDUC:ATTONAL..

$\begin{array}{lllllllll}\text { Universitiscolitege } & 0 & 0 & 3 & 0 & 0 & 0 & 0 & 0 \\ \text { otiner } & 0 & 0 & 0 & 0 & 0 & 0 & 3 & 0\end{array}$

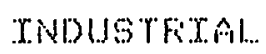

Marionetion ino

B \& D

other

$\begin{array}{llllllll}0 & 0 & 0 & 0 & 0 & 0 & 1 & 3 \\ 3 & 0 & 0 & 0 & 0 & 0 & 0 & 2 \\ 0 & 0 & 0 & 0 & 0 & 0 & 3 & 0\end{array}$

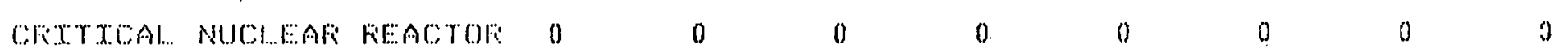

FEDEFAL GOUEFNMENT

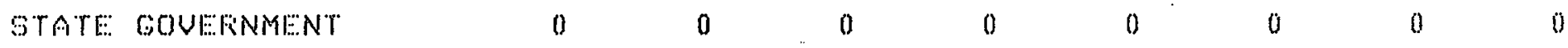

$\begin{array}{lllllllll}\operatorname{rotans} & 3 & 5 & 3 & 0 & 0 & 0 & 13 & 2\end{array}$

1.

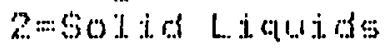

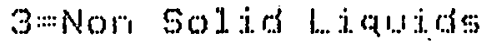

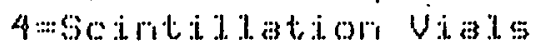

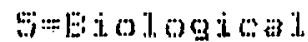

$6=6$ का

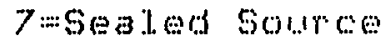

8=Type Not specified 
Table 6.13 Nuclear Waste Shipped Classifled by Reduction Process Used

Table 6.13 represents those 11 censees using nuclear materials who reported the reduction process of the waste shipped during one or more years of the study period (1978, 1979, and 1980). The categorles of facilitles are the same. The numbers reported in the Total column represent the total number of licensees reporting shipping nuclear waste. Percentages were computed for each category to equal 100 percent. When a specific category was not reported by any licensee, a 0 is shown for that particular category. The number of times a shipment took place is represented in this table. Each reduction process classification reported in Sections 9, 15, and 21 of the survey have been tabulated in this table. The reduction processes reported were compaction; solidification, evaporation, absorption and incineration. 


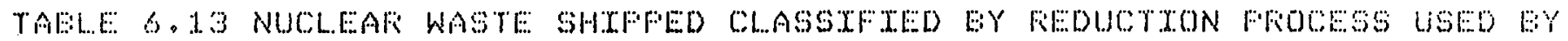
SOUTH CIAROLINA

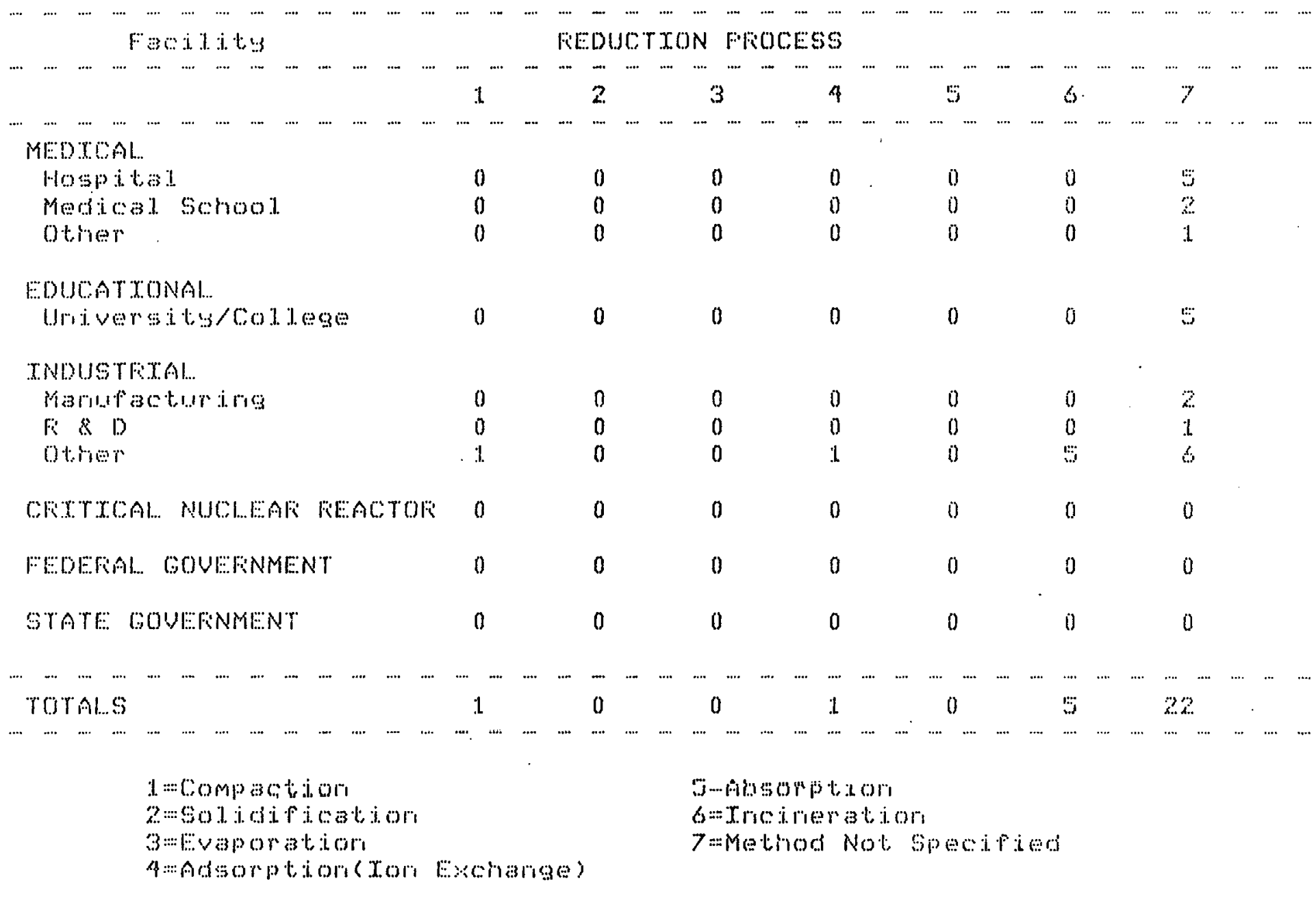


APPENDIX A: Annotated Bibliography 
"Antinuclear Pressure Growing in South Carolina; Barnwell Volume to be Cut," Nucleonics Week, November 1, 1979.

Governor Riley has been warning the other states for over a year about the need to develop other low-level nuclear waste repositories...the site is currently accepting over 2.4 million cubic $\mathrm{ft} / \mathrm{yr}$ of low-level waste and its life is now at most 15 years.

Barnwe11; It's Your Back Yard. Southeastern Natural Guard, Barnwe11, SC. The Print Shop, Athens, GA. January 1980.

"This magazine offers information about the nuclear faci1ities in Barnwel1: the effect and dangers of nuclear waste, serious unsolved problems, the political and economic realities we must face, and our options for the future." A collection of statements prepared for a coalition of safe energy groups in the Southeast who planned the Barnwell II Action.

Brief History of State Licensing Activities: Chem-Nuclear Systems, Inc. Barnwell, SC. Chem-Nuclear Systems, Inc. n.d.

Follows development from August 1969 when first application was received noting 26 amendmento to license with 7 complete revisions. Information includes land utilization map/stateby-state'monthly disposal amounts for $7 / 79$ to $11 / 80$. The economics of establishing a low-level facility in 1985 is presented in tabular format. Significant financial activity that Chem-Nuclear has had in the State of South Carolina is alco presented for years 1976-1979.

The Chem-Nuclear Systems Low-Level Waste Disposal Site. Chem-Nuclear Systems, Inc. n.d.

Includes listing of monthly waste volumes for states (Sept. 79 thru Nov. 1980); DOE 1980 estimated low-leve1 waste; economics of establishing a low-level waste disposal facility in 1985; and significant financial activity for Chem-Nuclear in the State of South Carolina. 
A Classification System for Radioactive Waste Disposal - What Waste Goes Where? Ford, Bacon \& Davis Utah; U.S. Nuclear Regulatory

Commission. Division of Fuel Cycle \& Material Safety. July 1978. (NUREG-0456; FBDU-224-10).

Survey of existing low-level waste disposal facilities (p. 19, Table 4) includes Savannah River and Barnwell, SC. Data covers commercial capacity, climate, nearby rivers, cover depth and observed radionuclide migration. Chapter 6: long-term storage/disposal site selection includes Barnwe11, SC. Chapter 7: remedial action alternatives addresses decontamination and and the material removed to Barnwell, SC.

"Compromise Efforts Fails: Congress Passes Low-Level Nuclear Waste Bills, Leaves Broader Solution for Future," Congressional

Quarterly Weekly Report, December 20, 1980.

When the nuclear waste bill appeared dead Dec 10, (Governor) Riley's office let it be known that the Governor was considering closing South Carolina's Barnwell dump to all outof-state wastes if Congress did not pass a bill that at least dealt with low-level waste.

"Disposal of Low-Level Radioactive Wastes. Issue Brief." Science and Technology for the Leg1slature. Vol.5, No. 4, Fall 1979.

The "rutback in the amount of $L L W$ to be accepted at the Chen-Nuclear Systems site in Barnwell, SC has caused a problem for generators of LLW...the Barnwell site had refused to accept scintillation vials or absorbed liquid wastes...Chem-Nuclear site must reduce the amounts of waste stored...Barnwell (at its present rate...) will reach its acceptance limit in 1979; NRC....can request DOE to accept commercial LLW....affected site includes Savannah River Plant.

Draft Environmental Statement Related to Operation of Virgil C. Summer Nuclear Station Unit No. 1. South Carolina Electric and Gas.

Docket No. 50-395. U.S. Nuclear Regulatory Commission. Office of Nuclear Reactor Regulation. June 1979. (NUREG-0534).

Table 3.4 details estimated annual quantities of solid radioactive wastes from the Summer station. Table 4.20 details summary of environmental considerations for uranium fuel cycle including shallow land burial of low-level wastes. "The Commission notes in Table 4.20 that there will be no significant radioactive releases to the environment." 
Draft Environmental Statement Related to the Operation of the Barnwell Fuel Receiving and Storage Station. Docket No. 70-1729. U.S. Nuclear Regulatory Commission. Division of Materials and Fuel Cycle Facility Licensing. May 1975. (NUREG 75/026). During the operation of BFRSS, radioactive materials will be received... from these materials, small amounts of radicactive waste will enter the liquid waste streams... and solid wastes that will leave the plant. These wastes will be monitored...Waste handling and treatment systems....are di $\varepsilon$ cussed in the applicant's License Application (p.3-8).

"Efforts of States on Waste Disposal Problems Have Yet to Bear Fruit," Nucleonics Week, August 21, 1980.

The NGA report of $8 / 3$ concludes that "the 3 States ( $S C$, NV and WA) now with facilities for waste disposal are not going to accept the burden any longer..." The NGA taik force found its origins with last years low-level waste repository shut-down at Barnwell, Beatty and Hanford.

Evaluation of Alternative Methods for the Disposal of Low-Level Radioactive Wastes. Ford, Bacon \& Davis Utah, Inc.; U.S. Nuclear Regulatory Commission. Low-Level Waste Branch. July 1979. (NUREC/ CR-0680; FBDU-209-03).

Table B.1 details capacities and waste quantities handled at existing sites including Savannah River and Barnwell, Srj. Statistics include burial trench slze; type and depth of cover; fill procedure; covering frequency; provisions for water collection and contalnment; volume burled and cumulative date. Table B.2 shows climatological and hydrogeological parameters at those sites. Table B-2 gives commercial low-level waste burial history for by-product material buried for years 1971-1976, and for low-level waste characterization of special nuclear materials and source materials.

An Evaluation of Low-Level Radioactive Waste Burial Ground Capacities at the Major DOE Reservations. Technology for Energy Corporation; Cak Ridge National Laboratory. National Low-Level Radioactive' Waste Program. January 29, 1979. (ORNL/NFW-79/17).

Section 7. Savannah River Plant Includes Table'15 (p.32): volume of solid low-level, radwaste burled or non-retrievab1y stored from FY 1973 through FY 1977 and forecasted volume from FY 1978 through FY 1985 and the corresponding burial grounds requirements at SRP. Table 16 (p.35): authorized land for burial of solid low-level non-TRU radwastes at SRP. 
An Evaluation of Nuclear Emergency Preparedness in South Carolina.

The State of South Carolina General Assembly Legislative Audit Council. Columbia, SC (1980?)

Review revealed a number of deficiencies in the overall state of emergency preparedness.

Fact Sheet on Low-Level Radioactive Biomedical Waste: National Academy of Sciences. Office of Information. November 13, 1980.

"Most of the wastes is generated in the larger research facilities in the eastern United States...disposal sites include Barnwell, SC; the site in SC will accept...a reduction of 2.4 to 1.2 million cubic $\mathrm{ft} / \mathrm{yr}$.

"Feeling the Pinch (Low-Leve1)," Nuclear News, December 1979.

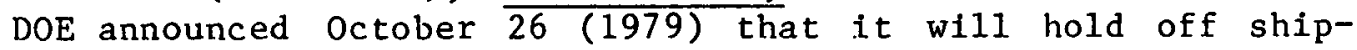
ping low-level wastes to commercial disposal sites, including the Chem-Nuclear System facility at Barnwell. The 18 DOE or DOE contractor operations that generate low-level waste will now direct their shipments to 5 DOE preserves for temporary storage...including the Savannah River Plant in SC. By order of the SC Governor, the Chem-Nuclear site will take in $1 / 2$ as much annually as it now does by October 1981 .

Final Task Force Report on the Agreement States Program. Regulatory Commission. Office of State Programs. Desamber 1977. (NUKE'(S-U388).

Appendix A, Attachment B lists agreement states with dates of agreements as signed and effective and number of licensees as of $12 / 31 / 76$.

Identification and Assessment of the Social Impacts of Transportation of Radioactive Materials in Urban Environments. Battelle Human Affairs Research Centers; U.S. Nuclear Regulatory Commission.

Division of Engineering Standards. July 1980. (NIJREG/CR-07/1;

SAND 79-7032; B-HAR̄G-411-049).

Table 3 listing state statutes governing the transportation of radioactive materlals shows that the SC Code Sec. 13-7-70 governs general activities; keeping with access to records and manifests; lnaring, packing, labeling and marking; as well as monitoring, survelliance and inspection. 5465 considers advance notification on proposed route and registration fees, permits and licensing for communities. 
Identification of Socioeconomic and Institutional Barriers to Radioactive Materials Transportation. Project One. Southern States Energy Board Radioactive laterials Transportation Study. Draft Two. Atlanta, GA. October 6, 1980 .

Overview of the low-level disposal facility at Barnwell, SC covers its location; burial capacity; burial statistics; limitations on burials; financial assurances; agreement states; state statutory authority; state regulation; public sector involvement; license and initiatives instituted at the state level in behalf of the executive and legislative departments of the government as well as those instituted on behalf of the operator. From 1973-1978 the files of the Transportation Technology Institute at Sandia National Laboratories list 130 radioactive material transportation incidents/accidents in SC. Relevant statutes and regulations for the State of SC are included.

Identification of Technical Problems Encountered in the Shallow Land Burial of Low-Level Radioactive Wastes. Evaluation Research Corpor-ation; Oak Ridge National Laboratory. March 1980. (ORNL/ SUB-80/13619/1).

The operating histories of burial sites at 6 major DOE and 5 commercial facilities in the US are examined, including Barnwell, SC. P.16 "hydrogeologic data avallable at most sites is insufficient to permit the design of an adequate monitoring system." Appendix (p. 56-61) gives site

characteristics as to location, climate, geology, hydrology and ecology; licensing date and conditions; dates of operation; operation techniques and usage; monitoring and problems for Barnwe11, SC. Similar information for Savannah River Plant 0 . pages $136-145$.

Institutional Radioactive Wastes. University of Maryland, Radiation

Safety Office; U.S. Nuclear Regulatory Commission. Division of Safeguards, Fuel Cycle and Environmental Research. 'March 1978. (NUREG/CR-0028).

"It is notable that the largest fraction of the institutional waste volume (30\%) is shipped to the Barnwell, SC site" (p.37), for institutions surveyed in 1975. 
Interim Report. State Planning Council on Radioactive Waste Management. February 24, 1981.

Section IV: Low-level radioactive waste discusses the strict enforcement of shipping and packaging standards and the reduction of waste accepted at the South Carolina site.

"Inventory (1962-1978) and Projections (to 2000) of Shallow Land Burial of Radioactive Wastes at Commercial Sites: An Update," Nuclear Safety v.21, no.3, May-June 1980.

The U.S. Environmental Protection Agency has worked with the 6 states having commercial shallow land burial facilities for other-than-high-level radioactive wastes to provide inventories and quantities of wastes huried at these sites. Compilations and interpretations of the inventories are herein presented in tables and figures. Table 2 shows waste volumes, $M^{3}$ for SC site from 1977-1978; Table 3 details byproduct materials in $\mathrm{Ci}$; Table 4 lists special nuclear materlals in $\mathrm{g} \cdot$; Table 5 includes source material in $\mathrm{kg}$; Table 8 gives 1979 projected average annual volume of lowlevel waste generation, $10^{6} \mathrm{M}^{3} / \mathrm{y}$ for 1979-1980; $1981-1990$ and 1991-2000. "The projected cumulative volume of waste generated indicates that the burial capacity may be inadequate by the mid-1980's."

Letter from H.R. Oakley (Chem-Nuclear System) to K. Nemeth (SSEB). January 21, 1981.

Attachments show volume of waste received and buried at Barnwell for 9 Southern States, 1978-198n; generating ouotomero in the State of Georgia; institutional wastes for the 9 states; and total institutional wastes received and buried at Barnwell. from $1 / 75$ to $9 / 79$.

Low-Level Radioactive Waste Management. Proceedings of Health Physics Society. 12th Midyear Topical Symposium. February 11-15, 1979. Williamsburg, VA. U,S. Environmental Protection Agency. Office of Radiation Prozrams. May 1979. (EPA 520/3-79-002).

In 1977 national survey of radwaste volumes generated by large medical and academic institutions; $78 \%$ of the waste noted by respondents was shipped to the shallow land burial site at Barnwe11, SC. Discussion of charges for burial at Barnwel1. The operational experience at Chem-Nuclear's Barnwell Facility (p.133-140). History of shallow land burial, Table 1 ( $p .230$ ) shows volume of wastes and amount of activity burled at low-level sites cumulative thru 1977. 
Low-Level Radioactive Waste Management Report. Response to Public Law 96-573, the Low-Level Radioactive Waste Policy Act. U.S. Department of Energy. March 13, 1981.

Table 1 , shows distribution of waste at burial site and includes Barnwell for low-level waste disposed of iu commercial burial grounds by each state in 1979. Section B.2 detalls status of Barnwell, SC site as to locale, climatology, licensing, monitoring, fee structure and current allocation plan. "The State of South Carolina has closely monitored operation at Barnwell site and the site is well run" (p.27). Table 4 lists DOE low-level waste disposal sites, including the Savannah River Plant at

Aiken, SC."...(DOE) sites would not be sufficient to handle the large increase in waste volumes which would result should commercial sites be closed..." Table A-2 lists commerciai low-level rad waste, 1979 base year data for all states. Table A-3 lists low-level waste from present and projected reactor operations for all states. Table A-4 shows commercial low-level radioactive waste projection sumary: by $\mathrm{re}^{-}$ gion (1979-84). Figure A-1 outlines regional commercial waste volume projections, Region 1, Southeast.

"Low-Level Radioact1ve Waste Strategy Document," Radioactive Waste Techology Newsletter. August 1980. (ESIC-ORNL).

When the commercial disposal sites...leaving only the site at Barnwell, SC...projections indicate that sometime in the mid-1980s generators will produce more waste than the operating disposal sites will be able to accommodate.

Low-Level Waste Management Summary - Issue Brief. National Conference of State Legislators. Office of Science and Natural Resources. August 1,1980 . (EV/WR/LO).

Brief includes discussion of background of waste site; legislative issues; cases; policy actions (both state and federal); review of DOE interagency review group; establishment of. State Planning Council; glossary of low-level related terminology and bibliography of references. Commercial burial sites include Barnwell, SC. Governor(s) of SC have volced concern about potential dangerous operating conditions at the operating site in their state. Table 2 shows waste volume distributed by State (1978) and includes percentage of total U.S. volume. Governor of SC stated that (his) State should not be asked to continue to act as sole repository for the country's waste. 
Meeting on Low-Level Radioactive Waste, Proceedings; held at Incline Village, Nevada, February 20-21, 1980. U.S. Nuclear Regulatory Commission. Office of State Programs. July 1980. (NUREG/CP0013).

Concerns about waste volume reductions and high integrity containers, especially in the case of regulation by the State of South Carolina are expressed by J.N. McLeod (Southern Company Services); H. Oakley (Chem-Nuclear System, Inc.) addresses the inspection program as related to the Barnwell site on incoming shipments including discrepancies in those shipments for $6 / 20 / 79$ to $1 / 31 / 80$. Heyward Shealy (State of South Carolina) discusses the licensing for the Chem-Nuclear operation.

NRC Task Force Report on Review of the Federal/State Program for Regula-

tion of Commercial Low-Level Radioactive Waste Burial Grounds.

U.S. Nuclear Regulatory Commission. Office of Nuclear Material Safety and Safeguards. March 1977. (NUREG-0217).

Appendix B - history of low-level waste management (Table B-1) covers location, operator, year of original license; whether or not TRU is accepted and operational rates for 6 sites Including Barnwell, SC. Pages 55-57 outline summary of meeting with South Carolina attendees. Discussion included information drawn from South Carolina's experience.

Need for Greater Regulatory Oversight of Commercial Low-Level Radioactive Wastes. Report by the U.S. General Accounting office. August 16, 1978. (EMD-78-101).

Currently (78) there are 6 low-level waste burial grounds... Barnwel1, South Carolina...however 3 of the 4 burial sites in the eastern United States, are no longer accepting waste for burial. As a result, the Barnwell, SC facility is the only eastern burial site. For political and economic

reasons, SC recently imposed a monthly limit on the amount of waste buried at Barnwell. Because of this restriction, NRC has requested DOE for use of their burial facilities as backups. 
Nuclear Energy Center Conceptual Study. Phase III: Site Specific

Evaluation. Topical Report - Storage of Low-Level Radioactive

Wastes. Gilbert/Commonwealth, Inc.; Southern States Energy

Board. January 1981. (DOE/OR/06074-1. Vol. IX).

The prevalent method of $L L W$ disposal is continuous offsite disposal at an existing facility such as the one at Barnwell, SC. The conceptual design of an onsite LLW disposal facility herein described is an improvement on the technology present15 in use at Barnwell, SC; and it began with a review of the Lake Hartwell NEC site to locate the areas within the boundary suitable for a disposal facility for the shallow land burial type. "Increasingly stringent regulations on transportation and storage of radioactive waste and limited capacity of the currently licensed disposal facilitles at Barnwell, SC, etc. has made it apparent that onsite storage of radioactive wastes may become necessary..."

"Nuclear Waste: Concern Growing over Problem, But Congress Can't Agrae on Bill," Congressional Quarterly Weekly Report. November 1, 1980. Storage sites for commercial nuclear waste - existing ar.i potential noted on Map of U.S. (p.3261).

Nuclear Waste Management Program. Summary Document. FY 1981. U.S.

Department of Energy. Office of Nuclear Waste Management.

March 1980. (DOE/NE-0008).

Section 2.4 - Savannah River Plant...significant amounts of LLW are rountinely generated...LLW management is accomplished through shallow land burial at the onsite burial grounds...Approximately 320,000 cubic meters of solid waste burled on-site.

The Problem of Disposing of Nuclear Low-Level Waste: Where Do We Go From Here? U.S. General Accounting Office. Report to the Congress of the United States by the Comptroller General. March 31, 1980. (EMD-80-68).

As late as 1975, six commercial low-level waste burial 'sites were licensed to operate...only 3 remaln operational...cne in SC. On October 31, 1979, the Governor of SC ordered Barnwell to scale down...so that by October 1981 it would bury $1 / 2$ as much annually... The Governor(s)...have stated that packaging and shipping problems must be corrected...they feel it is not appropriate... for three state(s) to shoulder the burden ...urged other states to develop regional sites...unless the imbalance in low-level waste disposal is relieved, the state(s) may unilaterally decide to close their sites... 
Radiological Emergency Response Planning Operations, Radiological

Environmental Monitoring Programs and Highway Transportation of Radioactive Materials in South Carolina. Committee Report. South Carolina Joint Legislative Committee on Energy. Columbia, SC. April 1980.

The Committee, at this time,...nor did it consider arguments related to the support of or opposition to such issues as... low-level waste disposal in SC.

Regulation of Federal Radioactive Waste Activities. Report to Congress on Extending the Nuclear Regulatory Commission's Licensing or Regulatory Authority to Federal Radioactive Waste Storage and Disposal Activities. U.S. Nuclear Regulatory Commission. Office of Nuclear Material Safety and Safeguards. September 1979. (NUREG0527 and Summary).

Appendix A - listing and inventory of DOE waste storage, disposal, and processing activities includes Savannah River Plant ( $\mathrm{p} \cdot \mathrm{A}-6)$; where low-level waste are burled in the 200 area. Appendix B - DOE site description includes SRP at B.15 (p.B-43). Site description, and waste activities summary and description are outlined.

Review of "Draft Report of (DOE) Task Force for Review of Nuclear

Waste Management." Document DOE/ER-0004/D dated February, 1978

(DOE Waste Report). Final Report. Governor's Task Force on

Advanced Nuclear Systems. State of South Carolina. June 1, 1978. In summary,..."soine states prefer to continue to permit private operation of low-level waste burial grounds. Final DOE waste program plans should continue to enable this, and to permit 'Agreement States' regulation of low-level waste burial grounds on a cooperative basis with federal authorities." This report also contains Appendix-1 briefly describing the successful experience which SC has had with low-level radloactive waste. disposal.

A State-of-the-Art Report on Low-Level Radioactive Waste Treatment. Dak Ridge National Laboratory. Chemical Technology Division. September 1980. (ORNL/TM-7427). Appendix A "incinerators in radioactive service include Westinghouse Nuclear Fuel Division in SC." Appendix B "representative liquid-waste treatment systems at selected DOE sites..." Include the Savannah River Plant (p.132-5). 
Study of Chemical Toxicity of Low-Level Wastes. Main Report. General Research Corporation; U.S. Nuclear Regulatory Commission. Division of Waste Management. November 1980. (NUREG/CR-1793. Vo1.1). Issues regarding shallow land burial sites $(p .2+)$ "in the Spring of 1979, South Carolina halted shipment of organic iiquid wastes... on the grounds that the material -- as distinct from the radioactive materials itself -- was a threat to the environment." Table 2-6 (p.30) shows volume of non-fuel cycle waste recelved at SC burial site in month of March 1975 thru Dec. 1977. Table 4-2 (p.86) gives present status of licensing of commercial burlal sites including Barnwell 1isting operator, ownership, activities licensed by NRC, activities licensed bri state. Table 4-3 (p.89) details commercial burial site waste inventories (as of $1 / 1 / 79$ ). Appendix 6 - environmental monitoring and the Barnwell Facility Program.

"Super Cemetery," by T.C. Langford, Jr., Up date (South Carolina Department of Health and Environmental Control) vol. 10, no. 4, Fal1 1980.

This article gives overview of Chem-Nuclear disposal site operation and inspection techniques. With reference to the closing of other disposal sites. . concerned legislators. . . use it as a model as they consider their plans for similar sites. This situation gives South Carolina a unique role to play in helping to determine the future path of nuclear waste disposal for the entire nation.

Survey of Current State Radiological Emergency Response Capabilities for Transportation Related Incidents. Indiana University. School of

Public and Environmental Affairs; U.S. Nuclear Regulatory Commission. September 1980 (NUREG/CR-1620).

Chapter $3 . \overline{0}$ contalns question-by-question summaries of the survey data. Response from SC only in area of agents providing radioactive materials emergency response training. In $\mathrm{SC}$ the agencies involved include state and local police; local firemen; rad health personnel and $\mathrm{CD} /$ emergency services.

System Analysis of Shallow Land Burlal. Appendix. Sclence Applications, Inc.; U.S. Nuclear Regulatory Commission. March 1981. (NUREG/CR-1963. Vol. 3).

Appendix A - Site visits includes A-2, site visit to Barnwell; Oct. 31, 1979 press release from Barnwell; voluide limitation schedule and license $\$$ |⿰997 for Barnwell dated 10/30/79. 
System Analysis of Shallow Land Burlal. Technical Background. Science Applications, Inc.; U.S. Nuclear Regulatory Commission. Division of Waste Management. March 1981. (NUREG/CR-1963. Vol.2).

Barnwe11, SC is included in Section 2: site description. Information covers location, topography and climate, and geology and hydrology. Table 5-6 (p.5-33) gives statistics on occupational exposure for various types of personnel at Barnwell, 1978.

Task Force on Low-Level Radioactive Waste Disposal. Final Report. National Governors' Association. Washington, DC. August 1980. In July 1979, the Governor(s) of... South Carolina... operating commercial low-level waste disposal sites, became concerned about the threat to public health and welfare posed by improper packaging and unsafe vehicles... Until recently, Barnwell accepted low-level waste without restriction, annually receiving in excess of $75 \%$ of the nation's commercial wastes...since mid-1978, SC has limited waste. receipts at the Barnwell site to 2.4 million $\mathrm{ft}^{3} / \mathrm{yr}$. On Oct. $31,1979 \ldots$... phased schedule to further reduce that limit to 1.2 million $\mathrm{ft}^{3}$ within 2 years. Because it is geologically unacceptable, SC also prohibits the burial of organic chemical waste which comprise a large fraction of the wastes generated by hospital, medical schools, and universities. SC has also refused to accept any waste from certain generatore with rec ords of poor packaging or shipping practices. Based on projected increases for 1980, Barnwell and sites in NV \& WA can handle; but by 1990 with others closed only Barnwel1 will remain. Then five more sites will be needed.

Technology, Safety and Costs of Decommissioning a Reference Low-Level Waste Burlal Ground. Battelle-Pacific Northwest Laboratory; U.S. Nuclear Regulatory Commission. Office of Standard Developments. June 1980. (NUREG/CR-0570, Appendix, Vol.2).

Site at Barnwell, SC listed in Tables B. 1-2 and 1-3 showing radioactive waste burled at commercial sites as of $12 / 31 / 76$ and comparison of annual volumes of radioactive waste...1974 -1977 respectively. 
"Three States Take Initiative in Low-Level Waste Control," Nuclear Industry. January 1980 .

On Oct. 12, (1979) South Carolina initiated a sequence of steps limiting the availability of the Chem-Nuclear Systems, Inc. at Barnwell by banning further shipments of low-level waste from Comm. Ed. Co. of Illinois. On Oct. 30, (197.9) H.G. Shealy, Chief of SC Bureau of Radiological Health amended Chem-Nuclear's operating license for Barnwell. The imbalance (the closing of Beatty and Hanford with limits at Barnwell) has resulted in SC receiving approximately 80 percent of the total low-level waste generated in this country.

Transportation Issues Regarding Low-Level Nuclear Waste. Teknekron, Inc. U.S. Department of Transportation. Office of Intermodal

Transportation. June 1979. (DOT-P-10-79-25).

Report presents projections of annual amounts of government and commercial LLW. Describes present status at 3 existing burial grounds including Barnwell, SC. Authors assess the transportation effects of regional constraints on LLW management thru 3 scenarios. Case A assumes the status quo, with a restriction on receipt of wastes at Barnwell continuing indefinitely. Case $\mathrm{C}$ assumes that administrative restrictions on Barnwell is lifted. Table 2 shows government LLW generated in 1985. Table 4 gives figures on commercial waste streams generated in 1985 (by region, ie. Southeast and source, ie. university).

Transportation of Low-Level Radioactive Waste Into South Carolina.

October 1978 - Septenber 1979. State of South Carolina, Bureau

of Radiological Health; U.S. Nuclear Regulatory Commission. Office of State Programs. Apri1 1980. (NUREG/CR-1434).

The Chem-Nuclear System, Inc. low-level radioactive waste burial site located In Barnwell County, SC was receiving approximately 80 percent of this type of waste generated in the U.S. Major highway routes used by carriers of low-level radioactive waste shipments in SC were identified during the study. The origins of the wastes, types and conditions of packages and contalners as well as compliance with existing regulations was determined. 
Transportation of Radioactive Materials in South Carolina. SC Department of Health and Environmental Control. Division of Radiological Health. Columbia, SC. January 1975.

"In addition, the shipments of low-level waste to Chem-Nuclear Systems, Inc. for land disposal has increased significantly during the past year."

"Two Sites Shut: Governors Criticize Low-Level Packaging," Nuclear Industry. November 1979.

"Incidents with those (shipments) improperly packaged have generated a lot of political heat in South Carolina... problems stemming from improper low-level packaging and transportation got rolling in July...SC Governor Richard Riley wrote a letter to the NRC and DOT, demanding that they develop a detailed plan to upgrade inspection and enforcement of shipments ...In SC, 63 deficiencies were found in 43 shipments...there is sentiment in SC that it is unfair for those states (WA \& SC) to accept low-level waste for all 50 states..." 
APPENDIX B: General Bibllography

$\cdots$

$\alpha$

$\Omega$ 
Addressing Public Concern In Siting a Reglonal Low-Level Radloactive Waste Facllity. Waltham, MA: Energy Research Group, Inc. February 1981.

A Classification System for Radioactive Waste Disposal - What Waste Goes Where? Ford, Bacon \& Dav1s Utah; U.S. Nuclear Regulatory Comm1s8ion. July 1978. (NUREG-0456; FBDU-224-10).

Docket Book, (Fourth Meeting, Arlington, VA: Sept. 8-9, 1980); (F1fth Meet1ng, Phoen1x, AZ: Jan. 8-9, 1981); (Inter1m Report, Feb.24, 1981). State Planning Council on Radioactive Waste Management. Washington, DC.

Evaluation of Alternative Methods for the Disposal of Low-Level Radioact1ve Wastes. U.S. Nuclear Regulatory Commission. Low-Level Waste Branch. July 1979. (NUREG/CR-0680).

Identification of Technical Problems Encountered in the Shallow Land Burlal of Low-Level Radioactlve Wastes. Evaluation Research Corporation; Oak Ridge National Laboratory. March 1980. (ORNL/ SUB $/ 80-13619 / 1)$.

Low-Level Radioactive Waste Management. Proceedings of Health Physics Soclety, 12th Midyear Topical Symposium. February 11-15, 1979. U.S. Environmental Protection Agency. Office of Radiation Programs. May 1979. (EPA 520/3-79-002).

Low-Level Radloact1ve Waste Management Report. Response to Public Law 96-573, the Low-Level RadloactIve Waste Pollcy Act. U.S. Department of Energy. March 13, 1981 . 
Low-Level Radioactive Waste Technology. A Selected Annotated B1bliography. Vol. 2. Oak Ridge Laboratory. October 1980. (ORNL/ EIS-133/V2).

Low-Level Waste Management: A Compllation of Models and Monitoring Techniques. Volume 1-3. Sclence Applications, Inc.; Oak Ridge National Laboratory. Apri1 1980. (ORNL/SUB-79/13617/2; SAI/OR565-2).

Low-Level Waste: A Program for Action. Final Report of the National Governors' Association Task Force on Low-Level Radioactive Waste Disposal. Nat1onal Governors Association. August 1980.

Management of Low-Level Radioactive Waste. Volumes 1 and 2. Edited by M.W. Carter, et al. Based on papers presented at a symposium sponsored by Georgia Institute of Technology and others. May 23-27, 1977. Atlanta, GA. New York. Pergamọn Press. 1979.

Managing Low-Level Radioactive Wastes: A Proposed Approach. EG\&G Idaho, Inc.; U.S. Department of Energy. August 1980. (LLWMP-1).

NRC Task Force Report on Review of the Federal/State Program for Regulation of Commerclal Low-Level Radioactive Waste Burial Grounds. U.S. Nuclear Regulatory Commission. Office of Nuclear Material Safety and Safeguards. March 1977. (NUREG-0217).

NRC Task Force Report on Review of the Federal/State Program for Regulation of Commercial Low-Level Radioactive Waste Burial Grounds. Analys1s of Public Comments. U.S. Nuclear Regulatory Commission. Office of Nuclear Material Safety and Safeguards. October 1977. (NUREG-0217. Supp.1).

Need for Greater Regulatory Oversight of Commerclal Low-Level Radioactive Waste. Report by the U.S. General Accounting office. August 16, 1978. (EMD-78-101). 
The 1979 State-by-State Assessment of Low-Level Radioactive Wastes Shipped to Commerclal Burlal Grounds. San Francisco, CA: NUS Corporation. November 1980.

The Nuclear Regulatory Commission Low-Level Radioactive Waste Management Program. U.S. Nuclear Regulatory Commission. Office of Nuclear Materlal Safety and Safeguards. September 1977. (NUREG0240).

Nuclear Waste Disposal. Hearings before the Subcommittee on Nuclear Regulations. Part I. U.S. Congress, Senate. Committee on Environment and Public Works. 96th Congress, lst Session, Sept. 11 and Dec. 11, 1979. (Ser1al No. 96-H27).

Nuclear Waste Disposal. Hearings before the Subcommittee on Nuclear Regulations. Part II. U.S. Congress, Senate. Committee on Environment and Public Works. 96th Congress, 2nd Session, Jan. 23-24, 1980. (Serial No. 96-H27).

Nuclear Waste Fac1lity S1ting. Oversight Hearing before the Subcommittee on Energy and the Environment. Session on Public Participation and Equity in Nuclear Waste Facillty siting. U.S. Congrcss, House, Committee on Interlor and Insular Af fairs. 96th Congres8, 1st Session, June 28, 1979. (Sertal No. 96-8. Part V).

Prellminary State-by-State Assessment of Low-Level Radioactive Wastes Shipped to Commercial Burlal Grounds. Rockville, MD: NUS Corporation. February 1980 .

Programmat1c Assessment of Radloactive Waste Management. Nuclear Fuel and Waste Programs. Glibert/Commonwealth; Oak RIdge National Lahoratory. June 1980. (ORNL/SUB-80/13837/3). 
The Problem of Disposing of Nuclear Low-Level Waste: Where Do We Go From Here? U.S. General Accounting Office. Report to the Congress by the Comptroller General of the Unfted States. March 31, 1980. (EMD-80-68).

Report of the Task Force on Low-Level Radioactive Waste. United States Radiation Policy Counc1l. August 1980. (RPC-80-004).

Screening of Alternative Methods for the Disposal of Low-Level Radioactive Wastes. Ford, Bacon \& Davis Utah, Inc; U.S. Nuclear Regulatory Commission. October 1978. (NUREG/CR-0308).

Shallow Land Burlal of Low-Level Radioactive Waste. A Selected, Annotated B1bliography. Vol. 1. Oak Ridge National Laboratory, Ecological Sclence Information Center. September 1978. (ORNL/ EIS $-133 / \mathrm{V} 1$ ).

A State-of-the-Art Report on Low-Level Radioact1ve Waste Treatment.. Oak Ridge National Laboratory. Chemical Technology Division. Septem̈ber 1980. (ONNL/TM-7427).

State of the Art Review of Alternatives to Shallow Land Burial of Low-Level Radloactive Waste. Gilbert/Commonwealth; Oak Ridge National Laboratory. Apr11 1980. (ORNL/SUB-79/13837/1).

Study of Chemical Toxicity of Low-Level Wastes. Maln Report, Vo1. 1; Monographs, Vol.2. General Research Corporation; U.S. Nuclear Regulatory Commission. November 1980. (NUREG/CR-1793).

System Analysis of Shallow Land Burial. Code Manual. Vol.1; Technical Background, Vol.2; Append1x, Vol.3. Sclence Applications, Inc. U.S. Nuclear Regulatory Commission. March 1981. (NUREG/CR-1963). 
Technology, Safety and Costs of Decommissioning a Reference Low-Level Waste Burial Ground. Maln Report and Appendices. Vols. $1 \& 2$. Battelle-Pacific Northwest Laboratory; U.S. Nuclear Regulatory Commission. June 1980. (NUREG/CR-0570).

Understanding Low-Leve1 Radloactive Waste. EG\&G Idaho, Inc; U.S. Department of Energy. November 1980. (LLWMP-2). 
APPENDIX C: Selection of Newspaper Articles 
May 10,1981

\section{Hazards come with age at Savannah nuclear plant}

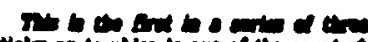

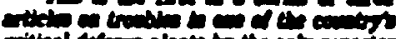

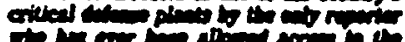

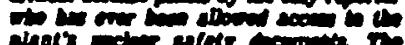

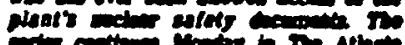
sime

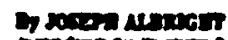

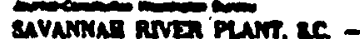

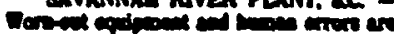

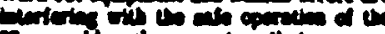

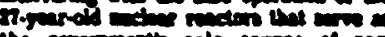

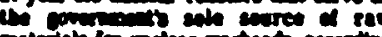

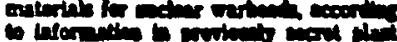

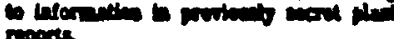
more.

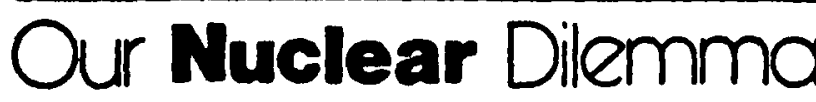

\section{Part $V$ The Safety Problem}

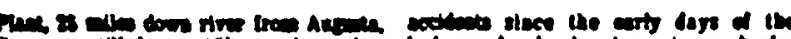

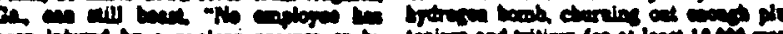

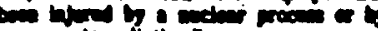
perate netintion

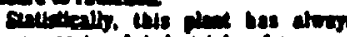

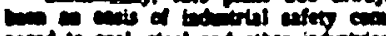

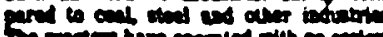
mant

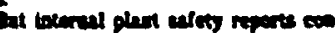

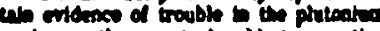

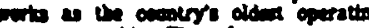

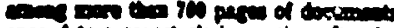

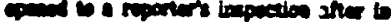

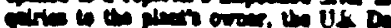
mone al bors.

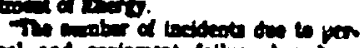

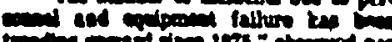

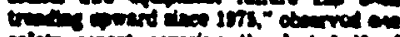

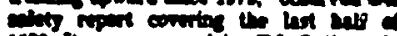

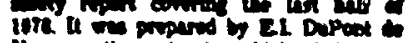

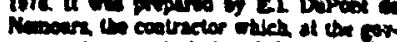

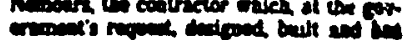

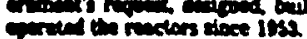

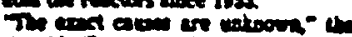

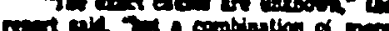

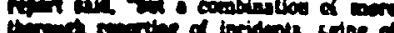

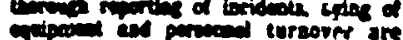

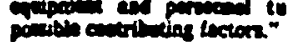

En Nuaria ite

\section{Nuclear contmoson mon n}

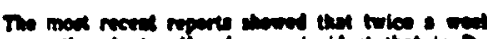

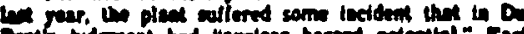

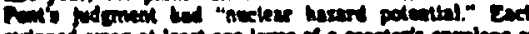

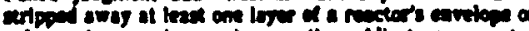

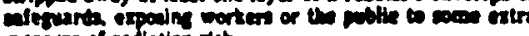
mencose of endiclion ret

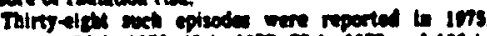

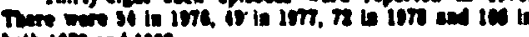
coth 1979 and ines.

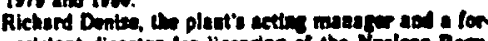

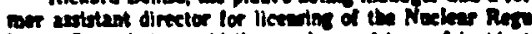

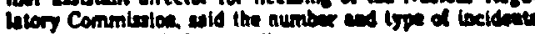
ool considend alemine.

"Dw number of reacto incleat mports bes nown

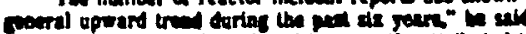

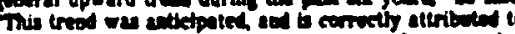

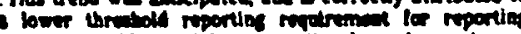

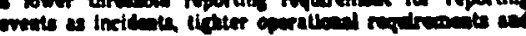
arscinet tornows.

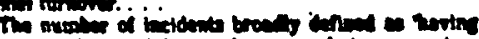

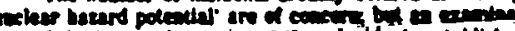

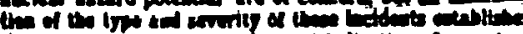

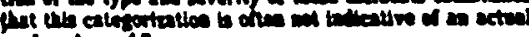
melem basm

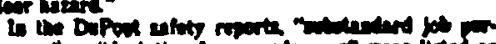

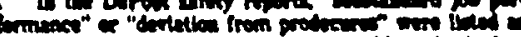

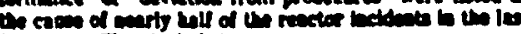
ive year $\mathrm{Tm}$ bectore

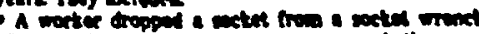

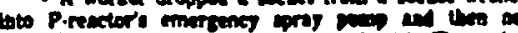

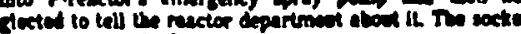

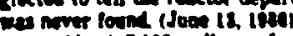

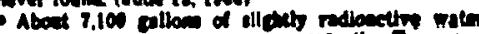

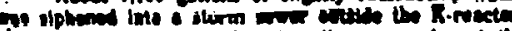

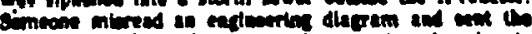

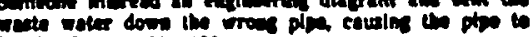
inent. (Jemeng 24, iste)

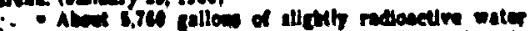

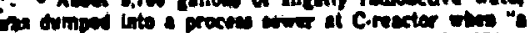

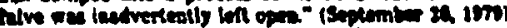

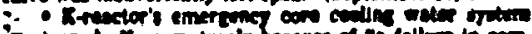

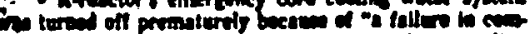

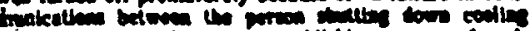

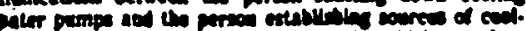

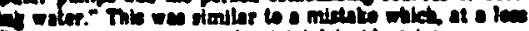

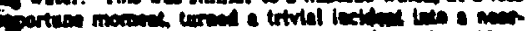

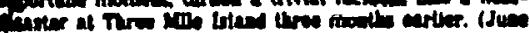
Qinis)

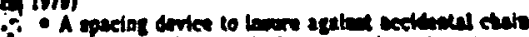

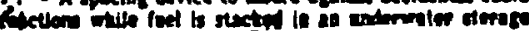

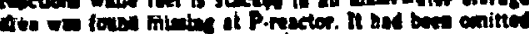

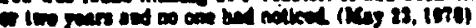

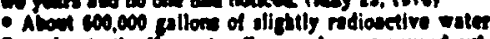

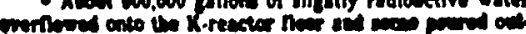

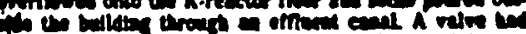

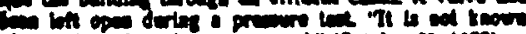

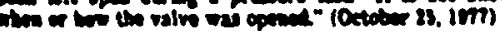

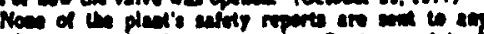

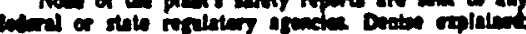

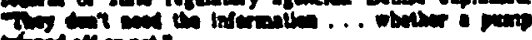

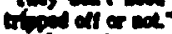

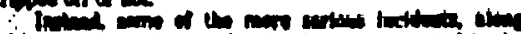

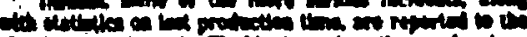

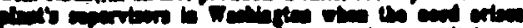

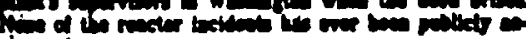
ind

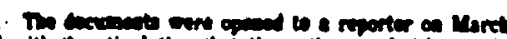

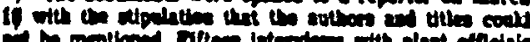

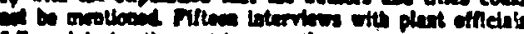

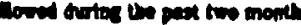

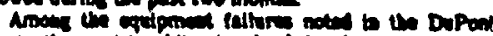

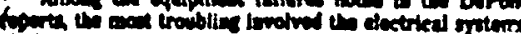

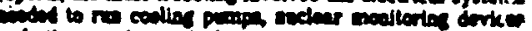

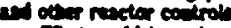

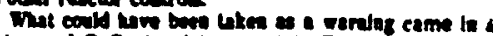

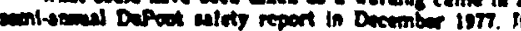

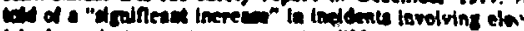

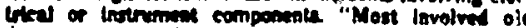

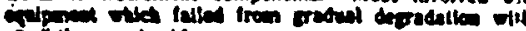

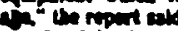

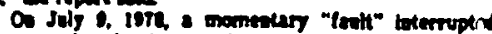

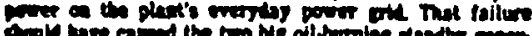

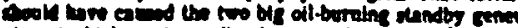

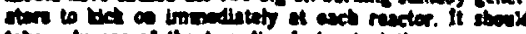

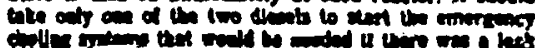

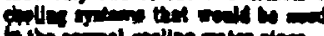

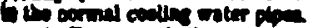

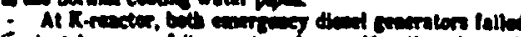

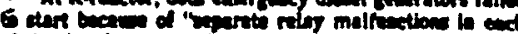

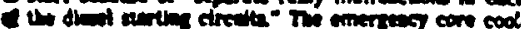

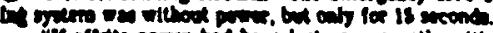

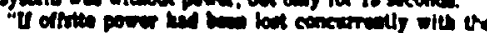

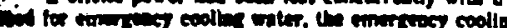

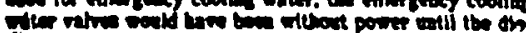
- zomeratoss could buve been placed oalime manually. -

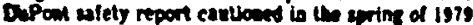

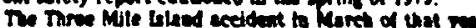

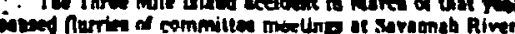

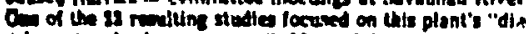

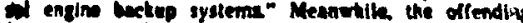
componemes in R-reactor's diesel starting etroult were ne

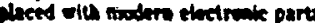

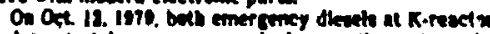

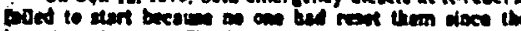

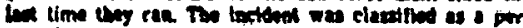

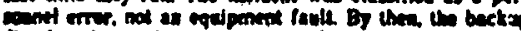

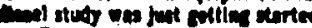

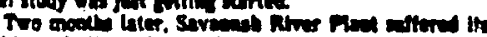

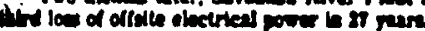

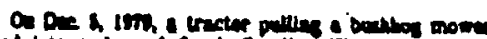

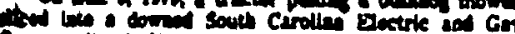

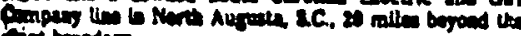
ind bons.

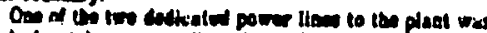

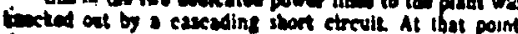

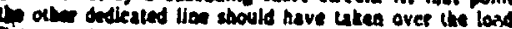

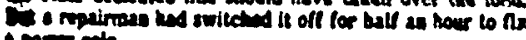
- compera pole

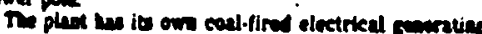

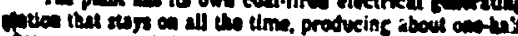

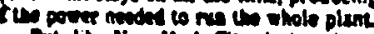

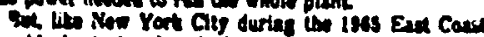

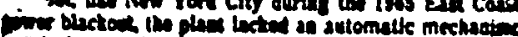

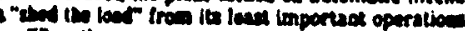

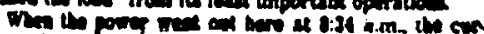

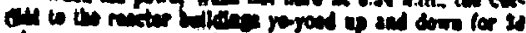

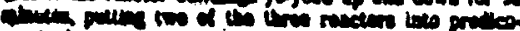

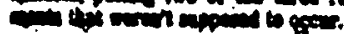




\section{Radioactivity means a cross.}

- Dotclass dattoor gulf woter

Heatord Wash. and Beatts. Nov. - Cown th the spariety

cilitid Amertean weat - ore hirdy dimour eapleats of America

But that gees on th ihoeg for.

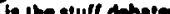
away lows is the surt dabate. in North Caroline are made of. In typieal prar, more than cining low.tent prims con waste are shipged to llantor - Besily irom laboratories i ive Researea Trtangle of Nort Carolins. intervien eontucted by The Cary Nomeshow.

Hanford and Beatry ars locfuone of low-love two of only three areh sila in Uiv United siate

The thind site, as Bermute to Sounh Carolins, is not often used oy Recesreh tritangle lab beesua miny tab miterlat butial in the soll at Bamwell.

Lob wasto typically inelud staesware. paper lowels. nimal curcassea - anylhina in a modem laboratory that couid come in contact with experinamention.
The waster are placed in arum and packed with at

in the ritanges.

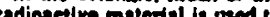
trace the properes of drusp leboratery enimals.

shipoling the drume out wed is in erpensive ontelion couling obout kmo op orum. Univerally. ome of the moje Univeraliy. mo of us maje Durham countie

But the durne may nox bo shipped to Whathingen mus longer. A statewide referendur posead last November wi cradually clese the Hanford reestion over the mant two year. to sll newp ta.tuste product. of low invit radianetive waste.

Political aettors such as those

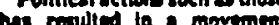
nas rovulied to a movomim public offieist to explors the

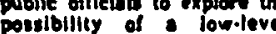
radioactice waste burtal sile in the Triasle Batin - a band of dmes elny running immugh Westem Wake County. Durham Couniy. Orante County. County.
Such a burial ute could be a onlutinn. covernment and privale afficials wy. 10 . pmilem whseh threstens the ires's reacarch exemomy.

Escablsshment of a site could ito hame the uste's preatits when looking for intustry. on imeneirial inflicisi and

but environmmital eroup cald at o public mmeting in Raluifh liat wook that tha stite ahruld lieccursase hizaminas and low. Irvel wasle produring
firms from seting in Ninth Caroline.

In Wake and Durham countien, is racilities nold is suraissted licemses to handle cadioactive moterials which could result in semeration

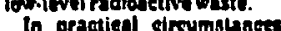
though. onty eloum Pacilities aelualiy produes low.level waste in un twocounty area. put thase fectlitie inctude major employers in the majar empe. like Lute. $N$ C. Suate Univertity. sate covomment and hom of tactlitice o Rescareh Triangle Part.

Uuke. Ine exaingle. shlpo - bont 100 horrels per monih to Monford. soid Dave Jorgensen, officer.
Duke is also the agent for the Piedmant Carolina retion at ine American Red Creose based in Durtum, sald Don Bennett. the

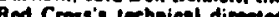
in Uurham.

the Red Crow protuce hout 12 dnums a var of ine Irvil radianelive waste in the courne of its testing (or hegatilis orih. Uurham foeility. Bennet A third hermahoiner In Durham is N.C. Centrol

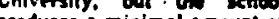
protuces minimai amount of ese than radlosctiv waskelese than one. cubte rook in year - said Dayme Brown, head of the state's Radiation In Wake Coumty, there are Chree licensoholders permitie

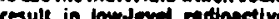
reste

But one of tha llesenes haldere Dulpone of clually use it mileriais on ter in Juhnaton couniy neer com in sind Chuek Evam, member of Hrnwn'e siall.

Herhicides and pestleidea are insed un the Jahnston County firm by the DuPent chemical lirm. Evans suid.

The lwo other liceneotrotden

\section{-country journey for wastes}

in Wike Cousty in both branche of itste covommenth Tho Clale Degartumen of liuman Rmaures uece saveral modiactive materiats in lis divisions of health and mentil neslth, Mid

Phyietst.

But $m$ soid Ilttle

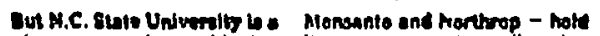
majop wasle moduerr, shipping out coout 120 drums of redioactive wesle per vear. by Brown.

Miany waste produeen ore located in Mepente tranyle Park.

But two noms in the part -

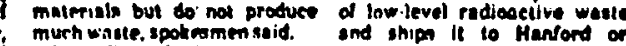

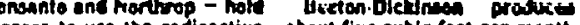
miminls but do not protive ahoul five cublc feet per month Cllhre firms do ship oul wate. Mristy. a spohemman said. Chrmical Instilute of A spokesman for Researen Poxicutary shipe ahout two Truankle Institute declitied to doums of radinative whste per spreity how much low.level

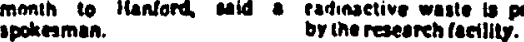


The recent interim report of the State Planning Council on nuclear waste was important beyond its helpful suggestion. for a cooperative federal-state management effort.

The main thing was its strong suggestion that the government place . primary emphasis on permanent disposal of high level waste.

That puts the planning coun. cil, headed by South Carolina's Gov. Dick Riley, a Democrat, on the same general track with Energy Secretary Jamies Edwards, a key Republican. Not long ago, the secre tary indicated his desire for emphasis on permanent storage when he opposed temporary away-from-reactor storage of high level waste because that would delay a decision on permanent storage.

Therefore. the two statements indicate the possibility for an early national concen. sus and a bipartisan approach to high-level waste marlagement.

Riley's statement to the nation's governors was interesting for another reason: It recommended a federal-state partnership on waste management, which he said would mean "there can be neither arbitrary imposition of federal will nor arbitrary actions by the states to block waste mun. ugement declsions."

The Riley report included discussion of other nuclear wiste matters, such as statie reponsibility for low-level waste disposal, and transportation of nuclear refuse. But emphasis on a national plan for high-level waste was the most significant point. Like Secretary Edwards' testimony, it focuses on the need for a decision which, as the secre. tary said. "we've put off for 30 years."
Signs of a possible consensus on developing a policy are encouraging because at best it will be difficult to reach a final decision on permanent storage of high level nuclear waste. No state wants a nuclear waste disposal site. even though there are ways to solidify the material for storage in places well away from large bodies of either surface or ground water.

The necessity for permanent disposal is clear. It is unsafe to continue keeping long-lasting. dangerous radioactive wastes in temporary tanks close to major aquifers. The presence of more than $25 \mathrm{mil}$. lions of gallons of waste on the Savannah River nuclear reservation in South Carolina threatens an aquifer underly. ing parts of at least two states.

The planning council report points the way toward a final decision: "consultation and concurtence among public officials, all of which is intended to arrive at a consensus as to where and how the waste is buried." The process would entail participation by elected officials "at all levels of the federal system."

The tenor of the interim report argues for continuation of Gov. Riley's leadership on the council, especially in view of his important role in estab. lishing a national policy on low-level nuclear waste management.

The nation needs the cooper. ative efforts of Democrats like Riley and Republicans like Edwards in order to solve the nuclear waste problem. Both have dealt with it at close range as governors of a major nuclear state; and now are in position to influence the inner workings of the administration and Congress. 


\section{NRC Eases Nuclear Waste Rules}

\section{Wassinoton Pos:}

WASHINGTON - The Nuclear ReguTatory Commission (NRC) has declared that irradiated animal carcasses and some laboratory equipment no longer must be classified as low-level nuclear waste.

The action affects about $15 \%$ of the country's low-level nuclear waste, which may be buried at only three sites - in Washington State, Nevada and at the Chem-Nuclear dump near Barnwell, S.C.

The ruling means carcasses and vials in which irradiated tissue is tested can be burned or buried in ordinary landfills.

This will save hospitals and research laboratories $\$ 13$ million annually in transport, packaging and disposal costs while posing no danger to the public, the NRC said.

(David Ebenhack, health and safety manager at the Barnwell dump, said the decision will have little effect on the facility because it receives few animal carcasses and stopped taking some hospital waste in 1979.)
The NRC also increased the amount of radioactivity that can go into sewerage systems, calling the increase from one to six curies "a negligible addition to the amount of radioactivity from these materials already present in the natural environment."

An estimated 80,000 cubic feet of burial space at existing low-level waste cumps is used every year for 55-gallon crums containing carcasses of rats, mice and other animals in which radioactive trace elements have been used to help study the effects of experimental drugs.

Another 400,000 cubic feet is taken up by drums containing vials in which the animals' blood or tissue was analyzed.

These two items comprise half of all medical radioactive waste.

Richard Cunningham, director of the NKC's fuel cycle and material safety division, said the rest is X-ray film, wiping rags and other materials. All contain "very low levels" of radioactivity, he said.

A person living about 125 feet downwind of an incinerator burning carcasses and vials from a major hospital, he said. would receive 1 millirem of additional radiation a year. $A$ coast-to-coast round trip by jetliner gives 3 millirems of radiation.

"Historically, it was cheap and simple to send everything to a waste burial ground." Cunningham said. About two years ago, however, disposal costs and transport charges began rising as burial space dwindled, and the three burial sites closed down tcmporarily to protest lax federal enforcement of waste packaging rules.

"At that point, the labs recognized. this as a problem, and we did, too," Cunningham said. Burial often posed difficulties because decomposition gases occasionally ruptured buried drums. The new policy will solve those problems by permitting conventional disposal methods to handle the wastes, Cunningham said. 
Mar. 31, 1981

\title{
States Grapple With Mandate To Dispose of Atomic Waste
}

\author{
By sen sem
}

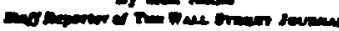

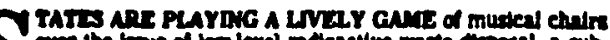

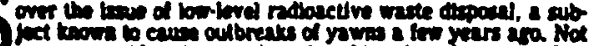

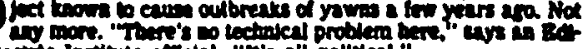

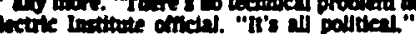

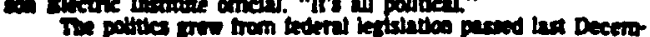

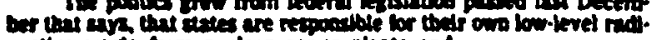

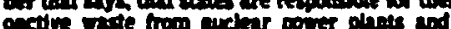

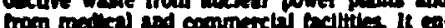
cournes liem to form tererrite compacts

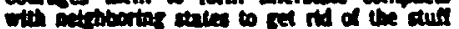

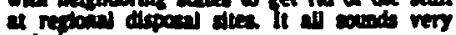
andity.

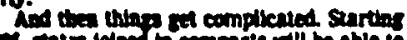

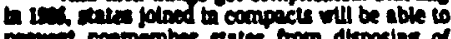

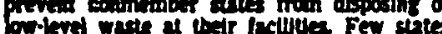

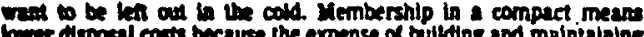

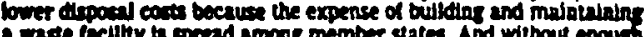

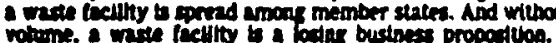

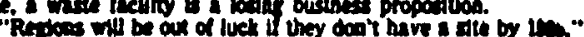

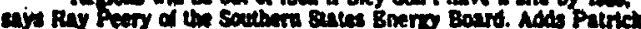

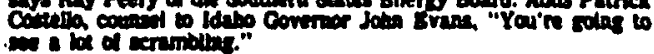

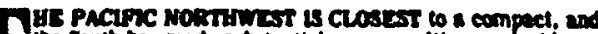

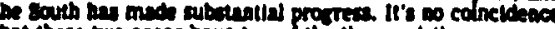

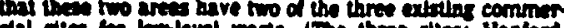

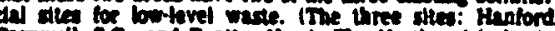

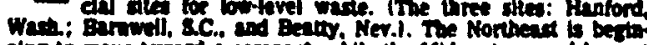

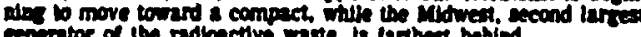

The drgex cumbling block, predtecubly, ts the focation of dis.

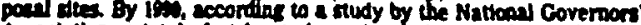

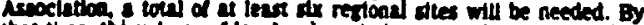
chat om. in volume of bow.leve wate is expected to be more than

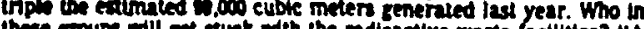

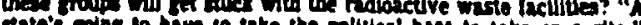

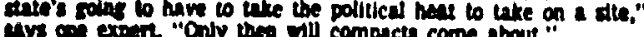

A how males-reme, Marrachusets, Karas and Virginda

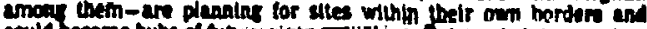

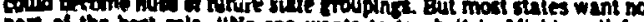

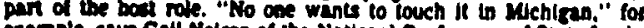

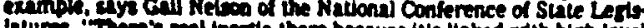

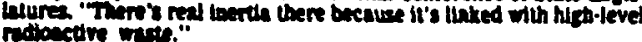

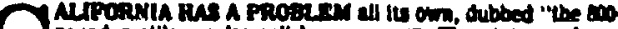

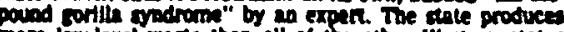

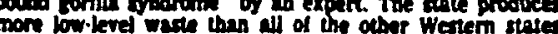

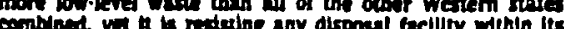

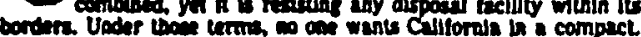

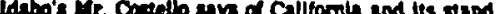

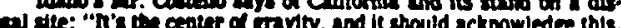

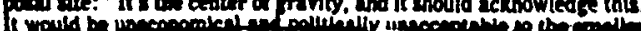

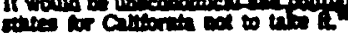

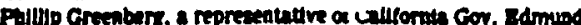
Brown. coasedes the state's poeflion is "awtwrard." particularty in rendi tollow throus on cor. Robert Un's promise to chen the

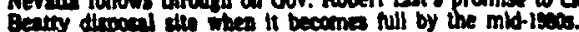

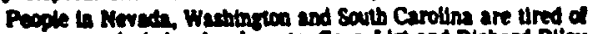

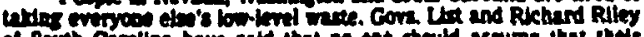

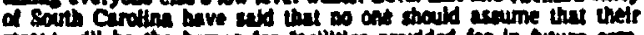
antes wil be the lane for nellitios provided for to heture com.

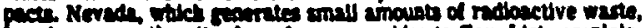

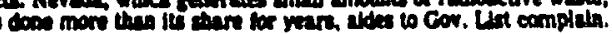

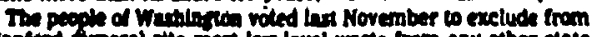
The ringed

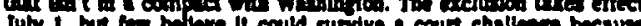

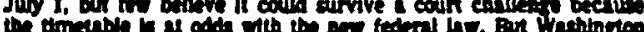

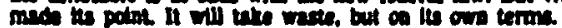

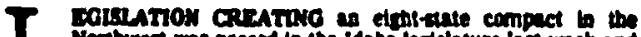

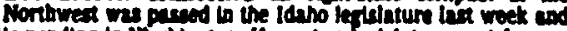

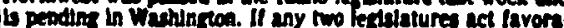
thy be the

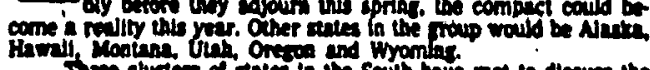

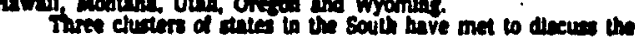

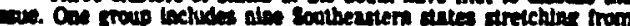

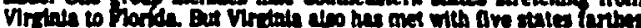

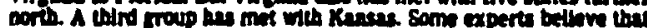

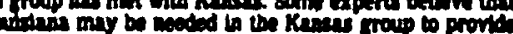

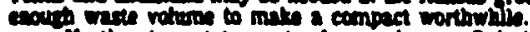

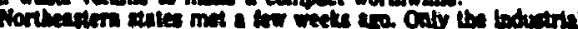

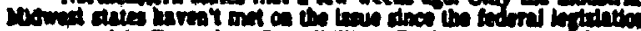

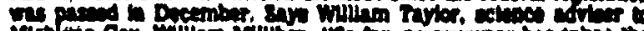

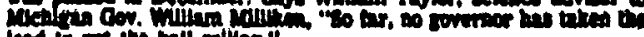
hed to on the bell riliog." 
MONTEREY, Calif. - "Regional initiatives" may not sound, like a titillating topic, but the executives of the American Nuclear Society who met last week in this northern California town known for it's sparkling bay and Spanish-style adobe houses found it fascinating.

South Carolinians should, too.

The society's nuclear engineers and industry executives learned that "regional initiatives" on nuclear waste disposal are at last going forward. If they are successful, it will mean that the increasingly heavy burden of disposing of most of the nations low-level nuclear garbage finally will be spread around and will no longer tall disproportionately on the Palmetto State which had been accepting upwards of 80 percent of the stuff.

SHARING THE BURDEN was mandated by federal legislation pushed by S.C. Governor Dick Riley and passed in Decemeber of 1980 . Each state now has the responsibility for burying Its own low-level radioactive waste; the states have been authorized to form regional compacts to dispose of that waste.

Nine states attended a meeting in Columbla called for. just this purpose on Jan. 5 . Six states plus the District. of Columbia attended a meeting called by Gov. John Dalton of Virginia on Jan. 6.

Regional compacts are not being discussed only in the South, the American Nuclear Society was told. The northwest tier of states held the planning session in January in preparation for a second regional conference held this month in Seattle.

In the Midwest, discussions among several states have been under way since early 1980.

In the West, the Western Interstate Energy Board and the Council of State Governments are playing active roles in that region's efforts.

In the Northeast, the New England Regional Commission has begun a study of the options for a regional compact.
THESE STATES are acting quickly not only because of the new federal legislation, but also because time is of the essence.

The only states with sites where commercial low-level waste can now be buried are Washington, Nevada and South Carolina. But Washington voters approved a referen. dum on Nov. 4 to close the disposal site at Harford to out-of-state nuclear garbage beginning next summer.

The governor of Nevada has vowed to close that states' dump at Beatty, while Governor Riley is cutting the amount by half of nuclear trash that the Barnwell, S.C.. site accepts.

The other states in the country realize that they must

act now or possibly be left out in the cold. with large amounts of nuclear waste and nowhere to bury it.

BUT THE ISSUE is as politically sensitive in other parts of the country as it is in South Carolina. Tase Illinois for example. "Many people there belleve It's al! right for us to take care of our own low-level waste," says Phil Gustafson, a nuclear physicist who now works for the state of Illinois. "But many people draw the line at accepting waste from other states. It's not going to be easy."

The Midwest and Northeast states - both of which generate large amounts of nuclear waste - will be crucial to the success of the regional compact idea being pushed by Governor Riley.

There seemed to be an increasing realization among the American Nuclear Society members that the issues here are primarily political, and not technolofical. The techniques to safely dispose of low-level waste may be on hand, but the problem is getting people to believe it and to accept it in their own back yards. 
THE CHARLOTTE OBSERVER

Feb. 17,1981

\section{Duniping Upposed}

$\Lambda$ plan to ship two low-level radioactive steam gencrators to the Chem-Nuclear Services Inc. hurial site at Barnwell, S.C.. has drawn opposition from the Palm. ctto Alliance. The total amount of radioactivity emitted by the tivo generators being disposed of by Florida Power and Light, Co. would be more than South Carolina allows for radiosctive waste. heing dumped at the site during a vear, a spokesman lor the anti-nuclear alliance said. 
THE RECORD . Columbia, S.C.

Feb. 7, 1981

\section{Group: nuclear waste limit waiver sought}

BY BUNNY RICHARDSON Record Staff Writer

The Palmetto Alliance has charged that the state Department of Health and Environmental Control and Florida Power and Light are privately negotiating to waive the state's limitations on how much low-level radioactive waste can

DHEC attorney Richard P. Wilson said the agency has talked only informally with officials of Chem-Nuclear Systems Inc., who were contacted by FP\&L.

He stressed that FP\&L has nol applied for "a spe. cial permit for a special shipment" and that if a waiver is granted, it would be only for FP\&L and not "a wholsale waiver" of the lim. itations.

The state limits how much waste can be buried each month at Chem-Nuclear's fácility near Barnwell and that amount is being reduced over a period of time. Chem-Nuclear allocates space to the com. panies and utilities that use its burial facility.

FP\&L wants to ship a large volume of waste from its Turkey Point nuclear sta. tion near Miami to ChemNuclear. but it cannol without the waiver because by the time the waste can be shipped, the volume would exceed the utility's monthly location. Wilson said.

It will be more than a year before the waste can be transported because FP\&L must obtain permits from the federal Nuclear Regulatory Commission, he said. Palmetto Alliance spokesman Michael Lowe said the utility plans to replace six steam generators at Turkey Point and wants. to bury 1,200 tons of radioactive stainless steel and other alloys from the generators at Chem-Nuclear.

Lowe fears granting the waiver will increase South Carolina's image "as a radi. oactive graveyard" and he said the alliance coes not want "a precendent set that would allow us to become a handy junkyard for nuclear mistakes."

He said it will cost FP\&L from $\$ 500$-million to $\$ 1$ billion to replace the generators, and he estimated the utility would pay Chem-Nu. clear about \$3 million to dispose of the waste. 
The Reagan administration is considering federal purchase of the privately owned Barnwell Nuclear Fuel Plant, for full scale operations as a spent fuel reprocessing station.

This probably means the plutonium controversy with all its frightful contents is about to hit the national fan again.

Concern about accumulating ieapons grade plutonium that is a by-product of nuclear fuel recycling is legitimate ennugh. There is serious and informed worry, too, about drawing more nuclear wastes to South Carolina on a temporary storage basis with no permanent disposal yet assured.

The time would seem at hand, though, to switch from hand wringing to answer seeking on the fundamental question posed in the Barnwell facility.

After 30 years of developing nuclear energy technology, the resulting buildup of temporarily stored spent fuel demands a solution: either recycling of the spent fuel to reduce the danger it poses, or scuttling of the processes that are adding to this hazardous waste.

A fuel recycling answer was asserted years ago by the Congress and successive administrations. In consequence, three companies joined to form Allied General Nuclear Service, and build the $\$ 280$ million Barnwell facility as a commercial nuclear fuel reprocessing plant.

Former president Ford put it on temporary hold, and Jimmy Carter made the hold a formal national policy, though more than $\$ 10$ million a year in federal funds continues to be pumped into it so keep a cadre of trained people and to maintain a degree of operational readiness.

There are doubts, such as Energy Secretary James Edwards expresses, about the currentness of the Barnwell technology. There are other serious concerns about controlling emmission levels during any full scale during any full scale reprocessing operations.

Other countries, for instance. France, have moved beyond such doubis and are actively reprocessing nuclear fuel. This is not in spite of plutonium fears but because they also are developing plutonium-fueled nuclear processes that are a generation ahead of U.S. technology.

Maybe the French and others are foolish, wasting money or courting disaster. But that is an Issue of discriminating judgment, while U.S. policy is one of paralysis based on fear.

A commitment to federai acquisition and opening of Barnwell would acknowlege the fliel recycling route is probably the only alternative to eventually scuttling nuclear energy in this country.

At bottom, it calls for nothing more than public trust in the competence and prudence of the national administration to proceed with care.

Some people don't have that confidence in anyone who doesn't share their doubts about nuclear energy itself.

These critics deserve to be heard, but not so often agreed with. They have created considerable confusion and distrust, and have pretty much shaped our current nationa! policy of indecision and inaction on fuel reprocessing. 
Feb. 6, 1981
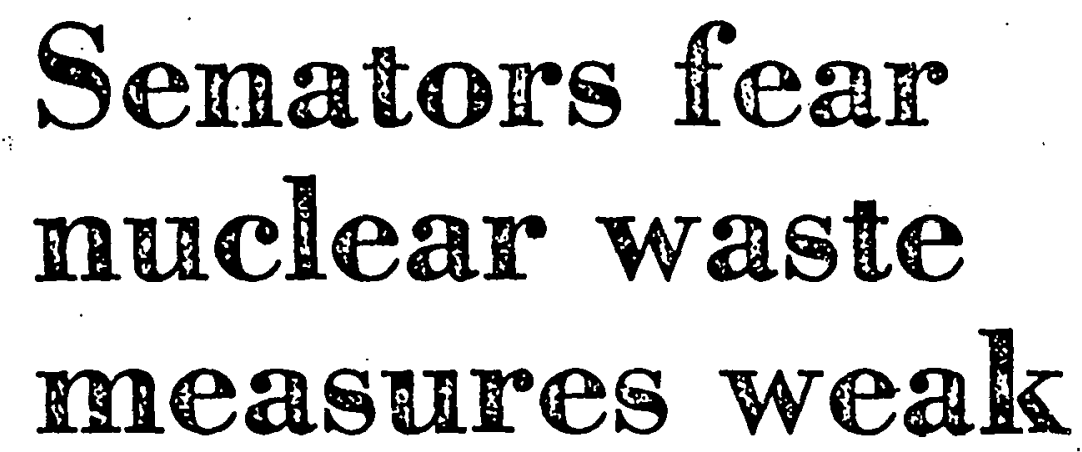

By Ed Vogel

Slaff Writor

CARSON CITY - Several senators Thursday expressed doubts about the strength of legislation designed to manage the now of nuclear wastes to the Beatty dump.

"We're exposing our children and people to health problems nobody else wants," said Sen. Jin Bilbray, D.Las Vegas. "I'n fearful for our people."

Bilbray told members of the Senate Human Resources Committee the bills authored by Sen. Lawrence Jacobsen, R. Minden, were not strong enough. Jacobsen's bills would nat. reduce the amount of low. level nuclear wastes going to the dump near Beatty.

Bilbray said he will introduce legislation allowing only materi. als generated in Nevada to be shipped to Beatty. Consequent. $l y$, no action was taken on Ja. cobsen's five bills.

The Las Vegas senator's com. ments were echoed by Sen. Jim Kosinski, D.Sparks.

"You seem very caln about this," Kosinski told Jacobsen. "I think you'd sell the island for a box of beans."

If shipments of wastes to the Beatty dump continue at the present rate, the facility will be filled by 1985, said Raljh DiSi. bio, the statc Human Resources dirctor. The volume of ship. ments to Beatty has increased by $C 4$ percent over last year, he added.

More and more materials are expected to go to the Nevada dump since voters in Washing. ton state banned out.of.state shipments to their dump.

Officials in South Carolina also soon may reduce the amount of waste going to their facility.

The three dumps are the nraly depositories for commercial low-level nuclear wastes in the United States.

Even more nuclear waste na. terials, however, are shipped to the Nevada Test Site, about 40 . miles down the road from Beatty. These wastes are generated by federal installations and ap. parently are beyond state con. trol.

"It seems like 70 percent of the nation's wastes wili go through Las. Vegas, Reno or Elko," Bilbray said.

However, 75 percent of the nuclear wastes at the Beatty dump could have been disposed of "at your local dump," Jariob. ien said. Most are nuclear medicine wastes from hospitals, he added.

"I didn't see anything more hazarclous there (at Beatiy) than an outdoor outhouso a couple years ago," he added.

Jacobsen pointed out not one Beatty resident objected to the dump when a legislative sub. committee held hearings there.

In addition, Sen. Joe. Neal said Nevadans receive benefils from nuclear energy, such as X. ray machines and hospital iso. topes.

"Surely we wouldn't want to be without them?" asked Neal.

Not only nuclear wastes, but chemical wastes and other hazardous materials should be rog. ulated, added Verne llosse, director of wastes for the state Division of-Environmental Pro. tection.

"We've had problems al. ready" with hazarous wastes, Kosse said. 


\section{FIVE TO 10 YEAR ON-OITE CAPACITY}

\section{AOVIBED FOA LOW-LEVLL WAOTE BTORAOE}

MONTEREY, Calif. - (By a BNA Staff Correspondent) Electric utilitics building nuclear power plants should bo prepared to store low-level waste material on site for at least 10 years because of a posstble shortage of disposal sites, a Department of Enercy official warned here February 2.

Addressing an American Nuclear Society conference oo state and federal roles in waste management, Ceorze B. Levin, program manager of DOF's low-level waste manage. ment program in Idaho, noted that the three existing dis posal sites are adequate for only three more years.

"If I were a utility executive, I'd be concerned," Levio said when asked how low-level waste generators should plan for the future. During the 1970 s the number of disposal sites dropped from six to three, and there is considerable uncer tainty about when new sites will be opened.

Despite his waming to utillties, Levin sald he is optimistic that new sites can be approved and opened in the coming decads. It takes three to five years to complete that procese, he said. But given that lead time and othar uncertaintles of the siting proceas, it is prudeot for utilities to plan for the worst case and be prepared to store waste on site for five to 10 years, he advised.

Levia reported on progress in four studies being conducted by DOJ on low level waste projections for the 1980s. In 1970 , commercially coerated bow-level wate dispoeal ficlitice recelved 2.8 million cuble feet of waste, while DOE dite recelved some 1.8 million cublc feet, he said. The bult of the commercially generated waste, nearly 80 percent, goes to the Barnwell. S.C., site and the rematnder is divided between Hanford, Wash., and Beatty, Nev.

Fully half of the waste is generated from commercial nuclear power plants, Levin reported. Most of the low level waste comes from eastern states, he added, yet Burnwell is the only eastem disposel atte in operation.

\section{DHeposal Blis equear.}

The Barnwell site cradually is reducing the amount of waste it will accept for disposal. Levin sajd. That decision will put more pressure on the Beatty and Hantord sites. In 1982. the Bamwell facility will uccept orly 1.2 million cubic feet of waste.

Previous DOE estimates have put the low-level waste generation rate in 1990 at 11 million cubic feet, Levin said. At that rate, 10 sites the size of Barnwell will have to be in operation, each accepting 1.2 million cublc feet, he explain. ed.

Levin said he believes adequate disposal sites can be found and approved to handle that volume of waste. The six.site network that existed in the early $1970 \mathrm{~s}$ is a good model on which to build, he suggested. Besides Bamwell, Beatty, and Hanford, that network included sites at Sheffield, III., Maxey Flats, Ky., and West Valley, N.Y.

Levin praised the efforts of some states and utilities :0 speed up the siting of disposal sites. A potential squeeze in availablity of disposal sites is recognized by those officials. he said. Most of the sites probably will be located in eastern states, near the waste generation aites. he predicted.

The potential squeeze on existing disposal sites and a need to Insure adequate electric power are combining to force states to confront the low-level waste disposal issue. Jobo J. Stucker. executive director, State Planning Council on Radioactive Waste Managcment, outlined some progress toward siting state and regional disposal facilities.

Legislation enacted by Congress last year orders the states to provide capacity for disposal of low-level wastes generated within their borders, he noted. The law alsn authorizes stutes to enter into compacts with neighborir.s states for regional sites. Preliminary discussions about such regional compacts already are under way in New England, the Midwest, Southeast, and West, he reported.

To assist the states, the State Planning Council is working on a model interstate compact for low-level waste disposal, Stucker suid. It likely will be a few years, however, before any new sites are opened under the authority of an individual state or multi-state compact, he cautioned. The Nuclear Regulatory Commission could facillate such work by es. tablishing uniform, national standards for the states to follow, he suggested. 
Jan: 28,1981

\section{Dripping water not 'hot'}

A truck loaded with low-level radioactive waste headed for South Carolina gave officials a scare Tuesday night when it appeared at a toll booth near New. burg, Md., dripping liquid from its load. But the llquid turned out to be non-radioactive water, and state officials let the truck go on its way.

The driver. Darryle S. Thomp. son of Midland, said the iruck was headed for the nuclear waste dump at Barnwell, S.C. 
Jan. 6,1981

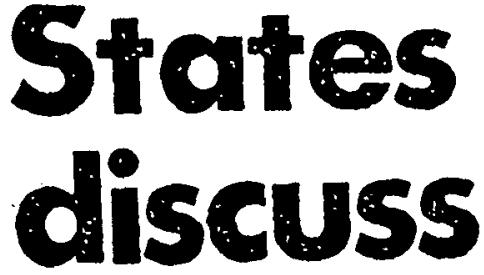
wastes

\section{S. C. wants help with disposal}

COLUMBIA, S.C. (AP) - Representutives of nine Southeastern states agreed Monday to try to establish a pact to handle burial of low-level nuclear waste.

The agreement came during a meeting in Columbia arranged by Gov. Dick Riley. It was the first such gathering in the nation 10 discuss forming agreements under a new law jussed by Congress last month.

David Reid, Riley's energy aide. said Virginia and Kentucky may make an agleement between themselves and with other states. not including South Carolina.

Other states represented in the Columbia ineeting were North Carolina, Alabama, Genrgia, Tennessee, Florida and Mississippi

The meeting also included state and federal officials and representatives of Chem-Nuclear Systcms Inc., operators of the sitc near Barnwell, S.C., where most lọwlevel nuclear waste from the castern United States is buried.

Riley told representatives that backup sites must be designated because South Carolina cannnt serve. indefinitely as the South's nuclear waste burial ground.

"Any state that fcels that because South Carolina has a site. South Carolina is the answer to the region's problems ... is not looking at the entire situation." Riley said.
The governur said all statcs ill the region must conrribute if they decide to form a compace for handling low-level waste.

"No area is ... immune from sharing in that responsibility." Riley said. "This is a multistate effort and if everyone contribules. then no one will have a dangerous. undesirable situation."

He said the states must desig. nate a second and possibly a third site as backups for waste digposal when the Barnwell site reaches capacity.

The federal law says each state is responsible for the gafe handing and disposal of low-level waste within its boundaries. But it also allows states to entcr reginn. al agreements for handling slight. Iy radioactive materials generated by hospitals, laboralorics, nuclear power plants and other producers.

The law also gives states like. South Carolina power io forbid other states from sending wastes to burial grounds within their bor. ders.

Reid said the state representatives agreed to mect again about March i. 


\section{States To Pursue Regional Pact}

\section{By - CLARK SURRATT}

Representatives of nine southeastern states agreed Monday to pursue on a formal basis the establishment of an interstate compact to hardle burial of low-level nuclear wastè.

The Columbia meeting was arranged by Gov. Dick Riley and is the first such gathering in the nation to discuss forming compacts under an authorizing law passed by Congress last month.

David Reid, Riley's energy aide, said participants agreed $t 0$ go back to their states and secure the formal authorizations necessary to work toward a multi-state pact. Authorizing legislation by each participating state is required, along with an act of Congress. to ratify a compact.

We agreed that as soon as possible each state ought to come back in a formal way. empowered to suggest legislation. to form a compact," Reid said.

Two of the states represented Monday. Virginia and Kentucky, might not end up in a compact that would include South Carolina.

Reid said Virginia is hosting a meeting of its own to talk with some other states and that
Kentucky might ultimately be one of the states to form a compact with Virginia.

Other states represented in the Columbia meeting were Alabama. Georgia, North Carolina, Tennessee, Florida and Mississippi.

The meeting also included state and federal officials and representatives of $\mathrm{Chem}-\mathrm{Nu}$ clear Systems Inc.,. operators of the burial ground near Barnwell where most of the low. level nuclear waste from the eastern part of the nation is now buried.

Low-level nuclear wastes are those less toxic radioactive materials generated by hospitals, laboratories, industries and power plants.

\section{On Nuclear Waste}

As he has preached for months. Riley told the representatives prior to the meeting that other states shouldn't depend on South Carolina to handle all their wastes indefinitely just because this state already has an operable burial site.

"No area is, nor should any area be, immune from sharing in that responsibility," said Riley. "This is a multi-state effort, and if everyone contributes. then no one will have a dangerous, undesirable situation."

Any state that feels that just because South Carolina lias a site. South Carolina is the answer to the region's problems is not looking at the entire situation." the governor said The new federal law makes each state responsible for disposing of its low-level nuclear wastes. including a veto power effective in 1985 on importing wastes from other states. But the law also allows for multi-state agreements on disposing of wastes.

Reid said the group did not get into the prospects of forming a compact to handle chemical and other hazardous wastes.

He said the state represenatives agreed to meet again about March 1 .

"Gov. Riley will notify each state's goverwor of our decrision to procerel in a more formal mamuer," Reid said after the meeiing. 
Jan. 7. 1981

\section{9 southeastern states OK pact on nuclear waste}

COLUMBIA (AP) - Nine southeastern states have tentatively agreed to form a compact to handle disposal of low-level nuclear waste.

The ctate officials attended a meeting in Culumbla hosted by Gov. Dick Riley on Monday. They agreed to meet again about March 1.

- South Carolina currently has the only nuclear waste disposal site in the East in Barnwell. But Riley warned the other officials not to expect this state to shoulder that burden forever.

"Any state that feels that because South Carolina has a site, South Carolina is the answer to the region's problems ... is not looking at the entire situation," Riley said.

The meeting was the first in the nation to discuss forming interstate compacts under a new law passed by Congress last month.

David Reid, an aide to Riley, sald representatives of the states agreed to return to their states and scek authorizations to work toward a regional pact.

Two states, Virginia and Kentucky, might opt for another compact, he said. Virginia is holding a meeting to talk with other states and Kentucky might enter the Virginia compact, Reid said.

Other states represented at the meeting were Alabama, Georgia, North Carolina, Tennessee, Florida and Mississippi.

Federal officials and representatives of Chem-Nuclear Systems Inc., operators of the Barnwell disposal site, also attended the meeting.

Riley said that all states in the region must partcipate if they decide to form a compact. "No area is ... immune from sharing in that responslbllity." Riley said. "This is a multi-state effort and if everyone contributes, then no one will have a dangerous, undesirable situation." 
Jan. 8, 1981

\section{Nuclear waste discussed}

COLUMBIA-Representatives of nine Southeastern states agreed Monday to pursue on a formal basis the establishment of an interstate compact to handle burial of low-level nuclear waste.

The Columbia meeting was arranged by Gov. Richard Riley and is the first such meeting in the nation to discuss forming compacts under an authorizing law passed by Congress last month. David Reid, Riley's energy aide, said participants agreed to go back to their states and secure formal authorization necessary to work toward a multi-state pact.

Also sitting in at the meeting wert representatives from the S.C. Department of Health and Environmental Control and ChemNuclear Inc., which operates the only low-level nuclear waste storage facility east of the Mississippi River.

As he has preached for several months, Gov. Riley told the representatives prior to the meeting that other states shouldn't depend on South Carolina to handle all their wastes indefinitely Just because this state has an operable burial site. 


\section{The Nuclear Waste ED:Daiu}

New ideas, policies and perspectives are anticipated in the area of energy planning with the new Reagan administration coming on board.

Former S.C. Gov. James B. Edwards, selected by Reagan to head the U.S. Department of Energy, has taken a strong stand in favor of nuclear power, as. has Reagan.

Most of those knowledgeable in that field are in agreement that the major problem with regards to nuclear power is not the danger from the power plants as much as from disposal of their radioactive wastes.

U.S. Sen. Ernest F. Hollings, RS.C., recently said what is needed out of the federal government is a decision on permanent storage. Then planning can move into the areas of solidification and removal of temporary stored waste in South Carolina to its permanent spot.

Other than that, nuclear energy is safe and it's needed, especially if we are going to continue to compete in this world from an industrial standpoint, Hollings said.

We agree with Hollings, and we hope that under the new adininlstration and the leadershio of former Gov. Edwards, this type planning will finally be accomplished.

Nuclear energy and nuclear waste became an especially heated issue while President Carter was in office. As the issue grew political in its orientation and consequences, planning and decision-making regarding permanent disposal of nuclear wastes all but ground to a halt.

Meanwhile the wastes continued to stockpile, wuch of it in South Carolina.

S.C. Gov. Dick Riley and others have taken a strong stand against the rest of the nation using this state as a nuclear dumping ground, especially as long as there are no plans for taking care of the waste in permanent way.

Already steps are being taken to improve the situation, and announcements have been made that nuclear reprocessing will probably be allowed at the facility near Barnwell.

We urge continued planning and action to take care of the nuclear waste problem. Political consequences have been the determining factor in that issue for far too long. 


\section{Conservation}

\section{Award Winners}

\section{Named}

ine South Carolina Wildlife Federation has selected Governor Richard Riley as its 1980 Conservationist of the Year in recognition of his leadership in nuclear. waste management.

"Governor Riley has been, in many cases, a lone voice in a long campaign to secure from Congress a sensible, comprehensive national policy for handling and disposal of low and high level nuclear waste and also hazardous industrial waste," said Federation President .A. Mitchell Godwin of Conway in making the announcement. "Because of his efforts, the nation is recognizing the dimensions of the problem and is working towards a solution."

Other award winners selected for recognition were John Evans of Columbia, Communicutions; Brice Lathan of Sandy Springs, Education: Herman Hermelink of Charlotte, $\mathbf{N}$. C., Forest; Charlie Snider of Anderson, Hunter Safety; S. C. Electric and Gas, Hydro and Environmental Engineering, Industrial; Elizabeth Lever of Columbia, Land; Ecological Services Office, Region 4, U. S. Fish and Wildlife Service at Charleston, Organization; Hubert E. Yarborough of Greenville, Water; Dr. James A. Timmerman, Jr. of Columbla, Wildlife; Heather Meeds of Summerville, Youth; Nancy D. Cathcart of Hilton Head, special posthumous award. Anne Worsham Richardson of Charleston, spectal award.
The South Carolina Wildlife Federation's award program recognizes individuals and groups for outstanding conservation efforts. Presentations will be made at the Federation's Conservation Achievement award banquet Feb. 28, 1981 at the Myrtle Beach Sheraton.- 


\section{Smith says delegation alert to nuclear dumping dangers}
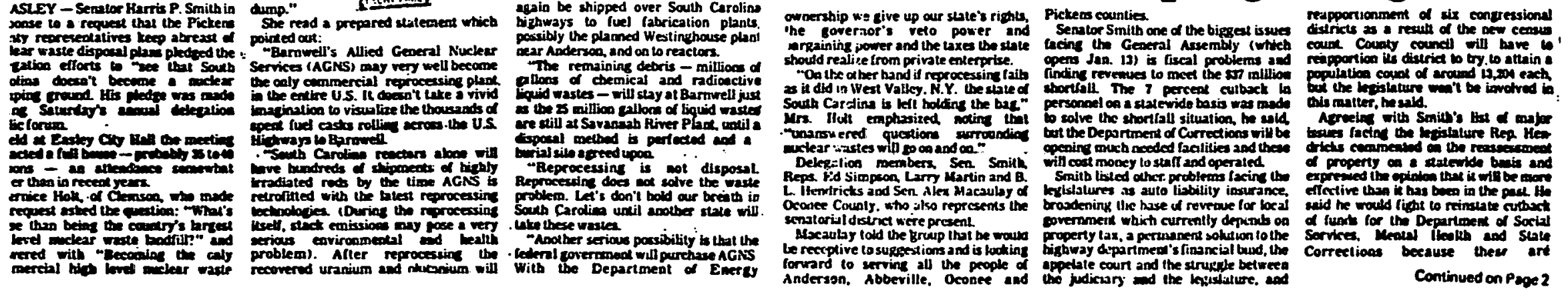

serves needed in a time of declining will need personset to staflions ad thisitive will mean more finances, he said.

Rep. Simpeo moted trat ibe state has

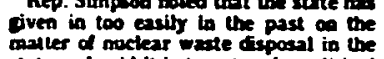

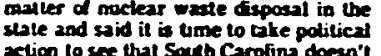
tecome a nalional durmpine eround Simpsion sus chat he stit topes to get a have them reoort conseng and raw malerials and a ner macrease in jobs. He said be would support a
poposed change in the driving age from .

Rep. Alaria said be agreed with the other members that scome doparumemts mo greal hardship and that edjesermeats thich render a vitul publice setvirel like

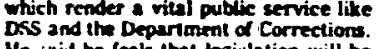
Ite said he forls that kepistation will be indrulued to increase the sules lax from prestaled on auto issurgese. Martin said driving records.

Durne the question-answer period lault it is that the state ill of a whose Rep. Hendricts exphained int when the state lock over beal prisoners the step et? measures were laten through Sen Smith said that mang menes are said hal many depar menpriatives that the tor barker doest ap whal likey need as wat the case with the

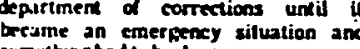
sumethung had tube dans

atsflin hept hammering away with questions: Why was the library

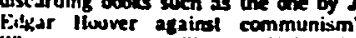
Why dre so many Chemson University
surs seen un the highway with just une

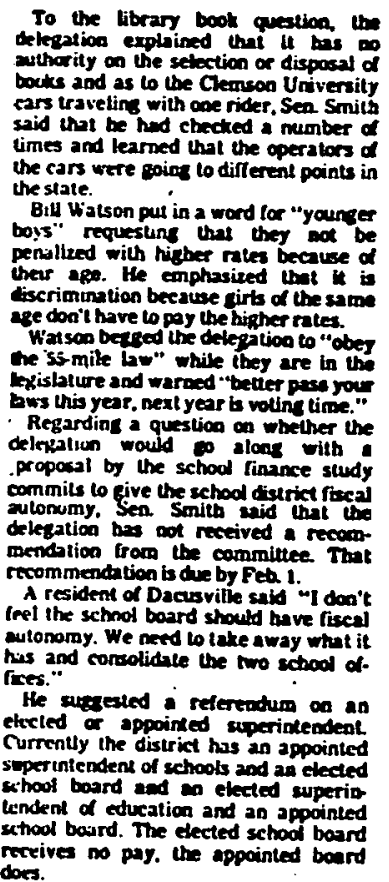


THE NEWS, Greenville, S.C.

Jan. 21, 1981

\section{Safe disposal \\ first priority}

\section{By PHYLLIS M. JOHNSON}

Ri. 10

Radioactive garbage has been piling up in the United States for over 35 years.

Thirts'three years ago, according to a retired Navy pilot, atomic u'astes were dumped in the Atlantic. and the missions litter erased from Navy llight logs. Tnday we still have no national plan for the disposal of high-level wastes, and no consensus on what constitutes safe disposal.

Meunwhile 25 million gallons of high-lcvel wastes are accumulating in temporary storage tanks at the federal nuclear weapons fuel plant on the Savannah River. Yet, this - ncuspaper calls for activating the nuclcar fuel reprocessing plant at Bamuell. Only second does The Greenville News turn to the problem of high-level waste management.

Reprocessing extraces uranium and plutonium from spent fuel; it does not significantly reduce the amount of high-lcucl waste from spent fucl. If Barnwell is opened as a reprocessing plant, South Carolina, would receive a backlog of used reactor fuel from all over the country.

Tha high-level wastes remaining after reprocessine wnuld be stored at Barnwell until a permanent burial site is opened. Such a site will probably not be opened until at least the mid-1930s.

Some of the "low-level" wastes South Carolina already stores are highly radioactive and hazardous. Low-level wastes are classified by their source not their degree of radioactivity.

It is time to come to a sereeching halt. Only when the riddle of safe. nermanent nuclear waste dispnsal has been solved, should reprocessing be considered. South Carolina atrendy shoulders too heavy a waste burden as the result of a splintered nuclear waste policy. 


\section{States To Pursue Regional Pact On Nuclear Waste}

D. CLARK SIRRAT

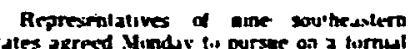

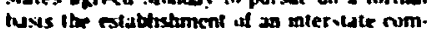

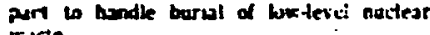

The rolunitha meturg was arronzed oy

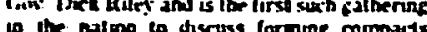

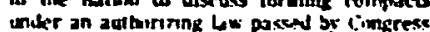
id 1 minis

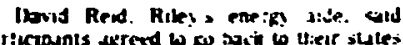

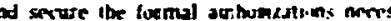

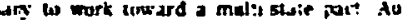

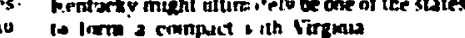
diset is required. aloog ath on oft if Cin r. We rathy a marpuri

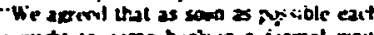
compuct." Rerd said.

Two of the water rexesented Monday.

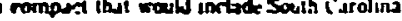

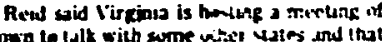

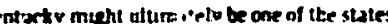
(xher stales reptin inted in the cilurabia Ina. Teapessen Fle de and Hissusspopt.

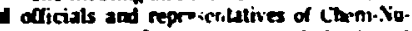
dear Systerms Ine.. parestors of tor bunal

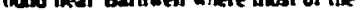
vet asciear wate timl he easters part of low-levet naclear azitos.

Co

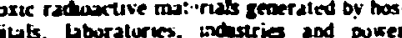
Panss. ine metion also:antisted rate and teder.

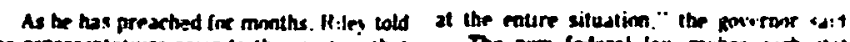

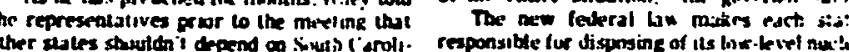
ar astes. including a vero power effertive.

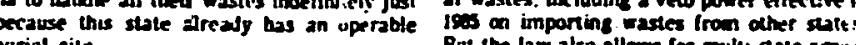
Rut the ba also allows for multh.sale agrem

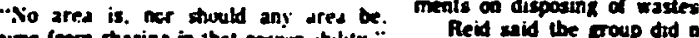

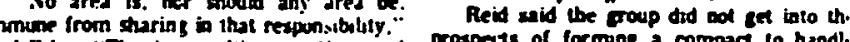

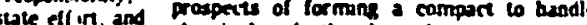

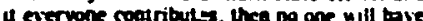
a dangerous. undestizable situation

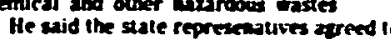
mier again about March 1.

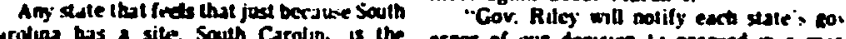

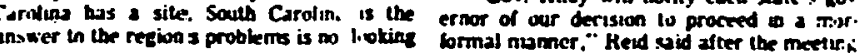


Jan. 2, 1981

\section{PRESIDENT SIGNS NUCLEAR WASTE BILL, GENERAL REVENUE SHARING EXTENSION}

President Carter has signed into law bills that clear the way for states to develop a solution for the disposal of low-level radioactive wastes and that extend the general revenue sharing program through fiscal 1983.

Enactment of the nuclear waste disposal bill, which is based largely on recommendations from the nation's governors, will enable states to provide for the safe disposal of low-level radioactive wastes generated through such activities as scientific research and medical procedures, according to Arizona Gov. Bruce Babbitt.

Babbitt said that radiological research and medicine nearly came to a halt in 1979 when the governors of Nevada, South Carolina and Washington restricted access to the nation's only commercial low-level waste disposal sites. The governors' actions followed the consistent failure of waste generators to properly package and transport their wastes and the subsequent failure of several federal agencies to adequately enforce waste packaging and transportation regulations and impose proper sanctions. Also at issue was the unwillingness of the three states to continue to serve as the only disposal sites for the rest of the nation.

To address those problems and come up with a plan for dealing with the expected increase in the volume of medical, scientific and defense-related low-level. waste (the nation is expected to generate 321,000 cubic meters of low-level waste by 1990, compared with 99,000 cubic meters in 1980), the National Governors' Association created a task force, chaired by Babbitt, to study the problem and suggest solutions.
Babbitt said the bill signed by the president "includes the major recommendations of our task force--that each state be responsible for the wastes generated within its borders, that regional compacts among states offer the most promise for an equitable solution, and that these regional groupings be allowed to exclude wastes generated from outside the region." Authority to exclude waste generated from other states inust be granted by Congress because of the constitutional prohibition on interference in interstate commerce. 
Andy Plattner is a writer for Congressional Quarterly, a non-partisan news research service.

WASHINGTON - Congress has decided to give the states the re sponsibility for burying low-level radioactive trash. But it adjourned without deciding what to do about high-level nuclear waste or the mounting quantities of radioactive spent fuel burned by the nation's nuclear reactors.

Although radioactive garbage has been piling up in the United States for over 35 years, Congress had never developed a national policy for dealing with it. When it did finally pass its first nuclear waste bill in the last days of the recent session, it dealt with only one part of the problen - contaminated trash from hos. pitals, industiles and power plants that use radinartive materials

Efforts to pass a more comprehensive bill fell apart because key senators could. not agree on how much say state governments should have - if any - over the burial of military waste within their borders.

Low-level wastes include radia. tion-contaminated paper, plastics, construction materials, tools, protective clothing, vials, solutions and industrial waste. They are generated in every state.

Some experts object to the term "low-level." saying it erroneously implies that these wastes' are not dangerous, when in fact, some are highly radioactive and hazardous. The classification is not based on the degree of radioactivity, but the source. Basically, all radioactive waste not produced in nuclear reactors or in the reprocessing of nuclear tuel is considered low-level.".

Under the bill that was passed, each state will be forced to deal with the problem of burying low-level wastes. States can build their own dumps or form regional compacts to establish mutual sttes, the option most are expected to choose.

After 1985, regional groups will be permitted to exclude waste from states that don't join the compact.
The federal government will continue to bury its own considerable production of nuclear garbage. The regional compacts could not make policies affecting federal waste, which comes mostly from making acomic weapone

The only states with dumps where low-level. nuclear waste can be buried now are Washington, Nevada and South Carolina, and they're getting tired of accepting the entire nation's outout.

Washington residents voted Nov. 4 to close the disposal site at hanford to out-ol-state nuclear garbage starting next summer. The governor of Nevada has vowed to close that state's dump at Beatty. And South Carolina Gov. Richard W. Riley, whose state accepts the bulk of the nation's radioactive trash, has said it will arcent lass of it in the future.

Nuclear waste legislation ap. peared dead in the waning days of the S6th Congress; until Riley's office let it be known that the gover. nor was considering closing the Barnwell, 8.C., tump to out-ol-state waste if Congress did not pass at least the low.level portion of the bill.

Riley's ally in Congress, Rep. But. ler Derrick, D-S.C., put together an unusually forceful effort to secure passage of the low-level waste provisions in the midst of Congress' end. of-session debate.

Derrick camped on or just off the Senate floor for more than nine - hours on a Saturday, grabbing key senators, persuading them that the low-level portion of the bill was needed. The Senate passed it that aftemoon, and the House followed suit a few hours later. Without Derrick's persistence the measure would not have been passed, according to others who were involved.

Derrick said senators were "a litthe startled" at seeing a member of the House on the vrong side of the Capitol, but "that's where they were, so that's where I went"

The legislation was supported by medical groups and state govern:ment organizations. W'ithout it, the
National Governors Association warned, the low-level waste problem could rapidly lead to a crisis situation affecting almost every community in the United States.

While the nuclear industry, the utility lobby and the Carter adminis. tration were not unhappy to see the enactment of the low-level waste bill, they were disappointed with Congress' failure to set a national policy for the disposal of high-level wastes and soent nuclear fuel.

A bill passed by the Senate in July called for temporary storage of highly radioactive waste in monitored vaults near the earth's surface. It also provided for federal storage of spent fuel from commercial nuclear reactors.

In early December, the House passed a much different bill. It called for permanent waste storage repositories in natural rock forma. tions, which environmental groups said whuid be safer than temporary vaults. And it did not provide for federal storage of spent fuel; which environmentalists attacked as a bail. out of the nuclear. industry.

Following passage of the House bill, repeated clforts were made to find a compromise, but the issue of state power over military nuclear waste proved irreconcilable.

sen. Henry M. Jackson, D-Wash., chairman of the Senate Energy Committee and a powerful member of the Senate Armed Services Com. mittee, demanded that the legislation specificially exclude military nuclear waste facilities. Jackson wanted the states prohibited from raising objections 10 military waste sites within their borders.

However, Sen. - John - Glenn. D.Ohio, insisted on giving tha states the right to oppose any nuclear waste site, military or civilian, subject to congressional review.

More than half of all radioactive waste has been generated by the military, Glenn said, and "we just can't sweep it under the rug. It is just as much a hazard to the public" as commercial niaste 
Dec. 16,1980

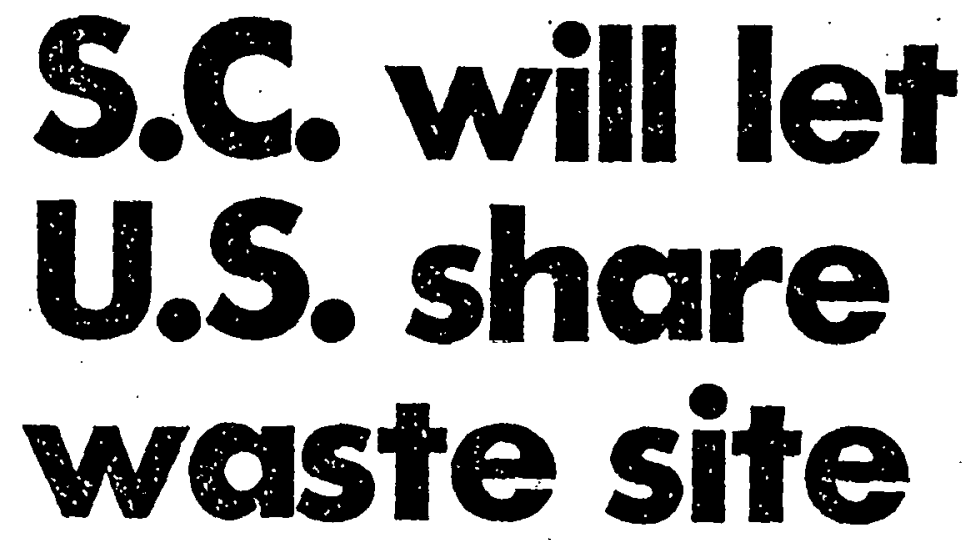

COLUMBIA, S.C. (AP) - The U.S. Department of Defense has become the first and only federal agency authorized to send its lowlevel radioactive wastes to the Chem-Nuclcar Systems Inc. dump in Barnwell, S.C.

Gov. Dick Riley announced Monday that an agreement was reached between the Pentagon and the state of South Carolina to allow the Defense Dopartment to send slightly radioactive wastes to the Barnwell dump.

In the past the only Defense De. partment wastes allowed into South Carolina went to the Savan. nah River Plant, a privately operated Department of Energy facillty, also near Barnwell.

The Chem-Nuclear disposal site. located on state land, is the only dump on the East Coast licensed to accept low-level wastes. It is one of just three such dumps in the nation. The others are in Ne. vada and Washington state.
Riley, in a statement, sald the agreement with the Pentagon was similar to one negotiated two months ago with DOE. Both agreements for the first time re. quire the federal agencies to give state officials advance notice of their plans to ship and store wastes.

The governor sald the agreement with the Pentagon was reached voluntarily in order to avoid a possible legal conflict over a 1980 state law regulating radio. active waste transportation and disposal.

Riley said the basic difference betwcen the agreement and the new siate law is that the Department of Defense will not need a state permit for waste transporta. tion.

However, the state may take "reasonable corrective action, including suspension or revocation of disposal privileges." 


\section{Defense department agrees to give advance warning of nuclear waste shipments}

\section{By The Assoclated Pras}

COL.UMUIA - The U.S. Department of Defense has become the first and only federal agency authorized to send its low. level radioactive wastes to the ChemNuclear Systems Inc. dump in Barnwell.

Gov. Dick Riley announced Monday that ai) agreement was reached betwcen the l'entagon and the state of South Carolina I0 allow the Defense Department to send slightly radioactive wastes to the Barnwell dump.

In the past the only Defense Department wasles allowed into South Carolina went to the Savaniah River Plant, a privately nperated I)epartment of Energy tacility. alsi near Barnwell.

The Chem-Nuclear disposal sile. located on state land, is the only dump on the East ('vast licensed to accept low-level wastes. It is one of just three such dumps in the naliun. The others are in Nevada and Washington state.

Hiley. in a statument. suid the agreeinent with the Pentagon was similar to one negotiated two months ago with DOE. Both agreements for the first time require the federal agencies to give state officials advance notice of their plans to shlp and store wastes.

The governor said the agreement with the Hentagon was reached voluntarily in urder to avoid a possible legal conflict over ¿ 19\%0 state law regulating radioactive waste transportation and disposal.

The law requires that anyone who plans to ship or dispose of nuclear wastes in Suuth Carolina first receive Iransportation and dispusal permits Irom the state and alsu give state health officials advance nutlce of planned shipments.

Ilowever. Iederal officlals questioned whether a slate law could constifutionally te applied to federal shipments. That question led to the voluntary agreements I we months ago with DOE and this month with the Pentagon.

liticy said the basic difference between the afreoment and the new state law is Ifat under the agreement the Department of IDefense will not need a state permit for wasle transportation.

llowever. the agrcement says that if the department violates packaging and transport regulations, the state may take "reasonable corrective action, including the suspension or revocation of disposal privileges " lor the Chem-Nuclear site.

The Defense Department has agreed to let the stale Depurtment of Health and Environmental Control know in advance of its plans to ship wastes to the Chem-Nuclear
The agreement says that if the department violates packaging and transport regulations, the state may take 'reasonable corrective action, including the suspension or revocation of disposal privileges' for the Chem-Nuclear site. Wastes 'under escort for the purpose of national security or defense' will not be covered by the agreement.

site or the Savannah River Plant

Shipments to the Savannah Kiver Plant will not be significantly affected by the agreement. All it say's is that if a serious or recurring irregularily in packalging or luading is found at Stht', the govermor "Inaty then notify the Uniler Secretary of Energy who will review the matter and ad. vise him."

Defense Deparinient wastes "under escort for the purpose of national security or defense" will not be covered by tie agreement.

The principles were negetialed by Riley atde Elliott $D$. 'Thompson and Defense Department ofticials. James P. Wade Jr., assistant to the secretary of defense for alomic energy, in a letter to Riley noted that Thompson "has negutinted with our staff to resolve the complex isstie's sur. rounding the transportation aud disposal problen. I ain pleased with the sulution we have reached."

lliley returned a sigued copy of the principles ln winde with a covor lotter noting that no consideration was given to awayfrom-reactor storage of spent tuel, cummercial reprocessing or high-level waste shipments in South Carolina

The governur said in the letter he was "extromely pleased" with the agrcement.

In his statement Riley said, "I continue to be concerned with protection of the public health and salety in malters of this nalure and believe the Department of Defense, through this agrecinent, has recognized its responsibilities for the safe Iransportation of nuclear waste." 


\section{Frantic Push Frantic Push Of Waste Bill Of Waste Bill Is Successful Is Successful}

\section{Laso Could Reduce}

Dumping In S.C.

D RODERT HODLERT

WASHINGTON - Peced with what ceemed to be imoinent summent. congre papid ou stlurday that could end soven can olimplas iround for bowilevel ons clear wate.

The bill passed the Senute on ca unrecorded voice vote after only 20 minutes of debate. It took ovoin less sime to pase unenimoudy in the House.

in public. It all looked easy. Bur The bellind the-semes ceton leadins to passage was irenetle. A limen. Rep. But lep Dertick o malor pusher. sprintes back and lorih from the serste to the tomished tountsis As late as Thureday alter. key eupporters Derrtel It resurrection provides cllmpes Into how the lofialative proces really works - and It's not exactly the edoy a.

ollores in tivics books. Currently, only three stres in
the nation store mildy redioneture wastes - in wathingeon state wastes - In Wathingeton State. Earnwell alle gets 75 parcent of the wate.

The bifi pasiod saturday woute

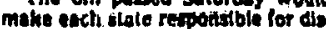
posing of lie own bow-lovet mine seltus wate and syse artes me enter Into agreements wilh nelph. borting alates to create dumpe.

Por South Caroline, the prattical elfect la that li will now only hive to sceept waste from stales
in the Southeast. es opposed to rates all over the country.

Derrek sold the meaxuse wa imporrane because the radrecllive naterin is "toxle it's burtes in ur state, they're jus pilling it up ad ollini if up. Who knowe what could have happened?

All year. Consrest has wrestie with the problem of nurlear

\section{Coatlamed tron Page ic}

ective wasteand the more contro

verdai migh-invel radioactive waste. which indudes spent fuel irom resclors.

The sernate and Houser howerrs. coultint igres on idll dealing with both tinds of wasth. Sen. Ilony Jackcon. DWah. chairman of the couree Completere provides Re mavor stumbiling block.

- Orieinally, bols kinds of nucle. ar weste were to be covered by one blll. and one of the most can. Irovertial sections of that nill would huve allowed states come veto power over the creation of a high-level wante atorage alte. Jackion. stroas backer of the Pentogon. didn't want to allow states io prosisn the storige of dele irom the wuelest - Trllov. dustry - within their bound inHy lase Thursday it appeared no cnmpromise could be lound that would satisfy Jackson.

Bui late Thursday afternoon. Derrick decided to see if a bill dealing with only tho less controversial low-level wasto could be passed.

Nerrlek spoke to Rep. Morrls Udall. DAAri.. ehalmen of the House intertor Commities. and kep. Charles Oingell. Q.Mich. and Pnwer subcommittee, whose approval is exeentlas for ony weste le tistation.

Udall had no penblem with Der. rick's proposal, but Dingell. be inte he gave up on the sompre hensive bill. wanted to be sure II was thopeless ellort.

White Oingell tried to contact Jurkson. Derrick wat llains up help Iram scuth Carouna's sen mond and Democrat Erneet 110 . lines. who would be nemict to light int the will in ine senate.

- Al 3:J0 p.m. Hirddas. Dinzell called Derelck wilh had news. Jackeon would nill sllow any nemete disposal bill to come un even the low-level hill. Dingel would allow states to bat miliury nuclear wante.

Dut Dertick. propoet apect. lcally excluded milinery wate. "I could the mily waste. Dlneell relessed me." Derrict sald. "When he thought the crom prenentive) Ull! wos opad, he
A Derrick alde recalled. "He stood up. erabbed the nill and Dorrick and Mollinge reached Jeckeon by phone friday night and persuaded him the low-level bll would not harm the milltary. Jeckson withdrew his objex-

Saturday morning. shortly after midnight, Derrick was awakened Dingell. by a phone call Irom that Derrick had been able to win over Jockson. "You must have come son of mirecle power." Dingell told him.

By now.. however, Congress was nearting adjournment. And 1 turned out on unexpected number of senalors oppnsed Derrick's bill, apparcntly confusing it with the controversich bill dealing with the iriday night and saturda

tek rick spent more time roaming hunting for senetor to mer - than on the House side.

Shortiy altrs 1 p.m. Saturday. Derrick had found each of the hall-dozen senutors who hed pul "hold" on the bill. Normalty, such a hald ean only stop ection on bill for several daye and isn't fala 10 bill. But with only hours re. temporary hold could have killed the bill.

The only remalnian sentfican The only remaining dentifican legisiation befpre Conerros wal the House and Senule agreed upon that bill. Constess woula be over. gy 4 P.m. Salurdey. The House hed linishid its work on the spending bill and sent 11 to the Senale. Me 1:20 R.m. to the Senale, Sen. James MicClure, R.Idinh, Who will chair the Senale Energy Derrick's bill.

Twenty minutes later on voice vine the bill pased the sanate.

Derrick, who had benen sitting treslde Thurmond In the chamber, dashed lit thr llouse chamber to
inform l'dall, on the bill could ho inform l'dall, in the bill

introctucid in ine liwuse. It tonk I rewtick three more erlps
back to the Senate befose he could ant an nflielal. slened copy of the bili delivered 10 the llouce. The bill was delivered at 7 p.m. and with only the mont perfunctory debate. It was patses by "unatimemibers present objected.

Derrick was rushing to avold what all wought was the immlunday evening coneres over the quest consreg stalled year pay nite Senate decious io year pay Meanwhlle morning. rick returned to his olliee wher he shared botlles of champante with hie scafs.

While many of his fellow legis. Ialon wern prassing Dertek, none was mors effustre than the ubually grulf bingell, who had whiten of any chance of pasding the wll. "But for this guy, you tolke woulant be chis this seas." 
Dec. 11, 1980

\section{S.C. may bar nuclear waste till issue settled}

COLUMiBIA, S.C. (AP) - Gov. wilh a waste disposal bill since Dlck Rlloy may bar all low-level last week but has been unable to

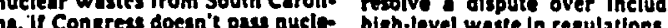
ar waste storage resulations.

Last year, Riley clamped down on the amount of low-level radlo ind member of the conterence active waste that could be committee, has been trytng 10 get broughe in but a dump operated the questions of high-level and by Chem Nuclear Services Inc. low-level disposal separated so near Barnwell still gets about halt the low-level portlon minht pash

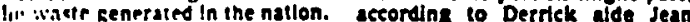
There is no oinc: storage facili. Iy on the East Coast.

A Housi-Senate conterence Rilty hat been in trequent con. Rite has been in frequent con. committee has beed wrestilins
South Carolina with the country's action now to create the desper only major sile for low.level nu. ately needed additional disposal clear waste disposal by next year capecity in this country" "memo and the oovernor endn haiting all out-ol-state ship ments. Alternatives the covernor has lina may back away from its declIn case Congress tuils to aet. In. sion to sllow entry of any state clude lurther curbacks but nos a waste in limited amounts and rocomplate abolition on radloactive materla This would put the added York. New Jersey, Pennsylvanis. The memo also sald South CaroSoutheastern states only. Congressional sources wy the from reactors and other sources in

adioaclive material. Some seno atore don't want the potnt oven mentloned in the bill, which as passed by the Houce would set pess deadline for federal selection

All tacitons azree. according to Derrick, thst states should be ible or disposal of low-level wast wP. :h is considered hish-level gowns o get together to select a locatio 年 
Dec. 11, 1980

\section{S.C. may bar nuclear}

COLUMBIA, S.C. (AP) - Gov. Dick Riley may bar all low-level nuclear wastes from South Carollna, if Congress doesn't pass nuclear waste storage regulations.

Last year, Riley clamped down on the amount of low-level radioactive waste that could be brought in, but a dump operated by Chem Nuclear Services Inc. near Barnwell still gets about hall -lir waste generated in the nation.

There is no othe: storage facillty on the East Coast.

A House-Senate conference committee has been wrestling with a waste disposal bill since last week but has been unable to resolve a dispute over including high-level waste in regulations.

Rep. Butler C. Derrick, D.S.C., co-sponsor of the House version and a member of the conference committee, has been trying to get the questions of high-level and low-level disposal separated so the low-level portion might pass, according to Derrick aide Jean Neal.

Riley has been in trequent con.

tact with Derrick, Ms. Neal said.

Riley's advisers have said con-

\section{waste till issue settled}

gresslonal Inaction would leave South Carolina with the country's only major site for low.level nu. clear waste disposal by next year and the governor might consider again halting all out-of-state shipments.

Alternatives the governor has, in case Congress fails to act, in. clude further cutbacks but not a complete abolition on radioactive material allowed from other states.

"This would put the added pressure on other states like New York, New Jersey, Pennsylvanla,
Ohio and IIllinols to take positive actions now to create the desperately needed additional disposal capacity in this country." a memo from his staff said.

The memo also said South Carolina may back away from its decislon to allow entry of any state's waste in limited amounts and restrict storage to material from Southeastern states only.

Congressional sources say the stalemate is over what to say about storage of military waste. wr.: is is considered high-level radioactive material. Some senators don't want the point even mentioned in the bill, which is passed by the House would set a 1985 deadline for federal selecticn of two permanent disposal sites.

All factions agree, according to Derrick, that states should be able to get together to select a location for disposal of low-level waste from reactors and other sources in their borders, including such. things as slightly radioactive gowns from hospitals and laboratories. 
Dec. 12,1980
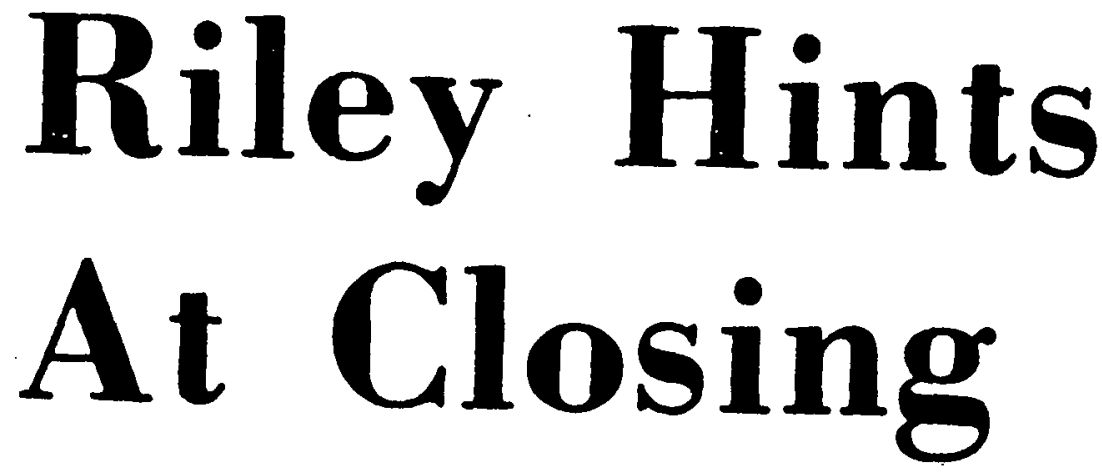

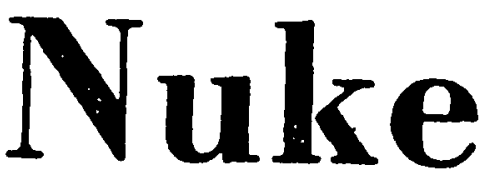

Gov. Dick Riley's staff, trying to send a strong signal to Washington. has mentioned in writing the prospect of closing the Chem Nuclear Systems site to low-level waste from other states.

The governor is not close to taking that action, a spokesman said, but is putting the option up for discussion to try to get Congress to pass a law calling for regional burial sites for low-level waste.

AS IT HAS for some time, the burial ground near Barnwell lakes more of the nation's waste than any other location. Riley has been on a campaign for months to get other areas of the country to bury their fair share.

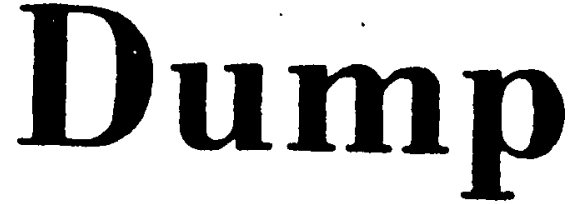

Prospects for the regional burial legislation do not look good for now, said Rep. Butler C. Derrick, D-S.C. sponsor of the bill. He has been pushing a compromise bill that also deals with several other nuclear issues.

He said if a House-Senate conference committee fails to agree on legislation, then he'll introduce the bill in the next session of Congress, though admitting it could be another five to six mnnths bofore it paoses.

AMONG OTHER STEPS, Riley aides suggested the govemor consider keeping other states low-level nuclear wastes from beiing shipped to

\section{Riley Hints At Closing Dump}

\section{(Continued From 1-D)}

Barnwell, the only such site in the east.

A year ago Kiley sharply reduced the amount of low-level material that could be brought to the facility, but the site still gets about half that produced in the nation.

There are two storage sites in the west. in Nevada and Washington, which could be closed within months. Washington voters said in November that without federal legislation making other states responsible for their waste, its site should be closed.

Nevada's waste vite is projected to be full in 1982.
Derrick said he would not favor a total ban on out-of-state waste but would support a further reduction ia the amount permitted, another option suggested by Riley staffers.

A staff memorandum to the govemor this week suggested that a complete ban "may be just what is needed to get the "mule's' attention" - "the triggering mechanism" to get all states to accept responsibility for their own waste would be for states or groups of states to be able to exclude waste shipments.

The memo also said South Carolina could beck away from its decision.to allow entry of any state's waste in limited amounts and restrict storage to material from southeastern states only.

All factions agree, according to Derrick, that states should be able to get together to select a location for disposal of low-level waste.

The House approved legislation: last weck that calls for the creaticn of interstate pacts to shift the respon. sibility from the three states to a regional basis.

One of the primary obstacles to agreement came from Sen. Henry Jackson, D-Washington, who did not want to grant states the power to reject their selection sites for wasive generated from military arms production, said Derrick. 


\section{House Votes Designated Permanent $N$-Waste Sites}

\begin{abstract}
By LEE BANDY
Hashlaztea Bureser

WASHINGTON - The House adopted legislation Wednesday to start designating permanent waste sites for disposal of highlevel nuclear wastes and to estab. lish a regional burial program for low-level material.

The measure. adopled by voice vote. was immediately sent to a conference with the Senate. which has approved a drastically different version including a $\$ 300$ million program for away-fromreactor spent fuel storage facilities.

Rep. Buller C. Derrick, DS.C.. author of the low-level provision in the House bill and a conferee, said he is confident Congress will have the legislation on President Carter's desk before ad-
\end{abstract}

journing Friday.

The low-level amendment was developed by Durrick in cooperation with Gov. Dick Riley. It specifically gives states authority to enter into regional compacts for the burial of low-level waste.

"This should lead to the crea. tion of six or seven sites throughout the nation." Derrick told the House. "The sites would handle waste generaled within a regior. No one area of the country wouid bear the entire burden. The waste would remain within a limited area and not be transported across the nation."

Presently, there are only three low-level waste sites operating in the nation. in South Caroli-

(See HOUSE, 17.A, Col. 3)

\section{House OKs N-Waste Storage}

(Continued From 1-A) na. Nevada and Washington. They handle such con. taminated items as clothing. medical supplies used in nuclear medicine, tools and other materials from nuclear research laboratories.

The Chem Nuclear buria! site near Barnwell receives the bulk of the contaminated material east of the Mississippi.

"Unless we provide lead. ership to solve the waste disposal problem." Derrick said. "we are quickly going to find this country without disposal sites for waste now being generated, much less for the future."

The Edgefield Democrat Inbbied long and hard for the House bill. He had Riley calling state officials around the nation urging them to contact their congressional representatives.

Derrick said he Worked with two committee chairmen, Rep. Morris $K$.
Udall. D-Ariz.. of Interior houses to override a veto. and John Dingell, D.Mich., of the House energy subcommittee, to "pull every maneuver we could to get a solution to this politically sensitive issue."

Aside from the low-level provision, the House bill sets up a permanent repository for high-level waste by 1987.

"For 35 years, our country has been producing nuclear waste. yel we have yet to provide for the disposal of a single pound." Udall said.

"It's time we get on that joh. What we can do in these next two or three days is make a beginning on some kind of sensible permanent waste disposal procedure."

Stales can veto a site within their borders under the House bill, but one chamber of Congress can override it.

Rep. Peter Kostmayer. D.P'a.. attempted unsuccessfully to strengthen the state role by requiring both
Opponents of that approach warned that the country would end up without any permanent disposal program because states, for political reasons would be forced to say "no" to burial sites. Ohio. called Kostmayer's amendment "an anti-nuclear wolf in sheep's clothing."

Derrick said later, in an interview. that he presently opposes an away-from-reactor storage program. He indicated that he would prefer to see utilities expand their on-site storage facilities at their nuclear power reactors and the nation move to reprocessing of spent luel rods.

In endorsing a temporary spent fuel storage program. the Senate noted that several utilities had reached their on-site storage capacity and structurally cannol expand present facilities.
Rep. Clarence Brown, $R$ -
Such power companies. it sald. would need an aliay. from-reactor storage capaeity by 1983.

The Senate also noted that temporary storage makes spent fuel accessible for later reprocessing. a technology envirormen. talists are attempting to block.

Reprocessing proúuces plutonium which can be used in the manufacture of nucle. ar weapons 
Dec. 4, 1980

\section{Nuclear waste bill}

\section{gets House approval}

\section{BY CHRIS WESTON}

\section{News Statf Writer}

The U.S. House of Representatives approved legislation Wednesday designed to end South Carolina's role as the nation's chief storage site for low. level nuclear waste.

The bill, written and shepherded through the chamber by 3rd District U.S. Rep. Bucler Derrick, now will go to a House-Senate conference commitlee which will work out differences between the House bill and a bill approved earlier by the Senate.

Derrick, however, said Wednesday's action by the House almost ensured pas. sage of the low-level waste provisions this year.

"It looks good. I'm not going to be modest about it, we worked awful hard on it," said Derrick late Wednesday.

The bill approved by the House calls for the creation of interstate pacts 10 shift the responsibility for the handling of low-level waste to a regional basis from the current policy of only three states - South Carolina, Nevada and Washington - burying all of the nation's waste.

The bill would require that each state take responsibility for the waste gener. ated within its borders. South Carolina now receives most of the nalion's low. level nuclear waste at a site near Barn. well operated by Chem-Nuclear Services Inc.

The compromise legislation approved by the House also would set a timetable for the adoption of a method to perma. nently bury the nation's more dangerous high-level nuclear waste.

The bill calls for the federal Depart ment of Energy to present two sites by 1982 as candidates for a federal high. level waste repository. A final selection.

'It looks good. I'm not going to be modest about it, we worked awful hard on it.' - Rep. Butler Derrick

under the guidelines of the House bill. would have to be made by 1985 .

Derrick's bill was thought to be dead for the year because it had been altached to a more controversial nuclear waste legislative package authored by Rep. Morris Udall, D-Arizona.

Congressional sentiment for the Derrick low-level waste provisions was high after the issue was forced upon Congress last year by Gov. Dick Riley. Washington Guv. Dixy Lee Ray and Nevada Gov. Bob List, who all wanted legislation to shift primary burial emphasis away from their states.

The legislation was written by Der. rick along the reglunal responsibility lines voiced by Riley. who is chairman of a presidential commission on nuclear waste.

The initial Udall measure addressed a wide variety of controversial nuclear waste topics, including liability insurance for nuclear reactors and more strin.

(See Nuclear, p. 6-A) gent mandates in arrive at a national policy for permanently storing high-level waste.

In the waning manths of the $1980 \mathrm{con}$ gressimal session. Derrick had kept the pickinge which included his bill -stalled in the bouse Rules Commillee brcause it included a provision to create temporary awas'from-reactor storage sites for highlevel waste.

Derrick said that he blocked that bill because he believed that with the ap. proval of alvay-from-reacinr storage that much of the nation's high-level waste wnuld he shipped to the now dormant Burnwell reprocessing facility owned by Allied General Nuclear Services.

Derrick contended that he was not prepared to swap sinuth Carnlina's role. as the nation's nrimary dump for low. level waste for a chief role in storing high-level wisste.

Low-level wiste is primarily the material used in the liandling of radinactive gorads, such as gloves and tools. It has a considerably Inwer Invel of radinactivity than high-level waste and needs lar lewer storage prexalltions.

Last weck, Derrick convinced Uaall to cut his low-level bill out of the broilder package to be incormorated with milder high-level waste guidelines. After an initial sclback. the compromise measure went to the House floor for a vote on Wednesday.

- The House-Senate conference commit. tee will begin work on Thursday in reconcile differences helween the bill passed by the House on Wednesday and the Senilie bill. Derrick was chosen to seive on that conference committee. 
Dec. 3, 1980

\section{As I See It!}

The Greenville News has been risining some articles on nuclear energy-specifically the storage of nuclear waste. Jimmy Carter is not a big nuclear power man. $\mathrm{He}$ is not necessarily against it, but he sort of put nuclear power on hold for the last four years.

Ronald Reagan, on the other hand, has pretty much commit. ted himself to pushing nuclear power as an important source of power in this country. If he has his way, nuclear power plants may become more in evidence than they are now.

Nuclear power is a very dificult thing for $m e$ to form an opinion on. With the obvious in. lerruptions of conventional sources of power in the 1970's, it is necessary for this country to develop new ways of developing power. Nuclear power seems to iit. "in the category. of developmental sources of cower. and perhaps one that

๑. . $\bullet$

By Ed Crawlo:d

cannot be tossed out as unac. ceptable: Probably, our problems with energy because of OPEC have been greatly lessen. ed because of nuclear power. But the question still lingers in the mind of most people, is it safe? Furthermore how about nuclear storage? is there any guarantee that is is safe too? $\therefore$.lt depends on who you talk to. The people involved with nuclear technology declare it sale. They bring out all kinds of statistics to prove their point. Nuclear storage people feel the same.

The problem I nave: with nuclear waste storage and with nuclear power in specific, is its awesome nature. No matter what the chances of a nuclear accident. or that buried materials will seep to the sur. face, the effects of suchian accident are literallx mind-boggling. It: is not something: that we: would be able to control by sen. ding out the rational guard. It would be destructive to not only those who happened 10 be 100 close but possibly could effect generations to come. Nuclear storage may have even more serious implications. and this is close to home for us in jouth Carolina because we help slore nuclear waste in this state. Can you imagine the catastrophe if one hundred, two hundred years from now, if somehow that stulf got accidentlly opened or came to the top somehow? is it poss1. ble? That is what I keep asking myself. How can it be defended if it is not safe?

Our elected leaders must uitimately decide our fate in this matter. If is not sometting 10 rush into and it is something that will have a profound efiect or generations of Americans. Is it fair to burden them with something we do riol fotallv underslandr 
OREGON JOURNAL, POrtland, Oregon

Dec. 23,1980

\section{Let's mark $\mathrm{N}$-waste carriers}

Trucks hauling extra-wide, extra-long or extra-anything loads are often preceded by warning cars, or wear huge warning signs, or have warning cars fore and aft. The physical dimensions of the load make the caution necessary.

Trucks carrying gasoline or petroleum products are marked "flammable" or "inflammable" which both mean the same thing. Trucks carrying explosives are spe. cially marked. All these shapes and sizes and potentially dangerous commodities get their share of attention from the highway depart. ments and the drivers with whom they share the road.

It seems reasonable to expect an equal amount of control on the transport of nuclear waste and on other hazardous wastes as well.

It seems unreasonable that there are only three dump sites in the whole United States - Hanford, Wash., and one in Nevada, another in South Carolina. This means that all the material trom Three Mile. Island which will be shipped to Hanford will come in through Oregon, not to mention all the other states it will pass through en route.

Gov. Atiyeh wants the upcomIng Legislature to allow inspections of nuclear waste shipments and to require permits for such shipments through Oregon. The requirements for relatively harmless loads are strict and inspections frequent. It seems reasonable to ask at least as much regulation for more objectionable material 
Dec. 12,1980

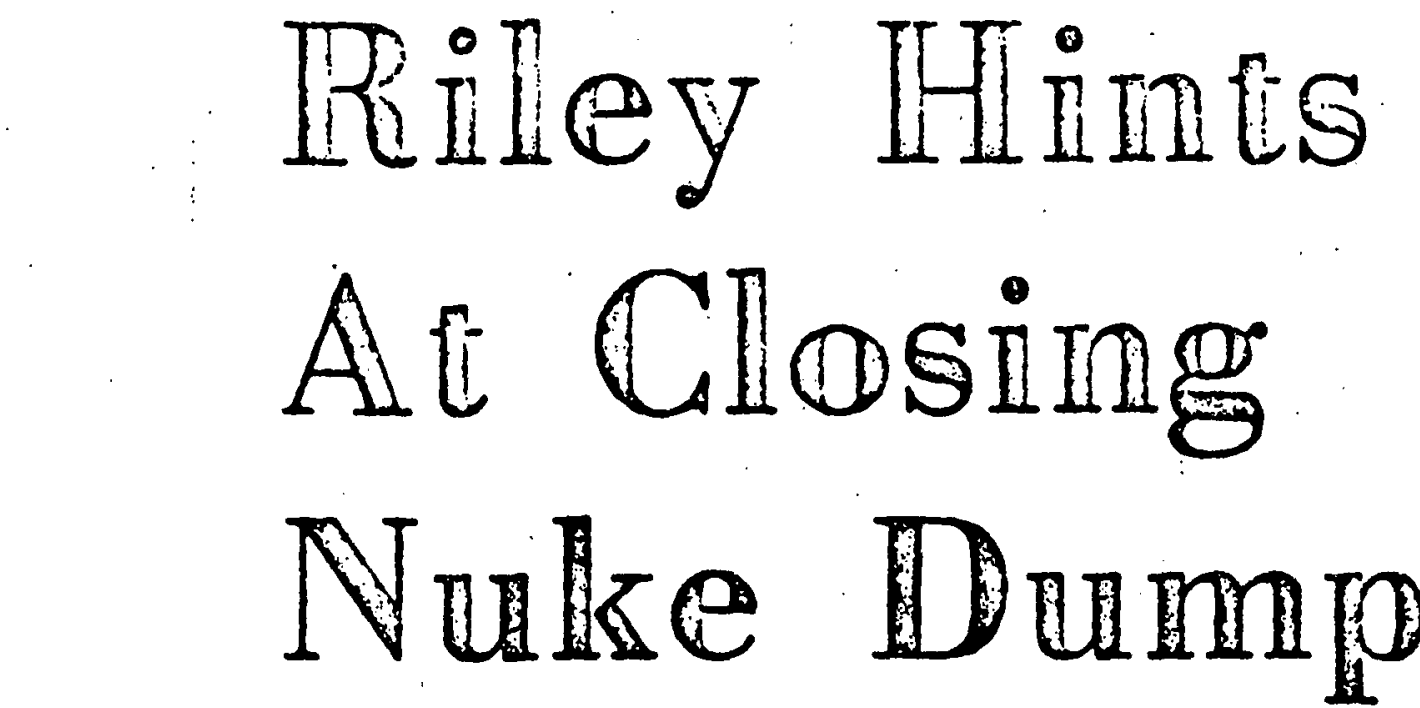

Gov. Dick Riley's staff. trying to send a strong signal to Washington. has mentioned in writing the prospect of closing the Chem Nuclcar Systems site to lou-level waste from nther states.

The governor is not close to taking that action. a spokesman said, hut is putting the option up for discussion in iry 10 get Congress 10 pisss a law ralling for regional hurial siles for liu-level waste.

AS IT HAS for some time, the hurial ground near Birnsucll talkes more of the nat: en's waste than any wher Ineation. Hiley has been on a campaifn lor monihs to $\mathrm{gct}$ olher areas of the country in hury their fair share.
Prospects for the regional burial legislation do not look good lor now. said Rep. Butler C. Derrick, D.S.C., spunsinr of the bill. Ite has been pushing a compromise bill that also deals with several other nuclear issues.

He said if a House-Senate conlorence committce fails to agree on Iegislation. then he 11 introduce the bill in Ihe next sessinus of Congress. though admitting it could be another five to six munlis before it passes.

AMONF; UTHTR STEIS, Riley aides suggested the governor consider biceping her states' lne. Invol nuclear "Iasle. frum hering shupped in
Barnwcll. the nnly such site in the east.

A year ago Rilcy sharply reduced the amount of low-level material that rould be brought to the facility, but the site still gets about half that produced in the nation.

There are two storage sites in the west. in Nevada and Washington, which could be closed within months. Washingtun voters said in November that without federal legislation making other states responsible lor their wistc. Its site should be closed.

inviada's waste site is projected to i. lull in 1982
Derrick said he would not favor a total ban on out-of-state waste hut nould support a lurther reduction in the amount permitted. another option suggested by Riley stalfers.

A stafl memorandum in the gov: emor this week suggested that a com. plete ban "may be just what is nerded to get the "mule's" altention" - "the triggering mechanism" In Ret all states to accept responsibilly for their own waste would be for states or groups of states in be able to exclude waste shipments.

The memo alsu said South Carulina could buck away fron its derision in allow cntry of any state's waste in limifnd animunls and restrict storrige to matcrial from suutheastern states anly.

All factions agree, accorting to Derrick. that states should be able to get ingether to select a location for disposal of low-level waste.

The House approved legislation last weck that calls for the creation of interstate parts to shift the respon. sibility from the three states to a regional husis.

(Ine of the primary obstacles to agreement came from Sen. Ilenry Jackson. D.Hashington, who did not want lo Rrant states the priwer tol reject their selection sites inr waste generaled from mililary arms prod. urliun. inld ll:mex. 


\section{$\mathbb{N}$ - Waste Disposal Bill Takes Statesmanship}

IF YOU start with the premise that nobody wants a radio. active waste disposal site nearby, then you can under. stand the trouble in getting Congress to agree on how to locate a disposal site.

A bill which would provide a systematic approach and a set of deadlines for decision-making on radioactive waste disposal is now in a conference committee of senators and representatives who are working against an ad. journment hour.

It is the first legislation of this type to proceed so far in Congress since the nation began accumulating nuclear wastes 35 years ago. For a quarter century, the federal government has fooled around with the problems and never developed a single permanent repository. As a result, 23 million gallons of waste are being "temporarily" kept in specially en fineered tanks at the Savannah River Plant.

Those wastes are from the government's nuclear weapons progium, and they are radio. active and dangerous. But they have been successfully contrclled and stcred without harm. ing the public or the environ. ment. South Cerolinians, how. ever, have a right to as!? whether that is to be the final resting place - and if not, where will it be?

The pending legislation is an attempt to answer that impor. tant question. The legislation also deals with the low-level, and less dangerous, nuclear garbage from hospitals, research, etc., which is now buried at a commercially run site near Barnwell.

U.S. Rep. Butler Derrick of Edgefield has been in the forefront of those pushing for this legislation. He has coordinated his efforts with Gov. Richard Rilcy who has taken the lead on tow-level waste dioposal policy in the National Governors As. sociation. They have gotten wide acceptance for legislation to authorize the states to agree to establish regional waste disposal projects.

That, of course, will relieve South Carolina of continued and growing acceptance of the nucle. ar garbage at the Barnwell site. It is one of three sites in the nation. About 80 percent of the wastes generated in the Atlantic corst states is dumped there.

Mr. Derrick told us in a telephone conversation earlier this weuk that the low-level watite plans appear assured of agrecment in the compromise committee. It is not so clear what the outcome will be on high-level waste plans.

We hope Mr. Derrick and his colleagues will be able to con. vince the conference members that the problems of high-and low-level radioactive waste disposal are national ones before they become crises. 
Dec. 12,1980

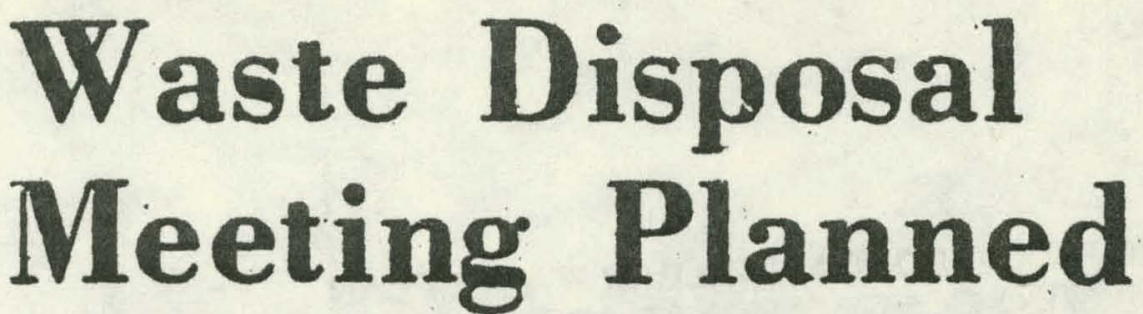

By CLARI SURRAT

comena mina

Representatives of nine states will meet in Columbia seat month to tall about a rezional program for disposal of low-level nuclear waste and hazandous chemical wastes; Gov.Dick:Riley said Wednesdias.

Riley said at a news conference the representatives will begia talking about a state compact: lor wast disposal, Suctr arrangenients:-vere. als. thorized in legislation passed by Con:

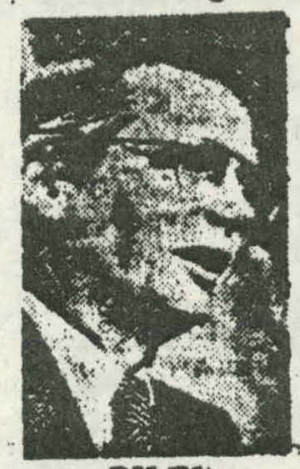

RILEY gress last week: - The other states involved In this meeting are North Carolis na, Georgta, Florida, Tennes. see, Virginia, Al: abama, . Mississippi and Kentucksy.

"We now a compact here in the Southeast," said. Riley. "We will talk about low-level. nuclear. wastes and thed hazardous chemical wastes.

The ide is to gits states or regions around the nation to assume more résponsibility for their own wastes, ah issue Riley has beeai pushing ; for months:-

South Carolinan: with: theiratas licensced Chen Nuclear Systeins fo' cility near Barnwell, now buries most of the low-level waste produced in the -astern halt otithe country

Under t the new law individual states can begin réfusing shiprinents irom other states as of Jan. 1, 1988.

RILEY SAIU HE had sought to get an earlier date, preférably 19\%, for this important trigget mechanism in the law.

On other subjects, Riley' said be will meet with representatives of the Carolina Brown Lung Association to day to discuss recommendations by him and the South Carolina Industrial Commission to speed up the handling of byssinosis (brown lung) claims.;

Riley said a major recommenda tion in the report is to have brown lung claimantia get a state-paid medical examination-immediately after. fliling for benefitt. The examinations would be conducted by doctors at state medical schools, which can be done now but? only: after a lengthier process. must first pay for their own medical examinations. Then if there is a meds cal evidence dispute between the clatmay' be reviewed by a state medical school doctor.

Riley said it witr cost about $\$ 7,500$. a year to pay for the examinations, and he will-seek- the funds from the State Budget and Control Board's corm tingency fund. He said when claims are upheld by the Industrial Com. mission, employers would reimburse the state for the initial medical ex. ams.

The CBLA, which works on behalt of textile workers seeking compens2. tion foc lung damage from cotton dust. has been protesting the length of time it takes the Industrial Commission to process claims.

The governor said he will not name a special panel to study brown lung benefits, as Gov. James Hunt did in North Carolina, because "I chosen to study it myself:"

RILEY- AESO acknowledgea Wednesday that the State Budget and Control Board", which he chairs, probabiy erred in approving money for stafk operations for . the State. Board of Chiropractic. Erčaminers last spring. two mon ths before the board members were appointed.

"Technically, that might have been a bad decision," said Riley. "It vias done a couple of months early."

Therefore, said Riley, the state Reorganization Commission did the rtght thing in requesting the attomey general to investigate the funding.

Riley said he did not recall the budget board's "going through a decision-making process on this; we have so many items on the agenda."

He said be didn't think the issue is ": situation of - high moral ques. tion.":
NOW, BROWN lung claimants mant and the employer, the evidence 
Dec. 19,1980

\section{NGA-DEVELOPED NUCLEAR WASTE PLAN WINS CONGRESSIONAL APPROVAL}

Legislation endorsing a regional solution to the disposal of low-level radioactive wastes has been approved by Congress and is awaiting President Carter's signature. The plan reflects the recommendations developed by the NGA Task Force on Low-Level Radioactive Waste Disposal, chaired by Arizona Gov. Bruce Babbitt, and adopted during the NGA annual meeting in Denver last August.

The bill (S 2189) includes two central principles in the NGA nuclear waste policy that each state be responsible for low-level wastes generated within its borders and that regional compacts among states offer the most promise for an equitable solution. Accordingly, S 2189 authorizes states to form regional compacts and to exclude low-level wastes generated from outside the region from the regional disposal site. Any regional compacts that are negotiated must be submitted to Congress for review, under the bill. The bill also authorizes the Department of Energy to conduct a study of the dimensions of the low-level waste disposal problem and the existing capacity to deal with it. The study would have to be completed within 90 days of enactment.

The NGA Subcommittee on Nuclear Energy, chaired by Idaho Gov. John Evans, worked closely with congressional leaders, especially Reps. Butler Derrick, D-S.C., Tom Corcoran, R-IIl., John Dingell, D-Mich., and Morris Udall, D-Ariz., in gaining enactment of the bill. The Subcommittee on Nuclear Energy was created in 1978 in large part to begin work on a solution to the low-level waste disposal problem. The first chairman of the subcommittee, James Edwards, who was governor of South Carolina at the time, was chosen this week to head the Department of Energy in the Reagan administration.
States have already begun.work on the development of regional compacts. On Dec. $1 k$, the Western Interstate Energy Board met to discuss compact formation. South Carolina Gov. Richard

A new report finds that states often receive inadequate representation in major cases before the Supreme Court. See inside pages.

Riley, who chairs the presidentially created State Planning Council on Radioactive Waste Management, has initiated contacts with other southern states on formation of a southeastern region. South Carolina, Washington and Nevada are the only states currently having commercial low-level waste disposal sites within their borders.

Also, northeastern and midwestern states are expected to hold meetings early next year on region formation. 
Dec. 1980

In-stute landfill disposal will be pusted in North Cacolina for low. level radioactive waste and for hazardous waste if the recommendations of 2 advisory committees are adopted by the Governor's Task Force on Waste Management. The committees recommended that the state develop shallow-land burial. sites for radioactive waste, that regional solutions be pursued-particularly with South Carolina, whose nuclear power reactors serve North Carolina in part - and that a plan for emergency, on-site storage of low-level waste be developed to deal with a possible closing of currently available disposal facilities. They also recommended, for hazardous wastes, setting up In-state landrills and emphasizing prevention, recycling, and reduction of the waste burden. The full task force is to report to the governor on the first of next year. 


\section{NUCLEONICS WEEK}

Dec. 18,1980

THE 96th CONGRESS ADJOURNED WITHOUT REACHING AGREEMENT ON A PROGRAM for managing highlevel and transuranic wastes and spent fuel. However, Congress did agree to a program for low-level wastes which it carved out of an omnibus waste bill and passed last Saturday (Dec. 13). The Low-level Radioactive Waste Policy Act assigns states the responsibility for low-level commercial wastes generated within their bound. aries. The wastes niay be dispused of within a state, or soinewhere in the region through multistate compacts. These compacts must be approved by Congress and revicived every five years.

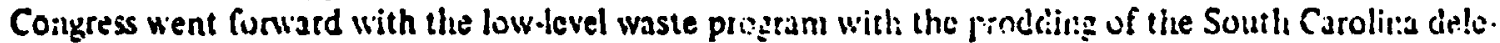
gation. Curresilly theri are only three states which contain low-level waste disposal sites: Wasting? onn. Newar!. and Snuth (arulina. Wistington voliers recently decided to seiendy restrict the anount of low-level waste the state will accept. and Nuvada's governor wants to close tlie Bejuly site. "It is grossly unfair. univise and unacceptuhle to expect South Carolina to assume this disproportionate burden indefinitely," Sen. Strom Thurmond (R-S.C.) told his colleagues during debrte.

Prospects for pussage of a broxder nuciear waste bill scemed briglt earlier this month when the House finally reached agrecinent on a nuclear waste management bill five months after the Senute agreed to a waste bill. It appoured kiy senators were prepared to acient the House version with minor amendments. although that bill omitied major provisions of the Senate bill such as away-from-reactur sturage of spent fuel. Questions about Al:Rs. retriswible storuge. and other features of the Senate bill couls wait until next term for resilution.

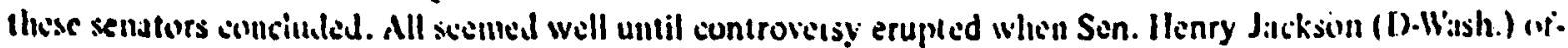

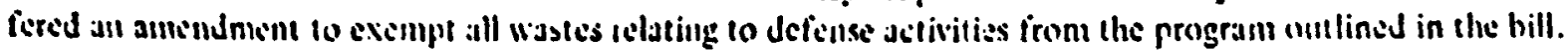

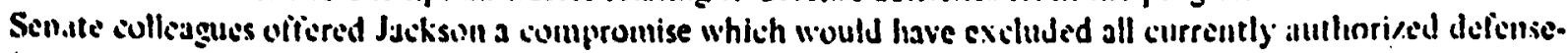

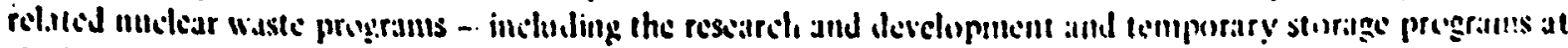

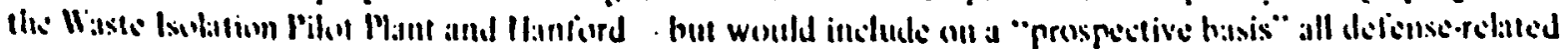

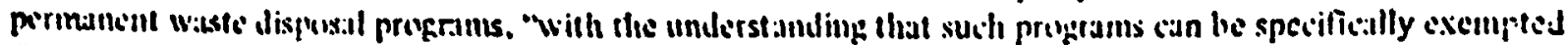
from the provisions on the act in the interest of national security at the time such prongrams are anthoried."

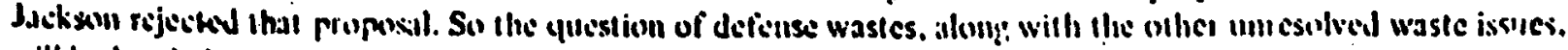

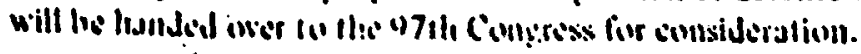


Dec. 19,1980

Mudear Enorey

\section{ONLY LOW-LEVL RAOIOACTIVE WAOTES}

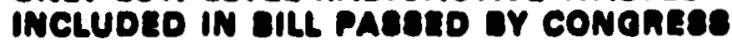

Unable to artee on a comprehensive nuclear wasto management bill, the Senate and House Dec. 13 passed by a volce vote a bill that deals only with setting up repositories for low-level radianctive wastes.

Under the bill, "the Low-Level Radioactive Waste Policy Act" (S2189), states are responsible lor providing low-leved radionctive waste disposal capaclty for wastes generated in their states, exeept for wastes generated by the milleary or federal resenrch and development activities.

To carry out that reaponsibility, the bill autborizes states to enter compacts to establlih and operate rejonal dispoul facilities for low-level radionctive wartea.

However. Congress would have to approve each compact and every five years thereafter could vold the compacts.

After 1986. a compact could restrict use of a regional facility to wastes generated within the regton. The bill orders the Department of Enercy to submit within 120 days to Congress and to the states a report that defines the regional disposal capacity needs, defines status of all commercial low-level radiosctive waste disposal sites, evaluates transporation needs, and evaluates the present capability of disposal sltes owned by DOE to provide interim storage for the wastes.

The blll, is esseatially the version of 52189 that the House passed Dec. 3 (Current Developments, Dec. 5, p. 1177) with amendments made by the Senate that deleted all sections of the bill not relating to low-level wastes, and specifying that the bill does not cover military wastes.

The House and Senate reached an impasse on the House bill the week of Dec. 8 when Rep. Morts K. Udall (D-Ariz) and John D. Dingell (D-Mich) refused to agree on an amendment introduced by Senate Energy Committee Chairman Henry M. Jackson (D.Wash) that all millitary wastes should be excluded Irom the comprehefistive House blll, which would have established repositortes for high-level nuclear wastes and spent fuel, in addition to the provision for low-level radioactive wastes.

"Although the most complex and urgent radionctlve waste disposal problems still remain before us, I am gratifled we could at least address this lssue," Udall soid on the House floor Dec. 13.
At that time, Dingell noted that "time constraints enabled a few senators to hold out lor a position which was not consistent with the House bill and curiously was also not consistent with the Senate bill."

Udall and Dingell said completing working on high-leyel waste repositories would be one of their highest priorities in the 97th Congress.

Renee Parsons, of Friends of the Earth, told BNA that the low-level waste bill is "responsible," but that Congress has yet to agree on any of the controverslal issues for comprehensive nuclear waste management.

Parsons added, "Udall and Dingell now have commitied themselves to a comprehensive nuclear management bill that includes military wastes. And I think with a coaltion like Glenn, Percy, Hart, Udall, and Dingell, Jackson better reevaluate whether he wants to stay with his position.

Senators Gary Hart (D-Colo), John Glenn (D-Uhio). Charles Percy (R-Ill), and Jennings Randolph (D-WVa) had sent a letter to Jackson urging him to accept the House position on millitary waste.

According to Laura Worby, staffer on the Senate Envrosment and Public Works Subcommittee on Nuclear Regula. tion, the push toward a compromise bill came from Rep. Butler Derrick (D-SC). South Carolina is one of only three states with commerical low-level repositories in the United States. 
Nov. 7. 1980

\section{State, Federal Government}

\section{Agree On Waste Shipment Plan}

\section{By MIKE LIVINGSTTON Govemmental Alfairs Sult}

Gov. Dick Riley announced Thursday that differences between the state and federal governments regarding shipments of federal nuclear waste in South Carolina have been resolved with the signing of an innovative agreement.

At issue was a new state law controlling the movement of wastes that did not exempt the Department of Energy and Department of Defense shipments from state control - a move that drew federal resistance.

The federal government, Riley explained, did not want

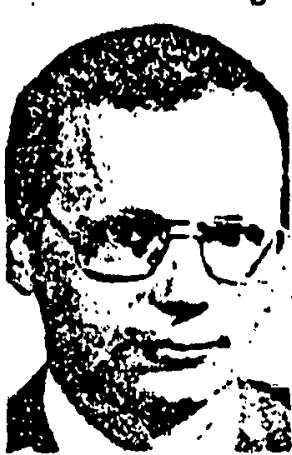

GOV. RILEY to run into a barrage of controls installed by the various states that might vary greatly.

"Federal officials communicated to me that the new law should not apply to federal shipments and I felt that there should not be a wholesale exemption of shipments made by the United States government," said Riley.

"My respotisibillty as governor involves the health and safety of all South Carolinians. Nuclear waste is nuclear waste and I must concern myself with all waste regardless of its origin. So I feel all generators and transporters of nuclear waste should adhere to these new standards," he said.

The "principles of understanding" signed by Riley and federal officials allow the federal government to forego obtaining specific transportaton permits from the state. but the state will still receive prior notification of all shipments.

ADDITIONALLY, the state maintains the right to suspend or revoke the waste disposal privileges of any federal generator shipping waste to either the Chem. Nuclear Systems low-level nuclear waste dump near Barnwell or to the federal Savannah River Plant.

The department of Health and Environmental Control monitors shipments at Chem-Nuclear. And Riley said enforcement procedures have been established at SRP between that plant's operations offlce and DHEC.

If a shipping violation occurs at SRP and the DHEC commissioner is not satisfied with the action taken, the new agreement provides that the matter be handled directly by the governor and an undersecretary of energy, Riley said.

"The big problem in nuclear waste has been this intergovernmental situation - the problem of who does what," he said. "This is an example of a state which made a strong move in the regulation of wastes and which negotiated with the Department of Energy to everyone's advantage." 
Nov. 7,1980

\section{U.S. To Follow S.C. N-Waste Laws}

From Assoctated Press Renorts

COI.UMBIA - Cov. Dick Riley amiounced Thursday that the fed. cral government has agreed to comply with S.C. laws controlling transportation and disposal of low-level radioactive wastes.

Riley said the agreement with the U.S. Department of Energy (DOE) means waste shipments from rederal nuclear facilities io two S.C. sites will be subject to the same safeguards a new state law forces on commercial ship. ments.

The agrecment was reached afler Encrgy Department officials. citing the Constitution, said feder. al shipmenls wouldint be subjecl in a state law cnacled last spring. kiley said, beratusc ferieral law overrides state law.

The state law, for the first tinic, establishes civil penaltics for cer. tain violations and allows the state in revoke licenses of repeal offenders.

The governor said the main diflerence between the agreement and the statc law is that federal facilitics won't have to receive the permits required of commercial operations.

"The big problem with nuclear wastes in this country has beclu intergovernmental - who can do what to whom," Riley said. "Under this agrernirnt, DOE has agrecd to do the same thing lhey would liave to do under the stale law."

Soull Caloulina is one ol threc states with lacilitics licensed in store Inw-Icvel nuclear sarbage. The others are Washington and Nerida.

Riley said the agreement re. quires that the state reccive priar notification from lederal facilitics and contractors planning to ship waste in cither the Savannah River plant or the privately oper. atrd, state-owned (hem-Nuclear Systems duinp. Both are near Barnwell.

$A$ ycar ago Rilcy began 10 phase down the amount of waste Soutr. Carolina would accept. The Chem: Nurlear dump in recent years has recciled as much as 35 precent of the nalion's luw-Ierel rarlinadive Earbatge. 
NEWS-PIEDMONT, Greenville, S.C.

Nov. 17,1980

\section{State now has better grip on nuclear waste problem}

Gov. Dick Riley has led his state toward reasonable handling of nu. clear waste -while providing leadership for a national or at least interstate policy toward expected future expansion of the field.

The federal government, in al. most complete absence of any regu-. lations of its own, now agrees to comply with state laws controlling transportation and waste disposal.

Federal wastes now will be sub. ject to the same oversight as com. mercial operations on which Riley and several other states cracked down severely some time ago.

Proviously federal shipments were not subject to state authority. traveling under protection of a constitutional supremacy concept.

Essentially Riley's power as a nuclear waste leader was brought to bear to keep his promise that South Carolina not become a nuclear dumping ground.

It was a pressing issue because the state was receiving up to 85 percent of the nation's total load, plus heavy shipments of international waste.

Extension of the atomic regulations to federal shipments is not designed to hamper out-of-state nuclear programs in any way. It merely gives the state ultimate con. trol over shipment methods - many of which have been found to be faulty - and site storage.

Riley also has wisely led the fight toward regional compacts to handle nuclear waste, which appears to be the best answer because the federal government does not seem able to come up with better plans.

While South Carolina's share of the dump need not be excessive, the state will continue to play a large part in protecting and promoting the nuclear future of the country, even if other states selfishly refuse to participate despite their hefty contributions to the leftover atomic piles. 


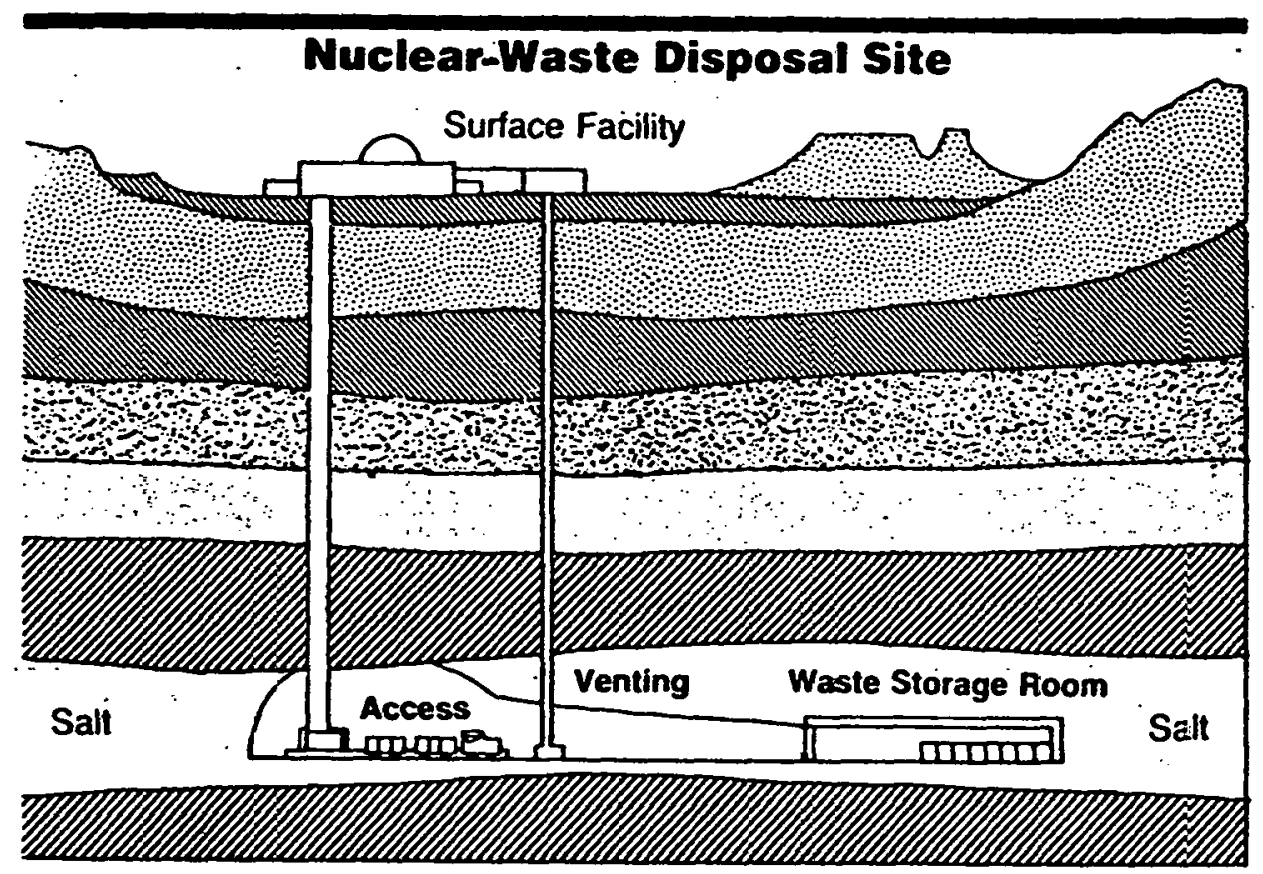

\section{Nuclear-Waste Sites Decline}

The growing dilemma of nuclear-waste disposal has citizens and public officials in many states mobilizing to prevent nuclear wastes from being stored in their re gions or even trucked through on public roads.

The three states with commercial burial grounds for low-level radioactive trash are sonsidering closing them or limiting what they will take. California officials nervously are examining the effects of radia. tion leaking from thousands of barrels of radioactive wastes dumped off the San Francisco coast in the 1950 s and 1960 s.

\section{Time Running Out}

At the same time, the nuclear power in dustry and utilities are running out of room to store burned nuclear fuel and are bring ing pressure on the federal government to store it for them. sion.

\section{Election Intensified Problem} wastes in their back yards.
Low-level wastes, which can be very radioactive and quite dangerous to living creatures, include contaminated paper, plastics, construction materials, tools, pro

tective clothing, industrial wastes and contaminated trash produced by nuclear medicine.

Waste Has Many Sources

Of the 100,000 cubic meters of low-level wastes annually buried in the three com mercial dumps in the United States, about 43 percent comes from nuclear-power plants, 25 percent from hospitals, 24 percent from industry and 8 percent from the federal government.

The Energy Department also buries about 50,000 cubic meters of this waste each year in its own dumps.

Three other low-level commercial dumps have been closed. One. ai Shieffield, III. was closed after it was filled in 1978. Two others, at West Valley, N.Y., and Morehead, Ky., were closed in 1975 and 1977

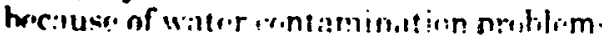

For 25 years, until 1970, a great deal of low-level waste was put in metal barrels and dumped at 50 sites in the ocean. Officials of the Environmental Protection Agency say one-quarter of those burrels now: arc leaking. Experts disagree on the environmental effect of the leaks.

\section{Wastes Travel Far}

Low-level wastes currently are buried in dirt-covered trenches at the three dumps. On the East Coast, where most nuclear power plants are located. there is only one dump, at Barnwell, S.C. Because that .facility can't accept liquid wastes, trucks must carry this garbage to Hanford, Wash., from as far away as New England.

Claiming that federal regulations concerning the packaging and transportation of these wastes were being ignored, the states of Nevaca and Washington in 1979 ordered their dumpıng grounds closed for several weeks. This closure awakened other states to the impending crisis.
Despite this growing public concern over disposal of radioactive wastes, Congress never has enacted a national nuclear waste plan and it is unlikely that Congress wil pass a bill in the current post-election ses

But the Nov. 4 election may have pushed the problem closer to the front of the line of those decisions the 97th Congress must face next year. Voters in several states made it clear they don't want radioactive

The most immediate problem is the burial of "low-level" nuclear wastes, which are generated in every community in the United States. There are only three dumps for this type of waste in the nation. Washington voters decided Nov. 4 to close that state's dump next summer. The governor of Nevada has pledged to close his state's burial grounds and South Carolina has cut in half the amount of waste its dump will take.

The National Governors' Association and other organizations of state and local of ficials say the disposal of low-level wastes should be a state responsibility. But they say legislation is needed from Congress stating this and giving states the authority to enter into regional compacts to handle radioactive trash.

\section{Feds Face Dilemma}

While the states face the low-level waste problem, the federal government must decide what to do with high-level wastes generated in nuclear reactors and in producing nuclear weapons. Some of these wastes remain radioactively hazardous for hundreds of thousands of years.

President Carter announced in February the government would take a safetyixs! approach to finding permanent repositories underground. 
Nov. 6,1980

\section{Westerners Vote To Ban Storage}

\section{Washington State Initiative May Help Riley's Nuke Plan}

\section{By MIRE LIVINGSTON

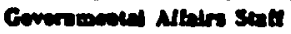

The state of Washington's overwhelming vote to ban storage of most out-of-state low-level nuclear waste may have given Gov. Dick Riley's push for Interstate burial pacts a shot in the arm, a Riley aide said Wednesday.

WASHINGTON IS ONE of only three low-level burial ciounds in ihe nation, line other two being in Nevada and at Chem-Nuclear. Systems in Soutb Carolina near Barnwell.

Chem-Nuciear at one time received more than 80 percent of the nation's low level radioactive waste, more than half coming from seven states in the industrial Northeast and Midwest.

A year ago, Riley began a phase-down on the amount of waste South Carolina would accept and started pushing other states to take care of their own waste or, even better, create multi-state compacts for waste disposal. That idea is currently gaining momentum.

The initiative by Washington voters - which probably will be challenged in court - is a "two-edged sword," in that it may reduce further the avallability of dumping facilities, but at the same time put more heat on states to build their own, said Riley's executive assistant David Reid:

"It does put more pressure on those states which generate signiticant amounts of low-level nuclear waste to move quickly to create sites in their own states or enter into a compact with a state that does have a site," he said.

"Now there are a number of states - Virginia being the most active - that are working hard to create a disposal site within their borders. This is going on in Texas, Illincis, the New Ergland region and North Caralina has a task force looking into it.

"THE PRESSURE HASN'T been coming to us - it's the other way. We are putting pressure on the generators to build a waste site or join a compact.
"And things are moving very well for the interstate compacts. The' National Governors Association and the National Conference of State Legislators have agreed with Riley's proposal that this is a matter for state government to deal with.

"And the responsible, preferable method is to create Interstate compacts for regional disposal sites," he said.

Currently under R!!ey's phzse-dcwn plan for ChemNuclear, the facility is recelving only about half of the nation's low-level waste, or about 14,000 - cubic feet per month. At the high point, South Carolina was taking more than 200,000 cubic feet. And by this time next year. ChemNuclear may accept only 100,000 cubic feet per month.

The Washington initiative, which has not yet been reduced to specific legislation, excludes radioaciive waste from medical facilities and also from those states which agree to develop their own sites. 
Oct. 30,1980

\section{NRC's List Of Waste Shipment Routes Stirs. Up A Storm}

"If's the worat sines TMI." That's how the Nuclear Regulatory Commlealon'e public affaire offlce describes response to the NRC's Hrat "publle information circular for ahipments of irrodlated reactor fuel," Issued last woek. The circular, the first in a proposed sorios of somiannual publications on spent fuel shipmante, gives atatlatical information on: NRG-epproved routes for spent fuel shipments; cumulative amounts of imaterial shipped in a given perlod; and ony eafeguards-alginificont incidente which have oc. curred along the approved routes (there haven't boen eny Yor, NRC sayal. NRC information staff were kepe buey all weokend answering querles from "ovary newepaper in every etate". On the clreular's list of 33 stares, sald spokeman Joe Fouchard.

The NRC statistice show that a total of 94 shipmonts involving 48,710.7 metric tons of epent fual were made botween July 16, 1979 and Septembor 10, 1980. The largest amount of materlal besween two pointe was 36,000 matrie tons, shipped In 10 batches botwoen the Robincon nuclsar plant in Haetsville, S.C., and the Brunawick site in Southport. N.C. Sovan thouand matrfe tons wore shipped from San Onofre, Ca., to Morrls, III. In 14 loeds. And some 1,800 motric ions wore shippod out of the fort St. Vrain gat-cooled reactor to the Idaho National Enolnooring Laboratory to await roprocessing by Exxon Nuciloar. 
Vol.2, no.20, Oct. 6,1980

\section{TIME IS AGAINST MET ED AND NRC ON TMI-2 WASTE, NRC STAFFER SAYS}

The low-level waste resins inside 49 of the 69 canisters of waste sifted from $500,000 \mathrm{gal}$ of contaminated water from the auxiliary building at TMI-2 could become so degraded through radioactivity that solidification might no longer be possible, according to an official of the NRC office of nuclear material safety \& safeguards (NMSS). "Time is against us," he warned.

The 49 canisters contain nearly all the radioactivity from the total 69, he said - some 55,000 curies of mostly cesium-137. The possible danger is that the resins could degrade from their current form of beads to possibly a jelly tike or molasses tike mass that might give off gases and corrode the containers. The radioactivity of the $\mathbf{4 9}$ canisters is some $\mathbf{4 0}$ times higher than that from resins from a routinely operating reactor, the staffer said.

The NRC commissioners have mandated that the wastes be solidified before they can be transported although the licensee, Metropolitan Edison, disagrees. So far, no firm solidification plan has been approved, although Met Ed has worked on cement solidification.

In addition, the NMSS staffer says, the results of a November referendum on the Hanford low-level wastediponal dte may mean thet wastea will be prohibited there after July 1, 1981. Nevada is considering closing its its - and Mal. 2 wath is excluded from the South Curolina wate disposal site.

The low tevel wate from the audiling building b problem enough, the staffer told Inside NRC, but wante chors to highterwl waste is in mived in the resins that will be collected from processing the $700,000 \mathrm{gal}$ of wete in the containment bullding. That water is 10 times as ndioactive as the already processed water from the suxoltery building - with 500,000 curles of both cosium-137 and strontium-90. That waste, he says, will fill about 50 containess with radioactivity of 1,400 curies per cu $f t$. This is where the NRC staffer is convinced thet DOB should come in to halp.

However, the DOE vewpoint, according to one DOE staffer, is that the TMI-2 waste hes too thort a halfHo (about 30 yeara) to be deflned an hightevel waste, and that by law TMI-2 wasto cannot be depositod in a dofeme facility.

Alo at inm is the method to be ured to purify the contuinmeat water. NRC maintains that an excellent job of purtication was achieved with the auxillary building water through use of the Epicor II syrtem - but

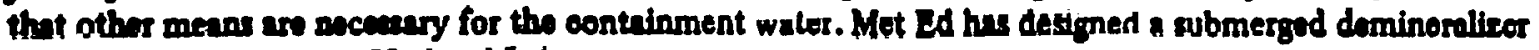
yitem which Oak Ridge Nationsl Laboratory ays must be improved, an opinion shared by NRC. One posdWilty, the NRC stefier aid, is that tho demineraltzer system may be used in conjunction with the Epicor II mettiod.

Met Ed would like to use shallow burial for the containment building resins, on the assumption that no NRC rezulations exdit to any this can't be done, the NMSS staffer sald. But, he said, "We've never dealt with wro like this. There are no regulations designed for it. Wo've never seen anything like it."

Tho third sizable quantity of water - some $100,000 \mathrm{gal}$ - still to be processed is the primary coolant system in the pressure vesel. This is low radioactive than the sump water, the NMSS staffer syys, but it may ponibly have transuranic wastes in it like uranium and plutonium. Also, that water must be recycled continually wo that the primary syntern doeen't go dry. - Joanne Dann 
LOW-LEVEL WASTE CONFERENCE - Transportation problems and the urgency of developing new disposal sites were some of the issues addressed at an NCSL-sponsored low-level radioactive waste management conference held in Albuquerque, New Mexico, August 17-19.

Co-chaired by Senator Paul Hess of Kansas and Representative Gordon Voss of Minnesota, the conference faculty and participants represented legislatures, legislative staff, executive agencies and industry from over orie-half of the 50 states.

The three-day session, hosted by the New Mexico Radioactive Waste Consultation Committee, began with an overview session designed to present the scope of the problem. Moderated by Davie Reid of South Carolina Governor Richard Riley's staff, a panel composed of representatives of industry, nuclear medicine and an environmentalist group, discussed the different generators of low-level waste and potential environmental hazards. Hesward Shealy, South CaroIina's chief radiological health officer also presented a historical review of federal-state roles in the regulation of waste disposal.

The remaining presentations focused on state activities highlighting a myriad of legislative approaches to low-level radioactive waste management which range from disposal bans to requiring legislative approval prior to site suitability investigation. Perspectives of three states affected by different aspects of the waste cycle were examined. New York Assembly staffer Bob Kurtter represented a generating state, Dan Kemmis, a Montana state representative, reviwed transportation concerns, and Washington Senator Al Willians discussed the views of a state hosting a disposal site.

National initiatives and federal agency responsibilities were described by representatives of the Nuclear Regulatory Comission, Department of Energy, a DOE task force which developed a national strategy for low-level waste management and the President's State Planning Council of Radioactive Waste Management. Elgie Holstein of NCSL's Washington, DC staff reviewed pending Congressional legislation dealing with low-level waste. Following these various perspectives, the particpants attended concurrent afternoon workshops on the topics of transporation systems, disposal site selection and management, and interstate compacts and agreements:

In order to solicit feedback from the participants, the last day of the meeting consisted of a series of regional discussion groups. States assuming responsibility for managing low level wastes and endorsement of a regional management approach were supported by legislators involved in these discussions. Legislators at the meeting also encouraged NCSL to work with the National Governors' Association and the President's State Planning Council in conducting six regional conferences to explore options for regional approaches to managing low-level wastes. The need to involve key legislators from each state in the advance preparation for each conference was emphasized, and it was also suggested that in addition to governors and legisiators, representatives of other state and local organizations should be invited to participate in these conferences. 


\section{NUCLEONICS WEEK}

Aug. 28, 1980

NECOTIATIONS FOR DOE TO BUY TIIE BARNWELL. S.C REPROCESSING PLANT will begin soon if an enabling amendinent authored by Rep. Don Fuqua (D.Fla.) gets through Congress and gains White flouse approval. According to a congressional source, the Fuqua amendment "not only authorizes, but directs the DOE Secretary to negotiate the purchase." Fuqua's amendment is being carried ou DOE's research and development appropriations bill for FY.81 and on another bill which establishes and funds a fusion engineering test tacility, in hopes that one bill or the other will become law. To have any hope of becoming effective this year, the amendment must pass through Congress by Oet. 4.

The amendment specifically provides \$11.5-million for Barnwell: \$9.million for keeping up Barnwell's red programs in away-from-reactor (AFR) storage and nuclear safeguards, and \$2.5-million for negotiations to acquire the reprocessing facility through outright sale, leasing or condemnation. According to a source at Allied.General Nuclear Services, which owns and operates Barnwell. "They've done some tinkering with the amendment for the sake of compromise. A provision that Barnwell be acquired for AFR storage was deleted in exchange for stronger language on DOE's intention to negotiate the purchase." Despite this. a conflicting provision still attached to the amendment mandates negotiations for AFR storage arrangements at Barnwell; to be in effect until final purchase arrangements are negotiated.

The congressional source said that the amendment's passage through Congress should be smooth. "There won't be any trouble in getting it through Congress," the source said. "The trouble will come when the bill hits the White House. Now, I don't see how the Administration can turn it down. Of course, Barnwell's a reprocessing plant, but on tho other hand the plant's about two years from completion. The bill would also give the governnient control of the facility." A White House spokesinan had no comment.

Work on the Barnwell reprocessing plant was stopped in 1977 following President Carter's decision to defer commercial reprocessing. "There's a moral basis to this bill, too," the congressional source said. "We allowed these people to build the plant, but then we didn't allow them to use lt. That certainly puts the govern. ment in a shaky moral position."

The amendment states that the Barnwell negotiations must be completed by the time DOE's FY.82 authorization is submitted to Congress, which should be in January 1981. "We don't expect any trouble with the negotiations," an Allied.General source said. "Besides, this is a foot in the door on the problems faced at Morris and West Valley. It's a plus." 


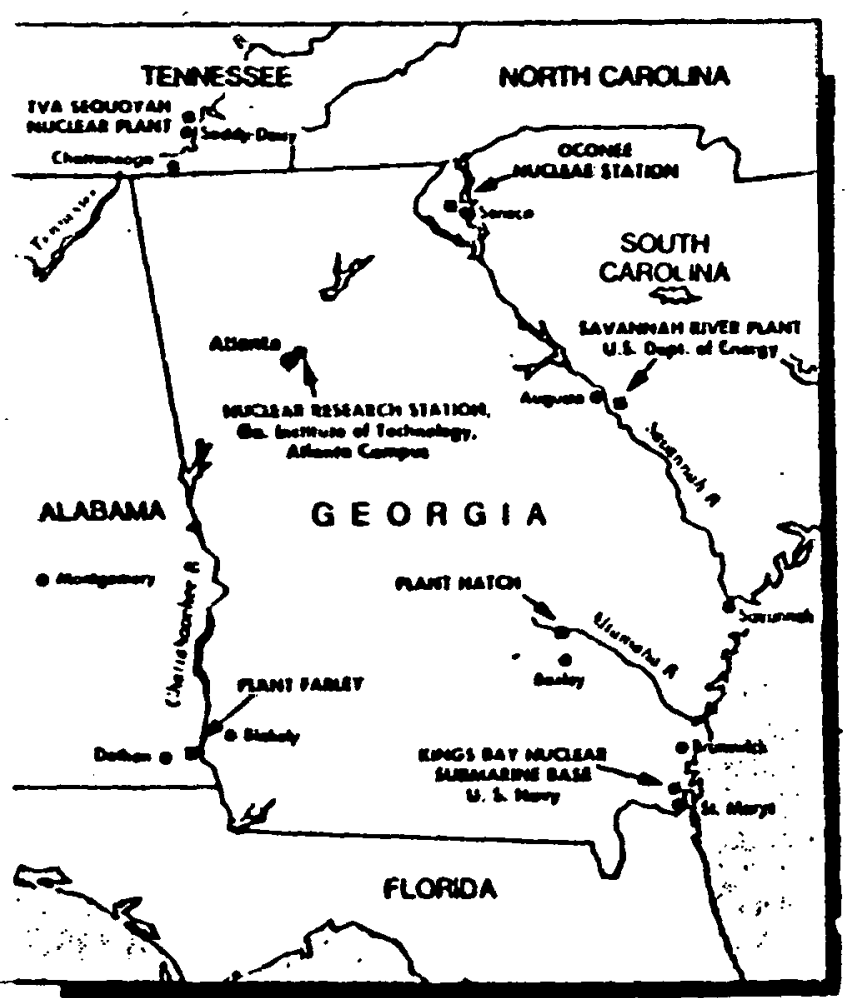

Hap showe neclear testallettone is Georgle and around its bor. Jen. Ewerzency plans for Georgle isclade the state's one arjear plant, and seligborlos obes in Tenaessee, South Carolioa and Alabome, plas sack noctear facillites as the Savannat Aver Plant in Sont Carulias, the Klage Bay Neclear Submatoe Base in St. Marys, and Georgla Tech's Naclear Research Statlea in Allante filll Anwort-Jere Werrea)

\section{State Officials Map New Plans}

\section{In Case Of Nuclear Emergencies}

\section{By Stares Balley}

In the wake of the Three Mile Lslund nuclear-plant accident, Ceorgla officials have upgraded state plans and equit nent to cope with emergencies involving radioactivity, a state envirunmental protection olficial said Monday.

The state's new emerguncy plan to protect the public iro.n radiation elltergencies is now being reviewed hy lederal olficials, and Ceorga has added a mobile liburalory equipped wich devices to analyze radiation to its arsenal of emergency equipment, according to Bill Cline. environmental radiation progran manazer for the Department of Natural Re surces.

Cline said the emergency plan in cludes a general section on how the state mould bandle radiation encirguncies Whether they cccurred at nuclear taciliUles, hospitals, resuarch laboratories or ouber sites - plus a detailed plas lur each of the najor nuchear facluties in or adjacent to Georgha.

Clune said decailed plans have bita de- veloped for four oucliar power plants. including Plent Hatch nedr Baxley. lle TVA's Seyuoyah Nuclesar Plant just nurth of Chatuonooga; Plant Farley in Ala bama, southwess of blistuly, and the Oconee Nuclear Slatiun in Senexd, S.C.

In addition, detailud enlergency frine dures have been prepurcil in case of al accideal involving the U.S. Saviouial Hiver Plant near Auguila, a goveranich facility which processes nosterisl for nuclear arms; the US. Novy's Kin's buy Nuclear Submarine Support Base in Camden County; and Geurgua Tech's Nuclear Pesearch Center on the Texth campus, he said.

The state has also dcveloped a de blled plan to clipe with dccidents Invulving the transportution of nuclear matcrials thruugh Cerrisia.

Cline said the new erinerfency axids ures are awaiting review by the fechural Emergency Manageiuint Abency, which expects to coniplete its izallithativa of the ducunseat at the resivial bevel by the. end of this montb

"I'm very confiscal aboul uur plan."
Cline sald adsug. Hiat the ilate has the capalility to "to liatidle a Itatece Mille Is

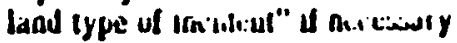

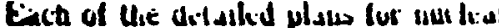
paciluties includes medsules for thi prolection or evacuation of pelsusa: witbis a 10 mule tatius of the slie. plu: meidsuras 10 clicect midcr supulues distes, storted almnal tecd altul simulat llems withon a solmule radius 10 mali sure conbmiliallon bas aut cheursed ut is not spread elocwhere, he sind.

As part ol its eflurt to uygrade it "precinteduess" tor radivacluve emerg:0 cies, Cline wald. Hit state has speit 880. 000 to \$100,000 buying sist eyulpping van with soplustlcaled equipment $w$ in usted to anslyze the annount and tiod 0 raliatiun lo case of all accident.

The vall could be at Plans Italct o Plask fartey witlin iwo hours of mols ficatiun of in elikergedicy. allal kestlii. cuuld be continple'ted willin all hour in

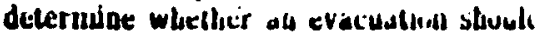
be ordered, he salds. 
Vol.2, no.1, Aug. 11, 1980

\section{GOVERNORS ASK FOR REGIONAL TRADE-OFFS ON RADIOACTIVE WASTE}

States should be responsible for handling waste problems in regional associations working under federal insentives, according to a report released last week at a National Governors Association (NGA) meeting in Denver.

The report recommends dividing the U.S. into six regions. Any regional association of states working together under a formalized agreement would decide jointly on a disposal site and could then exclude radinactive waste from states outside the region. However, the governors' report leaves a number of "floater" states that can choose which region to join.

The report provides limited guidelines on siteselection procedures including a "trade off" recommendation. Using this method, a state which accepted a radioactive waste dump could then send its industrial hazardous waste to another state.

Washington presently takes Oregon's nuclear waste and Oreson screpts toxdc chemical waste from Washington under 2 trade-off agreement.

Economic compensations to the state accepting a lowlevel dump are recommended in the report. It suggests direct payments to be financed by both the federal government and the nuclear industry. The siting problem is viewed as "political," with no state likely to want a dump within its borders. NGA considers incentives the necessary "carrot" to save what has become an intergovernmental problem.

Public participation during site selection is strongly recommended by the NGA report, with state legislatures ratifying final decisions on siting.

Existing sites for low-level waste are inadequate, according to the report. By 1990, there will be three times as much low-level waste as there is now. Sites in Washington and Nevada were closed last summer because of violations of shipping and packaging regulations (See HWR, Vol. 1, no. 11, p. 13). South Carolina also curtailed the amount of waste it will accept. The Nuclear Regulatory Commission estimates that it takes two to four years to develop a disposal facility. 
Aug. 8, 1980

\section{Nuclear Eneroy}

\section{CAO OFFICIAL URGES TVINC PEDERAL AID IN WEST VALLEY CLEAN UP TO FUTUAE U8E}

Linking federal help in cleaning up nuclear wastea at the Western New Yort Nuclear Service Center, Weat Valleg. N.Y., to possible use of the site for storing nuclear wastes and spent fuel is a "practical solution" to local and national needs, a General Accounting Offlce official suld July 28.

J. Dexter Peach, director of GAO's enercs and minerals division, told the Rouse Commeres Subcommittee on Energy and Power that a receat GAO report (EMD-80-89, June 6, 1980) concluded that the Federal Government should assume some responsibility for cleaning up the Weat Valley site, but in returm and if found technically adequate, the state should agree to reopen the spent fuel storage faclity to serve as a regional away-from-reactor (AFR) storage pool and tho low-level waste burial grounds as a regionn burial site.

New York Covernor Hugh Carey told the subcommittee that the current agreemeat with the Departmeat of Enerw does not preclude the use of the site if it is lound to be suitable. Nevertheless, Carey wild he supports IIR 6865, which does not link future use of the lacility to the proposed solidification project. "Just because West Vallieg is a reprocessing center does not automatically make it the most suitable (AFR) site, "he stated. Selsmic, geological and water leaching conditions should be asseased thoroughly before AFR decisions are made, Carey sald.

In response to Carey, Congressman Pull Gramm (D-Tex) said if the Government pays 90 percent of the costs of the project, as proposed in HR 6865, the Covernment should be given some assurances by the state that cltizen's fears or objections will not preclude the use of the site.

Under HR 6885, introduced by Congreaman Stanley $N$. Lundine (D-NY), a 85 million demonstration project would be established to solidify some 600,000 gollons of high-level liquid radioactive wastes. Total costs of the project are es. timated by DOE to be $\$ 180$ million, which would be shared by the Government and the strte at 90 percent and 10 percent, respectively. A similar measure, $\mathbf{3} 2443$, already has been approved by the Senste (Current Developmeats, June 20, p. 284).

\section{Sofoty of Facilides Disputed}

DOE, the Nuclear Regulatory Commission, and Nuclear Fuel Services which currently is responsible for the site, told the subcommittee that the spent fuel storage pool facillties can be reopened safely and used for AFR storage. C. Worthington Bateman, under secretary for DOE, noted however that DOE currently does not have authority to administer an AFR program. But if Congress provides such authority West Valley and facilities at Morris, III., and Bamwell. S.C.. would be candidates for providing near-term storage capacity, he added.

At this time, Bateman said, DOE wants to keep open the option of using the West Valley storage pools for storing the solidified waste until it is transported to a permanent disposal site.

Current data do not indicate that the low-level waste burial grounds pose any health hazards, Bateman stated. He added that the disposal of low-level wastes is solely a state concern and that the NRC, not DOE, has ultimate licensing responsibility.

Congressman Lundine told the subcommittee that there are serious questions regarding the suitability of both the spent fuel pool and the low-level waste burial grounds. He said the storage pool has structural weaknesses whlch inake it difficult to rerack or expand the pool to store additional fuel rods and to meet NRC seismic criteria. He noted that water has leached into the lov-level wasto burid sites several times in the past and as recent as last apring.

Lundine wamed the panel that subjecting the curreat agreement botween the state and Federal Goverwment to "quild-pro-quo arrangement" as suggested by GNO would undermine both the credibility of the pollcy-making process on West Valley and Administration efforts to estrblish a national nuclear waste management program. 


\section{STATES URGED TO TAKE LEAD IN LOV-LEVEL VASTE DISPOSAL PROGRAM}

States negotiating cooperatively to select from six to eight reginnal disposal sites for low-level radioactive wastes, in addition to congressional approval of financial "incentives" to such states, would promote the most rapid solution to the nation's low-level waste disposal crisis.

These are among the primary recommendations of the NGA Task Force on Low-Level Radioactive Waste Disposal, chaired by Arizona Gov. Bruce Babbitt. The recommendations were adopted as NGA policy during the association's annual meeting in Denver this week.

The task force report also spells out a process for the development of regions; selection of sites; recommended roles for state and local governments, the federal government and private industry; further research which is needed on the technical issues of low-level waste disposal; and congressional legislation which would authorize states to form compacts and allow those which form regions to exclude out-of-region wastes.

Currently, there are only three commercial waste disposal sites in the nation--at Barnwell, S.C., Beatty, Nev., and Hanford, Wash.

Last year, Washington Gov. Dixy Lee Ray and Nevada Gov. Robert List ordered the sites in their states closed temporarily following the consistent failure of waste generators to properly package and transport their wastes, and the subsequent failure of several federal agencies to adequately enforce waste packaging and transportation regulations and impose proper sanctions.

Additionally, at the Barnwell site, which annually has been receiving over 75 percent of the nation's commercial wastes, South Carolina Gov. Dick Riley has established a drastic phased reduction in the volume of waste accepted at the site. Also, Riley has announced that Barnwell will reject wastes from certain generators with records of poor packaging and shipping practices.

These actions, coupled with the expected increasing volume of waste generated by medical diagnostic and research activities, and military and industrial activities (the nation is expected to generate 321,00 cubic meters of low-level waste by 1990 compared to 99,000 cubic meters in 1980), led to the formation of the task force by the association in December 1979.
The task force recommends that each state accer. primary responsibility for the safe disposal c low-level radioactive waste except for wast generated at federal government facilities.

"Since low-level waste is generated in every state, it is unfair to expect three states to shoulder the sole responsibility for the safe disposal of the nation's waste," the task force report states. "Unlike high-level waste, the problem is not so sechnologically complex that it requires the leadership of the federal government."

A regional approach is favored, according to the report, because, with the exception of a few of the biggest waste generating states, the volume of waste generated in a single state is too small to make operation of a disposal site economical.

The report recommends that Congress autherize the states to enter into interstate compacts to establish regional disposal sites. "Such authorization should include the power to exclude waste generated outside the region from the disposal sites," the report states.

The report also outlines procedures for the formation of regions and for the selection of disposal sites within each region. "A state which is ultimately selected as a regional site can exercise a veto, but as a penalty that state would be required to drop out of that compact... If the vetoing state is denied access to the regiona: site it will have to either find another region which will accept its waste, or make its own arrangenients in-state. The former would be very difficult, and the latter would likely be economically unattractive," according to the report.

The report also outlines incentives which could be used to encourage a state or local community to accept a waste site within its borders.

Such incentives, according to the report, could include a special discretionary fund provided by Congress for use by the site state and site community, a commitment to employ a cortain number of local residents at the waste site, a percentage of revenue generated at the site for the local government, and encouragement for users of the facility to locate near the site.

In addition to Gov. Babbitt, Govs. Bill Clinton of Arkansas, John Evans of Idaho, James Thompson of Illinois, Robert List of Nevada, Dixy Lee Ray of Washington, Dick Riley of South Carolina, and Dich Thornburgh of Peninsylvania served on the tash force. 


\section{S omeone Is Making Money In Nuclear}

The nuclear industry may be up to its neck in problems, but ChemNuclear Systems of Bellevue, Wash., is keepins itself well clear of trouble.

Chem-Nuclear is in the erobase butiness - one of a handfut of com. panies around ithe country offering low-level radiation decontamination services and dispoesl of low-level trash. Where others wateh their markets shrink, Chem-Nuclear ex growth and expansion.

The most reassuring factor in the compan's 's future is the doubling th expects in U.S. nuclear ceners.
tion-to 167 operatins plants by $19 \%$ The company's sales have grown
a a compound annual rate of 73 percent since 1975-from a mere $\$ 3$ mitlion that year $10 \$ 26.6$ million at the end of its 1979 fiscal yetr. For 1980, which ends July J1, analysts predict sales will exceed $\$ \$ 0$ million. One reason is Three Mfile Island. divatier not withoul some keneficiaries. Besides Iransporting nuelear trash to Hanford. Wash. Chem. Nueleat has 51.8 million coniract to design and install a submerged demineralizer system to remove radioactive water from the damaged reactor building. And it is expected to receive follow.on con. traets frem Tisl that enuld amount to between $\$ 10$ million and S1S million, analy'sts say.

Chem-Nuclear's mobile services elso hare blossomed rapidly. Com. pany resident Bruce Johnson, 35.yest-old former public alfairs director for Boein Aerospace, aims to enisrge the neet of vehicles providing mobile solidification and demiraralization senices at nuclear mowet plant sites. From unly litree uhils three years ago, the nest has ernun to 18 today, and Jehnson w ants 10 add two doven more.

Ttie sump.ny alsw will earnet its share ci wark when M. Whatlan Pro. ject ellegincering centers are disin zuiled and as old mislear planis are deconsmissioned orer the net Jecode.

linr the moment, huwever, the priming entite of Chetr. Nuitlear sales his teren ins low.level modicus:

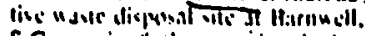

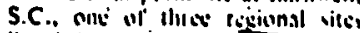

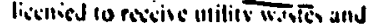

It's Waste To Some, But For Chem-Nuclear, it Means 73 Percent Annual Growth Qr Wilken Cushing. Senrth the. onty site in the eastern U.S. (which produces 90 percent of the waste products from commercil reactors). As might be expected from its locatton, Barnwell. until recently, absorbed up 1080 percent of the nation's low-leved utility wastes.

Last year. however, South Carolina governor Richard Riley cut the burial rate at Barnwell to a max. imum of 100,000 cubie feet per month by Oclober 1981-halving the volume the site receives. Bu Chem-Nucleat fated better than its competilor, Loutsville-based Nuclear Engineering Co. Inc. whose disposal site at Bealty. Nev.. was denied a new permit early las month. NECO also operates month. NECO also operates disporal sile on the federal reserva. tion at Hanford.

New higher disposal fees will help to mitigate. iorses from reduced burials at Barnwell. which-even with the resirictions - could operate for snother 25.35 jears. says chief executive Johnson. The company owns another 40 acres that fit into the site which, if licensed, would further extend Barnwell's life.

And Johnson is not worried aboul further restrictions. "I see no problem with our punning site In South Carolina," he says. "The question is wate action will the saces and the federal governmient lake if fother cristingl sites are restricted. If. in the liexi two or lilese sears. niher regional sites are omened. the problem will go away. Bill Barnwelt cannm continue as the only major-low-level radioactive [burial] sile."

Relievine the pressure won't be easy. The provess of identifyius and developiurs niw revional sites won'i meve illesd unit the Nucleas Reguldiory Cominiesion devilups critcria for handting low-level rad. wate, Johnson bolieves. But ChemNucles won't risk another venture itke 1978, when it pursued another site on its own. That yent, the company was forced to drop its efforts to obtain a license for a storage and disposal site in Cimmuron. N.M., and had to write off more thao 5700,000 in developthent coses.

Still fuming. Johneon critlcizes current NRC slte. development criteria-requiring selection of the best one of ihree (expensively) iden. lified sites-as "pointless and ridiculous, particularly if you expect ridiculous, particularly if yod

What about potential locations? Chem-Nuclear has been discussing possible sites with ofricials in severd states, but Johnson won't tip his hand about location until he has ite under option. He says, however. that thete are good possibilities in New Mexico, Pennsylvania, Virginie and New York. The West Valley site, south of Buffalo and closed by New York in the early. 1970s, "could and should be onen. "." he says. "It's very 'lis's veod lechnically - hydrologically and geologically."

In total. five to eighe regional sites would be sufficient to handle the na. tion's low-level nuclear wastes. Johnson believes. More than that would raise costs, he says, because of the duplication of fixed costs-such as health physicists. quality assurance people, lab technicians and equipment oposalors -at each sile.

The politican proolems associated with waste repository siting won't be sided much by advanced methods of redueins the volume of waste, Johnson believes. "States are just concerned with havine 10 lake lots of waste from other states." If on-site storage becomes feasi. ble firms like Chem-Vuclear would poekne the waste coniruct the package the waste, construct the

needed racilities and manuge thein. Despite the company's rovy future as a nuelear waste hindilcr. the "Chem" in its name shortly wil assume greater prominence. Alihough nutclear operistions niscount loir 65 percent of its busincss. the Revuurce Recovery and conser. vation $A$ at will bone tes chetriciols handling busiucss, tientually mak.
Malrine Monor in Nuclese (Continued from precedine poses) ing th a larget eapner.

The ect, which mandales sirtetes criterin for handling chemleal and oihet hemedous wastes produced by industry, offers colden oppor. tunities for a company with Chem. Nuclear'i ergerience. The company operates on chemical Atspond sle clirendy at Arlinglon in enter. Orepon and ls ponderias at least on other in the eautern U.S. Say Johnson: "The market there is wo much biger...If the just maintain out matket thase we'll do pretty good."

In late July, nowever, the com. pany's bourd of directors bilked at outhorizine a now stock lasue to rise money to scauire now site. But few expect this enersetle com Bur few expect inh enercets com. 


\section{July 24,1980}

THE FUTURE OF THE HANFORD, WASH., NUCLEAR DUMP SITE MAY BE DECTUEU this November in a voter initiative, if the Washington secretary of state. determines that enough valid signatures have been sub. mitted to put the measure on the ballot. If passed by the voters, the initiative would block the importation of nuclear waste into Washington for temporary or permanent storage, with the exception of waste generated by medical aetivity. The ben vould take effect July 1.1981. The initiative would also allow Washington to ecept waste from states with which it maj: enter into regional storage agreements.

Supporters of the initiative say they are attempting to prevent the state from becoming the nation's "nuclear dump sitc." A spokesman for Don't Waste Washingion, the organization behind the initiative, said that the group "wants to send a clear inessage to. Washington. D.C.. that the people of this state are not"exactby eaget to take all the waste that President Carter would like to send them because of other site closings or tonghening anitudes in South Caculina and otheridump sites."

A source at Nuiluar Engineerint Co, (Nevo), which operates the Hanford burial site, denied that Wishington "lias ever been the dumping frosund oi the nation for nuclear wiastc." Neco, the suurce said, plans to conduct "a public information and education cffort" to fight the initiative. "We want to allay the fears caused by the emotional efforts of the other side." the Neco smurce said. "We believe the site poses no safety problems. and that it nrects an esuential need." Neco's operation of its ollicr waste disposal site. at.Beatly, Nev.. Would not be affeited by the outione of the W'ashingtun vote.

The Dem't Waste Hashingtun spukesmin said one of the purposes of the initiative, win or lose, is to "ytimulate discussion about the idea of reginaal sites." The spokesman said, "Undoubtedly, there are other adequate sites around the U.S." A Washington regional site, he said, would "probably not" extend any farther than the surrounding states of Oregon, Montana and Idaho.

Tho Neco source responded. "While we recopnize the political nerestity at establishing regionil citem the Iuty I cutolf date is unrealistic. Imterstate compacts require that identical legislation be passed by all states concerned: There mest atso be approval by Congress. Only then can site selection, environmental impact studine, rogulatery requincment selliuys and the secesury public hearings begin. The whole process could: talio 5 -8 years."

The initiative, commonly known as 383, after its filing number, may also pose difficult legal questions if pasied The Neco spokesman asked rbetorically. "Is the waste generated from the out-of state manufacture of smoke detectors used in Washington acturlly out-of-state kaste? And is the waste produced from the inanu. facture of radioactive medicines in Connecticut actually Comnecticut waste; or is it Washington waste if the: medictnes are.used in. Washington? Also, is waste generated out-of-state for the production of electricity used in. Washington th-state or out:-of-state waste?"' Initintive supporters tond to apply the strictest definition pos. Hblo to 383; but are williog to await court decisions on such matters.

Sueh concerns, howover, may be prematuse. While the inithtive petizions seemingly were filed with a sufnicient number of signatures to put the measure on the ballot, each signature must undergo scrutiny by the secretary of state in order to determine its validity. Only voters who voted in the last election for gover: nos of Washington are eligible to sign; and $8 \%$ of those peopie - or 123,711 voters - must sign the petition. A tomi of 148,20r signatures were filed, leaving a margin of $16.5 \%$. According to a source in the sectetary of state's office, thoogh, the rate of invalid sigastures is running "at about $16 \%$." While a final tally will not be antived at for about four weeks, the source said, "whether the initiative gots on the ballot or not is anybody's guess at this point." Historically, Washington initiatives run an $8 \%-12 \%$ invalid signature rate, but in tho case

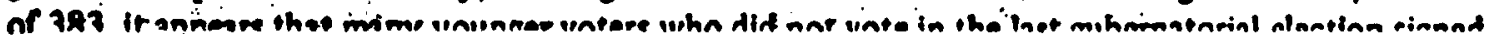




\section{NRC SETTING OUT TO ANSWER, WHAT IS LOW-LEVEL WASTE?'}

NRC is in the process of climinating low-lcvel waste - not in fact but in definition. What will result from this undertaking is a set of criteria guiding NRC and applicants for waste disposal site licenses in dealiny with the broad spectrum of radioxetive waste long characterioed as low level. The NRC strategy essentially is so characterice waste inaterial by the means available for dispusing of it. and one peactical effect may be the establishincit of burial sites reserved for specific types of waste sourics. such as nucleat plants on the onte hand and niedical and resciarsh facilities on the other.

"Toliay we l!aie the authority to license bul we don't have the critcria," said an NRC source. noting that the 10 CFR 50 appendix F defines only high-level waste (as the solsent material left over from reprosessing) and that all odher waste is cunsidered low level. This lack of distinction has become particularly troublesome in the last yeat or sn as the three states containing the only U.S. Low fevel waste burial grounds have ex. pressed cuncern that relstively high levels of lonig-lited materials sre being dumped at the sites.

This complaint is only one ammong many voiced by South Carolina. Washington and Nivada as they make out-of-state aciess to the favilicies more difficult. The result has been increased state and federal attention un the need lier adlitional siles, and .NRC's realization that it lacks a suificiently formali/ed licensing process. The NRC sourie suid. "Wie're tryitig to do two things: head oft somplaints that there aren't any rilis to the game. and we want to specid up licillsing."

NIiC hiss thece perfonnince ohjectives guiding establislment of low-level waste site criteria: that the site mot icyuite active mainemame tore more than 100 years: that the accident ind intuder be proteited: and

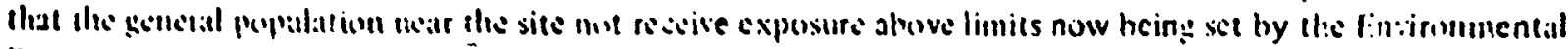

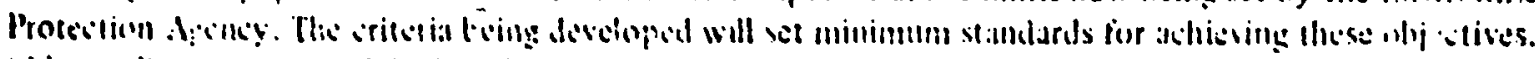

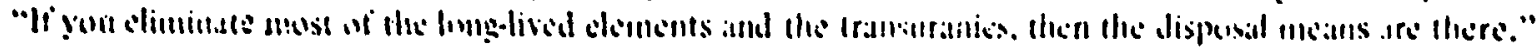

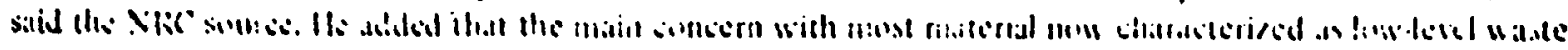

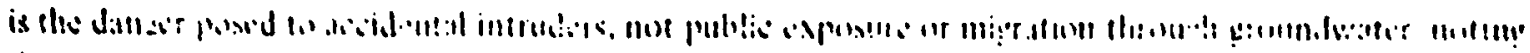

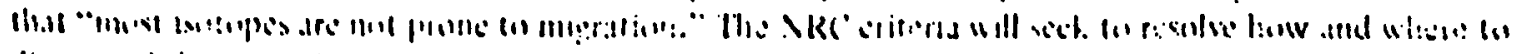

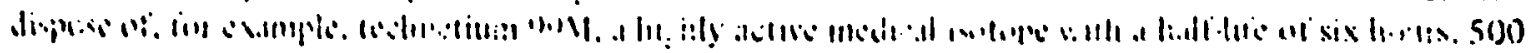
longer half.taie and cannot be devil with as casily as the inedical isotespe, which can be stored and then disposed of after it? activily has decrubicd.

NRC's schedule calls for derelupment of criteria to be completed by April 1981. to be followed hy abrist a nn:-ye-1! rulemakin?. Licst: se spplieution! in the meantime, however. will be dealt with under guide-

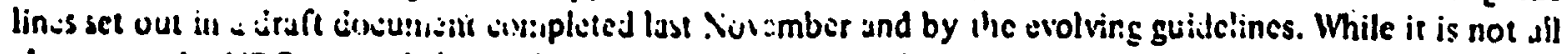
clear nou: the NRC source balieves the new rule may lead to the segregation of wiste by source and, sirnilar to the thinking of a DOE low-Jevel waste task force, that less active waste would be managed by the states while more aitive material would cisme under federal authority.

NKC has no low-level waste site lisense applisations pending. As one suurce noted. industry is loash to reveal plans fort a speciili ste in advance of actualiy applying for a license because of the likelihuod of public opposition. As for the statis. Virgiria appears to be moving about as quickls as any other in pursuing the pussibility ui establishing a new disposal facility. - Rob Laufer 
Apr. 25, 1980

\section{Nuclear Enorov}

\section{GAO RECOMMENDS LICENSING MOAATORIUM ON NEW LOW-LEVEL WASTE BUAIAL SITES}

The General Accounting Office March $\mathbf{3 1}$ recommended that a moratorium be imposed on the licensing of new low-level radioactive waste shallow land burial sites until the Department of Energy completes its national plan for the disposal of low-level wastes.

The plan. directed by President Carter in his February announcement of a national nuclear waste management program (Current Development. February 15, p. 1990), is expected to be completed by June 1881.

DOE and the Nuclear Regulatory Commission, which has licensing authority for low-level disposal sites, disagree with the GAO recommendation because they say it would hinder states in their development of new shallow land burial sites, as well as cause states to expect the Federal Government to solve the low level waste disposal problems.

The GAO study was requested by Congressman John $D$. Dingell (D-Mich), chairman of the House Interstate and Foreign Commerce Subcommittee on Energy and Power, to identify problems associated with low-level waste disposal, to determine responsibility for resolving the problems, and to evaluate the progress of Federal Government to resolve the problems.

Both NRC and DOE have made it clear to Congress that commercial disposal sites should be the responsibility of the states and not the Federal Government (November 16, 1979, p. 1524). In addition, the governors of the three states Washington, Nevada, South Carolina - which currently have operating low-level waste disposal sites have called on all states 10 assume responsibility for their own Jow-level wastes (November 9, 1979 p. 1510).

In a separate but related study, GAO recommended that existing reactor sites be used to store and in some cases per. manently dispose of low-level wastes. (See related story, p. 2340).
Recommendations

In the short term. GAO said NRC can alleviate the present disposal problem if its acts promptly in considering several basic questions. These questions are:

- What is low-level waste:

- Who are the generators of low-level waste and how much waste do they generate:

- Can the volume of low-level waste be reduced; and

- Is illegal dumping of low-level waste occurring?

With respect to the low-level waste management plan being developed by DOE, GAO said DOE should work with other federal agencies to assess the number, type. and general location of waste disposal sites that would be needed on a regional basis. In addition, GAO recommended that DOE define the federal versus state responsibility for low-level waste disposal: evaluate the feasibility of using existing DOE facilities for disposal of commercial wastes. and investigate the possibility of reopening the three closed commercial sites.

\section{Contingency Plan to Use DOE Sites}

Earlier. DOE issued a draft of its contingency plan stipulating steps NRC would have to follow in order to use DOE facilities for commercial low-level wastes disposal (October 12, 1979, p. 1355).

DOE said it is in the process of completing an environmer. tal assessment of the contingency plan before it is finalized.

National Disposal Plan
In anticipation of the President's announcement in February, DOF, initiated a national strategy document last summer and currently is preparing a full draft of the document which is expected to be released for public comment in July.

The strategy is based on South Carolina's recent action to limit the annual volume of waste accepted by the Barnwel! site: It assumes that in $\mathbf{1 9 8 2}$ the Handford sites will not be accepting out-of-state wastes: it divides the country into the Northwest. Southwest, South. Northenst, and Midwest regions. and it defines a shallow-land burial site as having an operational life of $\mathbf{4 0}$ years and an annual capacity of about 1.2 million cubic feet.

Based on these assumptions, it is projected that a total of 2.25 additional sites will be required in $1880 ; 2.50$ sites in 1982: 3.50 in 1984: 4.50 in 1986: 5.25 in 1988: and 6 ad. ditional sites by 1990 .

\section{Availability}

Single copies of the report. "The Problem of Disposing of Nuclear Low-Level Waste: Where Do We Go From Here?" EMID-8R-68. are available tree of charge from GAO. Distribution Section. Fonm 1518. 441 G St.. NK: Hashington. D.C. 


\section{MAXIMUM NUMBER OF NUCLEAR UNITS OPERATING BY 2000, NRC PANEL SAYS}

The maximum number of nuclear units that could be uperaung in the U.S. Jy the end oi the sentury

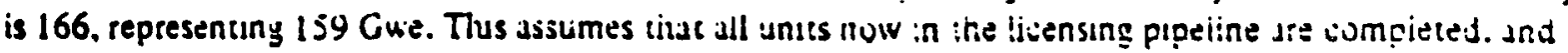
is 99 units more than those currently iicensed to uperate. li inise that do not yet have cunstrucison permits drop out there will be 155 untes ( $1+6 \mathrm{G}$ we I upetating in $: 000$. li :'iose units that have a construction permit but have not yet poured toncrete are removed irom the list the number ot unis operaung by 2000 would be 135-1 10 .

These are projections drawn up by the XRC euseload panel, winich ionsists vi seven statiers drawn irom various offices. The panel develops caseload projecuuns tor.use by the staif in budget preparation and lunger. range program planuing. Specitic workload and manpower loadings jased on the projections are developed by individual NRC offices. The projections in the panel's lacest repurt (for FY-82-36) are ossed primanily on surveys of industry plans by the oticices of nuslear reactor reguiation and nuclear material satety $\&$ satezuards.

The report says that the tune from CP applisation to cummercial uperation of a large reactor in the 1983-84 period "is, based un historical trends. expected to be sbout 15.16 years: thus any reactor application tendered after that time would not be expected to be in commervial uperation by the year $2000 . "$

In order to be operating by 2000 a utility would have to apply for a CP by mid-1984, sald an NRC staffer, and that would mean placing an order tor the unit by mid-1992. "We don't see a large turnaround in order rate by then." sald the orticial. DOE and the reactor vendurs are talking oi possible orders in 1983 or '84. This would mean an applisation tor a construction permit in 1985 or ' 36 and - allowing tor the 15 16-year licensing process - the unit would not be in commercial operation until arter the turn of the sentury. allowing a year for reaching commercial operation atter $O L$ issuance, the statfer said.

NRC believes that by 1985 there will be 113 units $(98 \mathrm{G}$ (ve) in commercial operation, including the present 67 licensed to uperate. Toward the end of 1986 ihere are expected to be abuut 135 teactors (1:4 Gwe) operating or ready for ruel loading. Only one new CP appiication is expected to come in during the early to mid-1980s the unly plant currenty on order ror which a CP has nut been southe is Commonwealth Edison's proposed Carroll County-1 and -2). Sume $2-8$ applications for OLs per year will be tendered to NRC during that period, the pand report says.

NRC expects DOE to apply for a high-level waste repository license by 1987 and NRC will be conducting site-characterization reviews in a variety of media throughout FY.81-86. Four additional away. irom:reactor spent fuel storage iacilities are expected to be ticensed during FY.82-86, meering.a demand of about 5,000 inetric tons by about FY.83.

By FY.86 there are expected to be 23 fuel cycle facilities under NRC licensing authority and about 10,500 radioisuiope licenses. There will be up to nine licensed sites for luw level wastes (including the three currently licensed sites - Barnwell, Beatty and Hantord). and NRC assistance on six other sites will be provided to agreeinent states, the panel forecasts.

Soine 34 licensed uraniuin mills and abuut 70 additional licenses for other types of activities. such as solution mining and ure buying. are expected by FY.86. Transportation reviews will average abuut 55 par year throughout FY.82.\$0 and $300-400$ shipments of eadivilctive material per year will require a sateguards review and will be monitured in transit. the paltel says. Abous $\$ 00$ material control and accounting reviews and about 500 pliysical sceurity reviews tur vapious tual cycle fisilities, power and nunpuwer reacturs will be required each year.

Export and import licenscs will average about 1.000 reviews per year throughtsut FY.82.86. About 15\% are designated major ciascs sequiring cummission approval and allollice $15.20 \%$ require safeguarcis re. views, llic pantel repurts. 


\section{DOE PROPOSES EACH STATE IDENTIFY SITE FOR LOW-LEVEL NUCLEAR WASTE DISPOSAL}

A DOE document detailing an approsch for states to establish new regional low-level nuclear waste burial grounds recommends that each of the 50 states and the District Columbia be required to identify, characterize and possibly select a site for much burial grounds within its borders within specific time frames to be determined by Congress.

The document, which DOE sent last week to Rep. Mike McCormack, chairman of the House Science and Technology nucleat subcommittee, recommends this process begin as soon as the Nuclear Regulatory Commission establishes site selection criteria and Congress passes legislation giving states financial assistance, if necessary, and the authority to manage wastes on a regional basis.

Six to eight new sites needed. Six to eight new burial grounds will be needed reginnally thrnughnut the next decade, according to the DOE document. These sites should be established by regional groups of states or on a state-by-state basis, according to the DOE document, which advocated, however, that all states be involved in looking for suitable sites. The first of the six to eight sites, the document suggests, should be established as soon as possible in the Northeast and Midwest, where most of the waste is now generated, with remain. ing sites to be established regionally at one to two year intervals throughout the 1980 s.

In strongly supporting the concept of regional sites, DOE said that shipping wastes long distances was "undesirable" because of increased costs and risk of accidents. Some eastern utilities are currently forced to ship wastes to burial grounds at Beatty, Nev., or Richland, Wash., because volume restrictions were imposed by South Carolina officials at the only other operating burial ground, at Barnwell, S.C. Legislation would be required for burial grounds established by regional groups of states, DOE officials said, to give the states the authority to refuse to take wastes at the site from outside the region.

DOE will take wastes in an emergency. The DOE document estimated it will take states "at least two years" to establish a burial ground and said that if an immediate need for disposal space emerged before new sites could begin operating, states should find interim storage facilities and take action to minimize waste generation and waste volumes ready for disposal. If interim storage could not be found, the document said, DOE would consider taking commercial wastes on an interim basis at its sites in states where governors would not object after NRC declared a state of emergency.

The document made the following additional recommendations and points:

- Establishment of regional sites should be a state responsibility, and DOE's role should be limited to pro. viding technical planning and assistance.

- States should be allowed to co-locate nuclear waste sites with sites for other types of hazardous waste "where appropriate."

- Technology should be developed and implemented to reduce the volume of waste and provide alternatives to shallow land burial.

- States may need unrestricted federal grants for low level waste management.

- States should "be free" to collect "reasonable" waste disposal charges but should be prohibited from collecting charges for a perpetual care fund from institutions generating wastes with short-lived radioactivity.

- Twenty-four states generate low-tevel nuclear wastes from commercial power reactors and all 50 states and the District of Columbia generate both institutional and industrial low level nuclear waste.

- Nevada, South Carolina, and Washington, states where the only operating burial grounds are located, received $11 \%, 75 \%$ and $10 \%$ of the commercial waste generated in 1978 but facilities in those states generated only $2 \%, 6 \%$ and $1.5 \%$ (respectively) of that waste.

- Of the top 10 waste generating states - South Carolina, New York, Califomia, Ilinois, North Carolina, Pennsylvania, Florida, Massachusetts, Connecticut and Michigan - only South Carolina has an operating burial ground for disposal of such waste.

DOE comprehensive warte plan due in May. DOE officials said that the siting approach outlined in the document would be included in a comprehensive plan for low-level waste management to be released by the department in May, in response to a recommendation by the Interagency Review Group on waste management and a proposal in the House version of the FY-80 DOE authorization bill pending in Congress. Rep. McComack asked DOE in October to immediately draw up plans for siting new burial grounds after afety concerns led to the shutdown of all but the Bamwell, S.C., burial ground. 


\section{S. CAROLINA OFFICIALS SEEK TO RESTRICT DOE USE OF BARNWELL PLANT AS AFR}

The South Carolina state legislature within the next several weeks will seek to prevent or delay DOE from establishing an away-from-reactor (AFR) nuclear spent fuel storage facility at Allied-General Nuclear Services' defunct reprocessing plant in Bamwell, S.C., according to state sources. DOE officials recently said they would like to rerack and license the Bamwell site to begin taking AFR spent fuel in 1984-85 (see related story, page 3).

According to state sources, two joint resolutions separately proposed in the legislature - one of which is expected to be approved in some form during the current legislative session - would make DOE use uf the Barnwell plant as an AFR contingent on a two-thirds approval by the legislature or on substantial DOE progress in developing a high-level waste repository. Both proposals, said state sources, could restrict DOE actions to use the Barnwell site.

State legislators are showing strong support for the resolutions, state sources said, because they believe both of the proposals would prevent Barnwell from becoming a long-term AFR or the only such plant in the country by requiring DOE to develop a repository for disposal and other AFRs. State officials believe, sources said, that federal inaction on the waste program, in part, has been the cause of the state's having to take an unfair share of low-level waste at the Barnwell burial ground. State officials also cite lack of federa! action for delays in solidification and disposal of high-level nuclear waste that has accumulated at DOE's Savannah River plant.

One of the joint resolutions, proposed by 41 state representatives, calls for the President and Congress to prohibit use of Barnwell as an AFR unless it is approved by a twothirds majority of the South Carolina legislature and the governor. State sources said it would be extremely difficult to get two thirds of the state legislature to approve anything.

Another joint reolution proposed in the state Senate would link AFR storage at Barnwell to development of a disponl facility and is considered almost as restrictive as the House proposal, according to state sources. The Senate resolution urges the South Carolina congressional delegation to seek to amend any federal Barnwell-AFR legislation to guarantee that: 1. DOE will mandate interim spent fuel storage regionally throughout the US.; 2. South Carolina officials will be able to participate in all environmental and safety reviews of the Barnwell plant as an AFR; 3 . spent fuel will be removed from the AFR for disposal after 3 40-year storage period; 4. spent fuel stored at the AFR will be transported after 40 years of storage to an offsite "long-term dry retrievable surface storage facility" if a repository is not available: and 5. no AFR will be established at the Barnwell complex until DOE "obtains agreements from the legislatures and govemors of host states that ... [repository] sites may be explored and developed."

The fifth condition of the resolution is the most likely to delay use of the Bamwell as an AFR, according to state and DOE officials. Sources expect that DOE will have trouble getting states to agree to allow "development" of a high-level waste repository within their borders. given the difficulty DOE has had getting the states to agree to allow first-step exploration of candidate geologic media.

Sources also believe that a soon-tobe-announced presidential nuclear waste policy decision could further hinder DOE in seeking agreements for development of repository sites. In that decision, President Carter will delay DOE selection of repository sites until after DOE has qualified $4-5$ potential sites in various geologic media and environments, according to DOE sources. This delay would push DOE site selection to 1984-85, and some sources are concerned that DOE could not obtain agreements from states for development of a site until then. But one DOE official said this week that DOE can sign such agreements with states any time before sites are officially selected. 
Oct. 22, 1979

\section{Nuclear Wastes}

\section{S.C.'s Riley Pushes A Debate}

South Carolina's Gov. Dick Riley is going to fool around with nuclear wastes until he starts a real discussion. Good. Carolinians will be wiser for it.

Events in South Carolina last week suggest that the nation's leaders - in government and the nuclear industry are likely to be drawn into the debate. The result could be a clear national policy on nuclear wastes, an achievement Gov. Riley could be proud of helping to bring about.

Right now, not even scientists can agree how to manage wastes, how dangerous they are or even how long they must be isolated from people and the en. vironment. But they agree that wastes present a problem requiring special care.

Essentially, that's what the discussion in South Carolina was about: how careful the nuclear industry must be in disposing of wastes, and how much the government must spend to assure that wastes are disposed of properly.

Early last week. Gov. Riley forbade an Illinois firm from sending more lowlevel nuclear wastes to South Carolina for disposal. He said the company has a history of sloppy waste shipments, and the ban.would demonstrate the tough approach he is taking with a nuclear industry previous state offlcials had courted.

But later in the week, state nfficlals acknowledged they had stopped full-time inspection of waste shipments to the state's burial site at Chem-Nuclear Systems Inc. near Barnwell. Regular state inspections were begun last April, shortly after the accident at Three Mile Island. They were stopped because there weren't enough inspectors to monitor the site six days a week, from 7 a.m. until 6 p.m.

David Reid, Gov. Riley's energy aide, acknowledged Friday that the less frequent schedule of inspections could be unsettling. But he said Gov. Riley's ban early in the week was aimed at a company which had not lived by the rules.

That isn't the case with Chem-Nuclear, which inspects every shipment It, accepts, he said. The state's periodic inspections will ensure that Chem-Nuclear also continues to live by the rules. But right now, officials have no problems with the company. "If we did. we'd shut them down," he said.

But the problem brings home a debate rising nationwide over how much inspection is needed and who should provide it. To that end, Gov. Riley and the governors of Nevada and Washington ivill meet with experts at the Nuclear Regulatory Commission. Nov. 6 to press for federal commitments to work with the three states now handling all the nation's lowlevel wastes. Let the debate continue. 
Aug. 14, 1979

NRC ISŚUES BULLETINS TO iICENSEES

ON PACRAGIMG OP LOW-LEVEL WASTES

\begin{abstract}
The Nuclear Requlatory Commission nas lasued bulleting to all 8,000 of lts licensees directing those that generate lowlovel radionctive waste to take certain actions to ensuce that the wates w111 be properly packaged for transport to tiuriel sites in three states.

Governors of the three states with operating low-level waste burial iltes--Nevada, South Caroline and Wainington-have expresied concern about enforcement of rulas governing pockaging and transportetion of these wastes. The NRC action. i. In respante to those concerns.

Locatione and operators of the sites are Barnwell, SC, Chern-Nuclear syoteme, Inc., and Bectty, NV, and Manford, WA Nuclear Engineering Company. Inc.

Problems that have occurred include contamination, leaking. improperly loaded and improperly labeled packages. This has lod to Incidente such is fire and contamination of vehicles.

Out of is inspment of low-levil wates to the Barnuell facilley, 63 deflelencies vere observed by the state of South carolina during a packago inspection progran from April 10, 1979 to July 5, 1979. The shipments were from reactor, medical; Induetrial and military facilitios.
\end{abstract}

The ARC etaft warned that Governora of the three stated with licenged burial facilities have indicated that, It the oltution is not ractifled, they may have to initlate actions that would deny ue of the three burlal ates by violators.

"nter the NRC directive, ifferted HRC Ileensees must

(1) Maintain a current set of NRC, Departmant of Traneportation and state regulations and requiremente involving traneter. Deckeging and eranoprt detivities for low-lovel. wateve:

(2) vedignate persons in thedx organizetion who ere renponsible for these activities!

(3) Provide detailed Instructione and operating proceaures to oll personnel lnvolved in these ectivlties:

(4) Provida trainting and periodic retraining to personnel involved in these cctivities to keop them aware of regulatory and waste burial licenee requirements and to ensure thet the volune of waste to minimized and is procesaed into acceptable cherical and phyaleal fore for anipment to the burial ites and

(5) Establish a managiment-controlled audst functlon tor - 11 transfar. packaging and transport activities, with the firse audie to be performed within 60 .daye of the NRC bulletins. 
The Nuclear Regulatory Commission (NRC) directed those of its 8,000 licensees that generate low-level radioactive wastes to take steps to ensure that wastes arepactaged properly for transport to burial sites in three states and to begin management-controlled audits on those steps.

The action was taken in response to concerns expressed by governurs of the three states where burial sites are operated. The sites are located at Barnwell, S.C.; Beatty. Nev.; and Hanford, Wash.

Governors Robert List of Nevada, Richard Riley of South Carolina, and Dixy Lee Ray of Washington July 10 demanded of then-Transportation Secretary Brock Adams and NRC Chairman Chairman Joseph Hendri that the packaging and shipment of waste materials be "drastically improved."

The governors explained that their action was prompted by "serious and repeated disregard for evisting rules governing the shipments of commercially generated low-level nuclear wastes and the total lack of corrective measures by the NRC." They said a new flan. "must bo submitted by the tederal agencies no later than August 1, 1979" and must go into effect one month later. Such a plan "must include the following components:"

- Dispatch of a trained team of inspectors to perform regular site inspections of both the source generators and the collectors of nuclear waste. The inspections must include the opening of containers.

- Provide detailed instructions and operating procedures to all personnel involved in such activities.

- Provide training and periodic retraining to personnel involved to keep them aware of regulatory and waste burial license requirements and to ensure that the volume of waste is minimized and is processed into acceptable chemical and physical form for shipment to the burial site.

- Establish a management-controlled audit function for all transfer. packaging, and transport activities, with the first audit to be performed within 60 days of receipt of the bulletin. 
Oct. 11, 1979

Nuclear Energy

GOVERNOR CLOSES HANFORD, WASHINGTON. STORAGE FACILITY FOR RADIOACTIVE WASTE

A privately operated facility for the storage of -low-level radioactive waste was closed October 4 by Washington Governor Dixy Lee Ray.

Her action stemmed from the fact that seven out of nine tr'sckloads entering the state in the previous three days were "found to have equipment defects or radiological defects," an aide to the Governor said. Another state official told EUR October 5. "It is really not a health and safety issue so much as a packaging issue and a matter of principle."

In July, Ray, along with the governors of Nevada and South Carolina, demanded of the Nuclear Regulatory Commission and the Department of Transportation that the packaging and transport of waste materials be "drastically improved" ( 315 EUR 13).

South Carolina receives 80 percent of all U.S. low-level waste, with Washington and Nevada accounting for the other 20 percent. The waste includes used uniforms and supplies, primarily from medical and educational institutions. About 200,000 cubic feet of such waste was stored by Nuclear Engineering Company at Hanford last year.

An aide to Ray told EUR October 5 that NRC Chairman Joseph Hendrie and the governor had spoken. He concurred in her action and said, "the ball is in our court now." Hendrie told Ray that NRC would notify all licensees of the action and would set to work immediately with the Department of Transportation on another review of procedures.

He agreed with Ray's comment that "the NRC staff is too busy with 'what ifs' and testifying to Congress to try to take care of regular routine work."

The governors of the three states earlier agreed that if one state refuses entry, the other two also would refuse to receive the alfected material. 


\section{REGIONAL LOIN.LEVEL WASTE BILL DRAFTED; HANFORD CLOSED, BEATTY THREATENED}

While one of three U.S. low-level nuclear waste sites was shut down last week and another was being Urreatened with closing this week, legislation is bsing readicd in Washington to create about a dozen regional facilities to handle the nation's increasing load of low-level waste.

The bill is being drafted by the staff of Rep. Mike McCorniack (D.Nash.). Although still in the drafting stage, the bill will aim to mitie the U.S. regionally self-sufficicut in low-level wastc disposal, a concept voiced with growing schemence by Wushingt on Gur. Dixy Lee Ray who last Thursda! (Oct. 4) closed the Hinford, Wash., burial ground hecause of leaking shipments and defective vehicles. Ray, who asked her staic's congression:al delegation to push for a nativunal solution to the low-level waste problem, has been a strong critic of those statis which are bloch ing disposal within their borders.

As it stands now. the Mi.Cormack hill would require states to provide land for disposal factities on a re-

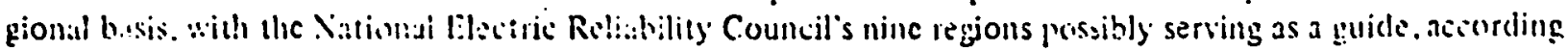
to suntics.

Other features of lle hill are likely w include charging DOE with respunsibility for perfecting incinteration

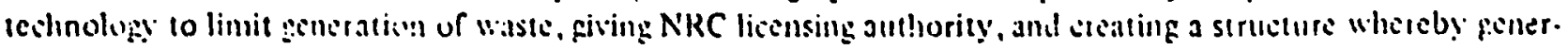

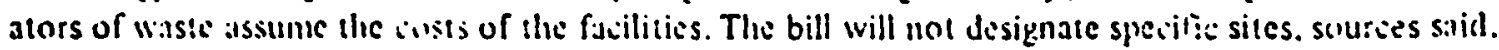

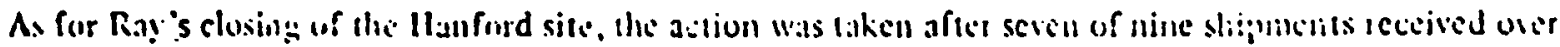

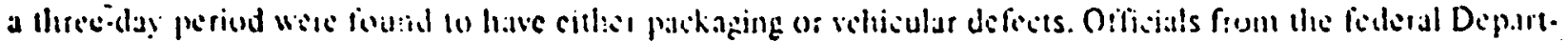

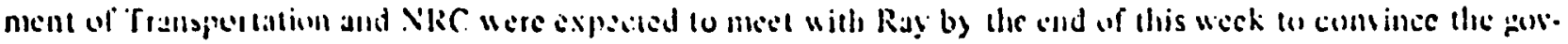

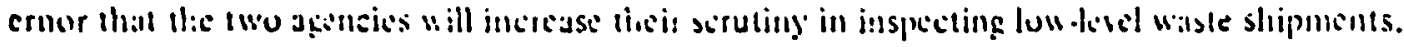

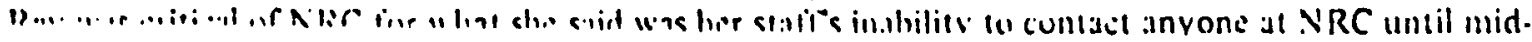

night last licinesday (Uct. s) alter huurs ul iepejted calls. NRC chairman Joseph Hendrie, meanwhile, told Ray he cuncurred with her action in closing the llanford site.

Ray perinitted all shipments in tansit at the time of the shutdown to complete ineir journey to Hanford. However, the governors of South Carolina and Nevada, the other states with operating low-level waste facilities, said they would prohibit stipinents ordinari!y intended for Hanford.

A spokesman for N'uclear Engincering Co.. which operates the Hanford and Beatty, Nev. sites, said some 30 shipnients regularly recejied at Ha:? furd each weck would therefore be denied any hurial space. Continuition of this situation could threaten the nperation of sone facilities, such as hospitals, which generate low-derel waste, the snoizesman said.

The picture is further inudulled by a tomporary restraining order being soukbl by a newspaper, the Las Vegas Sun, to cluse Vico's Beatly operatiou beciuse of alleged mismanagemant there and at othes fucilitles Neco has cierated. Thic restraining orúcr, stheduled to be rulsd on by a federal District Coult judge this week, follows a suit brought by the newspaper to permanently shut down the facility. A source at the newspaper said it is purswing the action becususe "our responsibility coes hiv'ond editorializing." Neco denics all charges brought in the suit.

The Beatty site is also being threatened by the state, which clnsed it for screral weeks in July afte leak. ing shipments we re discoicred. A hearing is scicduled in Carson City, Nev., Nov. 28 by the state Board of Healih on continuation of Necn's license in uigerate the facility. - Rob Loufcr 
NUCLEONICS WEEK

Oct. 18,1979

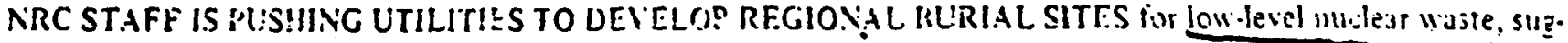
gesting that there could be cclliestive action fur both the construction and opers:ion of such tectitise. The staff also p! ans to publish p:opersed draft criteria for low-level w:ste disposal in an early notice of rulomaking in the next two munths - monthis estlier than uriginally expected.

NRC :hus is trying to cisicurne waste dispcisal problems which rapidily are assuming crisis proportions. Washinglon Gov. Dixy Lee Ray recintly closed down the Hanfurt burial grciund becuuse of slopjy shipment practices. The Eeatty, Ner.. sitc has been tiresaiefied with shoudewn by officials of that state. And highei dis-

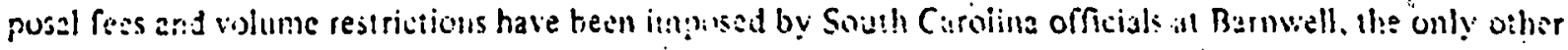
turial sice in the U.S.

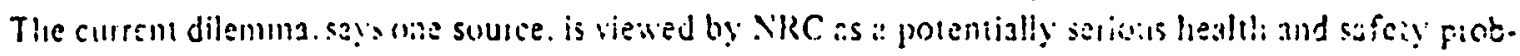

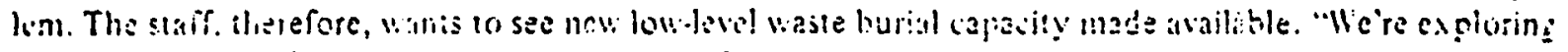

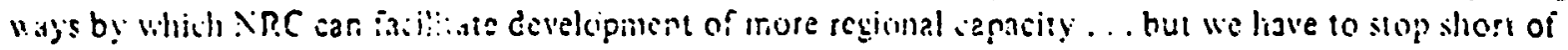

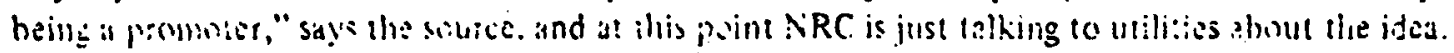

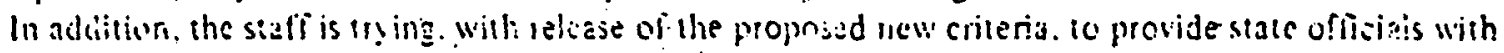

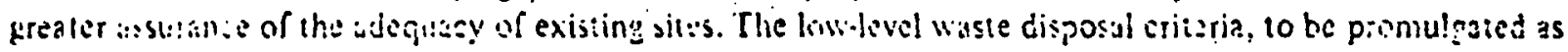

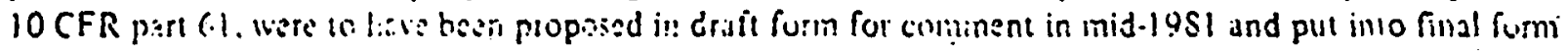

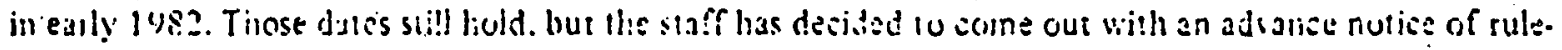
m:2!:ing lo give prospeclive !:2: site ownets snj operators an id:a of what NRC will be expecting. 


\section{WASHINGTON GOVERNOR MEETS WITH NRC, DOT TO DISCUSS WASTE DISPOSAL SITE SHUTDOWN}

SEATTLE. Wash., - (By an Environment Reporter staft zorrespondent) - Washington Governor Dixy Lee Ray October 16 met with officials from the Nuclear Regulatory Commission and the Department of Transportation to discuss her closure two weeks ago of the nuclear waste disposal site on the Hanford reservation.

Ray shut down the site when state and federal inspectors discovered three out-of-state trucks carrying low-level nuclear wastes to Hanford had defective equipment or Teaking containers (Current Developments, October 12, p. 1352).

In discussions with NRC and DOT officials this week on how to get the disposal site reopened, Ray said she would meet again with the agencies November 6 to present a proposal - from the three states that receive commercially generated wastes - to improve safeguards for shipping wastes:

According to Anna Peterson, assistant press secretary to the governor, Governors Ray, Robert List of Nevada, and Richard W. Riley of South Carolina, will suggest to NRC and DOT that all states sending low-level wastes beyond their borders to those three states be required to certify the safety of the waste packaging.

The states would have to share responsibility for the packaging under the state certification program, Peterson October 16 told Environment Reporter.

Very few states now have such certified agreements with the receiving states. she said.

The Hanford disposal site will remain closed until at least the November meeting, according to Peterson. In the meanvime, NRC and DOT are expected to develop specific safeguards for shipping of low-level radioactive wastes. The agencies have already agreed to increase inspections to make sure that shippers are packaging the materials properly at the generating site, Peterson said

The meeting between Ray and federal officisls was basically informational. she said. Also attending were representatives from the Washington State Energ: Office: Energy Facility Site Evaluation Council: Department of Social and Health Services. which participated in the inspections leading to the disposal site shutdown: the Washington State Patrol, which also inspected the trucks; and the University of Washington radiolugy department. The univer. sity is the largest generator of low-level waste in the State of Washington but will be able to store its own wastes until November 6, according to Peterson.

\section{State Inspections, Chockpoints}

When trucks carrying nuclear works begin rolling toward the Hanford site again, they will have to enter the state at one of two ports of entry, under new rules adopted by the state's Hazardous Materials Advisory Committee.

Captain Larry Hart of the Washington State Patrol said the regulations, which took effect October 10 on an emergency basis, will require shippers of radioactive wastes to enter the state at Spokane in eastern Washington and Kennewick, located in south central Washington near the Hanford Works.

The trucks will be inspected at those points and the drivers will be given inspection records which they must present to the Nuclear Engineering Company, operator of the Hanford disposal site.

Hart.said the state patrol is basically concerned about safety of the equipment on the trucks rather than their contents, although inspectors from the patrol will check each load with radioactive monitors.

The patrol already has trained inspectors on site at the ports of entry, he said.

The reason for adopting the rules, which will become permanent within 60 days, is to "direct traffic" - of trucks carrying radinactive loads . into the twu purts of entry, Hart said. About 90 to 95 percent of trucks bound for Han. ford now pass through those ports, he said.

Hart also said he had received a letter from the state patiol in South Carolina - home of one of the two other such disposal sites in the U.S. - asking for information on Washington's inspection program. 


\section{DOE WIILL SPEED LLIV CONTINGENCY PLAN IF CONAMERCIAL UNITS ARE SHIUT DOWN}

DOE would considcr quick implementation of a daft continiecnes plan for accepting commercial low. level wastcs (LLW') at its oun sites, cren befure fomal atioption of the plan, should siatte ations sest rict shipmints to the thrce upcinting commercial racilities, agency sources say. DOE has rinied up its timetable for considering the droft plon and is heing pressured infoimally by N'RC lu conplete consideration of the continecncy plan, in light of actions or flurcats of actions in the threc states with comblncriatly aperating low.level waste repositories.

The state of Washington has temprarily shut down the facility at Hanford: Nevada is considering similat action egainst the $\mathcal{C}$ astly sitc; and South Carolinn is stiffoning policies on reccipt of mateial at the Bamwell site, which alrcady bans cerlain wastes and has limitcd capacity. The attions icsuli from increasing disquict about the quality and condition of transported wastes.

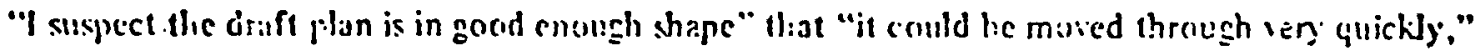
should restrictions on deliveries to the coimercial facilitiss leave the wiestes without a flace to go, decording to a DOE source. The draft. about a year in the maling, was to be forwarded last weck ircm DOE's ldaho operations office io hesdquarters waste management officia!s for internal rcticw. A no:mal tiueiable envisions shipment lo NRC. for review, V!en funal adoption by DOE, but solirces stress it could be put into

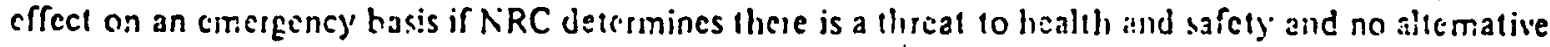
cxists to shipping the Waste to a DOE-nun site.

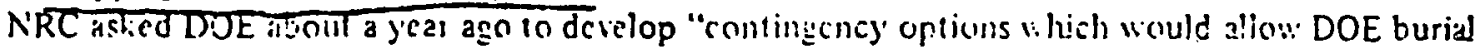
sites to accept commercial LLW," a suminary of the DOE otaft plan states. "WRC could reques: implementation of the opions in the crent it deiemines that public health and siety is credingered and no al. ecrnative exists . . untid longer range solutions can be found. . . These opious would picuide a shortierm

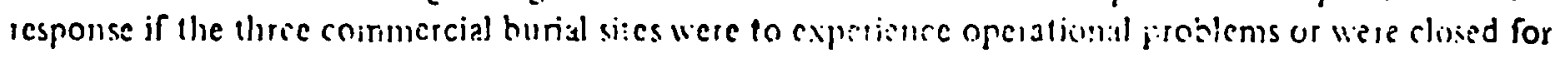
ollicr reassons."

The DOE draft contingeney pian stak:es out a tw o phinte apjirnach - phase l wesuld center on NRC efforts to find ron-DOE allematives to waste disucsal at the commencial sitcs: phasc 2 woutd be an NRC request fot DOE acceptance of the waste if phase 1 alicrmatires were not aratible. Encier ihe DOF approach,

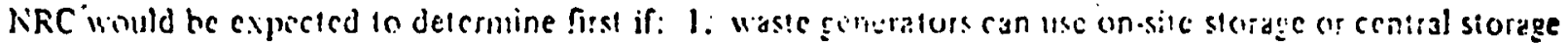

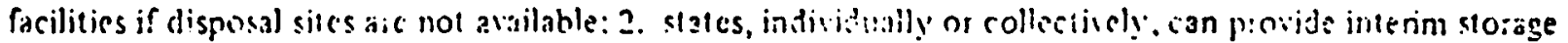

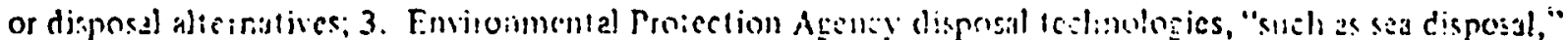

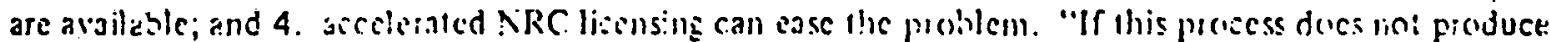

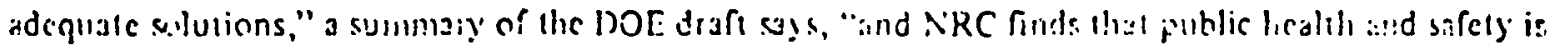

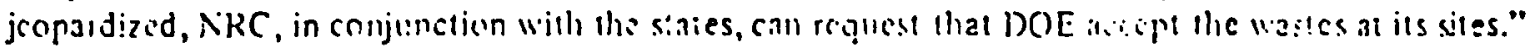

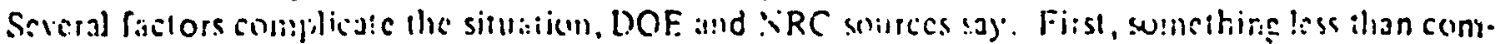

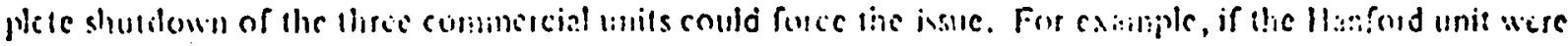

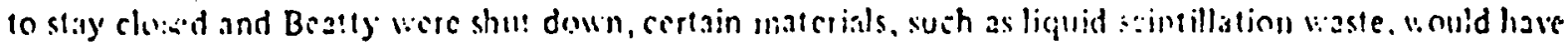

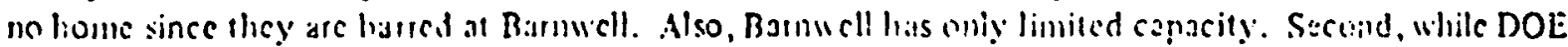

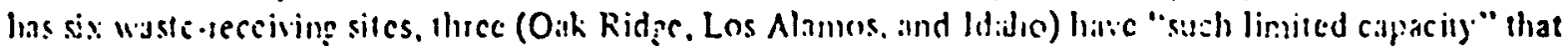

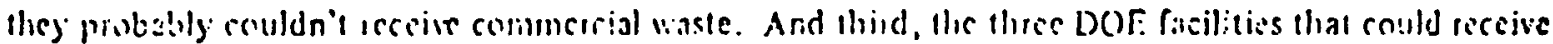

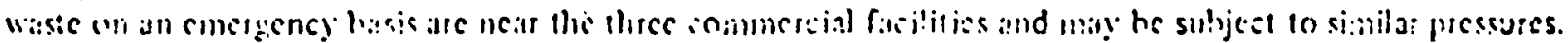

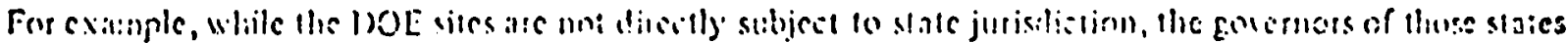

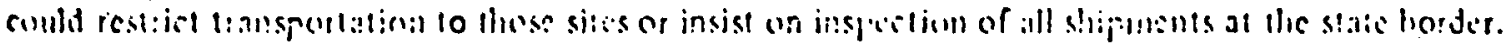

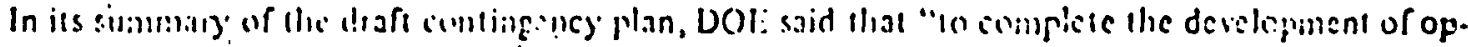
tions for handling commercial LLW"' it also is study'ing capicitics at the sites, polcntial foi craponding dis. posal space, "other prograins on the sitcs that might be advarsely" affected by substantial amounts of in. coming wastes, and the institutional problems which mirht arise in lransfersing and reinsporting the uastes." Also, DOE is studying "what requlatory and/or Iceislative procedures it would recominend may be necessary to chable DOE to takic the cominercial waste." In line with Inicrizeney Revicw Group recounmendatiuns on low-level waste nanagement, "DOE is working with tlic other involved organizations to determine the numbet, 1),pe, gencral location and disposal tecliniques recded for low.jevel wastes." 
Nov. 2, 1979

Storage capacity for low-level radioactive waste from hospitals. laboratories, and nuclear-powered generating plants virtually vanished during the week as NEVADA Covernor Robert List closed one site and SOUTH CAROLINA Covernor Richard Riley restricted that state's site to half-volume receipts. WASHINCTON Covernor Dixy Lee Ray had ordered the nation's only other low-level waste site closed earlier.

INSIDE D.O.E.

Oct. 12,1979

\section{DOE WANTS OTHERS TO ACT FIRST ON LOW-LEVEL NUCLEAR WASTE DUMP SHUTDOWNS}

A DOE draft contingency plan states that the department should not accept commercial low-level wastes at its defense facilities in the event of a shutdown of existing commercial dumps unless other hndies, sirhi as state goverriments, the Environmental Protection Agency and the Nuclear Regulatory Commission, can't solve the problem by other means, including disposal of the waste in the ocean, according to DOE sources. :

The sources said the draft contingency plan, prepared by DOE's Idaho operations office, outlines the following steps that should be taken first before NRC asks DOE to accept the wastes:

- Waste generators should determine whether they can store wastes on site or at a central storage facility;

- States should determine "individually or collectively" whether they can provide interim storage or disposal alternatives;

- EPA should determine whether disposal techniques "under its purview, such as sea disposal" can be made available;

- NRC should determine if it can accelerate licensing of any pending low-level burial site applications.

NRC asked DOE in April to develop a contingency plan for accepting the u'astes, warning that the Nuclear Engineering Co. (Neco), which operates two of the three remaining commercial low-level disposal siies, might go out of business as the result of a lawsuit brought by an Wlinois state agency against the firm (Inside DOE, 7 May, 8). Neco, which operates facilities at Beatty, Nev., and at Hanford, Wash., was sued by the Mlinois Dept. of Rublic Healih for allegedly abandoning a low-level dump site at Sheffield, Ill. The third remaining low-level site, a Chem-Nuclear facility at Barnwell, S.C., has had state limits imposed on the amount of waste it can accept, NRC sources pointed out.

The Idaho field office now is examining what regulatory procecures or legislation would be necessary for DOE to accept the commercial waste and is drawing up a number of scenarios for potential commeicial site shutdowns and the ability of DOE facilities to accept the waste, according to DOE sources. DOE is studying the capacity for low-level disposal on its sites, the potential for expanding that capacity and the institutional problems in transferring and transporting the waste, the sources said. 


\section{Nuclear. Energy}

\section{NAC, GOVERNORS SAY ALL STATES}

\section{SHOULD BE RESPONSIGLE FOR OWN WASTES}

The Nuclear Regulatory Commission and the governors of Kashington, Nevada, and South Carolina November 6 called on all states to assume responsibility for their oun low level puclear wastes, and said that medical faculties should eniure that their radioactive materials are properly packaged and shipped.

Acknowledging the shortage of low level waste disposal capacity in the U.S., NRC Chairman Joseph $M$. Hendrie said the three sites currently operating get all the wastes, and this poses an "unfair and unreasonable situation for them." On the other hand, 47 other states enjoy the benefits of nuclear medicine and research and therefore should accept responsibility for the waste generated, he said.

The three governors, Dixie Lee Ray of Washington, Robert List of Nevada, and Richard Riley of South Carolina met with Hendrie to discuss disposal problems which have resulted in the recent closing of the Hanford, Wash., site and the Beatty, Nev., site.

The Hanford site was closed Oclober 4 by Ray because of improper packaging and shipping of radioactive materials (Current Developments, Oclober 12, p. 1352). The Beatty site was closed three weeks later after radioactive barrels were found outside the fenced area. In additinn to closing the Beatty site, List also ordered the temporary suspension of the operating license of Nuclear Engineering $\mathrm{Co}$.

Barnwell now is the only site open to accept wastes. Overall, it accepts and disposes of about 85 percent of the wastes generated in the U.S. With the other two sites closed, Barnwell has refused to accept any wastes that ordinarily would go to those sites.

'Number One... Now Only One'

Commenting on Barnwell, Riley said the site has had the "unfortunate classification of being number one for a number of months and now has the classification of being the only one." He said he is going to push for each state to have its own disposal site.

"Il makes good sense for each state to be responsible for its own wastes. The technology involved in low level waste disposal is not high technology and could be handled by every state, if necessary. The reason why every state doesn't is political - it's as simple as that," he said. "No state is going to take the opportunity to develop its own site unless it is required to do so.

In an effort to reduce the unfair burden on his state, Riley said, the Chem-Nuclear license has been amended to decrease the monthly volume of low level wastes that are accepled at Barnwell. In two years the total yearly volume uill be reduced from 2.4 million cubic feet to 1 million cubic feet. In addition. he said, the state has proceeded to adjust the price for uaste from $\$ 0.16$ per cubic foot to its current price of $\mathbf{\$ 0 . 5 5}$ per cubic foot, with an eventual adjusted price of \$1 by April, 1981.
Hondrie Promises Fodoral Assistance
Hendrie told the press conlerence that he had asked Governor Ray to give serious consideration to opening Han. ford while the commission works on getting new sites developed on a regional basis.

He said the Federal Government is committed to assisting states to cnforce shipping and packaging regulations. and to train state personnel.

However, in order for the Hanford site to reopen. Ray said a permitting system for generators will have to be developed. Also. state inspections at state borders and onsite will have to be carried out, as well as proper training of state personnel, she said.

List, on the other hand, said he intends to keep the Nievada site closed, and will stand behind the requests that NRC follow-up on its commitments.

"I hope the White House, Congress, and other federal agencies will recognize the seriousness to develop a failsafe policy" for low level waste disposal, he said, adding that such a policy is possible. 
Nov. 30,1979

\section{DOE PLAN STRESSES NEVADA, RICHLAND FOR EMERGENCY NUCLEAR WASTE DISPOSAL}

A. DOE dratt contíngency plan emphasizes consideration of DOE sites at Richland, Wash., and the Nevada Test Site (NTS) for DOE storage or disposal of commercial nuclear low-level wastes if states fail to provide interim starage of new disposal sites for the wastes in time to avert a predicted mid-1980 critical shortage of commercial burial ground, DOE sources said this week.

DOE' officials, sources said, are convinced that the shortage of commercial low-level nuclear waste burial ground will become critical beginning next summer, threatening the shutdown of some eastern utilities and hospitals, which would have no place to take the low-level wastes they generate.

If states fail to take action to alleviate the problem and the Nuclear Regulatory Commission orders licensees to take wastes to federal sites, DOE's draft plan, expected to be approved by DOE next month and submitted to NRC for review in January, calls for consideration of the following options: 1. storage of wastes at DOE facilities in Richland, Wash., and/or the NTS; 2. burial of wastes at Richland and/or NTS; 3. burial of wastes only at NTS; 4 ; burial of wastes at Richland and/or NTS with limited burial of some.types of wastes at DOE's Sivannah River site; 5. storage of wastes at Richlend, NTS or Savannah River; and 6; storage of wastes ift any of DOE's six storage/disposal sites.

DOE is equipped io store and dispose of low-level nuclear wastes at Idaho National Engineoring Laboratory, Oak Ridge National Laboratory and Los Alamos Scientific Laboratory, but DOE sources said that unly sites at Richland, NTS and, to some extent, Savannah River have the capacity to handle commercial wastes.

DOE's emphasis on emergency use of its Richland and NTS sites comes at a time when Washington and Nevada governors have already closed or restricted commercial sites in their states to some incoming wastes and do not want those wastes going elsewhere in the state to DOE sites. Nevada officials have warned that the state might sue DOE if it accepts commercial waste at NTS or other DOE sites. (Inside DOE, 2 Nuv, 1). DOE's proposed policy for implementing the contingency plan, sources said, is for DOE not to overrule a governor who abjects to DOE's bringing in commercial out-of-state waste to s. DOE site in his state.

The contingency plan proposes more stringent criteria for acceptance of commercial waste and higher storage/disposal fees relative to the commercial burial ground criteria and fees. DOE would apply the more stringent criteria that it uses for its-own wastes at its sites, one source said, and this would mean that DOE would not accept any liquid low-level commercial wastës. If DOE received improperly packaged waste, the source said, the draft plan calls for DOE.to return it to the generator at his expense for proper packaging. DOE has estimated that $\$ 10 / \mathrm{cu}$. ft. of waste.would be a "ballpark figure" for the fee it would charge cornnercial users for full recovery of storage/disposal costs. This. would include $\$ 1.2 / \mathrm{cu}$. ft. of waste for a fund for perpetual care and maintenance of wastes at the DOE site.

DOE sources said states have until next year to find interim storage space or new disposal sites. The recent reopening by Gov. Dixy Lee Ray of the Hanford, Wash.; commercial low.level nuclear waste burial zrourd will postpone a critical shortage of disposal space from December to next summer, DOE officials said. The Hanford site has a capacity of about 95 acrees of potential disposal space but DOE officials do not expect the site to relieve the acute shortage for the following reasons: 1. low-level waste generators in the East, where $80 \%$ of the waste is generated, will not pay tremendous costs to ship their wastes to Hanford: 2 . the Hanford site is not geared to handle large volumes of incoming wastes; 3 . the number of-nuclear waste shipments in the U.S. would double or triple, DOE sources said, if eastern waste generators used the Hanford site, probably sparking intense public protest; 4. it is.not expected that the Beatty, Nev., commercial burial ground will reopen; and 5. South Carolina officials are beginning to restrict volume intake at the only other operating commercial burial ground, at Barnwell, S.C., as the amount of waste generated steadily increases. A critical shortage of disposal space will become evident next summer, the officials said.

DOE is drawing up a plan to help facilitate the establishment. of regional sites, at the request ot Kep. Mike MoCormack; and while the plan is not.to be completed until late next month, one source said that it probably would set up procedures whereeby DOE would assist states ir characterizing potential waste disposal sites: Said one DOE of ficial who expects states to take action and does not expect DOE will have to implement the contingency plan: "We'll probably just be whistling Dixie:" - Lynn Stevens 


\section{FUR FLIES OVER LOW-LEVEL NUCLEAR WASTE}

\section{By Ann Maclachlan}

If the low-level nuclear wastc burial ground at Hanford. Wash., is not reopened within days, "it may ncier be opered," because political pressures on Gov. ernor Dixy Lee Ray will be too great. This is the assess. ment of James McCabe, an attorncy who represents the state of Washington in the nation's capital.

Ray closed the burial ground. operated by $\mathrm{Nu}$ clear Engineering Co.. on October 6 after a series of violations of transportation and packaging regulations by nuclear waste shippers. McCabe claims it was the only reasonable action open to Ray, given public sentiment within the state, a tough election approaching next year, and the failure of the fedcral government to respond adequately to requests for help with waste inspections.

After Ray and two other governors sent an ultimatum to Washington on low-level burial in July, "we got a response within cight days of all these wonderful things [federal agencies] were going to do." said McCabe. However. most of the things - like spot inspections of packnges by NRC experts, or periodic reports on lowlevel initiatives - have yet to matcrialize. he added. "We have been horsed around on this so long we're a little gun-shy." he told The Energy Daily' on Thursday.

The Nuclear Regulatory Commission staff has written Ray to outline what it is prepared to do to encourage reoplening of the burial ground. But McCabe said this isn't enuugh: he wants letters from the Departments of Energy and Transportation as well. And he also feels it's "not asking too much" to get guarantees of federal action frum the White House (not yet forthcoming).

According to NRC's William Dircks, director of the olfice of Nuclear Materials Safety and Safeguards, the federal government is offering Ray "less than five" full. lime cxperts and an unspecilied amount of financial assistance: to lielp trinin state inspectors for the Hanfurd ficld. The fedetial personnel also would fill in with inspection and enfurcenent duties until the state people could he so qualified. Ray has indicated that if she gets adequate help from the federal government, she will be willing to reopen the Hanford site, at least for medically gencrated wastes. The problen is not so acute for low: level wastes from muclenr power or fuel cycle facilitics, sitice these usually have some room for on-site storage.
At the moment, the nation's three major commercial low-level burial grounds are pretty much in limbo. The other two active sites - at Beatty, Ner., and Barnwell, S.C. - are not available for new customers; and Beatty is shut down completely pending the outcome of a hearing November 28 , belore a state appeals panel. A waste treatment company in Texas, howevis, has agrced to take licuid medical waste.

In the long run. however, it has become clear that a national solution to low-level waste storage must be worked out. Ray and fellow governors from Nevida and South Carolins, testifying before a House subcomnutitec on Weditesday, stressed that each of the 50 states is responsible for wastes generated within its burders. However, for practical purposes, the more likely outcome will be regional disposal centers, probably including Hanford and possibly Barnwell but not linited to them.

Gaining far less enthusiasin is a proposal ty Rep. Mike McCormack (D.Wash.) to have the federal gorernment provide 12 low-level waste burial sitcs on foderal land. This proposal was turned into a study in DOE's 1980 authorization bill, but McCormack has introduced it again as a separate, more detailed bill this week. However. the gorernors testifying at Wednesday's hearing bcfore McCormack's research subcomnittee of the House Science Committee indicated they would rather see state management of radwaste disposal sites. One fear on their part is that a federal low-level waste program would be as successful as the federal high-level waste management program, which has gotten almost nowhere despite years of work.

In a related derelopment, the Departnient of Energy has stopped shipments of low-level wastes from its research and defense-related facilities to conmercial burial grounds. They will. now be shipped to existing DOE low-level burial grounds, including Los Alamos. N.M.. Idaho Falls. the Nievada Test Site. Hanford. and Savannath River. S.C. DOE had planned to ship about 450,000 cubic feet to conımercial sites during $\$ 979-$ some 18 percent of the toial amount expected at the coninercial sites this year. The agency said it hopes the new policy will help make room in the conmercial sires for medical and industrial low-level wastes.

NRC and the Federal Emergency Management Agency also are working out procedures in case of an emergency need to ship commercial nuclear waste from the site where it was producet. Federal oificials say the use of DOE burial grounds is "at the bottom of the list"; they hope to convince state governments to allow wastes to be held within the state on a short-tern basis. 
Nov.2, 1979

\section{STATES STRONGLY OPPOSE DOE TAKING LOW-LEVEL NUCLEAR WASTE AT FEDERAL SITES}

State officials strongly opposed the idez of DOE taking low-level nuclear waste on DOE reservations when that possibility was raised last week as a solution to the lack of disposal space, caused in part by the Oct. 24 shutdown of the commercial nuclear waste burial ground at Beatty, Nev.

One governor even threatened to sue DOE for such action, arguing that a DOE takeover of newlygenerated wastes would not solve safety problems, which had caused commercial site shutdowns. Shutdown of the Beatty site left only the Barnwell, S.C., burial ground open in the nation for disposal of utility and hospital-generated wastes. And it was expected that South Carolina Governor Richard Riley would announce volume restrictions for the Bamwell site Oct. 31, sources said, that would limit intake at the site by $50 \%$ over the next two years.

When it was reported that DOE and other federal officials in a special Oct. 24 meeting viere consider. ing taking the commercial wastes at DOE sites, Nevada Covernor Robert Cist sent a telegram to the White House warning Prèsident Carter that he would "vigorously oppose such action," sources said. What List : meant, one state official told Inside DOE, is that Nevada "will 80 to court" if DOE takes commercial wiaste into the Nevads Test Site or any other federal site.

Gov. List's and other governors' primary concem with DOE's accepting commercial waste, sources said, is that the action will not eliminate health and safety problems that have led to the commercial site shutdowns and will only result in the shifting of low-level nuclear waste intake from one site to another in the three states with commercial burial grounds. Commercial burial grounds are in Beatfy, Në.;.; Bamwell, S.C., and Hanford, Wash., and three of the six DOE reservations under consideration for commercial disposal are the Nevada Test Site, Savannah River, S.C., and Hanford, Wash. In the state of Washington, the commercial and federal sites are a mere one mile apart, state officials there said.

One Nevada official raised additional state concerns, saying that the states "would view this action [DOE taking commercial waste] is subverting the states' rights with respect to regulatory authority and with specific segard to the safety, health, and welfare of our [state] citizens.".

The states' concerns and warnings, said one federal source, were factors in the decision by DOE attomeys last week that DOE could only accept commercial waste on its sites in the event that NRC declared that a national health and safety emergency existed because of the unavailability of commercial disposal space.

But Gov. List is preparing, sources said, to make it clear at a Nov. 6 meeting between NRC chairman Joseph Hendrie, Dept. of Transportation officials, and Govs. Riley and Dixie Lee Ray (from Washington) that he will still oppose DOE taking the waste in an emergency situation.

List, said a Nevada official, will insist at the Nov. 6 meeting that federal officials declare safe low-level nuclear waste disposal to be a national priority and that they pledge to develop a fail-safe system for disposal. He said that $L$ ist will propose the formation of a single federal entity responsible for nuclear low-Jevel waste, perhaps a regrouping of NRC, DOT, and other officials responsible for reguiation of the waste into one agency or depariment.

Officials in the state of Washington suid that Gov. Dixie Lee Ray will fiarn NRC at the meeting that her state is considering developing its own regulatory and enforcement authority over commercial nuclear waste if NRC and DOT do not take action to upgrade packaging and shipping to ensure safe disposel.

NRC officials said that they had taxen action to upgrade regulation and enforcement of low-jevel uaste and said that they would inform the govemors of these actions at the Nov. 6 meeting. NRC, said one key official, has amended its regulations to allow NRC inspections of certain types of naste packaging, which in the past had been inspected only by DOT. Now, says the official, both NRC and DOT will inspect the packaging. NRC also has proposed a reallocation of 11 FY-80 man-years (pending approval of a request for a supplemental appropriation for that amount) for the upgrading of NRC inspection of waste packaging. NRC plans to use the money to send teams monthly to commercial sites to assist states in inspections. NRC also plans to use the money to conduct emergency inspections of any commercial araste generator at the request of a governor. 


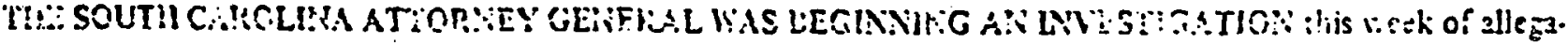

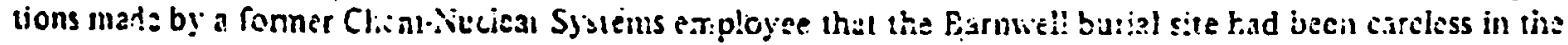
handlinz of radioactive nuaierials. The employee, Susan Lott, formerly chief sccolintant for the firm, made her allegations on a television new's broadcast. Appearing with her were a former mayor of Blackville, S.C., a tonn 10 miles from the Barnivell site, and two local farmers whlo were protesting the unsafe conditions she outlined.

Among the allegations made by Lott was that employees at the burial site - which is the nation's largest low-level waste repository - gave key's to some truckers to enable them to cpen the gates at night and did not inspect al incoming trucks. One truck - belonging to a common ca:riet - was alleged to have brought in a leaking contanilisted packige. The leak was not discovered for several dyys. During this time the trucli had been carriting common nonradioactive cargo, Lott asserted. Also, materials that had bien declared unsafe and vece to he buried at the site - such as wa!ches - veere taken by singloyees and are currently in losa' homes.

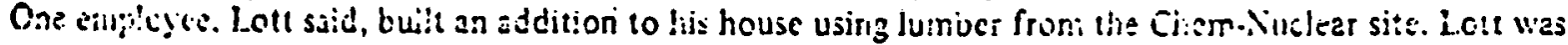
cmigis:at a: the site fruin 19:74.S.

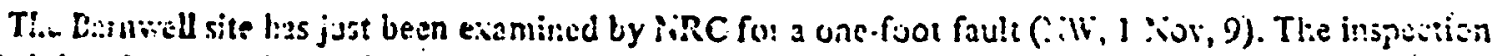
revan?

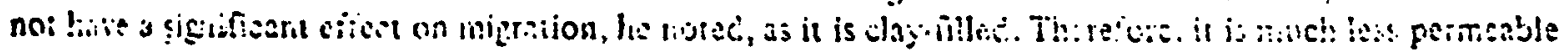

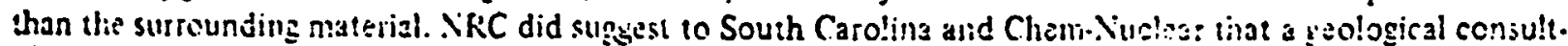
ant knowledgcible in thi a:ea also be engsged to do a report on the site. A South Carulina ofricial confirnied that a geologist liad visiied the Banivell site and that his findings had concurıed witl: those of NRC.

STATE GOVERNMENT NEWS

Dec. 1979

\section{Atomic Waste Dump to Reopen}

Washingtón Goverñof Dixy Lee Ray in mid-November announced she would reopen the Hanford low-level atomic waste dump.

Governor Ray made the annourcement after meeting with Nuclear Regulatory Commission (NRC) Chairman Joseph Hendrie on the need for improving federal enforcement of packaging and transportation standards for low-level radioactive wastes.

The action would ease problems hospitals, medical laboratories, and nuclear power stations were having in disposing of low-level radioactive wastes.

Their problems began when two of the nation's three atomic waste dumps--in Washington and Nevada-closed October 4 and 23; respectively.

Nevada Governor Robert List said the dump at Beatty will remain closed due to poor operating practices there. A hearing was set for revoking the dump's license.

South Carolina Governor Richard Riley announced the site at Barnwel! would start phasing down the total amount of waste it will accept.

The governors of the three states have emphasized that their states should not have to be repositories for all the nation's radinactive wastes. 
PENNSYLVANIA WILL UNDERT.AKE A SURVEY FOR POTENTIAL LOW-LEVEL WASTE STIES in the state. A suurce in the state Departinemt of Envirunimential Resuurces said a disposal site is necessary to replace "undependable" tacilities in Vievada. Washington and Suuch Carolina, states which have signaled their reluctonce lo aciept wiste trom ullt of their burders.

The Pennsylsunia survey. the source said. is only a preliminary step. with the bureau pressing for con. certed astion bj nurthejstern states to start handling their own low-level waste. The source nuted that it could be a niatier of yeurs fer Pentus lvania to select a tinal sile out of the candidate sites identified.

"Right mill the nurthejstern stales produce about $50 \%$ of all radioactive wastes in the cuuntry. includ.

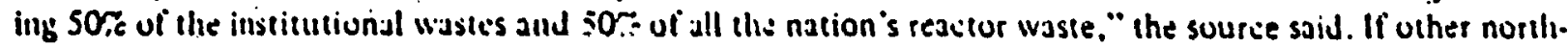
eastern states are relustunt to acictpt their responsithility. he said. Peunsyliania would probably act un its own and limit its dispusal site to communwealth waste unly. "But the best solution would be one where the statcs juined ill a cooperative venture." he suid.

\section{STATE HEADLINES (COouncil of State Governments)}

Dec. 14, 1979

\footnotetext{
Low-level radioactive waste dumping grounds in WASHINGTON and NEVADA were reopened in the past two weeks after being closed by the governors who complained of improper packaging and shipping by some electric generating stations and commercial outlets. In SOUTH CAROLINA, the state has approved a new license for the Barnwell low-level waste site but placed graduated reduction limits on the site's intake reducing by 12,000 cubic feet the amounts of material permitted in the site every three months until a level of 100,000 cubic feet per month is attained.
} 
APPENDIX D: L1st of Counties in the State Economic Areas of South Carolina 
L1st of Counties in each State Economic Area

of the State of South Carolina

SEA 1 Oconee

Pickens

SEA 2 Anderson

Greenwood

Laurens

Spartanburg

SEA 3 Cherokee

Chester

Lancaster

Union

York

SEA 4 Abbeville

Edgefield

Fairfield

McCormick

Newberry

Saluda

SEA 7 D11lon $\ldots$

Florence

Horry

Marion

Will lamsburg

Bamberg

Barnwel1

Calhoun

Clarendon

Darlington

Darlington

Hampton

Lee

Mar1boro

Orangeburg

Sumter

\section{SEA A Lexington}

Richland

SEA B AIken

SEA C Charleston

SEA D Greenville

SEA 5 Chesterfield

Kershaw 
APPENDIX E: Waste Transportation and Disposal Act 
(R499, H3350)

An Act To Amend Chapter 7 of Title 13, Code of Laws of South Carolina, 1976, Relating To Nuclear Energy, As Follows: By Adding Article 2 So As To Provide For Control Of The Transportation Of Radioactive Waste Into And Within The State, To Provide For Bonding Of Persons Transporting Such Waste And For Other Protective Safeguards, To Provide For Regulatory And Emergency Authority of The Department of Health And En. vironmental Control, To Provide For Certain Inspections And Reports, To Provide For Methods Of Enforcement Including The Service Of Legal Process, To Provide For Assessment Of Fines, Penalties and Fees And For Their Credit To The General Fund; By Adding Section 13-7.85, Relating Primarily To Article 1, Bo As To Authorize The Department Of Health And Environmental Control To Hold Public Hearings, Subpoena Witnesses, Make Findings And Establish, Assess And Pay Over Civil Penalties; By Amending Section 13-7-70, Relating To Certain Rules And Regulations of The Department Of Health And Environmental Control And To Certain Agreements With Federal Agencies, So As To Make The Section Applicable To The Transportation Of Radioactive Waste Regulated By Article 2.

Be it enacted by the General Assembly of the State of South Carolina :

South Carolina Radioactive Waste Transportation and Disposal Act

Secrion 1. Chapter 7, of Title 13 of the 1976 Code is amended by adding:

\section{"Article 2}

Control of Transportation and Disposal of Radioactive Waste

Section 13-7-110. This act shall be cited as the South Carolina Radioactive Waste Transportation and Disposal Act.

Section 13-7-120. Definitions as used in this article:

A. 'Carrier' means any person transporting radioactive wastes into or within the State for storage, disposal or delivery.

B. 'Department' means the Department of Health and Environmental Control, including personnel authorized to act on behalf of the Department.

C. 'Disposal facility' means any facility located within the State, which accepts radioactive waste for storage or disposal.

D. 'Emergency' means any condition existing outside the bounds of nuclear operating sites owned or licensed by a federal agency 
and any condition existing within or outside of the jurisdictional confines of a facility licensed by the Department arising out of the handling or the transportation of radioactive waste, as hereinabove defined, which is endangering or could reasonably be expected to endanger the health and safety of the public, or to contaminate the environment.

E. 'Generation' means the act or process of producing radinactive wastes.

F. 'Manifest' means the document used for identifying the quantity, composition, origin, and destination of radioactive waste during its transport to a disposal facility.

G. 'Operator' means every person who drives or is in actual physical control of a vehicle transporting radioactive waste.

H. 'Permit' means an authorization issued by the Department to any person involved in the generation of radioactive waste, to transport such radioactive wastes or offer such waste for transport.

I. 'Person' means any individual, public or private corporation, political subdivision, government agency, municipality, industry, partnership or any other entity whatsoever.

$\mathrm{J}$. 'Radioactive waste' means any and all equipment or materials which are radioactive or have radioactive contamination and which are required pursuant to any governing laws, regulations or licenses to be disposed of as radioactive waste and which is further defined as follows :

(1) 'High-level waste' which is defined as either irradiated nuclear reactor fuel or the portion of the material generated in the reprocessing of such irradiated fuel that contains virtually all of the fission products and most of the actinides not separated out during reprocessing.

(2) 'Transuranic waste' which is defined as waste containing more than ten nanocuries of transuranic activity per gram of material.

(3) 'Low-level radioactive waste' which is defined as all radioactive waste which contains less than ten nanocuries of transuranic activity per gram or which is free of any transuranic contaminants.

K. 'Shipper' means any person, whether a resident of South. Carolina or a non-resident (1) who transfers radioactive waste to a carrier for transportation into or within the State; (2) who transports his own radioactive waste into or within the State; or (3) who transfers radioactive waste to another person if such wastes are transported into or within the State. 
L. 'Transport' means the movement of radioactive wastes into or within South Carolina.

Section 13-7-130. This article applies to any shipper, carrier or other person who transports radioactive waste into or within this State, to any person involved in the generation of radioactive waste within this State, and to any shipper whose radioactive waste is transported into or within the State or is delivered, stored or disposed of within this State.

Section 13-7-140. A. Before any radioactive wastes may be transported into or within the State, the shipper shall:

1. Deposit and maintain with the Department a cash or corporate surety bond satisfactory to the Department in form and amount or provide evidence of liability insurance sufficient, to protect the State and the public at large from possible radiological injury or damage to any person or property due to packaging, transportation, disposal, storage or delivery of radioactive wastes.

In establishing the amount of such bond or insurance, the Department shall consider all relevant factors including the nature and quantity of radioactive waste involved; provided, that any insurance carried pursuant to Section 2210 of Title 42 of the United States Code and Part 140 of Title 10 of the Code of Federal Regulations shall be sufficient to meet the requirements of this section.

2. Comply fully with all applicable laws and administrative rules and regulations, both state and federal, regarding the packaging, transportation, storage, disposal and delivery of such wastes.

3. Certify to the Department that it will hold the State of South Carolina harmless for all claims, actions or proceedings in law or equity arising out of radiological injury or damage to persons or property occuring during the transportation of its radioactive' waste into or within the State including all costs of defending the same; provided, however, that nothing contained herein shall be construed as a waiver of the state's sovereign immunity.

4. Provide to the Department for each separate shipment of such wastes a shipping manifest which shall be signed by an authorized agent or officer of the responsible person as defined herein.

5. Provide to the Department for each separate shipment of such wastes a certification, in form satisfactory to the Department, which shall certify that the foregoing requirements have been complied with, and which may include other certifications. which the Department may find necessary to accomplish and enforce its responsibilities. 
6. Provide such other information as the Department may deem necessary for the protection of the health and safety of the public and the environment.

7. Purchase a permit authorizing the transport of radioactive wastes into or within the State.

B. The Department shall issue such permit to any shipper who shall certify that he will comply with provisions 1 through 6 of subsection $A$, and provided further that such permit shall not, in itself, be construed as authorizing a shipper to dispose of radioactive waste within the State. No additional permit shall be issued to any shipper whose permit is under suspension or revocation.

C. No permit shall be transferred, assigned or in any manner disposed of, either voluntarily or involuntarily, directly or indirectly, through transfer of control of any permit to any person, unless the Department shall, after securing full information, find the transfer is in accordance with the provisions of this act and shall give consent in writing.

Section 13-7-145. A. Any shipper who is not a resident of South Carolina and who is not registered with the Secretary of State for purposes of doing business within South Carolina, shall be subject to service of process for purposes of administering and enforcing this act by leaving copy of the Summons or any other legal paper in the hands of the Secretary of State or in his office, and such service shall be deemed sufficient service and shall have like force and effect in all respects as service upon citizens of this State found within its limits if notice of such service and a copy of the paper served are forthwith sent by certified mail to the shipper and the shipper's return receipt and an affidavit of compliance therewith are filed in the causc and submitted to the administrative agency or court from which such process or other paper issued.

Such service may also be made by delivery of a copy thereof to any such shipper outside the State, and proof of such delivery may be made by the affidavit of the person delivering such copy. Such affidavit shall be filed in the cause and submitted to the administrative agency or court from which the process or other paper issued.

B. Any carrier who is not a resident of South Carolina and who is not registered with the Secretary of State for purposes of doing business within South Carolina, shall be subject to service of process for purposes of administering and enforcing this act by leaving copy of the Summons or any other legal paper in the hands of the Secretary of State or in his office, and such service shall be deemed 
sufficient service and shall have like force and effect in all respects as service upon citizens of this State found within its limits if notice of such service and a copy of the paper served are forthwith sent by certified mail to the carrier and the carrier's return receipt and an affidavit of compliance therewith are filed in the cause and submitted to the administrative agency or court from which such process or other paper issued.

Such service may also be made by delivery of a copy thereof to any such carrier outside the State, and proof of such delivery may be made by the affidavit of the person delivering such copy. Such affidavit shall be filed in the cause and submitted to the administrative agency or court from which the process or other paper issued.

Section 13-7-150. A. After acceptance of and departure with a shipment of radioactive waste, a carrier shall immediately notify the Department of any variance, occurring after departure, from the shipper's notification of primary route and estimated date of arrival as provided in Section 13-7-160 (A) and (B).

B. The carrier shall provide to the Department a certification in form satisfactory to the Department, which shall accompany each shipment of waste materials shipped into or within the state. stating :

(1) That the shipment is properly placarded for transport and that all shipping papers required by law and administrative rules and regulations have been properly executed.

(2) That the transport vehicle has been inspected and meets the applicable requirements of the federal government and the State of South Carolina, and that all safety and operational components are in good and operative condition.

(3) That said carrier has received a copy of the shipper certification of compliance and the shipping manifest as set forth in Section 13-7-140.

(4) That said carrier shall comply fully with all applicable laws and administrative rules and regulations, both state and federal, regarding the transportation of such wastes.

C. Any shipment of such wastes to a disposal facility located within this State must be accompanied by the certification required in paragraph B above.

D. Each carrier shall provide, as deemed necessary by the Department, evidence of successful completion by its operators of operator training requirements as may be prescribed by the United States Department of Transportation for all operators transporting radioactive waste into or within thls State. 
Section 13-7-160. A. The Department shall issue interim regulations as needed for the implementation of this article immediately upon the effective date of this act, the provisions of Act 176 of 1977 notwithstanding; provided, that the regulations at a minimum Shall require that the shipper state the estimated date of arrival at the disposal facility, identify the primary route within the State, give at least seventy-two hours written notice to the Department prior to any transportation of radinartive waste into or within thie State, and establish a schedule of fees for permits, which fees shall be assessed annually.

B. Final regulations shall be promulgated by the Department within one hundred twenty days from the effective date of the article and shall be subject to the procedures set forth in Act 176 of 1977; provided that the regulations at a minimum shall include, but not be limited to, provisions for the use of signs designating radioactive material cargo; for the packing, marking, loading and handling of radioactive materials and the precautions necessary to determine whether the material which is offered for transport is in proper condition, requiring the shippers to state the estimated date of arrival at the disposal facility, to identify the primary route within the State to give at least seventy-two hours written notice to the Department prior to any transportation of radioactive waste into or within this State, and establishing a schedule of fees for permits, which fees shall be assessed annually.

In preparing its regulations, the Department of Health and Environmental Control is authorized to distinguished as to the radioactive isotope and its curie strength so as to protect the general public.

C. Rules and regulations adopted by the Department pursuant to this section may be enforced, within their respective jurisdiction, by any authorized representative of the Department, the State Department of Highways and Public Transportation and the Public Service Commission, according to mutual understandings between surh bodies of their respective responsibilities and authority.

D. The Department, in its discretion, may for any shipment allow a notification period shorter than the 72 hours required in paragraphs $A$ and $B$ of this section, if the Department determines that such notification is sztisfactory to carry out the purposes of this article. In exercising its discretion, the Department shall consider all relevant factors including the nature and quantity of the radioactive waste involved. 
E. The Department may exempt certain shipments of seventy-five cubic feet or less of radioactive waste from the advance notice provisions of this section dependent on the radioactive isotopes and curie strength in the shipment. If such is done the shipper must provide, nevertheless, the required certification pursuant to section 13-7-140 (A) (5).

Section 13-7-170. A. Owners and operators of disposal facilities shall permanently record, and report to the Department within twentyfour hours after discovery, any and all conditions in violation of the requirements of this act discovered as a result of inspections required by any license under which the facility is operated.

B. No owner or operator of a disposal facility located within this State shall accept radioactive waste for disposal unless the shipper of surh waste has a valid permit issued pursuant to Section 13-7-140 (A) of this article.

Section 13-7-180. A. Notwithstanding any other provision of law, any person violating the provisions of this article, except as provided below for radiological violations, shall be assessed a civil penalty of up to one thousand dollars for each such violation; provided, that should the Department determine that a series of such violatlons has occurred the Department shall suspend or revoke such person's permit for any time period determined to be proper, such period to be in the discretion of the Department but in any event, not to exceed twelve months.

In the case of a radiological violation, defined as any radiation level in excess of limits set forth in all applicable laws, rules and regulations, any shipper or carrier shall be assessed a civil penalty of not less than one thousand nor more than five thousand dollars, in the discretion of the Department, and such person, if a shipper, shall lose his permit for not less than thirty days, and until such further time as the shipper demonstrates to the Department's satisfaction that adequate measures have been taken to insure that such violations will not reoccur.

If a second radiological violation occurs within a period of twelve months the shipper or carrier shall be assessed a civil penalty of not less than five thousand nor more than twenty-five thousand dollars, in the discretion of the Department, and such person if a shipper shall have its permit revoked for a period in the discretion of the Department of up to one year and until such further time as the shipper has shown to the Department's satisfaction that adequate 
measures have been taken to insure that such violations will not reoccur.

B. Any person to whom an order issued under this article is directed, shall comply therewith immediately, but on application to the Department, within twenty days after the date of the order, shall be afforded a hearing within thirty days of such application. Any hearings held pursuant to this section shall be held pursuant to the procedures set forth in Act 176 of 1977, except that where the provisions of this article are in conflict with the provisions of Act 176 of 1977, this article shall control.

C. Any fines or penalties set forth in this article are in addition to any others provided by statutes, rules or regulations.

D. In assessing a fine, penalty, or suspending or revoking a permit, the Department shall consider but not be limited to, the following factors:

1. The degree of harm to the public health or safety which has resulted or might result from such violations;

2. The degree of exceedence of a radiation level as set forth in applicable law and regulation;

3. The duration of the violation; and

4. The prior record of the violator with regard to law and regulation governing the transportation of radioactive waste.

Section 13-7-190. A. The monies obtained from the levying of fines, penalties or fees under this article shall accrue to the general fund of the State.

B. The funds received from the purchase of permits shall be sufficient to administer and enforce the permitting provisions of this article.

Sertion 13-7-200. Whenever the Department finds that an emergency, as hereinabove defined, exists requiring immediate action to protect the public health, and safety the Department may, without notice or hearing, issue an order reciting the existence of such emergency and requiring that such action be taken as is necessary to meet the emergency. Notwithstanding any other provision of law, such order shall be effective immediately.

Any person to whom such order is directed shall comply therewith immediately, but on application to the Department shall be afforded a hearing within thirty days. On the basis of such hearing, the emergency order shall be continued, modified or revoked within thirty days after such hearing." 
Department authorized to hold public hearings, etc.

Secrion 2. The 1976 Code is amended in Title 13, Chapter 7, Article 1 by adding:

"Section 13-7-85. A. The Department is authorized to hold public hearings, compel attendance of witnesses, make findings of fact and determinations and to assess civil penalties. The Department by rule or regulation shall fix a schedule of reasonable fines and civil penalties relating to violations of the provisions of this article or any rule or regulation, license or license condition, permit or permit condition, temporary or permanent order, or final determination of the department and any person violating any of the provisions of this article, or any rule or regulation, license or license condition, permit or permit condition, temporary or permanent order, or final determination of the department shall be subject to said schedule of fines and civil penalties; provided, that the maximum penalty for any violation shall not exceed twenty-five thousand dollars.

Provided, that the provisions of Act 176 of 1977 notwithstanding, the Department shall issue an interim schedule of reasonable fines and civil penalties which shall remain in force and effect until such time as the Department issues final rules and regulations pursuant to the provisions of Act 176 of 1977.

Each day of noncompliance with any rule or regulation, license or license condition, permit or permit condition, temporary or permanent order, as final determination of the Department shall constitute a separate violation.

B. In assessing a fine or penalty, or suspending or revoking a permit, the Department shall consider, but not be limited to, the following factors:

1. The degree of harm to the public health or safety which has resulted or might result from such violations;

2. The degree of exceedence of a radiation level as set forth in applicable law and regulation;

3. The duration of the violation; and

4. Any prior violations of statutes, rules, orders, regulations, license or license condition, permit or permit condition.

C. Any person to whom an order issued under this article is directed, shall comply therewith immediately, but on application to the Department, within twenty days after the date of the order, shall be afforded a hearing within thirty days of such application. Any hearings held pursuant to this section shall be held pursuant to the pro- 
cedures set forth in Act 176 of 1977, except that where the provisions of this article are in conflict with the provisions of Act 176 of 1977, this article shall control.

$D$. The monies obtained from the levying of fines, penalties or fees under this article shall accrue to the general fund of the State."

\section{Applicability}

SECTION 3. The 1976 Code is amended by adding at the end of subsection (1) of Section 13-7-70 the following:

"Nothing in this section shall be deemed applicable to the transportation of radioactive waste which is regulated by Article 2 of this chapter."

\section{Severability clause}

SeCtron 4. The General Assembly hereby declares that each of the sections and provisions of this act are severable, and in the event that any one or more of such sections are declared unconstitutional or invalid, the remaining sections and provisions of this act shall remain in effect.

\section{Time effective}

Section 5. This act shall take effect upon approval by the Governor.

In the Senate House the 21st day of May

In the Year of Our Lord One Thousand Nine Hundred and Eighty.

\section{Nancy Stevenson, \\ President of the Senate.}

\section{Rex L. Carter,}

Speaker of the House of Representatives.

Approved the 26th day of May, 1980.

\section{RICHARD W. RILEY,}

Governor.

Printer's No. 142-S. 
APPENDIX F: Regulations for Radioactive Materials 
RHA 3.11 SECURITY AND FIRE PROTECTION OF STORED RADIOACTIVE MATERIAL.

3.11.1 Radioactive material shall be secured against unauthorized removal from places of storage and shall be provided with reasonable protection against loss, leakage, or dispersion by the effects of fire or by water, hose streams or by other means used to fight fire.

3.11.2 Sources of Radiation in an unrestricted area and not in storage shall be tended under the constant surveillance and immediate control of the licensee.

RHA 3.12. WASTE DISPOSAL. GENERAL REQUIREMENT.

3.12.1 Except as provided in 3.12.2, no 1 icensee shall dispose of any radioactive material except:

3.12.1.1 By transfer to an authorized recipient as provided in RHA 2.17.

3.12.1.2 As authorized pursuant to RHA 3.5, RHA 3.13. 
3.12.2 Any person may apply to the Department for approval of proposed procedures to dispose of radioactive material in a manner not otherwise authorized in this Part. Each application shall include a description of the radioactive material, including the quantities and kinds of radioactive material and the levels of radioactivity involved, and the proposed manner and conditions of disposal. The application, where appropriate, should also include an analys is and evaluation of pertinent information as to the nature of the environment, including topographical, geological, meteorological, and hydrological characteristics; usage of ground and surface waters in the general area; the nature and location of other potentially affected facilities; and procedures to be observed to minimize the risk of unexpected or hazardous exposures. The Department will not approve any application for a license to receive radioactive material from other persons for disposal on land not owned by a state or the federal government.

RHA 3.13 DISPOSAL BY RELEASE INTO SANITARY SEWER SYSTEMS. NO licensee shall discharge radioactive material into a sanitary sewer system unless:

3.13.1 It is readily soluble or dispersible in water; and

3.13.2 The quantity of any radioactive material released into the system by the licensee in any one day does not exceed the larger of:

\subsubsection{The quantity which, if diluted by the average daily quantity of sewage released into the sewer by the licensee, will result in an average concentration not greater than the limits speci- fied in RHA 3.27, Appendix A, Table I, Column 2; or}

3.13.2.2 Ten times the quantity of such material specified in RHA 3.22, Appendix B; and

3.13.3 The quantity of any radioactive material released in any month, if diluted by the average monthly quantity of water released by the licensee, will not result in an average concentration exceeding the limits specified in RHA 3.21, Appendix A, Table I, Column 2; and 
3.13.4 The gross quantity of radioactive material released into the sewer system by the licensee does not exceed one curie per year.

3.13.5 This regulation does not authorize disposal by septic tank and/or cesspool type sewage systems.

3.13.6 Excreta, blood and blood plasma from individuals undergoing medical diagnosis or therapy with radioactive material shall be exempt from any limitations contained in this regulation (RHA 3.13), provided that, the licensee provides for appropriate radiological monitoring whenever any waste line in the licensee's installation which may carry such excreta, blood or blood plasma is opened.

RHA 3.14 PROCEDURES FOR OPENING PACKAGES.

3.14.1 Each licensee shall establish and maintain procedures for safely opening packages in which licensed material is received, and shall assure that such procedures are followed and due consideration is given to special instructions for the type of package being opened. Such procedures shall include' sufficient surveys and tests of the external surfaces of the package to insure that: leakage has not occurred.

3.14.2 Results of package surveys and tests shall be recorded and maintained for inspection by the Department.

RHA 3.15 TREATMENT OR DISPOSAL BY INCINERATION. No 1 icensee shall. dispose of radioactive material by incineration or prepare it

by incineration for disposal except as specifically approved

by the Department.

RHA 3.16 RECORDS.

3.16.1 Each licensee shall maintain accurate and complete written records showing:

3.16.1.1 The results of each required survey and leak test.

3.16.1.2 Each receipt, transfer, and disposal of radioactive material.

3.16.1.3 Radiation exposures of all individuals for whom personnel monitoring is required under RHA 3.6. Exposure records shall be kept on Department Form SC-RHA-40 or a clear and legible record containing all the information required on said form and shall be for periods of time not exceeding one calendar quarter. 
APPENDIX G: Interim Regulations for the Transportation of Radioactive Waste Into or Within South Carolina 


\section{South Carolina Department of Health \\ And Environmental Control}

\section{INIERTM REGULATIONS FOR THE TRANSPORTATION \\ OF RADIOACTTVE WASTE INTO OR \\ WITHIN SOUTH CAROLINA}

Approved by the South Carolina

Board of Health and'Environmental control

May 26, 1980

Promulgated pursuant to Act No. 499 of 1980, The South Carolina Radloact1ve Waste Transportation and Disposal Act, Amending Art. 13-7-10 et seq. Of the 1976 Code of Laws. 
1. SOOPE

1.1 These regulations shall apply to all persons who ship or transport radloactive waste as herein defined into or within the State of South Carolina, the provisions of S. C. Regulation 61-63 of the 1976 Code of Laws, paragraph RHA 2.22 notwlthstanding.

i.2 These regulations shall be effective until the effective date of such final regulations as may be promulgated by the Department.

1.3 All persons subject to the provisions of this regulation shall comply with applicable provisions of 49 CFR Parts 171 - 179, 49 CFR Parts 386 - 399, 10 CFR Part 71, and S. C. Regulation 61-63 of the 1976 Code of Laws Insofar as they relate to the packaging of radioactive materfal; marking and labeling of packages, loading and storage of packages, placarding of the transportation vehicles, and monltoring and reporting requirements.

2. DEFINITIONS

2.1 "Department" means the Department of Health and Environmental Control, including personnel authorized to act on behalf of the Department.

2.2 "Disposal facllity" means any facility located within the State which accepts radloactive waste for storage or disposal.

2.3 "Generation" means the act or process of producing radioactive wastes.

2.4 "Radloactive waste" means any and all equipment or materlals which are radioactive or have radioactive contamination and which are required pursuant to any governing laws, regulat1ons, 
or Ifeenses to be disposed of as radloactive waste and which is further defined as follows:

2.4.I "High-level waste" is defined as either irradiated nuclear reactor fuel or the portion of the material generated in the reprocessing of such irradiated fuel that contains virtually all of the fission products and most of the actinides not separated out during reprocessing.

2.4.2 "Transuranic waste" which 1s defined as waste containing more than ten nanocurles of transurantc activity per gram of material.

2.4.3 "Low-level radioactive waste" which is deflned as all radioactive waste which contains less than ten nanocuries of transuranic activity per gram or which is free of any transuranic contaminants.

2.5 "Person" means any Individual, public or private corporation, political subdivision, goverment agency, municipality, industry, partnership or any other legal entity whatsoever.

2.6 "Transport" means the movement of radloactive wastes into or within South Carolina.

2.7 "Operator" means every person who drives or is in actual physical control of a vehicle transporting radioactive waste. 
2.8 "Manifest" means the document used for 1dent1fying waste during 1ts transport to a disposal facillty.

2.9 "Permlt" means an authorlzation issued by the Department to any person involved in the generation of radloactive wastes, to transport such radioactive wastes or offer such waste for transport.

2.10 "Carrier" means any person transporting radloactive wastes into or within the State for storage, disposal, or delivery.

2.11 "Shipper" means any person, whether a resident of South Caroltna or a non-resident:

2.11.1 who transfers radioactive waste to a carrler for transportation into or within the State; or

2.11.2 who transports his own radioactive waste into or w1thin the State;

or

2.11.3 who transfers radioactive waste to another person If such wastes are transported into or within the State.

2.12 "Radlologlcal violation" means radioactive contamination or the emission of radiation in excess of applicable linits.

3. BONDS AND PERIITS

3.1 Any shipper who transports radioactive waste into or within the state after July 1, 1980, must flrst:

3.1.1 Provide to the Department satisfactory evidence of financial ablilty to protect the state and the public at large from possible radiological infury or damage due to packagling, transportation, disposal, storage, 
or delivery of radioactive waste.

3.1.2 Purchase a permit from the Department. Application for a permit must be submitted in writing together with the necessary fee to:

Bureau of Radiological Health

S. C. Department of Health and Environmental Control 2600 Bull Street

Columbla, South Carolina 29201

The application must include:

3.1.2.1 the company name, address, and location(s)

from which the waste w1ll be shipped;

3.1.2.2 the name, t1tle, address and phone of that

Individuas: in corporate management who is

responsible for radioactive waste shipments and disposal;

3.1.2.3 a statement that the company has current onples of the disposal site radinactive materials Iicense, the disposal site waste acceptance criterla, and 49 CFR Parts 171 - 179.

3.1.2.4 a certificate that the shipper w111 hold the State of South Carolina harmless for all clafms, actions, or proceedings in law or equity arlsing out of radiological injury or damage to persons or property occurring during the transportation of its radioactive waste into or within the state including all costs of defending the same; provided, however, that nothing contained herein shall be construed as a walver of the state's sovereign immunty. 
3.1.3 The permit fee for any shipper who w1li ship a total of 75 cublc feet or less of radicactive waste consisting of 100 curies or less total activity for disposal with the state between the date of Issuance of the permit and Secember $31,1980,15 \$ 50$. The fee for any shipper who will insp more than 75 cubic feet or more than 100 curies between ine date of issuance and December 31, 1980, 1s $\$ 500$. The fee any shipper who does not consign radioactive waste tic storage or disposal within the state between the date of 1ssuance and December 31,1980 , is $\$ 50$.

3.2 The fee for the permit so purchased will not be refunded. Any surety bond will be returmed to any shipper who notifles the Department in writing of his intention to cease shipments of radloactive waste Into or within the State after the last such shipment is accepted safely at its destination.

4. ROUTES, PRIOR NOTIFICATION, AND CERTIFICATION

4.1 Before a shipment of radloact1ve waste may be transported into or within the State, the shipper shall comply. With the following provisions:

4.1.1 Give written not1ce to the Department at least 72 hours before the expected date of the shipment except as provlded in paragraph 4.1.2. In the case of shipments consigned for disposal, this requirement may be satisfied by such other report required by rule, regulation, or pollcy, which contains the same information and which is recelved by the 
Department at least 72 hours before the est1mated time of shipment. Such notice shall consist of at least the following information:

4.1.1.1 the estimated date of arrival if the destination is withtn the State, or the estimated date of shipment if the destination is outside the State;

4.1.1.2 the route to be followed within the State;

4.1.2 For shipments consisting of 75 cubic feet or less and contalning 1 curle of radioactive material or less and which may be consigned as non-exclusive use shipments according to applicable U. S. Department of Transportation regulations, the requirement for prior notification contained in paragraph 4.1 .1 is walved. Nevertheless, such shipments must comply with all other laws, regulations, and rules.

4.2 The carrier and all drivers shall be provided with a copy of the prior notification required by paragraph 4.1 and Instructed to comply with the routes and schedule contained therein.

4.3 Each manifest used to describe a radioaetive waste shipment shall include a certiflcation properly executed by a representative of the shipper which shall include at a minimm the statement that the shipment has been inspected within 48 hours of the time of departure and that no 1tems of non-compliance with appl1cable laws, mies, or regulations were found. 
4.4 Each shipper shall provide to the Department for each shipment, a copy of the Radioactive Waste Prior Notif1cation and Manifest Form with the consignee acknowledgement properly executed.

\section{CARRIER'S CERTIFICATION}

5.1 Each carrler who transports radioactive waste into or within the State after July 1, 1980, shall provide the following certificate:

Certification is hereby made to the $S$. C. Department of Health and Enviromental Control that:

1) the shipper has provided the carrier with a copy of the shipment manifest, the certificate of compliance, and the routing instructions;

2) the shipment of radioactive waste has been properly placarded for transport according to applicable U. S. Department of Transportation regulations;

3) all shipping papers originated or reproduced by the carrier have been properly executed;

4) the transport vehtcle has been inspected according to applicable DOT regulations and within the prescribed intervals and that all safety and operational components are in good working order; 
5) all drivers who will operate the vehicle within the State are qualified to transport hazardous materlals as specified by applicable U. S. Department of Transportation regulations.

5.2 This certificate shall be typed or mechanicaliy reproduced. Iegtble mechanical reproduction of this page is acceptable. 5.3 The certificate shall:

5.3.1 be slgned by a principal, officer, partner, or employee of the carrler or lis asent; and

5.3 .2 be legibly slgned manually, by typewnter, or by other mechantcal means.

\section{PENAITIES}

6.1 Whenever the Department finds that violations of the provisions of this regulation have occurred, it may impose penalties as follows :

6.1.1 Any person who commits a radiological violation shall:

6.1.1.1 be fined not less than one thousand nor more than flve thousand dollars; and

6.1.1.2 if such person is a shipper, have his permit suspended for a period of not less than thinty days and unt1l such time as he demonstrates to the Department's satisfaction that adequate 